UNIVERSIDADE DE SÃO PAULO

FACULDADE DE FILOSOFIA, LETRAS E CIÊNCIAS HUMANAS

DEPARTAMENTO DE LETRAS CLÁSSICAS E VERNÁCULAS

PROGRAMA DE PÓS-GRADUAÇÃO EM ESTUDOS COMPARADOS DE LITERATURAS DE LÍNGUA PORTUGUESA

\title{
O JOGO ENTRE AS EFABULAÇÕES FRADIQUIANAS
}

(Versão Corrigida)

De acordo:

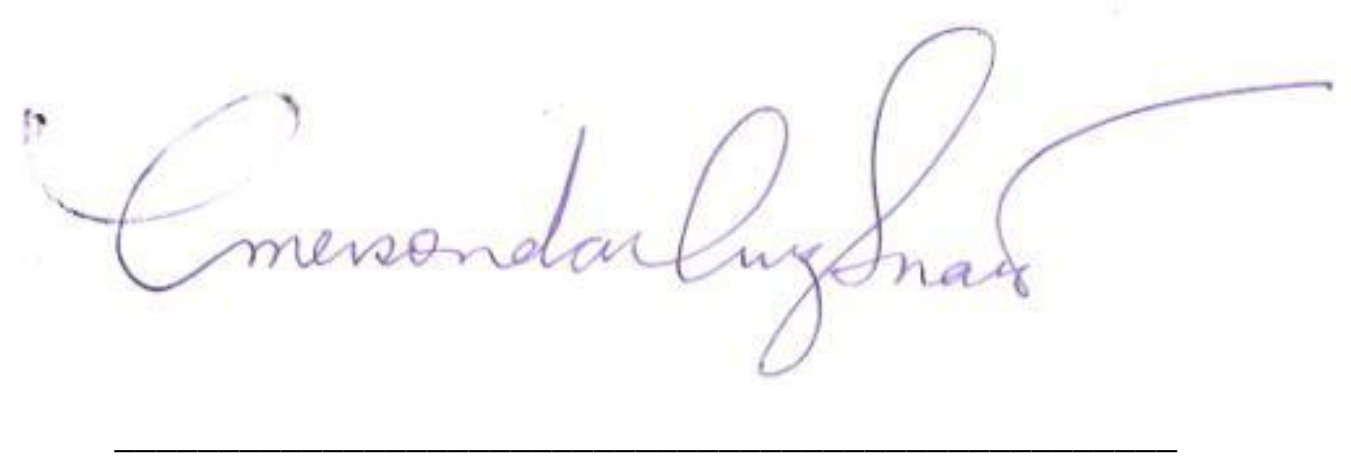

Prof. Dr. Emerson da Cruz Inácio

São Paulo 
EDUARDO GONZALES MOREIRA

\section{O JOGO ENTRE AS EFABULAÇÕES FRADIQUIANAS}

(Versão Corrigida)

Dissertação apresentada ao Programa de PósGraduação em Estudos Comparados de Literaturas de Língua Portuguesa da Faculdade de Filosofia, Letras e Ciências Humanas da Universidade de São Paulo como requisito à obtenção do título de Mestre em Letras.

Área de Estudos Comparados de Literaturas de Língua Portuguesa - DLCV - FFLCH USP.

Orientador: Prof. Dr. Emerson da Cruz Inácio

São Paulo 
Nome: MOREIRA, Eduardo Gonzales

Título: O JOGO ENTRE AS EFABULAÇÕES FRADIQUIANAS

Dissertação apresentada à Faculdade de Filosofia, Letras e Ciências Humanas da Universidade de São Paulo para obtenção do título de Mestre em Estudos Comparados de Literaturas de Língua Portuguesa

Aprovado em:

Banca Examinadora

Prof. Dr. Instituição:

Julgamento: Assinatura:

Prof. Dr. Instituição:

Julgamento: Assinatura:

Prof. Dr. Instituição:

Julgamento: Assinatura: 


\section{AGRADECIMENTOS}

A Capes, pela bolsa concedida e com isso a possibilidade da viagem de pesquisa à Lisboa, a fim de entrevistar o autor Fernando Venâncio e recolher documentos importantes.

Aos amigos do Grupo de Estudos de Literatura Comparada: Victor Palomo, Arnaldo Sobrinho, Nathália Nahas, Cesar Pontual e Sandra Salavandro. cordialidade.

Em especial ao autor Fernando Venâncio, que me recebeu em Lisboa com extrema

Aos professores da banca e aos suplentes.

Aos funcionários do DLCV. Valentim.

Aos professores Mário Lugarinho, Lilian Jacoto, Fátima Bueno, Paulo Mota, Jorge

À família e à namorada. 
Apesar de trinta séculos de Geometria me afirmarem que a linha reta é a mais curta distância entre dois pontos, se eu achasse que, para subir da porta do Hotel Universal à porta da Casa Havana, me saía mais direto e breve rodear pelo bairro de $S$. Martinho e pelos altos da Graça, declararia logo à secular geometria - que a distância mais curta entre dois pontos é uma curva vadia e delirante.

Fradique Mendes 


\section{RESUMO}

O trabalho proposto tem por objetivo estabelecer e evidenciar as pontes que unem as efabulações fradiquianas, tendo como base as obras Os Mistérios da Estrada de Sintra e A Correspondência de Fradique Mendes, de Eça de Queiroz; O Único Filho de Fradique Mendes, de Frederico de Sá Perry Vidal; Nação Crioula, de José Eduardo Agualusa eEsquemas de Fradique, de Fernando Venâncio, procurando comprovar que as efabulações são partes de um todo maior e continuo e que revelam a tentativa de, durante mais de um século, formular possíveis bibliografias para a personagem, Fradique Mendes. Pretende-se, ainda, demonstrar quais são os elementos narrativos que ligam as obras em questão, considerando para isso as intencionalidades autorais e as coerências na constituição do personagem.

Palavras-chave: Literatura Comparados, Ironia, Intertexto, Efabulação, Literaturas de Língua Portuguesa. 


\section{ABSTRACT}

This research works to establish and make evident the connections that unit Fradiques' fables, based on these chosen works: Os Mistérios da Estrada de Sintra and A Correspondência de Fradique Mendes, by Eça de Queiroz; O Único Filho de Fradique Mendes, by Frederico de Sá Perry Vidal; Nação Crioula, by José Eduardo Agualusa and Esquemas de Fradique, by Fernando Venâncio. By this way, its focus is proving that his fables are pieces of a unique and bigger entire. It's a trying of, for more than a century, formulating a biography (always eternal) of one of the most important character from Portuguese Literature, Fradique Mendes. Furthermore, to demonstrate mainly which are the narrative's elements that connect the parts, respecting certain coherencies on this character's making (also taking into consideration the different authors' intentions)

Keywords: Comparative Studies, Irony, Intertexto, Efabulação, Portuguese Literature. 
Sumário

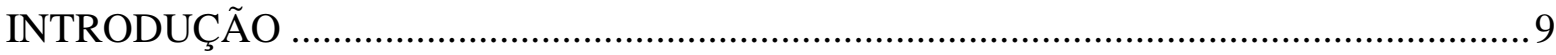

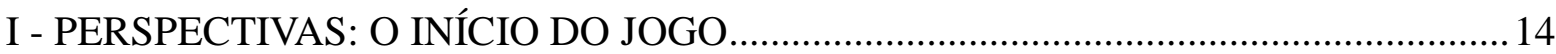

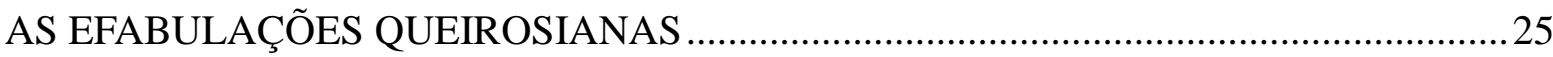

1.1 - O FRADIQUE DE “OS MISTÉRIOS”: O COADJUVANTE EXCÊNTRICO .......25

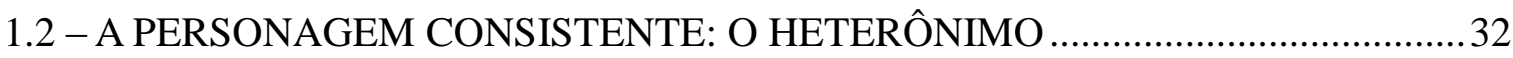

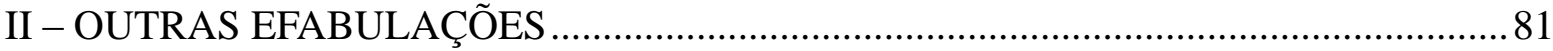

2.1- FRADIQUE DO JOVEM VIDAL: O MESTRE DA CONTRA-REVOLUÇÃO ....... 81

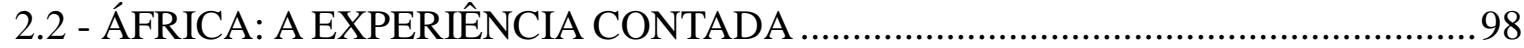

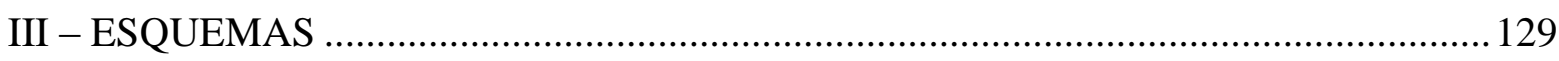

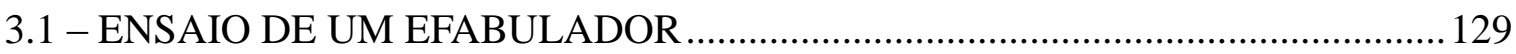

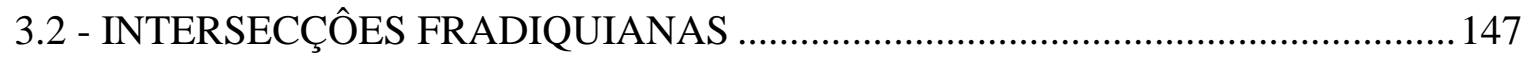

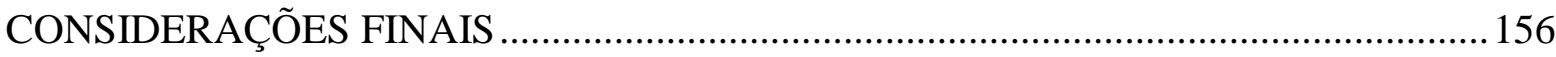

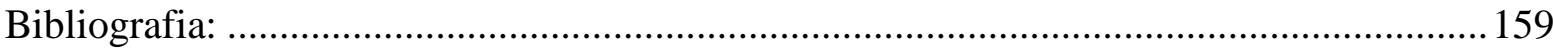

Entrevista com FERNANDO VENÂNCIO .................................................................... 164 


\section{INTRODUÇÃO}

O principal intuito da dissertação é demonstrar como se dá o processo de empréstimo da personagem Carlos Fradique Mendes, inicialmente criado como heterônimo coletivo e posteriormente trabalhado por Eça de Queiroz ${ }^{1}$. As obras do escopo são Os Esquemas de Fradique, de Fernando Venâncio, O Único Filho de Fradique Mendes, de Frederico Perry Vidal e Nação Crioula, de Eduardo Agualusa; objetivamos também verificar como essa (re)criação se articula com os elementos intrínsecos da personagem queirosiana de A Correspondência de Fradique Mendes ${ }^{2}$ e como o último efabulador, Fernando Venâncio, articula e reestrutura a biografia de Fradique criada a várias mãos, e é este autor de conduz a leitura do trabalho.

Demonstraremos como ocorrem os elementos intrínsecos, que aqui trataremos como "regras do jogo", e analisaremos duas obras em que figuram Fradique Mendes, um primeiro momento em Os Mistérios da Estrada de Sintra e, depois, quando essa personagem ganha uma biografia e vida entre os escritores da geração de 70, A Correspondência de Fradique Mendes.

Trataremos também das efabulações de Frederico Perry Vidal, em $O$ único filho de Fradique Mendes e de José Eduardo Agualusa, em Nação Crioula. Por fim traremos aquele que elabora um verdadeiro esquema de tudo o que foi feito de Fradique Mendes, em um romance com características de ensaio, Fernando Venâncio, com Esquemas de Fradique, monta um quebra cabeça que nos dá, principalmente, base para afirmar e provar a unidade narrativa que há entre todos os textos do escopo.

Mostraremos que todas as obras propostas seguem em linhas paralelas e em alguns momentos, guardadas suas devidas proporções e intencionalidades, apresentam pontos de intersecção (as coerências), em um jogo de regras definidas. Estas que, de fato, fazem com que o jogo possa ser articulado tendo como base conceitos ambivalentes: realidade e ficção, verdade e mentira, autêntico e falso, paródia e homenagem, modernidade e tradição, colônia e metrópole, centro e periferia (com atenção à condição específica do contexto português) ${ }^{3}$.

O trabalho se dividirá em capítulos. No primeiro esclareceremos qual será o olhar frente às obras, as perspectivas, que se definirão não por óticas estanque, por mais que cada obra apresente

\footnotetext{
${ }^{1}$ Em boa e chã verdade, pouquíssimo se sabe acerca do breve período durante o qual foi criado o heterônimo coletivo Carlos Fradique Mendes, a não ser que esse fato terá ocorrido entre os fins de 1868 ou começos de 1869 e Maio ou Junho de 1869. (SERRÃO. 1985. pág. 197)

${ }^{2}$ Inclui-se aqui a Última carta de Fradique Mendes, que compõe a obra Últimas Páginas, publicada em 1912.

${ }^{3}$ Com exceção de um período de algumas décadas nos séculos XV - XVI, Portugal foi durante todo o longo ciclo colonial um país semiperiférico, atuando como correia de transmissão entre as colônias e as e os grandes centros de acumulação, sobretudo a Inglaterra a partir do século XVIII, e este fato teve uma importância decisiva para todos os povos envolvidos na relação colonial, uma importância que, de resto, se manteve mesmo depois de essa relação ter terminado e até aos nossos dias. (SANTOS. 2008. pág. 148)
} 
peculiaridades temos por objetivo discutir como essa personagem é constituída como um todo e, a nosso ver, se promove como uma personagem de uma só biografia, embora múltiplo nas criações, intencionalidades e universos.

As efabulações se apresentam como fios entrelaçados de uma única corda (biografia). De certo que há o Fradique de Eça, o Fradique de Agualusa, o de Vidal e o de Venâncio, mas todos eles podem ser lidos em um todo narrativo, ou biográfico - o que mostra principalmente Venâncio com seu esquema, que de fato norteia a nossa leitura.

Todos eles constituem Fradique Mendes, podemos falar aqui sobre as frações: a fração queirosiana, a fração agualusiana, a fração venanciana, e assim por diante. Há, sem dúvida, e é o que tentaremos mostrar - respeitando as nuances e peculiaridades de cada "parte" dessa personagem - uma linha fradiquiana, e que só é montada de maneira uniforme e coesa porque foram respeitadas as regras para que esse jogo pudesse continuar por várias efabulações. E que ainda possa continuar.

Será no capitulo primeiro - Perspectivas - que essas regras serão discutidas. Definidas por Eça, e que no decorrer do processo (in)finito de construção dessa personagem são retomadas e respeitadas, até o momento em que Fernando Venâncio recoloca claramente essas regras discutindo até mesmo o processo de criação das frações fradiquianas.

Todas as frações fradiquianas carregam em si uma excentricidade e um deslocamento da vida social burguesa do final do século XIX. Desde o Fradique coadjuvante em O Mistério da Estrada de Sintra, até o Fradique rememorado em Esquemas de Fradique, de Venâncio. Todos eles têm um olhar aguçado, crítico, e até ácido frente à realidade portuguesa e frente ao processo de colonização (principalmente em Agualusa). Há nessas frações também o humor e a ironia típicos do estilo eciano.

O trabalho se dividirá em três capítulos: "Perspectivas: O Início do Jogo (I)"; em que demonstraremos qual será o olhar para com as obras escolhidas, principalmente levantando hipóteses de regras que os autores que efabulam Fradique Mendes seguem para que haja um jogo coerente e principalmente para que se prove, ao final do trabalho, que estes trabalham "trechos" de uma mesma linha, ou seja, partes de um todo narrativo maior chamado Fradique Mendes. Neste capítulo também analisaremos como se dá a formulação do Fradique inicial, em Os Mistérios e em A Correspondência.

Entendemos que uma das principais efabulações, pelo seu caráter de união e crítica sobre aquilo que foi feito sobre Fradique Mendes, é a obra de Fernando Venâncio intitulada Esquemas de Fradique. Nela o autor, ao produzir um romance com características ensaísticas, procura atar as pontas dessa corda fradiquiana. As obras as quais Fernando Venâncio faz menção são as tratadas no escopo.

A última obra analisada aqui será pertinentemente a venanciana, já que é ela parece provar a 
nossa hipótese de uma unidade biográfica, ou narrativa, além de trabalhar criticamente as outras obras do escopo. Venâncio cria pertinentemente um romance com características de ensaio, e nos dá o arremate para este trabalho, que seguirá em linhas também ensaísticas. Seguem em ordem cronológica: Os Mistérios da Estrada de Sintra, de Eça de Queiroz; A Correspondência de Fradique Mendes, de Eça de Queiroz; O Único Filho de Fradique Mendes, de Frederico de Sá Perry Vidal; Nação Crioula, de José Eduardo Agualusa e Esquemas de Fradique, de Fernando Venâncio.

No subcapítulo 1.1, intitulado Fradique de Os Mistérios: o coadjuvante excêntrico, pretendemos mostrar como se dá a aparição de Fradique Mendes em um texto ficcional, na verdade a apresentação dessa personagem. Aqui a personagem começa a ser conhecida do público leitor. Pretendemos mostrar que nessa personagem já há traços com potencial para uma criação biográfica e, além disso, uma singularidade na personalidade da personagem, já em grau elevado de ironia, perspicácia, excentricidade, potencial lírico (poeta), sede pela descoberta (desbravador), entre outras.

As inclinações satanistas desta fração são aqui evidenciadas, para depois citar seu conjunto de poesias em Correspondência (Lapidárias). Tendo em vista a época de produção e possíveis intencionalidades, pode haver algumas diferenças entre esta fração e as demais (principalmente comparada com a fração agualusiana), mas nada que quebre uma linha coerente geral e essencial da personagem.

No item 1.2, intitulado A Personagem Consistente: o heterônimo, pretendemos mostrar como essa personagem definitivamente ganha vida, ou seja, uma biografia, contada, ficcionalmente, pelo seu principal criador, Eça de Queiroz. Torna-se ficcionalmente amigo deste e dos outros importantes escritores da geração de 70, saindo da literatura e se transfigurando como um destes autores. Pretendemos demonstrar que é neste momento que Fradique Mendes recebe suas características essenciais, que foram o resultado daquele potencial de Os Mistérios e é aquilo que será trabalhado pelos efabuladores subsequentes (respeitando novamente algumas nuances). Podemos dizer que é definitivamente na Correspondência que se faz a "forma" de Fradique e se cria um princípio, uma base para futuras efabulações. Eça apresenta uma personagem que, a partir desse momento, fica a mercê de conjecturas, elabora-se uma biografia, ou melhor, parte dela, para um jogo literário contínuo e (in)finito. Eça proporciona no início do jogo nessa obra.

No subcapítulo intitulado Fradique do Jovem Vidal: O Mestre da Contra-Revolução (2.1) pretendemos trazer a análise de uma obra que não apresenta de fato uma maturidade literária, como afirma o crítico Fernando Venâncio, mas se trata de uma primeira tentativa de continuidade desse jogo. Cria-se um descendente do "homem do século" trabalhado por Eça. Nessa obra o "lendário" Fradique é lembrado a todo o momento pelo herdeiro. E seu único descendente (até aqui) traz 
características do pai. Tais características são trabalhadas e também tudo aquilo que se relaciona com a biografia de Fradique Mendes (por exemplo, a cena em que Palidorff - filho - destrói os espólios de Fradique - que vão reaparecer Venâncio), como peças de um quebra cabeças.

Em 2.2, intitulado África: a experiência contada, apresentaremos uma análise da obra Nação Crioula, de José Eduardo Agualusa. Mostrando de que maneira essa personagem será retomada dentro do gênero epistolar. Embora o gênero assumido pelo autor seja o romance (e faremos um estudo também sobre essa estrutura epistolar com um enredo romanesco típico), o que nos é apresentado é um conjunto de cartas. Demonstraremos que essa obra é uma das efabulações que mais traduz um período histórico e um contexto sociopolítico (relação colônia - metrópole em África - Tráfico negreiro e a relação África - Brasil, Brasil - Portugal, Portugal - África). E ao contrapormos as duas frações fradiquianas (Queiroz e Agualusa) demonstraremos (dentro das especificidades de cada obra) como a fração agualusiana é empírica (experiências) e a fração queirosiana tende mais a filosofia e a política.

O Capítulo 3 - Esquemas - traz inicialmente aquele efabulador que para nós é o principal deles, não considerando o criador de Fradique. Venâncio é quem coloca em prática a hipótese aqui levantada - a composição de uma unidade narrativa, biográfica, em Fradique Mendes. Venâncio cria um romance com características ensaísticas, trabalhando explicitamente as intertextualidades entre as frações.

Fernando Venâncio parece dar os laços que unem as efabulações, as aparas são recortadas (readaptações na linha biográfica - 3.1). O autor faz com que uma rede densa seja construída com a linha fradiquiana. Monta um quebra cabeça, às vezes ajustando as peças e para isso, o que fica claro, houve a necessidade de vasta pesquisa sobre as efabulações e sobre o processo criativo na construção de Fradique Mendes.

Esquemas, diferente das outras narrativas, traz à tona a discussão do papel do efabulador. Enquanto os outros simulam a realidade na ficção, Venâncio relativiza a própria realidade. Cria a partir de Agualusa (vertente de Ana Olímpia - Dr. Cristiano) e a partir de Vidal (vertente da Madame Lobriska - Leonor) uma realidade que não é a ficcional, nem a real, pode ser algo paralelo a tudo isso, pois tão real e imaginário são os descendentes de Fradique Mendes.

O autor de Esquemas traz também um panorama do Portugal contemporâneo - a narrativa se passa próxima à data de comemoração dos 25 anos da Revolução dos Cravos. Além disso, vamos demonstrar como Venâncio tenta fazer com que um filho da pátria portuguesa faça as pazes com sua terra. Venâncio parece transbordar a figura fradiquiana e nela transplantar elementos ainda não vistos, fazendo com que uma nova visão de toda a trajetória fradiquiana se refaça - de Flâneur a herói nacional.

Por fim, em 3.2, buscamos, ou reafirmamos fatos, elementos, cenas que provem as 
intersecções (intertextualidades) entre as frações fradiquianas, que comprovem a coerência entre todas as efabulações, não de maneira estanque em relação às obras, mas de maneira comparativa. Por exemplo, a constante ironia e excentricidade, a visão que é estabelecida em relação à mulher e sua importância nas relações fradiquianas, o olhar fradiquiano frente o novo, e o que essa personagem representa para os séculos em que sobrevive (novo X velho) para todas as efabulações, entre outras questões importantes.

Portanto, o trabalho aqui exposto intenta traçar uma trajetória de um personagem que não pertence a somente um autor, personagem que tem o poder de flanar pelos textos e pelo imaginário português, ativo em sua posição crítica, mas a mercê de outras penas. 


\section{I - PERSPECTIVAS: O INÍCIO DO JOGO}

A palavra "jogo" aqui utilizada é coerente no sentido de que as efabulações fradiquianas seguem algumas regras em sua produção, entendidas como elementos que podem e devem ser seguidos para que haja a construção de uma personagem coerente. Primeiramente há a regra de criação pautada na linearidade do tempo. O jogo é constituído com base em uma linearidade temporal. Isso prova também não Fradiques paralelos, e em realidades paralelas, mas sim um mesmo Fradique dentro de um tempo determinado, uma mesma biografia.

Inicialmente Fradique nos é apresentado no romance Os Mistérios da Estrada de Sintra, publicado em folhetim no Diário de Notícias, de 24 de Julho a 27 de Setembro de 1870, recebendo a primeira versão em livro em 1884. Aqui o personagem vem à tona como coadjuvante excêntrico, por meio do gênero romance.

Até esse momento Fradique reverbera em um tempo virtual e não definido, mas a partir do momento que essa personagem é trabalhada exclusivamente por Eça de Queiroz em $A$ Correspondência de Fradique Mendes, ganha corpo dentro de um tempo e espaço delimitados, perceptível pelo endereçamento das cartas.

A partir daí, todo e qualquer efabulador futuro teria que se adequar a esta primeira configuração. A partir do momento em que Eça determina os discursos de Fradique em cartas (não há dias, mas há meses e anos), seria incoerente por parte dos outros efabuladores a criação de algum outro documento que deslocasse Fradique de um contexto que não fosse consistente com determinadas lacunas temporais.

Explicamos: se Eça, criador de Fradique no gênero epistolar, determina que Fradique deva estar em Paris em junho de 1877, seria incoerente (quebrando uma regra do jogo) que José Eduardo Agualusa o colocasse no Rio de Janeiro neste mesmo mês.

Contudo, vemos que há, certamente, em todas as efabulações propostas, o respeito às lacunas temporais deixadas por Eça de Queiroz (e esse jogo é descrito e trabalhado em Esquemas de Fradique - quando Martinho inicia sua investigação sobre os paradeiros desconhecidos de Fradique, tem como base datas para provar a veracidade das informações).

Passando do romance de Eduardo Agualusa ao de Fernando Venâncio há elementos que nos chamam a atenção: inicialmente há o abandono do gênero epistolar e a retomada do gênero romanesco (mesmo que o gênero indicado em Agualusa seja o Romance - e as cartas são realmente trabalhadas como capítulos desse gênero).

Fradique é retomado pela lembrança de um de seus descendentes, mas, não obstante a isso, há algumas indicações bastante pontuais (temporalmente) quando o protagonista do romance 
(primeira pessoa), o jornalista Martinho, encaminha-se no processo de pesquisa sobre o "grande homem do século XIX", ele encontra documentos que demonstram que Fradique teria se encontrado, em 1876, com uma personalidade do século, Maria Letizia Rattazzi. Vemos então que datas são de fato importantes para esse processo investigativo:

A conversa entre Fradique e Maria Letizia Ratazzi sobre Portugal, no capítulo 4, reproduz parcialmente o diálogo que, no prefácio à edição francesa de Un Divorce. Drame d'Antonio Ennês (Paris, 1878), Mme Ratazzi põe na própria boca e na de um interlocutor imaginário. (VENÂNCIO. 1999. pág. 232).

Nesta última obra o autor intercala esse encontro com Mme Ratazzi com algumas informações extraídas de A Correspondência de Fradique Mendes:

Outra descoberta minha - mas o dr. Fradique logo verá nisso extrapolações - foi a de que os contatos parisienses do bon-vivant com a princesa Ratazzi não se ficaram pelos culturais. Vendo bem, nem admira. Ambos eram mundanos, numa cidade mundana, e ambos cosmopolitas, numa cidade xenófoba. A princesa regressava, nesses começos de Verão de 1876, da segunda visita a Portugal, e aparecera decotadíssima, na soirée que o embaixador oferecia, antes dos banhos diplomáticos. Fradique, que fizera já as malas para Lisboa, rumo a Angola, onde veria Ana Olímpia, estava, ele também, na recepção, e foi a embaixatriz em pessoa quem os apresentou. Em boa hora, pois Maria Letizia logo se sentiu disposta a distrair Carlos desses enervantes dias da espera. (VENÂNCIO. 1999. págs. 24 e 25).

Uma linha do tempo que, determinada inicialmente pelo gênero epistolar, se constitui, se entrelaça e se desdobra pelos textos fradiquianos. A Correspondência de Fradique Mendes como mola propulsora e matriz, Agualusa como fio entrelaçador e continuidade, Vital com sua fração em um nó bem apertado e Venâncio, com uma rede forte, abraça todo esse processo narrativo, onde nada escapa e tudo é devidamente preenchido e coerentemente constituído.

Em outra vertente, todos os romances são certamente críticos, cada um a sua maneira e se utilizam de uma personagem que se encaixa perfeitamente em uma visão contrária ao senso comum. Fradique Mendes não escapou a nenhuma dessas regras, e foi, como será comprovado, construído como esfera perfeita e colocado em jogo, como um toque de bola e em cada lance, jogador por jogador faz suas embaixadas e cada um marca o seu gol.

Apresenta-nos Fonseca:

Agualusa afirma com frequência que literatura é jogo, teatro, brincadeira, não devendo ser levada a sério, fora o pacto inventivo que propõe ao leitor. Mas é interessante observar que o jovem escritor angolano tem provocado muita ira em muitos críticos, exatamente porque, aparentemente só brincando, assume uma atitude iconoclasta e irreverente com relação às verdades instituídas. (FONSECA. 2001. pág. 256) 
Cada autor, dentro de suas propostas, trata de um Fradique sempre crítico, se não por cartas, de maneira rememorada, e se há algum descendente, parece que este recebe como carga genética o poder de crítica. São críticos e excêntricos. Fradique é instrumento para tocar as feridas sociais, como será visto nos capítulos em que trataremos especificamente de cada efabulação.

Excentricidade e instabilidade já definem outro elemento para essa construção coerente. E essas características fazem com que certas nuances apareçam. Partiremos da primeira ocorrência da personagem, em Os Mistérios da Estrada de Sintra, até a última retomada proposta, Esquemas de Fradique. De certo que, mesmo não fazendo parte do escopo inicial, Os Mistérios se torna pertinente; pois há já de início a formulação de uma personagem que destoa do senso comum.

A primeira obra a ser tratada é Os Mistérios da Estrada de Sintra, no subcapítulo "1.1 - O Fradique de 'Os mistérios': o coadjuvante excêntrico"'. Neste romance Fradique Mendes é um querido amigo de uma das protagonistas da obra, que o recebe para uma conversa trivial; já da apresentação dessa personagem (amigo íntimo de Baudelaire, por exemplo), de seu discurso e de suas atitudes percebe-se se tratar de um homem de vanguarda, pintado fortemente com tintas da excentricidade.

Fradique aqui já se comporta como um possível mote, que mereceria certamente mais linhas. Acreditamos que Eça e Ramalho tinham já uma perspectiva para o desenvolvimento dessa personagem. Uma personalidade ímpar, de olhar diferente e aguçado, às vezes ácido, seria certamente levada a um nível de construção narrativa que seria substrato aos outros grandes autores.

A consistência e as regras são definidas com o Fradique de A Correspondência de Fradique Mendes. Obra tratada no subcapítulo "1.2 - A personagem consistente: o heterônimo". Definitivamente o "homem do século" ganha vida neste momento, pois todo aquele potencial excêntrico é colocado em prática. Fradique é construído como heterônimo (com biografia bem definida), já que em toda a primeira parte (que segundo o crítico Fernando Venâncio, em entrevista anexa, poderia ser lido como um romance) é apresentado a público, como personalidade do cotidiano português.

Todavia é apresentado com honras e glórias, o grande autor de Lapidárias, obra, segundo o narrador, de extensa qualidade literária. É mostrado como observador ímpar da sociedade lisboeta, e para quem as fronteiras são meras demarcações políticas. Profundo conhecedor da África e do oriente, um viajante que, além de observar e criticar, passa a fazer parte do ambiente, passa a ser um personagem empírico (um flâneur) - um dos traços (regras) de que Agualusa mais se aproveita na sua efabulação - um potencial explorado com maestria, segundo o crítico Fernando Venâncio.

Este "próximo a efabular" traz um Fradique que coloca em prática tudo aquilo que é enunciado na obra de Eça. Uma personagem empírica que vive, à maneira lírica (conhece a grande 
paixão de sua vida - Ana Olímpia - uma negra senhora de escravos) e engajada (vive no Brasil a experiência de se "filiar" a uma sociedade abolicionista), promove a Fradique novas situações, o que o faz crescer como mito e como homem do mundo. Material todo este que será, em tom ensaístico, aproveitado por Venâncio.

Fradique volta a ser desenvolvido pelo autor de Esquemas pelo gênero romanesco, o que abre a possibilidade de construção mais complexa da personagem. Aqui ele ganha vida (por meio de descendentes, neto de Ana Olímpia, de Nação Crioula e neta de Lobiska, de O Único Filho de Fradique Mendes) pela voz de Martinho, um jornalista que tenta, por meio da pesquisa de documentos que falam sobre esse ilustre homem, (re)montar sua trajetória, criar sua fração e enredar parte da biografia de Fradique Mendes.

Venâncio faz uma retomada de alguns dos importantes efabuladores - principalmente Agualusa - a fim de colocar essa personagem no limiar entre a ficção e a história de Portugal, em um processo de enjambement narrativo tentando unir “os Fradiques” em uma única biografia, e o faz.

À frente três desses trabalhos que têm por objetivo demonstrar como o processo de efabulação se constitui a partir de um descompasso dessa personagem, em todos os momentos, frente sua conjuntura. Uma inadequação que faz com que seus autores possam, às suas maneiras, interagir com o meio com o objetivo de negá-lo ou colocá-lo em xeque.

Fradique Mendes então funcionaria como objeto de quebra de um status quo, tanto em relação a Portugal, a África ou até mesmo no contexto brasileiro. Um jogo que se estabelece entre os autores, a fim de se escreverem, se lerem, se citarem em favor de algo maior, a construção de um bem literário único e principalmente crítico.

Ler Fradique não é ler Eça ou Ramalho, é ler algo novo e principalmente algo único em um sentido estilístico. O que Fernando Pessoa fará magistralmente no modernismo português, com a criação de Álvaro de Campos, Ricardo Reis e Caeiro.

Essa força narrativa se dá pela constituição de uma função autor, Eça constrói antes de qualquer texto assinado por Fradique uma biografia deste homem. E o torna real principalmente quando cria um texto em primeira pessoa em que conta sobre seus encontros com o autor das Lapidárias.

Trata-se de primeiro apresentar a pessoa (o autor) para depois apresentar sua produção (as cartas), que é definitivamente composta em um estilo peculiar. Sobre a simulação da existência de Fradique, Paulo Motta disserta:

São, por sinal, várias as formas que o narrador do livro, que se assume como Eça, utiliza para simular a real existência de Fradique. Uma das mais frequentes é o uso do testemunho de seus amigos e contemporâneos. Por exemplo, após afirmar que o 
autor das Lapidárias "do outono de 1875 ao verão de 1876" travou contato, em Lisboa, com "alguns dos seus camaradas", o memorialista passará a se referir a opiniões desses amigos sobre Fradique, incluindo aqui - num procedimento que, como vários desse livro, poderíamos considerar como bastante camiliano - a transcrição de cartas de Oliveira Martins, Ramalho Ortigão e Guerra Junqueiro. Em outro segmento do livro - aqueles que são discutidas as características da suposta obra que teria sido escrita por Fradique, e que estaria nos papeis que o autor das Lapidárias, após a sua morte, legou a Madame Lobriska - serão expressas, entre outras, as opiniões de J. Teixeira de Azevedo, Oliveira Martins e Ramalho Ortigão. (OLIVEIRA. 2001. pág. 92/3)

O caso Fradique Mendes, a nosso ver, vai além de um heterônimo (um autor que cria uma biografia paralela para uma personagem), ou seja, aquele personagem que ganha status de autor real. Fradique vai, no decorrer do tempo, e ganhando cada vez mais forma de realidade, não só pelas mãos dos autores que me proponho a trabalhar, mas sim pelas mãos de todos os efabuladores, até mesmo por parte da imprensa portuguesa, que sempre publica alguma carta ao grande homem do século XIX, a fim de discutir principalmente política.

Há em cada efabulação novas informações sobre a vida desse autor e há em cada nova criação (fração) o aproveitamento de lacunas narrativas para que mais peripécias desse "herói".

Um dos autores efabuladores, Fernando Venâncio, autor de Esquemas de Fradique, em um de seus textos de crítica: Objetos achados - Ensaios literários, enumera os principais autores que efabularam sobre Fradique Mendes em ordem cronológica, e apresenta a sua trajetória nos diferentes textos.

João Chagas: 1909 - “a Fradique Filho, que, de Paris, pergunta quando acaba isso" Carta direcionada a João Chagas, que informa Fradique dos acontecimentos portugueses, e articula críticas sobre a sociedade portuguesa e apoia o fim da monarquia.

Antônio Sardinha; no artigo “In Memoriam de Eça de Queiroz”, publicado em 1922, cogita o destino e o conteúdo do espólio de Fradique Mendes. Diz que Eça afiançava esta em posse de Mme. Lobriska, a última amante do janota. Ela teria levado um cofre com toda a publicação de Eça para a Rússia (mote retomado por Venâncio na figura de Leonor). E soube que todo o espólio do excêntrico homem fora perdido em um incêndio no palácio de Palidorff, onde estavam guardados; isso acontecera durante a revolução de 1917. Sardinha descobre que Fradique e Lobriska tiveram um filho, que se torna cônsul e se encontra com Eça de Queiroz e com Pio XI, a quem piedosamente pediu para que orasse pela salvação de Portugal.

Frederico Perry Vidal: 1950. Escreve um livro chamado O Único Filho de Fradique Mendes: em que narra a trajetória do príncipe de Palidorff, filho do janota com Madame Lobiska (mote também trabalhado em Esquemas de Fradique na figura do Dr. Cristiano).

José Eduardo Agualusa: 1998. Coloca Fradique em novas situações, em África, "levando a mitificação fradiquiana a um nível incalculável. Sendo totalmente credível como história" 
(VENÂNCIO, 1999).

E, por fim, Fernando Venâncio, mesmo que o próprio autor não mencione seu livro Esquemas de Fradique, 1999, em que um jornalista, Martinho, faz uma pesquisa minuciosa sobre a vida de Fradique, descobrindo novos descendentes e até mesmo se encontrando com alguns deles.

Não levamos em consideração aqui os textos de imprensa e as publicações de A Morte de Fradique Mendes, de Joaquim Francisco Coelho, Autobiografia de Carlos Fradique Mendes, de vários autores e os Versos de Carlos Fradique Mendes, com prefácio de Pedro da Silveira. O que vemos aqui, contudo, é um heterônimo sendo criado no decorrer do tempo, e por várias mãos. E nesse processo há uma coerência bastante peculiar. Já que em toda essa produção parece que nada escapa daquele Fradique original queirosiano, engajado, crítico, irônico, mas em cada mão há também algo de singular. Todos eles carregam o mesmo caráter de inovação do primeiro Fradique, de Eça a Venâncio (dos que propomos trabalhar), ou ao futuro efabulador, que certamente virá, com um mesmo Fradique, um homem novo, além de seu tempo, e defensor de causas:

\begin{abstract}
"A criação da personagem Carlos Fradique Mendes conteve, desde o primeiro instante, um elemento de provocação, e, portanto um estímulo" "E é esta assumida artificialidade [representar o satanismo - inovação poética], sublinhada pelo abraçar de uma moda, o que veio permitir, e estimular, o à-vontade de quantos, e foram bastantes, se decidiram a recriar Fradique Mendes." Pode dizer-se que o convite à efabulação está no próprio seio da figura. Moral desta história: a grande criação de Eça de Queiroz continua, com espetacular perenidade, a canalizar as mais diversas preocupações. (VENÂNCIO. 2002. pp. 157; 166)
\end{abstract}

Portanto, um jogo de paráfrases, paródias e intertextualidade assinadas por um mesmo heterônimo, que carrega elementos que são respeitosamente coerentes nas efabulações: a excentricidade, a coragem, a ação, a visão e análise minuciosas dos fatos, o engajamento etc. Sempre quando há algo a dizer sobre Portugal, África ou até mesmo Brasil, Fradique é uma voz pertinente, principalmente quando há a necessidade de um tom irônico, como podemos perceber em todas as efabulações propostas:

A propósito de castelos: cartas de Portugal anunciaram-me que o quiosque por mim mandado erguer em Sintra, na minha quintarola, e que lhe destinava como "seu pensadoiro e retiro nas horas de sesta" - abateu. Três mil e oitocentos francos achatados em entulho. Tudo tende à ruína num país de ruínas. $\mathrm{O}$ arquiteto que $\mathrm{o}$ construiu é deputado, e escreve no Jornal da Tarde estudos melancólicos sobre as Finanças! (QUEIROZ. 1923. pág. 143- Carta escrita em Paris, à Madame de Jouarre)

Procurador-de-Cristo é o curioso nome com que no nordeste desse país são conhecidos os assassinos profissionais. Ao receberem uma proposta de trabalho, os pistoleiros vão com os mandantes à missa, e no momento solene em que o sacerdote ergue a hóstia, recebem o salário combinado e a bala com que hão-de executar o serviço. Através deste ritual os assassinos acreditam-se libertos da 
responsabilidade do crime, pois Cristo viu-os do altar, testemunhou o compromisso assumido e guardou o rosto do mandante. (AGUALUSA. 1998. pág. 104 - Carta escrita em junho de 1877, Rio de Janeiro, para o amigo Eça de Queiroz)

Passa-se então que o Rei encarregou o Fradique Mendes de determinadas missões de observação, bom, chamemos a coisa pelo nome, espionagem. (VENÂNCIO. 1999. pág. 156 - Martinho fala sobre possíveis trabalhos de espionagem contratados pelo rei.)

Bem ao contrário, eu sou o mais exemplar representante do típico português da alta burguesia: Tenho no banco as minhas inscrições a seis por cento ao ano, gosto de ouvir uma boa pilhéria ou um picante boato político digo diariamente mal do meu país e adoro o bacalhau de cebolada. A circunstância de me vestir de Poole não me subtrai - ao contrário do que os meus amigos julgam - à fatalidade hereditária de ser português! (MARCOS. 1996. pág.183)

Só lhe posso comunicar uma impressão d'homem, que passou e olhou. E a minha impressão é que os brasileiros, desde o imperador ao trabalhador, andam a desfazer e, portanto, a estragar o Brasil. (QUEIROZ. 1938. pág. 380 - Última Carta de Fradique Mendes, Paris, 1888.)

Ler Fradique Mendes é ler também a história portuguesa, levando em consideração, e principalmente, as relações dessa nação com suas colônias e ex-colônias. É muito cuidadoso o trato narrativo português principalmente quando há a elaboração de uma personagem criada para criticar a política e a cultura portuguesas frente sua condição periférica na Europa.

Tratar Fradique narrativamente é se enveredar em assuntos delicados para o português, como a própria questão da identidade nacional, e criticar essa identidade com um homem em que em sua essência não há o olhar português e, como visto acima, há somente uma "fatalidade hereditária de ser português" é de fato enveredar em terreno minado. É o que fazem corajosamente os efabuladores.

Fradique escreve suas cartas de Paris (quando em Eça), de Angola e Brasil (quando em Agualusa), portanto, um cidadão do mundo. A condição portuguesa de apatia, de não movimento, de vida em espera do mito (sebastianismo) não se aplica ao olhar aguçado de Fradique Mendes, o que o aproxima da biografia de seu principal criador:

Alguns veem a personagem como alter ego do seu criador, tamanhas são as afinidades [que] podem ser encontradas entre o pensamento de Eça e as reflexões elaboradas com o fino humor que caracteriza sua personagem. Outros percebem em Fradique uma identidade maior não com o escritor, ou melhor, não apenas com ele, mas com o ambiente burguês característico do final do século XIX europeu. (FONSECA. 2001. pág. 254)

Venâncio, em entrevista na cidade de Lisboa, em 11 de janeiro de 2011, e quando perguntado se há algo de legitimamente português na figura de Fradique, afirma: 
Creio que uma das graças de Fradique é que exatamente tem muito pouco da figura do português. É alguém que acumula durante a sua vida várias existências, sendo impossível que pudesse fisicamente fazer tudo o que ele fez. Nem viveu muito, morreu com cinquenta e poucos anos. E, no entanto, ele teria visitado praticamente tudo no mundo, menos a África austral e o Brasil, onde o romancista José Eduardo Agualusa o leva, no romance Nação Crioula. Nesse sentido, o Agualusa ainda junta a impossibilidade que o Eça descreve com outra impossibilidade. Fradique contactou com toda a gente importante que havia no mundo, leu tudo o que havia de importante pra ler, o que é muito, aprendeu uma porção de idiomas, e ainda tinha tempo para a sua existência de dândi, com as suas aventuras, com seus esportes. Nesse sentido, ele poderia no máximo ser um inglês com umas tintas francesas, tintas de italiano, mas português muito pouco. Eu não tenho a certeza do que vou dizer, mas podíamos suspeitar que o Eça fez dele alguém que exatamente não poderia ser português. E, no entanto, era português. Honra-nos muito. Fradique seria o melhor de nós. O melhor no sentido neutro, portanto, a melhor parte de nós, e também o melhor indivíduo português pensável. E talvez essa não só impossibilidade de ele existir como pessoa, mas também a sua não portugalidade, talvez tudo isso faça parte do jogo mental que o Fradique é. Sim, é um jogo mental do Eça. Há quem entre pela simbologia e diga que é uma espécie de compensação do Eça, que sempre teria tido um complexo de inferioridade, ao ser um filho ilegítimo. Não é necessário entrar por aí. A genial construção daquela figura já enche todas as medidas. (Entrevista publicada na Revista ContraPonto, Belo Horizonte, v. 1, n. 1. 〈http://periodicos.pucminas.br/index.php/contraponto > p. 1324, jul.2011. Visitado em 23 de agosto de 2011)

Contudo, vemos que há força narrativa suficiente nesse heterônimo para que possamos tratar da função autor, ou seja, o que esse autor representa para que tudo aquilo que ele produza possa ser dito como sua obra, e tenha caráter valorativo para uma população leitora. Foucault (2009) nos coloca uma questão bastante pertinente sobre a definição de obra, que nos faz pensar no caso Fradique: "O que é uma obra? Em que consiste essa curiosa unidade que designamos por obra? Que elementos a compõem? Uma obra não é o que escreveu aquele que se designa por autor?”. Se analisarmos

Ao olharmos Fradique Mendes como autor, percebemos um processo de bastante complexidade em relação à sua "obra". Sabemos que esse heterônimo é resultado da criação de Eça, mas esse heterônimo é um autor de extrema importância que extrapola a próprio trabalho de seu criador, chegando ao ponto de esse mesmo Fradique influenciar posteriormente os textos do próprio Eça. Questão levantada por Ana Nascimento, em seu estudo intitulado Fradiquismo e Modernidade no Último Eça, de 2003.

Será que tudo aquilo que Eça nos deixou, com base em Foucault - O que é um Autor? - até mesmo um recibo de lavanderia seria dito parte de sua obra? Certamente não. Mas e se Fradique Mendes nos tivesse deixado recibos de lavanderia? Qual seria o valor disso? Certamente esse simples recibo poderia ser mote, em quaisquer das mãos para preencher as lacunas narrativas dessa imensa biografia. Poderia de fato ser estopim para que um futuro efabulador encontre um erro, assim como Venâncio aponta em Agualusa, de cronologia nessa imensa rede de criação. E ao 
mesmo tempo em que esse recibo não fosse real, faria mesmo assim parte de uma biografia que beira o real, o histórico (assim todos os efabuladores trabalham - um Fradique real - mesmo que Venâncio se enverede mais nessa questão).

Qualquer elemento que adicionasse informação a esse autor Fradique Mendes seria bemvindo para explicar qualquer ponto da malha cronológica desse autor enigmático, dessa biografia sempre em construção.

Apercebemo-nos da crescente quantidade de questões que se põem a propósito da noção de obra. De tal forma que não basta afirmar: deixemos o escritor, deixemos o autor, e estudemos a obra em si mesma. A palavra "obra" e a unidade que ela designa são provavelmente tão problemáticas como a individualidade do autor (FOUCAULT. 2002. pág. 39)

O que falar desse processo quando há Fradique Mendes no centro dessa teia?

Como em camadas discursivas, Fradique Mendes, em sua autoria, cresce indefinidamente. No centro desse tecido está o Fradique de Eça e Ramalho, na camada superior está o Fradique de $A$ Correspondência, acima os efabuladores, e todos compostos coerentemente, formando uma esfera perfeita. Nesse jogo qualquer incoerência faria um furo nessa malha, que é transparente. E acima dessa última camada há ainda camadas virtuais em potencial. Camadas que não carregam autores, mas potencialmente existem e indefinidamente.

Podemos dizer, pois, que há um Fradique autor acima de todos os outros. Há um potencial de criação imenso, e todo esse potencial, o que nos é bastante peculiar, é autobiográfico, como se a vida desse grande autor só pudesse aumentar, por isso todo fato seria de eventual criação, todo objeto deixado, toda lacuna seria de potencial preenchimento, até mesmo com um recibo lavanderia. E quando essas lacunas acabarem haverá descendentes infinitos que sempre terão algo a dizer sobre Fradique, um novo olhar, uma nova perspectiva até mesmo de um mesmo fato (como ocorre em Vidal e Venâncio).

Há outro processo que pode ser apontado na constituição de Fradique que é um deslocamento da função autor-criador. Segundo Bakhtin há um autor-pessoa, que é aquele representado pelo autor em sua vida particular e ao autor-criador que corrobora com discurso de Foucault sobre a função autor, aquele que se coloca como produtor de um discurso e transforma a matéria real em ficção, exteriorizando nesse processo um caráter valorativo.

Para se apreender as bases dessa conceituação [uma substância peculiar que caracteriza o autor-criador fundamentalmente como uma posição axiológica], é importante assinalar que, para Bakhtin, a grande força que move o universo das práticas culturais são precisamente as posições socioavaliativas postas numa dinâmica de múltiplas inter-relações responsivas. Em outras palavras, todo ato cultural se move em uma atmosfera axiológica intensa de inter-determinações 
responsivas, isto é, em todo ato cultural assume-se uma posição valorativa frente a outras posições valorativas. (BAKHTIN. 1988. pág. 38)

No processo de criação de Fradique Mendes temos um heterônimo que parece responder aos anseios de seu autor, parece falar por ele, apresenta-se até mesmo como um alter ego, como afirma Fonseca (2001). Esse novo autor começa a ganhar voz, mas já não é a voz queirosiana, começa a ganhar autonomia de discurso, já que se apresenta como personagem histórico e interage com pessoas reais, como dito, amigos de Eça.

Há, portanto, um deslocamento do autor-criador, como se Eça tivesse a necessidade de criar um autor para que esse, desprendido das amarras sociais e com sagacidade e excentricidades suficientes para que o discurso produzido por esse autor-criador pudesse ser mais independente e se fizesse ouvir com uma voz amplificada.

Além disso, há no estilo de Fradique algo de mais inflamado já que é um dândi e vive em viagens pelo mundo, principalmente pelo oriente. Um homem livre que tem como única e principal ocupação a observação, um flâneur que extrapola as fronteiras das galerias de arte e dos boulevards. Seu discurso pode ser também livre e sem preocupações.

Há algo, também, no gênero escolhido por Eça para compor Fradique que corrobora com a afirmação de independência e potencialidade, principalmente no sentido de oferecer ao texto maior credibilidade. A confidencialidade do gênero epistolar faz com que o texto se torne quase um documento secreto que vem a público, arrebatador ou revelador. Ler uma carta de Fradique é como entrar no íntimo e descobrir as suas verdadeiras impressões sobre algo, pois há somente um destinatário, e geralmente amigos ou confidentes amorosas. Ler uma carta é ter informações que possivelmente não se teria pessoalmente (tempo de elaboração do discurso) ou que não se teria em público.

Tem-se discutido muito sobre as vantagens e desvantagens literárias da forma epistolar na ficção. As desvantagens são óbvias - a implausibilidade do incessante recurso da pena, a repetição e a prolixidade que o método impõe muitas vezes nos fazem aprovar a imprecação de Lovelace: "Que apodreçam o ganso e a pena do ganso!". A principal vantagem consiste no fato de as cartas serem a prova material mais direta da vida interior de seus autores. Ainda mais que as memórias são, para repetir a frase de Flaubert, "le réel écrit", e sua realidade é do tipo que revela as tendências subjetivas e privadas do autor com relação ao destinatário e às pessoas mencionadas, bem como seu próprio íntimo. Conforme o dr. Johnson escreveu a mrs. Thrale: "As cartas de um homem [...] são apenas o espelho de seu peito, tudo que se passa dentro dele revela-se indisfarçado em seu processo natural. Nada é invertido, nada é distorcido, vemos sistemas em seus elementos, descobrimos ações em seus motivos. (WATT. 2010. pág. 202)

Como levanta Watt, há vantagens e desvantagens o trabalho com o gênero epistolar, para Fradique acreditamos que as vantagens sobressaem, pois ainda segunda Watt, são "a prova material 
mais direta da vida de seus autores". Fradique coloca sua vida privada, ou melhor, sua mulher e Eça colocam a vida privada de Fradique à tona, o que dá sem dúvida mais credibilidade ao texto e a crítica fradiquiana.

Mesmo sendo resultado de efabulações recorrentes, e talvez por isso mesmo, Fradique Mendes se tornou um autor singular, que não admite a separação entre um autor-pessoa e um autorcriador. É resultado de camadas discursivas que, mesmo nelas havendo as intencionalidades de seus determinados autores, se torna maior do que essas intencionalidades e ainda maior do que cada autor que o compôs, pois os engloba em um jogo narrativo que singularmente e, definitivamente, ganha vida. Autoria. 


\section{I - AS EFABULAÇÕES QUEIROSIANAS}

Como dito na introdução, aqui pretendemos apontar algumas das características particulares dos textos determinados no corpus. Buscar o que, devidamente, entra também nas regras propostas, mas que merece a sua devida observação, um olhar minucioso.

E por mais que seja, aparentemente, um processo de visão em separado, a todo o momento nos é inevitável a comparação entre os textos. Levantaremos as categorias, no tocante às regras, e assim compararemos alguns dos trechos das obras, dentro daquilo que nos é pertinente, e que foi levantado no primeiro capítulo.

\section{1 - O FRADIQUE DE “OS MISTÉRIOS”: O COADJUVANTE EXCÊNTRICO}

Aqui trataremos do Fradique de O Mistério da Estrada de Sintra, de Eça de Queiroz e Ramalho Ortigão - publicado em folhetim no Diário de Notícias, de 24 de Julho a 27 de Setembro de 1870, recebendo a primeira versão em livro em 1884.

A análise da personagem Fradique Mendes é ao mesmo tempo difícil e delicada, pois há certamente o risco de se enveredar por caminhos equivocados, principalmente se pensarmos que os Fradiques característica e intencionalmente caminham para lados opostos, o que de fato é um erro. Como dito, há frações de um Fradique maior, que está até para além das efabulações.

Há mais elementos em comum entre “essas personagens” que características que os diferenciem, levando em consideração que são múltiplos; mas essa multiplicidade caminha em uma linha de construção bastante semelhante, tornando-se fios que se entrelaçam, por mais que entendamos que as condições de produção desses discursos sejam distintas.

O principal eixo entre essas personagens, o que leva esses discursos em caminhos paralelos num mesmo sentido, e levando em consideração grande parte de suas efabulações, desde a matriz queirosiana até textos jornalísticos portugueses atuais, é sem dúvida o seu caráter de questionamento e de excentricidade.

Se levarmos em consideração a primeira aparição da personagem, na novela Os Mistérios da Estrada de Sintra, perceberemos que há na sua configuração elementos que o tornam, de certa maneira, único, pois já é tratado como "nome conhecido", o que lhe confere importância social e cultural. É também comparado a Baudelaire (que também leva o nome de Carlos), pois:

(...) tinha como ele o olhar frio, felino, magnético, inquisitorial. Como Baudelaire, usava a cara toda rapada: e a sua maneira de vestir, de uma frescura e de uma graça singular, era como a do poeta seu amigo, quase uma obra de arte, ao mesmo tempo 
exótica e correta. (QUEIROZ. 2008. pág. 196)

Certamente características que o singularizam frente aos clichês sociais. Há nele também, nessa primeira descrição, um misto de características tão distintas que dão a esse homem um caráter de completude, multifacetado, pois tinha "o seu exterior o que quer que fosse da feição romântica que tem o Satã de Ary Scheffer, e ao mesmo tempo a fria exatidão de um gentleman" (QUEIROZ. 2008. pág. 196). As habilidades que o caracterizavam eram de extrema erudição e sensibilidade e também, para fechar o quadro de excentricidades, é mostrado como um exímio viajante e contador de histórias.

Isso confere a essa personagem propriedade de discurso, ou seja, know how, como se ela pudesse contar sobre culturas e fatos históricos com sabedoria, pois esteve em lugares e datas: “Tocava admiravelmente violoncelo, era um terrível jogador de anuas, tinha viajado no Oriente, estivera em Meca, e contava que fora corsário grego.” (QUEIROZ. 2008. pág. 196).

Este Fradique de Os Mistérios já se apresenta elaborado com caraterísticas que lhe dão poder e propriedade para contar histórias, o que potencializa ainda mais a capacidade narrativa desse contador de experiências. Podemos nos remeter, também, aqui, a Walter Benjamin, que trata exatamente sobre essa questão da força narrativa em seu texto "O narrador - Considerações sobre a obra de Nikolai Leskov" (BENJAMIM. 1996), quando disserta sobre a importância da experiência no narrar ou a experiência motivadora do narrar:

É a experiência de que a arte de narrar está em vias de extinção, São cada vez mais raras as pessoas que sabem narrar devidamente [...] 2 - A experiência que passa de pessoa a pessoa é a fonte a que recorreram todos os narradores. E, entre as narrativas escritas, as melhores são que as que menos se distinguem das histórias orais contadas pelos inúmeros narradores anônimos. Entre estes, existem dois grupos, que se interpenetram de múltiplas maneiras. A figura do narrador só se torna plenamente tangível, se temos presentes esses dois grupos. "Quem viaja tem muito que contar", diz o povo, e com isso imagina o narrador como alguém que vem de longe. Mas também escutamos com prazer o homem que ganhou honestamente sua vida sem sair do seu país e que conhece suas histórias e tradições. Se quisermos concretizar esses dois grupos através dos seus representantes arcaicos, podemos dizer que um é exemplificado pelo camponês sedentário, e o outro pelo marinheiro comerciante. (BENJAMIN, 1996, págs. 198, 199).

Sobre isso Adorno também fala: "O que se desintegrou foi a identidade da experiência, a vida articulada em si mesma contínua, que só a postura do narrador permite." (ADORNO. 2006, pág. 56)

Embora fale sobre o contador sedentário, Benjamin dá importância especial ao viajante, lugar em que se pode metaforicamente enquadrar Fradique, um marinheiro comerciante - que se 
encaixa plenamente no perfil tradicional do imaginário português. E mesmo depois de Fradique ter suas experiências contadas em cartas, diferente do que aponta Benjamin, essa personagem se aproxima desse narrador primitivo, coerente e socialmente creditado.

Ainda no tocante ao texto de Benjamin há algo nesse narrador primitivo, ou marinheiro comerciante, que faz dessa figura um conselheiro, já que há nele a experiência de ter visto o que os outros não viram.

Esse caráter conselheiro é trabalhado ou é subentendido em toda a obra queirosiana em que Fradique é figura central e, também, em todas as efabulações (diríamos que de maneira exagerada em José Eduardo Agualusa), já que essa personagem é levada ao patamar de testemunha da história.

Fradique é, sem dúvida, um homem de causas, como veremos mais especificamente adiante. Em Eça, Fradique é a representação e o exemplo para o homem português do século XIX e em Agualusa há um homem que intensifica um olhar crítico para África colonial, com uma perspectiva libertadora e extremamente humana.

Na obra de Venâncio, uma personagem que instiga a criação de ficção sobre a ficção, que é pivô de uma situação de paródia em que se discute realidade, ficção, criação, metafísica, a relação do homem com seu tempo e sua história. Elementos e discussões que são, de certo modo, impulsionados e potencializados por uma personagem que carrega em si o elemento da credibilidade, da excentricidade e da experiência, sustentada principalmente pela sabedoria e pelo potencial crítico.

Camadas discursivas que carregam experiências também acumuladas, que podem ser pensadas como "levante" entendido em seu significado original:

Ela [a narrativa] tem sempre em si, às vezes de forma latente, uma dimensão utilitária. Essa utilidade pode consistir seja num ensinamento moral, seja numa sugestão prática, seja num provérbio ou numa norma de vida - de qualquer maneira, o narrador é um homem que sabe dar conselhos. (BENJAMIN, 1996, pág. 200).

Desde o início Fradique é retratado com a tinta da ironia tipicamente queirosiana:

Em Paris tornou-se célebre; era o que se poderia chamar um filósofo de boulevard. Tinha sido l'ami de coeur de Rigolboche, e quando ela rompeu por se ter apaixonado por Capoul, Carlos Fradique deixou-lhe no álbum uns versos quase sublimes, de um desdém cruel, de um cômico lúgubre, uma espécie de Dies irae do dandismo... Prometia a Rigolboche que quando ela morresse ele velaria para que ainda além do túmulo ela vivesse no chique, sentindo Paris na sepultura. Algumas das estrofes que ele traduziu para mim, e que depois se publicaram, fizeram sensação e escola... (QUEIROZ. 2008. pág. 196/7) 
Eça (2003), na introdução, disserta sobre as características desta personagem no tocante a sua potencialidade e substância:

Nesta obra, escrita, como é de conhecido, em peculiar parceria com Ramalho Ortigão, os extravagantes traços satânicos do inicial poeta de "Serenata de Satã às estrelas" surgem já substancialmente adensados, através desse olhar "frio, felino, magnético e inquisitorial", herdado da alma gêmea baudelairiana. Tais traços surgem ainda metamorfoseados no renovado perfil aventureiro de "corsário grego", a que se associa o de "filósofo de boulevard" (PIEDADE. 2003. pág. 4)

Em outra vertente, Fradique é, geralmente, descrito como mulherengo, característica que carregará por toda sua história nas efabulações, já que em A Correspondência tem como confidente a Madame de Jouarre e envia cartas de cunho romântico à Clara, "minha adorada amiga". Em Agualusa, se envolve apaixonadamente por Ana Olímpia, em Vidal a relação com Madame Lobiska e em Venâncio, o jornalista Martinho, por meio de uma pesquisa que o leva a produzir de maneira confusa ficção e biografia, traz à tona as já conhecidas relações com Ana Olímpia e Madame Lobiska e cogita uma relação com Rattazzi.

Ainda na primeira aparição, em Os Mistérios, temos a indicação das aventuras amorosas de Fradique, mas o que nos chama a atenção em "uns versos quase sublimes, de um desdém cruel, de um cômico lúgubre, uma espécie de Dies irae do dandismo...” é a forma com que trata essa relação, que ao olhar de um romântico seria uma situação "quase-morte", principalmente por ter sido "trocado" por outro cavalheiro.

O trecho nos mostra também que havia nesse Fradique o reconhecimento literário, pois seus versos “fizeram sensação e escola...", o que depois é também levado a pino por um segundo Eça, quando na elaboração do que podemos chamar de introdução às publicações das cartas de Fradique: “Os temas [...] dessas cinco ou seis poesias, reunidas em folhetim sob o título de Lapidárias, tinham logo pra mim uma originalidade cativante e bem-vinda.” (QUEIROZ. 1946. pág. 5)

A ironia fradiquiana é vista ainda de maneira mais acentuada nos próprios versos que são referidos abaixo, em que o tema da morte é trabalhado, mas não de maneira romântica e, sim, beirando a comicidade; sem dúvida o que aproxima esse poeta de seu amigo Charles Baudelaire, a arte da sugestão (dançar e fazer festa em sua sepultura?) e também a negação do entorpecimento produzido pela arte romântica, concomitantemente à negação da subjetividade exagerada:

\author{
E eu qu'inda te amo, ó palida canalha, \\ Que sou gentil e bom, \\ Far-te-ei enterrar numa mortalha \\ Talhada à Benoiton! \\ Irei à noite com Marie Larife, \\ Vênus do macadam, \\ Fazer sentir ao pó de teu esquife
}




\author{
Os gostos do cancan... \\ E no tempo das courses, p'lo verão \\ - Assim eu to juro - \\ Irei dar parte a tua podridão \\ Se o Gladiador venceu... ${ }^{4}$
}

Há no texto um exagero a fim de gerar um desconforto, mas ao mesmo tempo em que há esse deslocamento, há a constituição de uma excentricidade. Verificamos um Fradique piadista e provocativo, fruto de uma sociedade cheia de ideias pré-definidas.

Levando em consideração que essa personagem é produzida na segunda metade do século XIX e, que Portugal nessa época era metrópole de várias colônias africanas, nada mais excêntrico e ao mesmo tempo "chique" do que fazer piada com uma "negra antropófaga":

Eram dez horas. Carlos Fradique, com uma voz impassível, quase lânguida, contava as situações monstruosas de uma paixão mística que tivera por uma negra antropófaga. A sua veia, naquele dia, era toda grotesca. - A pobre criatura - dizia ele - untava os cabelos com um óleo ascoroso. Eu seguia-a pelo cheiro. Um dia, exaltado de amor, aproximei-me dela, arregacei a manga e apresentei-lhe o braço nu. Queria fazer-lhe aquele mimo! Ela cheirou, deu uma dentada, levou um pedaço longo de carne, mastigou, lambeu os beiços e pediu mais. Eu tremia de amor, fascinado, feliz em sofrer por ela. Sufoquei a dor, e estendi-lhe outra vez o braço...

- Oh! Sr. Fradique! - gritaram todos, escandalizados com a invenção monstruosa.- Comeu mais - continuou ele gravemente - , gostou e pediu outra vez. Falava com um sorriso fino, quase beatifico. Nós íamos revoltar-nos contra a cruel excentricidade daquela história. (QUEIROZ. 2008. pág. 197)

O que nos chama atenção e nos é inevitável fazer, tendo em vista a cruel piada desta fração fradiquiana, é uma comparação com o texto de José Eduardo Agualusa, que localiza essa personagem em África, e que com o passar do tempo e em interação com pessoas do lugar, amadurece sua visão frente ao exótico, internalizando uma cultura e fazendo, de certa maneira, parte dela, deixando de lado até mesmo suas amarras metropolitanas:

Ignoro, é verdade, o preço exato do ouro na bolsa de Londres, desconheço o destino de Livingstone e nem sequer consigo acompanhar a intrigas da corte. Em contrapartida sei que os ratos assados continuam a vender-se muito bem nos mercados de Luanda, a quinze réis a dúzia, enfiados pela barriga em espetos de pau, e que tem havido distúrbios no Sumbe e no Congo. (AGUALUSA. 2000. pág. $15)$.

O que ainda nos é mais perceptível, tratando das qualidades de conquista de Carlos Fradique

\footnotetext{
${ }^{4}$ Foi respeitada a formatação da edição escolhida. (QUEIROZ. 2008. pág. 197)
} 
Mendes, é a descrição de uma mulher ideal que a personagem faz quando do encontro com Rytmel, em Os Mistérios:

— A irlandesa — dizia ele — tem, mais que nenhuma mulher, a graça... Sobretudo a que vive junto dos lagos! A melhor religião, a melhor moral, a melhor ciência para um espírito feminino - é um lago. Aquela água imóvel, azul, pálida, fria, pacífica, dá um extremo repouso à alma, uma necessidade de coisas justas, um hábito de recolhimento e de pensamento, um amor da modéstia e das coisas íntimas, o segredo de ser infinito sendo monótono, e a ciência de perdoar... Exijo, na mulher com quem casar, que tenha as unhas rosadas e polidas, e um ano de convivência com um lago! (QUEIROZ. 2008. pág. 199).

O tipo de mulher que agrada a fração de Os Mistérios não é, certamente, o que agrada a fração agualusiana. Acima há uma mulher extremante passiva, já que é apresentada como a metáfora de um lago: calmo, imóvel, azul, pálido, frio, pacífico, recolhido, margeado etc. José Eduardo Agualusa "apresenta" a Fradique uma mulher que mais poderia ser metaforizada como uma queda d'água, já que esta tem movimento, força e potencial realizador. Assim é Ana Olímpia: "Veja o caso de Dona Ana Olímpia. Nasceu nesta cidade, filha de uma escrava, e é hoje uma das mulheres mais ricas do país, senhora de muitos escravos, poderosa e respeitada." (AGUALUSA. 2000. pág. 24)

Contudo, pudemos observar que a primeira fração fradiquiana é composta de um grande potencial para se tornar uma das personagens mais excêntricas da literatura portuguesa, além de já, desde o início, se apresentar de maneira ativa e com extrema personalidade, o que abre precedente à criação de uma segunda fração, a quem Maria Nazareth Soares Fonseca define:

Fradique é, de algum modo, a representação do homem livre, salvo da tirania das ideias feitas, liberto do modelo de educação servil e livresca que embota o espírito e amortece a curiosidade. Defende o conhecimento adquirido no contato direto com outras culturas e exibe a insatisfação própria do 'espírito indisciplinado e criador'. A figura do europeu formado pelos livros, diante da realidade pulsante, abomina-o do mesmo modo que a do turista apressado que superficialmente vê os novos lugares, sem neles se deter [...]. Fradique é, sem dúvida, a representação do homem itinerante, do curioso que perscruta as diferentes culturas com o olhar característico do viajante interessado. Mas, ao mesmo tempo, não deixa de ter o traço do humanista: ama as grandes causas, embora se afaste da militância e de procurar 'pelas vielas miséria a resgatar' (FONSECA. 2001. pág. 255).

Trará assim um Fradique empírico, que sairá deste quarto (local fechado), onde conversa com uma das protagonistas do romance, e irá se enveredar pelo oriente com Eça, e para África e Brasil com Agualusa, e será rememorado e terá mais traços de sua personalidade explorados por Vidal e Venâncio.

Novamente em Os Mistérios há algumas referências ao poeta Charles Baudelaire. Eça, sem 
dúvida, conhecia um tipo de personagem trabalhado pelo poeta: o flâneur:

Segundo ele (Charles Baudelaire), a multidão seria a usina de força do flâneur; isso estaria evidente em alguns de seus poemas, como Les petites vieilles e A une passante, que traduzem a ideia do burburinho urbano e da passante que, após ser minuciosamente observada e estudada pelo autor, corre o risco de nunca mais ser vista por ele. É durante o dia que os aspectos mais característicos da modernidade tendem a revelar-se; é quando a multidão se refaz, se consolida e a máquina a vapor põe-se novamente a produzir em larga escala para abastecer a cidade faminta de significados. É um cenário perfeito para o aparecimento dessa figura que está em todos os lugares e ao mesmo tempo em nenhum lugar. Entre todos, porém sozinho. Esse ser aparentemente indecifrável, que é o flâneur, dividido entre o encantamento e o temor da cidade. (Revista Eclética - PUC-Rio, julho/dezembro de 2003, pág. 7 Reportagem de Fernanda Passos, Mariana Gouvêa, Raphael Tosti e Rodrigo Polito).

Sem dúvida há algo da flanerie em Carlos Fradique Mendes: o olhar aguçado sobre o seu cotidiano, a busca de certo lirismo e expressividade naquilo que para a maioria das pessoas não passa de normalidade. Sem dúvida trazer Fradique à tona, posteriormente, como poeta (autor de Lapidárias) é dizer que este tem uma percepção poética sobre sua conjuntura. Mas, por mais que a flanerie esteja nesta personagem queirosiana, Eça extrapola seus limites.

E não só Eça faz isso: em toda a corrente das efabulações, Fradique Mendes vai além da flanerie e se torna, gradualmente, maior que uma personagem que deambula em seu cotidiano, pelas ruas, pelos boulevards, pelos cafés; passa a saltar fronteiras. Não somente fronteiras de Estados (até mesmo continentes em José Eduardo Agualusa), mas sim, e, também, extrapolando fronteiras de comportamento, até se tornar herói (e espião) a serviço da coroa em Fernando Venâncio (3.1).

Walter Benjamin, em "Charles Baudelaire - um lírico no auge do capitalismo", traz uma extensa explicação da flanerie quando disserta sobre um gênero literário, principalmente da década de 1840, que foi logo esquecido e que trazia a figura do flâneur:

A reação é, portanto, a condição que "explica a colossal passagem em revista da vida burguesa que se estabeleceu na França... Tudo passava em desfile... dias de festa e dias de luto, trabalho e lazer, costumes matrimoniais e hábitos celibatários, família, casa, filhos, escola, sociedade, teatro, tipos, profissões". A calma dessas descrições combina com o jeito do flâneur, a fazer botânica no asfalto. [...] A flanerie dificilmente poderia ter-se desenvolvido em toda plenitude sem as galerias. "As galerias, uma nova descoberta do luxo industrial - diz um guia ilustrado de Paris de 1852 - são caminhos cobertos de vidro e revestidos de mármore, através de blocos de casas, cujos proprietários se uniram para tais especulações. De ambos os lados dessas vias se estendem os mais elegantes estabelecimentos comerciais, de modo que uma de tais passagens é como uma cidade, um mundo em miniatura.". Nesse mundo o flâneur está em casa; é graças a ele "essa paragem predileta dos passeadores e dos fumantes, esse picadeiro de todas as pequenas ocupações imagináveis encontra seu cronista e seu filósofo". E para si mesmo obtém o 
remédio infalível contra o tédio que facilmente prospera sob o olhar de basilisco de um regime reacionário saturado. "Quem é capaz - diz uma frase de Guys, transmitida por Baudelaire - de se entediar em meio à multidão humana é um imbecil. Um imbecil, repito, um desprezível.” As galerias são um meio termo entre a rua e o interior da casa. Se quisermos mencionar uma artimanha própria das fisiologias, falaremos de uma dos folhetins, já comprovada: a de transformar os bulevares em interiores. A rua se torna moradia para o flâneur que, entre as fachadas sente-se em casa tanto quanto o burguês entre suas quatro paredes. Para ele os letreiros esmaltados e brilhantes das firmas são um adorno de parede tão bom ou melhor que a pintura a óleo no salão do burguês; muros são a escrivaninha onde apoia o bloco de apontamentos; bancas de jornal são suas bibliotecas, e os terraços dos cafés, as sacadas de onde, após o trabalho, observa o ambiente. Que a vida em toda a sua diversidade, em toda a sua inesgotável riqueza de variações, só se desenvolva entre os paralelepípedos cinzentos e ante o cinzento pano de fundo do despotismo: eis o pensamento político secreto da escritura de que faziam parte as fisiologias. (BENJAMIN, 2000, págs. 34 e 35)

Fradique Mendes carrega de fato algumas das características de um flâneur, como o olhar perspicaz, aguçado e crítico frente um objeto. Há nas ruas de Lisboa o substrato para essa inebriação do flâneur? Eça mostrará que não e ainda potencializará essa personagem para que Agualusa possa mostrar que, definitivamente, Fradique não se contenta somente com galerias de arte e cafés.

É um homem do mundo, e por ele viajará, atravessará continentes. Tornar-se-á consistente e real em A Correspondência, atravessará o continente africano em busca de novas experiências, onde encontrará, segundo Agualusa, a mulher de sua vida e, de maneira lírica e ao mesmo tempo engajada, enfrentará novos desafios.

E ainda pelas mãos desse autor angolano chegará ao Brasil em um navio negreiro e conhecerá a lendária figura de José do Patrocínio. Para que, em outra etapa pelas mãos de Venâncio, possa ter sua trajetória (re)montada em um romance com características de ensaio, pós-moderno, que tratará a figura de Fradique como, incontestavelmente, um cidadão do mundo e herói português.

\section{2 - A PERSONAGEM CONSISTENTE: O HETERÔNIMO}

Aqui teremos como objeto de estudo a obra A Correspondência de Fradique Mendes Memórias e Notas (Publicada em 1900). É nesta obra que delimitadamente se constitui a personagem Fradique Mendes como heterônimo, ideia defendida por Paulo Motta de Oliveira - e já comentada por Joel Serrão: "Em boa e chã verdade, pouquíssimo se sabe acerca do breve período durante o qual foi criado o heterônimo coletivo Carlos Fradique Mendes, a não ser que esse fato terá ocorrido entre os fins de 1868 ou começos de 1869 e Maio ou Junho de 1869. (SERRÃO. 1985. pág. 197), e como alter ego de seu criador, ideia trabalhada também por Ana Nascimento Piedade. 
Nas três obras contemporâneas propostas há um eixo de construção bastante peculiar e que é essencial neste Fradique matriz, principalmente em sua criação, motivadora, como afirma Piedade, de um "disfarce estilístico":

Fradique resulta, pois, de um <<disfarce estilístico〉> assumido em conjunto, surgindo nessa altura, associado à tentativa de pôr cobro ao que os três jovens escritores designavam como <<apatia chinesa dos lisboetas〉>, ou seja, esse permanecer imobilizado <<durante anos, na contemplação e no cinzelar de meia ideia, velha, indecisa, em segunda mão e mau uso>>. (PIEDADE. 2003. pág. 15)

E ainda Fernando Venâncio disserta sobre essa condição inicial da criação, que é levada e aprimorada pelas efabulações propostas:

A criação da personagem Carlos Fradique Mendes conteve, desde o primeiro instante, um elemento de provocação e, portanto um estímulo" "E é esta assumida artificialidade [representar o satanismo - inovação poética], sublinhada pelo abraçar de uma moda, o que veio permitir, e estimular, o à-vontade de quantos, e foram bastantes, se decidiram a recriar Fradique Mendes. Pode dizer-se que o convite à efabulação está no próprio seio da figura. (VENÂNCIO. 2002. pág. 157)

Sem dúvida há na intencionalidade de criar Fradique Mendes a oposição à visão tradicional e "velha" de maus hábitos. Há uma intencionalidade de modernização do pensamento. Piedade então nos dá a valiosa informação de que Fradique surge de um movimento de revitalização e modernidade.

Eça, e também os outros autores, cria uma personalidade, lhe dá vida, como já na criação individual queirosiana (Memórias e Notas), para que ela tenha assim propriedade de discurso. Criase um falar "falso" para uma ocasião pertinente de crítica. Como dito, os romances propostos “jogam” muito bem com essa condição da criação de outrem para que este fale por uma condição ou propósito.

Todo leitor perspicaz admira alguns escritores principalmente pelo estilo que estes aplicam ao seu modo de produzir literatura. Cada escritor se constitui como tal por empreender um estilo próprio e se destaca por isso. E os textos aqui propostos carregam um fio lúdico sobre essa questão estilística. Assim como Eça e seus companheiros propuseram a criação de um estilo próprio de Fradique Mendes - já que o estilo de Fradique não é o mesmo que o estilo de Eça ou mesmo que de Ramalho Ortigão, mas sim um terceiro estilo muito bem trabalhado e próprio: Agualusa recria (foge do seu estilo próprio de escritor) e remonta ao estilo fradiquiano; Venâncio retoma todas as outras recriações e com base nelas estrutura um narrador que recria, agora com estilo próprio, vezes ficção, vezes documento, vezes os dois ao mesmo tempo, um Fradique (in memorian) e retoma toda 
a discussão sobre autenticidade, metafísica e realidade, temporalidade narrativa, discurso ideológico, que se colocam de maneira latente.

E essas construções só são possíveis porque há em todo esse processo uma sobreposição de discursos que tem como base um estilo inicialmente composto e, como dito, um jogo de coerências bem marcado.

Em Agualusa se torna muito clara essa condição no sentido de que se cria, ou melhor, se recria (disfarce do disfarce estilístico) essa personagem para que ela dê condição de desmitificar ela mesma, ou seja, colocar "em xeque" o que essa personagem acreditava ser verdade no tocante à visão e percepção do que seria a condição africana no final do século XIX.

$\mathrm{O}$ autor angolano leva essa personagem, essa primeira pessoa autora de cartas, para um contexto empírico, fazendo com que ela possa vivenciar um mundo "desconhecido" e por ser desconhecido, mitificado. Podemos falar que esse jogo de disfarces faz com que a mimesis (o ato de criação - recriação, representação) possa quebrar um estereótipo (a visão preconceituosa europeia sobre África - especificamente Angola).

Poderia se pensar que se um Agualusa decide escrever crônicas de viagens, como de praxe, descrevendo lugares e costumes, esse narrador, embora tivesse propriedade para escrever sobre o que observa, não tem a força que traz certo Fradique, um narrador muito bem marcado temporal e ideologicamente. Para a narrativa é de fato de extrema força apelativa, pois Fradique representa um ideal (por isso na ficção) do que Eça (e inicialmente seus companheiros) acreditava ser o homem perfeito.

Tanto que serve como artifício para que Agualusa o coloque em um contexto que desmitificaria uma ideia preconcebida sobre Angola. E essa narrativa é de fato tão forte e só acontece porque o autor disfarça o estilo queirosiano, ou melhor, fradiquiano.

E não tenhamos aqui uma simples cópia, mas sim uma tradução (aquilo que reflete, que expressa de modo indireto; repercussão, imagem, reflexo - Dicionário Houaiss) que remonta ideologicamente essa personagem, e com isso todo o processo narrativo:

"Era, dizia V., 'uma forma de homenagear o português mais interessante do século XIX, e era também um ato de patriotismo', pois nos tempos incertos e amargos que vão, Portugueses destes não podem ficar para sempre esquecidos, longe, sob a mudez de um mármore.” (FONSECA. 2001. pág. 253 - Citação de uma carta de Ana Olímpia a Eça de Queiroz)

Sobre isso, Maria Nazareth Soares Fonseca nos mostra, por meio da citação de uma carta que Ana Olímpia escreve para o escritor Eça de Queiroz, reproduzida acima, e discute com ele a publicação das cartas inéditas, que há, no ato de recriação, a formulação de um caráter de propriedade, ou seja, e como exposto, não se trata de simplesmente um narrador desconhecido 
falando de suas experiências em um lugar igualmente desconhecido. Trata-se de um "português que não pode ficar esquecido" em um lugar que se torna conhecido, e não só isso, um lugar que se torna conhecido por uma ótica especialíssima, tornando-se assim, também especial, e documental. O que aproxima o texto de Agualusa a um documento histórico, como diz ainda Fonseca:

[Fradique] é também testemunho de outros modos de registrar o mundo e é com a intencionalidade evidente de brincar com a história e com a literatura de feição nacionalista que o romance [Nação Crioula] coloca-se no limite entre invenção e registro. (FONSECA. 2001. pág. 254)

Em A Correspondência de Fradique Mendes, verifica-se já em seu primeiro parágrafo momento em que o autor narrador, que se diz Eça de Queiroz, se apresenta - que se começa a acontecer um contato mais íntimo entre o narrador e o poeta Fradique Mendes, e já nos é retratado um viajante, pois este contato "começou em 1880, em Paris, pela Páscoa, - justamente na semana em que ele regressara de sua viagem à África Austral” (QUEIROZ. 1923. pág. 5).

Parece que o autor já quer deixar claro desde o início uma das principais características dessa personagem: um ser viajante. O que, certamente, será explorado nas frações propostas, principalmente naquela que conta suas peripécias amorosas com Ana Olímpia.

Além de nos apresentar um viajante, nos mostra que em 1867 viu em letras grandes o nome de Carlos Fradique Mendes e seus poemas em um jornal chamado Revolução de Setembro, o que nos leva a perceber que o autor daqueles poemas era possivelmente partidário de ideias revolucionárias, já que este jornal foi o mais importante e influente para o liberalismo português, e uma exceção na imprensa portuguesa, em 61 anos de edições, já que a vida dos jornais era, regra geral, muito fugaz:

A fama de ARS leva José Estêvão a convidá-lo para colaborar n'A Revolução de Setembro. O jornal, então com cerca de 50 assinantes, começa, com os artigos de ARS, mas, sobretudo, com os seus editoriais, a ter uma projecção até aí desconhecida, e rapidamente chega aos 1000 assinantes, o que para a época era muito significativo. E também rapidamente se transforma no jornal mais importante e influente do Liberalismo. Um sucesso que se traduziu também nos 61 anos de edição regular d'A Revolução de Setembro (1840-1901), o que não deixa de constituir um caso único na história da imprensa periódica portuguesa, pois a vida dos jornais era, regra geral, muito fugaz. N'A Revolução de Setembro é possível identificar três correntes políticas: a ordeira, liderada por Almeida Garrett; a moderada, isto é, ligada à esquerda moderada do Setembrismo, liderada por José Estêvão; e a radical, liderada pelo partido popular, os clubes e a imprensa radical. Com a radicalização da vida política portuguesa, a partir de 1846/47, o jornal também se radicaliza, linha que manterá até ao golpe da Regeneração, em 1851 . O tema principal nas páginas d'A Revolução de Setembro é a luta contra a ditadura administrativa e parlamentar de Costa Cabral. (Rodrigues Sampaio e a Revolução de Setembro, Conferência apresentada por José Manuel Tengarrinha (UL/FL) Recensão, por Álvaro Costa de Matos. 2006) 
Um Fradique viajante, colaborador do periódico A revolução de Setembro, também no início o narrador nos caracteriza um Victor Hugo da poesia, no sentido de se produzir um texto poético revolucionário:

Ora Fradique Mendes pertencia evidentemente aos poetas novos que, seguindo o Mestre sem-igual da Légende des Siècle, iam, numa universal simpatia, buscar motivos emocionais fora das limitadas palpitações do coração - à História, à Lenda, aos Costumes, às Religiões, a tudo que através das idades, diversamente e unamente, revela e define o homem" (QUEIROZ. 1923. pág. 6).

De fato Fradique Mendes se posiciona através do narrador como homem de aventuras e revolucionário das letras. Assim como Victor Hugo, que no extenso prefácio de Cormwell rompe com os formalismos do classicismo, Fradique Mendes subverte o lirismo monótono e confidencial de martírios de amor, trazendo, segundo o narrador "um outro filão poético que me seduzia - o da modernidade".

Um dos poemas assinados por Fradique Mendes, que certamente se encaixa na proposta de um poeta que traz a "notação fina e sóbria das graças e dos horrores da vida, da vida ambiente e costumada, tal como a podemos testemunhar ou pressentir nas ruas que todos trilhamos" (Ibidem, pág. 25) segue:

\begin{abstract}
As Flores do Asfalto
As flores que nossa alma descuidada Colhe na mocidade com a mão casta, São belas, sim: basta aspirá-las, basta Uma vez, fica a gente enfeitiçada.
\end{abstract}

Nascem num prado ou riba sossegada, Sob um céu puro e luz serena e vasta: Têm fragrância subtil, mas nunca exausta, Falam d'Amor e Bem à alma enlevada...

Mas as flores nascidas sobre $\mathrm{o}$ asfalto Dessas ruas, no pó e entre o bulício, Sem ar, sem luz, sem um sorrir do alto,

Que têm elas, que assim nos endoudecem?

Têm o que mais as almas apetecem...

Têm o aroma irritante e acre do Vício!

Paris - 1867 (MENDES. 1973. pág. 37)

\footnotetext{
${ }^{5}$ As Flores do Asfalto. Com o título mudado para "Versos Escritos num Exemplar das Flores do Mal", figura na mesma obra de Antero. (ed. Cit.; págs. 211-212).
} 
Já no título o autor (Carlos Fradique Mendes) nos apresenta uma antítese que é montada com elementos que compõem sua modernidade, já que estamos falando de um poeta bastante contemporâneo. O asfalto, metáfora da modernidade e da impessoalidade. A falta de lirismo se contrapõe frente à flor, que no decorrer da poesia se transfigura em objeto de vício (personificado). Temática que será usada principalmente em textos modernos e pós-modernos, portugueses e brasileiros, trabalhada em demasia, esta antítese entre o asfalto e a flor, o moderno e o lírico, o impessoal e o íntimo.

De fato o narrador, que se diz Eça de Queiroz, fica inebriado com tais textos, já que se identifica com as observações e com a perspicácia poética deste "homem do século". As temáticas realistas eram o que chamava a atenção desse narrador, pois eram "nesses poemetos de Lapidarias [onde] se desenrolavam, com efeito, temas magnificamente novos” (QUEIROZ. 1946. pág 7)

Comparar ou buscar uma relação de proximidade entre Fradique e Baudelaire, ou Leconte de Lisle (que curiosamente também traz o nome de "Carlos" - Charles Marie René Leconte de Lisle) ou Victor Hugo é de fato fazer com que Fradique transite entre os "deuses das letras". Grandes poetas que habitam um Olimpo poético inalcançável.

[...] uma forma soberba de plasticidade e de vida, que ao mesmo tempo me lembrava do verso marmóreo de Leconte de Lisle com um sangue mais quente nas veias de mármore, e a nervosidade intensa de Baudelaire vibrando com mais norma e cadência. [...] toda uma pleiade d'estrelas novas onde sobressaiam, pela sua refulgência superior e especial, esses dois sóes - Baudelaire e Leconte de Lisle. Victor Hugo [...] não era para nós um astro, mas um Deus" (QUEIROZ. 1946. pág.8)

Parece-nos que nessa parte inicial do livro há uma tentativa de construção de uma personalidade que se aproxima das grandes personalidades do mundo das artes. Os "Charles" são parecidos e o "Charles" português comporia a união ou a junção em pessoa do que há em melhor nos noutros. "E esse folhetim amarrotado da Revolução de Setembro tomava assim a importância de uma revelação d'arte, uma aurora de poesia” (QUEIROZ. 1946. pág. 12).

O narrador coloca toda sua admiração (também a dos camaradas) pelos principais poetas novos de sua geração - Baudelaire, Victor Hugo, Leconte de Lisle, Coppée, Dierx, Malarmé, Spencer, Taine etc. (outros que julga menores), compara Fradique em forma e conteúdo a esses poetas; mas Fradique parece se destacar frente todos esses pelo simples motivo de saber fazer com maestria tudo aquilo que os outros fizeram, mas como "tijolo" de sua construção Fradique tem aquilo que o narrador considera precioso, a língua portuguesa: 
Lapidárias de Fradique Mendes, onde julguei ver reunidas a fundidas as qualidades discordantes de majestade e nervosidade que constituíam, ou me pareciam constituir, a grandeza dos meus dois ídolos - o autor de Flores do Mal, e o autor dos Poemas Bárbaros. A isto acrescia, para me fascinar, que este poeta era português, cinzelava preciosamente a língua que até aí tivera como joias aclamadas o Noivado do Sepulcro e o Ave Cesar! Habitava em Lisboa, pertencia aos Novos, possuía decerto na alma, talvez no viver, tanta originalidade poética como nos seus poemas! [...] Graças te sejam dadas, meu Fradique bendito, que na minha velha língua hé mirado algo nuevo!” (QUEIROZ. 1946. pág. 12)

Fradique Mendes, reunidas todas as bem feitorias e qualidades deste ser, é conclamado como representante dos Novos Literatos do final do século XIX: “J. Teixeira d' Azevedo achou também 'sublime - mas brejeiro'. E concordou que convinha desentulhar Fradique Mendes da obscuridade, e erguê-lo no alto do escudo como o radiante mestre dos novos" (QUEIROZ. 1946. pág. 13).

Toda a geração de 70 passa a ter como grande mestre um ser ficcional que carrega, como o autor de Esquemas de Fradique diz em entrevista, "tudo aquilo que seria plausível para um português. Aquilo que todo o português queria e podia ser”. Há em Fradique, a partir dessa constituição de sua biografia, um homem "real" a ser seguido, uma vida para ser admirada. Uma obra a ser seguida (temos obra aqui a junção, segundo Bakhtin, de um autor-pessoa e de um autorcriador).

Fradique teve, como diz o narrador, uma educação "embrulhada", morou com parentes, fora criado ora por tios, ora por avó, mas há algo na educação de Fradique que nos chama a atenção: sempre tivera contato com literatura dos grandes cânones, com filósofos e documentos importantes para uma formação humana de extrema complexidade.

Fora também homem boêmio: “Carlos tocou guitarra pelo Penedo da Saudade, encharcou-se carrascão na lasca das Camelas [...] amou desesperadamente a filha dum ferrador de Lorvão. [Foi] reprovado em Geometria quando o avô morreu. [...] Carlos foi para Paris estudar direito nas cervejarias que cercam a Sorbonne" (QUEIROZ. 1946. pág. 17).

A construção de um homem que pode ser um exemplo do que se deve fazer - do que um português de fato pode ser ou se tornar - é aparentemente clara no texto biográfico criado pelo narrador, mas também há nessa personagem outro viés, o que o torna mais humano, pois há também defeitos e vícios.

Tal humanidade é potencializadora, e os efabuladores posteriores, principalmente Vidal, Agualusa e Fernando Venâncio, exteriorizam toda humanidade pungente de Fradique Mendes: em seus casos amorosos, melancolias e principalmente a sensibilidade de um homem de causas (visto exatamente em Agualusa). A sensibilidade em sua observação, o olhar e o poeta que habitam em Fradique Mendes são certamente resultado desses fatores trabalhados em sua biografia (alguns já 
trazidos em O Mistério da Estrada de Sintra), sua exímia educação, seu contato com os mais diversos tipos de pessoas, seu contato com as artes e com as mazelas sociais, mas acreditamos que principalmente essa sensibilidade poética tenha certamente sido resultado das viagens feitas por Carlos.

Como trabalhado no capítulo que trata de Os Mistérios, viagens sempre foram, se não o hobby, a necessidade de Fradique. Desde o início fora caracterizado como viajante, desde principalmente sua origem (corsários). Na definitiva biografia de Fradique não poderia deixar de haver explicações e destinos para as viagens que o formaram como pessoa: "Com tantas profundidade e miudeza conhecia o Oriente este patrício admirável!” (QUEIROZ. 1946. pág. 49).

O que corrobora a personagem posterior de Agualusa, autor que se aproveita dessa principal característica para de fato narrar os feitos de Fradique na África. A Correspondência de Fradique Mendes traz:

Com um ímpeto de ave solta, viajara logo por todo o mundo, a todos os sopros do
vento, desde Chicago até Jerusalém, desde a Islândia até o Saara. Nestas jornadas,
sempre empreendidas por uma solicitação da inteligência ou por ânsia de emoções,
achara-se envolvido por feitos históricos e tratara altas personalidades do século.
Vestido com a camisa escarlate, acompanhara Garibaldi na conquista das Duas-
Silícicas. Incorporado no Estado-Maior do velho Napier, que lhe chamava the
Portuguese Lion (o Leão Português), fizera toda a campanha da Abyssinia. Recebia
cartas de Mazzini. Havia apenas meses que visitara Hugo no seu rochedo de
Guernesey... (QUEIROZ. 1946. pág. 18)

Para Fradique Mendes não bastava viajar, precisava estar em lugares e momentos históricos com pessoas ilustres. Não só as viagens, mas o poder de conquistar quem quer que passasse pela sua vida foi também levado como principal característica pelos próximos efabuladores. $\mathrm{O}$ amor de Carlos por Ana Olímpia e sua influência para o fim do tráfico de negros para a metrópole e colônia, suas artimanhas políticas, grande convencedor, novos amores em Perry Vidal e a fixação que cria na mente de Martinho, quando este começa a vasculhar aquilo que Fradique deixou conhecer em sua cronologia (infinita) são resultado desse potencial biográfico gerado por Eça.

Fradique gera fixações em narradores e mulheres: "a sua derradeira residência em Jerusalém, durante dezoito meses, foi motivada (segundo me afirmou o consul Raccolini) por poéticos amores com uma das mais esplêndidas mulheres da Síria” (Ibidem, pág. 89), passantes, reis, imperadores, literatos, todos se rendem àquilo que Carlos pode oferecer, ou melhor, um homem que pode colher tudo aquilo que a civilização, seja ela qual for (principalmente não só a ocidental), pode proporcionar: "Fradique assumiu pra mim a estatura d'um desses seres que, pela sedução ou pelo gênio [...] dominam uma civilização, e dela colhem deliciosamente tudo o que ela pode dar em gostos e em triunfo.” (QUEIROZ. 1946. pág.19) 
Por mais que esta primeira parte de A Correspondência de Fradique Mendes possa ser entendida como a biografia de Carlos, há nela momentos de reflexão do próprio narrador, principalmente quando em sua segunda parte, onde esse Eça, após descobrir sobre os grandes feitos de Fradique, por meio do amigo em comum, Marcos Vidigal, se comporta de maneira angustiada na noite em que vai conhecê-lo.

Essa angústia coloca o narrador em uma posição passiva e amedrontada frente àquele que julgava o "homem do século". Ensaia frases já construídas: "A forma de v. ex. é um mármore divino com estremecimentos humanos!” (pág. 21).

A todo o momento Fradique é construído para ser grande. Como aquele herói de quem se sabe os grandes feitos. Quem todos conhecem e admiram. Chega este Mendes a habitar os sonhos do narrador, quando um dia antes do grande encontro sonha que passeia com Anna de Léon pela Via Sagrada, onde conversam sobre os versos das Lapidárias.

Por mais que seja uma biografia, é também uma narrativa em que há a figura de um narrador que vez ou outra reflete sobre si. Assim também, a nosso ver, acontece na efabulação de Fernando Venâncio, quando, em vários momentos da narrativa, Martinho se coloca em primeiro plano e também muitas vezes reflete se deve produzir literatura (ficção) ou "realmente" uma biografia. Narradores que se inebriam frente essa personagem complexa e enigmática.

Na obra de Eça, o exótico é sempre presente. Quando da construção da biografia de Carlos, no momento em que o narrador conhece Fradique, este está com problemas na alfândega por conta de uma múmia que importara de Paris (Pentaour - escriba ritual do templo de Amnon em Thebas, e cronista de Ramèzes II - Seria presente para Lady Ross, amiga de Athenas). Fato que deixa esse Eça e Marcos Vidigal intrigados. Quem parece trazer o exótico é a figura de Fradique Mendes. Em outro exemplo:

Fradique Mendes voltara de dentro, vestido com uma cabaia chinesa! Cabaia de mandarim, de seda verde, bordada a flores de amendoeira - que me maravilhou e que me amedrontou. [...] ordenou a 'soda e limão' a um criado surpreendente, muito louro, muito grave, com uma pérola espetada na gravata, largas calças de xadrez verde e preto e peito florido por três cravos amarelos. (QUEIROZ. 1946. pág. 29)

Em contra posição, em um dos futuros efabuladores, Eduardo Agualusa, há a apresentação do exótico em uma direção contrária. Fradique toma contato com elementos naturais e sociais que não eram de seu desconhecimento, o que dá a ele um caráter menos extravagante e propicia em Nação Crioula um homem que desce do seu patamar "inalcançável no olimpo poético" e passa a ser homem de experiências. Reflete sobre sua nova condição humana e acaba por colocar em xeque seu posicionamento anterior de superioridade. 
O centro da civilização, Paris? Sim, claro! Mas o que é a civilização? Entre o cavalheiro melancólico que frequenta os salões de Madame de Jouarre, minha gentil madrinha, e o remoto canibal do Alto Amazonas, não existe séria divergência moral, apenas gastronômica. (AGUALUSA. 2000. pág. 117)

Em outro viés, parece-nos que Fradique é usado por Eça para, mesmo que em um movimento de contradição frente o narrador da obra, levantar sutilmente um manifesto da prosa realista. Esta personagem levanta a importância se uma prosa precisa, lúcida e sóbria, o que seria a "genuína expressão da clara inteligência" e somente os "mais finos conhecedores" da literatura francesa saberiam reconhecer a importância da prosa realista, frente à "tumultuosa" poesia de Hugo e Baudelaire. Aqui se faz necessária uma longa citação:

Então, Fradique, sorrindo paternalmente, afiançou que bem cedo eu perderia essa ilusão! Baudelaire (que ele conhecera) não era verdadeiramente um poeta. Poesia subentendia emoção: e Baudelaire, todo intelectual, não passava de um psicólogo, de um analista - um dissecador sutil de estados mórbidos. As Flores do Mal continhem apenas resumos críticos de torturas morais que Baudelaire muito finamente compreendera, mas nunca pessoalmente sentira. A sua obra era como a de um patologista, cujo coração bate normal e serenamente, enquanto descreve, à banca, numa folha de papel, pela erudição e observação acumuladas, as pertubações temerosas de uma lesão cardíaca. Tanto assim que Baudelaire compusera primeiro as prosa as Flores do Mal-e só mais tarde, depois de retificar a justeza das análises, as passara a verso, laboriosamente, com um dicionário de rimas!... De resto em França (acrescentou o estranho homem) não havia poetas. A genuína expressão da clara inteligência era a prosa. Os seus mais finos conhecedores preferiam sempre os poetas cuja poesia se caracteriza-se pela precisão, lucidez, sobriedade - que são qualidades da prosa; e um poeta tornava-se tanto mais popular quanto mais visivelmente possuía o gênio de prosador. Boileau continuaria a ser um clássico e um imortal quando já ninguém se lembrasse em França do tumultuoso lirismo de Hugo. (QUEIROZ. 1946. págs 31, 32)

Fradique nega a importância de Baudelaire. Caminha no sentido contrário a do narrador, que a todo momento faz a ligação entre o autor de As Flores do Mal e o de Lapidárias, dizendo que há entre essas duas obras pontos cruciais que as assemelham. De fato há em Lapidárias uma forma e uma temática que por vezes remontam poesias de Baudelaire ${ }^{6}$. E em sentido oposto há o contato com sua obra em prosa, suas cartas. O autor da obra, Eça de Queiroz, faz com que Fradique Mendes fique conhecido de seu público não por meio de sua obra poética, mas sim por meio de sua prosa.

O narrador no momento da explanação de Fradique sente-se indignado, classifica o novo

\footnotetext{
${ }^{6}$ Leva-se em consideração aqui a obra MENDES. Carlos Fradique (Antero de Quental). Versos - Textos breves. Lisboa: Edições 70. 1973.
} 
amigo um insolente, mas logo depois julga-se incapaz de defender o ponto de vista contrário ao de Fradique: "Tinha mil coisas, abundantes e esmagadoras, a contestar: mas não ousava, por não poder apresentá-las naquela forma translúcida e geométrica do poeta de Lapidárias” (Ibidem, pág. 33).

Parece-nos que Fradique se encaixa como objeto de seu próprio discurso, objeto defendido em seu manifesto, já que para ele o poeta que merece louros é aquele que tem em si a alma de prosador. Carlos é um exímio orador e depois se torna conhecido pelas suas cartas bem estruturadas e bem argumentadas. Logo, encaixa-se na categoria "poeta que possui gênio de prosador". Esse Fradique que deixa seus narradores afoitos traz em si o mistério, por isso as especulações narrativas:

\begin{abstract}
Essa personagem queirosiana (levando também em consideração as outras mãos em sua elaboração) traz em A Correspondência a característica da especulação, como diz um de seus efabuladores no prefácio de $O$ Único filho de Fradique Mendes: "Um dos grandes temas, entre muitos, que Eça de Queiroz deixou à nossa livre e permanente especulação - foi o caso de Fradique Mendes. Ou antes: o mistério de Fradique Mendes" (VIDAL. 1950. pág. 7).
\end{abstract}

Poderíamos dizer especulação, exploração ou apropriação. Na obra em que Fradique é feito definitivamente pessoa, a personagem é construída por meio de histórias sobrepostas. Explicamos: a história de Fradique Mendes é conhecida pela narrativa elaborada por Marcos Vidigal: "pareciame a imprudente exageração de um ilhéo que me queria intrujar...” (QUEIROZ. 1946. pág. 18). O narrador fica com uma imagem idealizada do poeta. Após conhecê-lo um pouco conta sobre a história deste homem ao amigo J. Teixeira d'Azevedo: “[...] espantei J Teixeira d'Azevedo com um Fradique idealizado, em que tudo era irresistível, as ideias, o verbo, a cabaia de seda, a face marmórea de Lucrécio moço, o perfume que esparzia, a graça, a erudição e o gosto!”.

Teixeira acha-o postiço e teatral. Depois nos é apresentado o Fradique caracterizado pelo autor do Portugal Contemporâneo (pág. 62), e logo após o de Ramalho Ortigão (pág. 63), depois o poeta da Morte de D. João e da Musa e Carlos Mayer, que nos remete a uma fala no mínimo atemporal: "[a Fradique] só lhe falta uma ideia que o alugue, para viver e governar lá dentro" (pág. 64). Parece-nos que José Eduardo Agualusa resolveu lhe dar essa ideia. Com isso temos um Fradique que flana de "boca em boca" na construção de sua biografia. Logo, existe um conjunto de criações dentro da própria criação do narrador em A Correspondência. Há aqui um homem que é constituído por parcelas de verdades, não há verdades inteiras, há trechos de várias verdades e olhares.

Assim como Fradique flana dentro de seu próprio texto, constituído por partes de verdades, abre precedente para, assim como diz Vidal, ser especulado. Ser construído por outras partes de verdade em outros textos e por outros autores. O Fradique de A Correspondência é repleto de 
aparições quase divinas, caracterizações eclesiásticas estão em volta deste ser. Quando o narrador o encontra na ocasião de uma viagem ao Egito, todas as aparições são descritas com glórias: “[...] avistei eu no terraço, estendido numa comprida cadeira de vime, com as mãos cruzadas por trás da nuca, o Times esquecido sobre os joelhos, embebendo-se todo de calor e de luz? Fradique Mendes.” (QUEIROZ. 1946. pág. 38).

O poeta parece habitar os mais íntimos desejos desse narrador, que anseia encontrar o gozo, recebê-lo com um "sorriso de transbordante prazer". Chega a, em um momento de devaneio, aparecer para ele como o deus Júpiter:

Assim se tornava verossímil que aquele homem, cuja face cheia de majestade e força serena reproduzia as feições com que Júpiter se revelou à Escola de Athenas - fosse na realidade Júpiter, o Tonante, o Fecundador, pai inesgotável dos Deuses, criador da Regra e da Ordem (Ibidem, pág. 42).

Fradique traz de suas experiências de viagens um arcabouço de conhecimento considerável, também por conta de toda sua educação no decorrer de sua infância e adolescência. Conhece cada ritual, cada máscara, cada dança. Chega ao ponto de surpreender seu companheiro de viagem, o narrador da biografia:

Essa saudação oriental em que os dedos três vezes batem a testa, a boca e o coração. E como eu, rindo, lhe invejava aquela intimidade com um "homem de túnica verde e de mira persa: - É um Ulemas de Bagdad, disse Fradique, de uma casta antiga, superiormente inteligente... Uma das personalidades mais finas e mais sedutoras que encontrei na Persia." (QUEIROZ. 1949. pág. 52)

Como aquele que perambula pela sala da própria casa, Fradique anda pelo Egito, Pérsia e outros países do Oriente Médio. Tudo a ele parece ser vitrine conhecida. E é de bom tom, colocando-se sempre um patamar acima de seu amigo narrador, explicar os fatos e história pra um leigo. No passo contrário, em Agualusa, está o Fradique que é apresentado à Africa. Quando em carta a Madame Jouarre, de junho de 1868, descreve um momento dito ritualístico para quem se atreve a ir a Luanda:

Arcénio de Carpo explicou-me então que ser apresentado à senhora Gabriela Santamarinha é em Luanda quase um ritual iniciático. "Á nossa volta muita gente aposta que vossa excelência vai fraquejar", disse. "Rrespire fundo e venha. Quando estivermos juntos dela não respire". (AGUALUSA. 2000. pág. 23)

Fradique parece se posicionar de maneira passiva frente a África. Ainda finaliza esta mesma carta com: "um país que me surpreende todos os dias". Acreditamos que o que causa essa diferença possa ser a ênfase e proposta dos diferentes textos; já que entendemos que Eça levanta uma fração 
para que esta sirva como representante de uma geração, levante, como dito, uma espécie de manifesto da prosa realista, a figura central aqui é de fato o homem Fradique Mendes.

Em Agualusa acreditamos que o foco não seja mais aquele homem (por mais que ele represente a figura do império colonizador), mas sim a terra em que ele se "atreve" a entrar. O objetivo em Nação Crioula não é desmitificar o homem, mas o local. Mostrar que até mesmo para um viajante experiente como Fradique Mendes, a África pode esconder segredos.

Por mais que Fradique inicialmente se comporte de maneira passiva frente à cultura africana, em determinada parte do romance de Agualusa este começa a se ambientar e a defender a causa antitráfico negreiro. "Defensor de causas" como afirma Fernando Venâncio, Fradique parece também em sua biografia (após sutilmente levantar um manifesto a favor da prosa realista) um homem de causas, pois tornar-se defensor de uma seita religiosa:

E Fradique, com toda singeleza, confessou que se demorara tanto nas margens do Eufrates por se achar casualmente ligado a um movimento religioso que, desde 1849 , tomava na Persia um desenvolvimento quase triunfal, e que se chamava o Babismo. Atraído para essa nova seita por curiosidade crítica, para observar como nasce e como se funda uma religião, chegara pouco a pouco a ganhar pelo Babismo um interesse militante - não por admiração à doutrina, mas por veneração dos apóstolos (QUEIROZ. 1946. pág. 52)

Nos contatos que o narrador tem com o poeta, parece-nos que há lentamente um processo de "fradiquização" desse Eça (narrador): "na nossa copiosa correspondência desses anos privei sempre, sem reserva, com a inteligencia de Fradique - e ininterruptamente assisti e me misturei à sua vida pensante (Ibidem, pág. 65).

Assim como Fradique deambula pelos lugares mais contemplativos da terra, o narrador parece acompanhar esse movimento, para em alguns momentos encontrar, sempre coincidentemente, com seu "incomparável amigo". Após dois contatos intensos com o poeta, o narrador, a partir do capítulo IV diz que o contato entre os dois começou a ser feito por cartas, já que ele e seu amigo sempre estavam conhecendo lugares novos pelo mundo:

Durante anos não tornei a encontrar Fradique Mendes, que concentrara as suas jornadas dentro da Europa Ocidental - enquanto eu errava pela América, pelas Antilhas, pelas Repúblicas do Golfo do México. E quando a minha vida enfim se aquietou num velho condado rural de Inglaterra, Fradique, retomado por essa "bisbilhotice etnográfica" a que ele alude a uma carta a Oliveira Martins, começa a sua longa viagem pelo Brazil, aos Pampas, ao Chile e à Patagônia. [...] Quase todos os três meses trocávamos uma carta - cinco ou seis folhas de papel que eu tumultuosamente atulhava de imagens e impressões, e que Fradique miudamente enchia de ideias e de fatos. (QUEIROZ. 1946. pág. 61)

De maneira emblemática, a "intimidade intelectual" entre Fradique e o narrador se dá em 
Paris, também em uma coincidência, em 1880. Dessas tardes em conversa com o poeta, o narrador, além de discutir temas relacionados ao Universo, à moral etc, percebe em determinada situação que seu "íntimo amigo" passa por uma desilusão amorosa e a partir disso o narrador busca em correspondências trocadas entre Fradique e alguns conhecidos, e nas próprias discussões acaloradas sobre o tema, a negação completa do amor, da inebriação e da emoção. Para Fradique (opinião compartilhada pelo narrador), a emoção e o amor são como a argila, moldável, volúvel e frágil:

Numa carta a Oliveira Martins, de 1883, Fradique diz: "O homem, como os antigos reis do Oriente, não se deve mostrar aos seus semelhantes senão única e serenamente ocupado no ofício de reinas - isto é, de pensar". Esta regra, dum orgulho apenas permissível a um Spinosa ou a um Kant, dirigia severamente a sua conduta. Pelo menos comigo assim se comportou imutavelmente, através da nossa ativa convivência, não se abrindo, não se oferecendo todo, se não nas funções da Inteligência. Por isso talvez, mais que nenhum outro homem, ele exerceu sobre mim império e sedução (QUEIROZ. 1946. pág. 69)

Ambos se colocarem contra o sentimento de amor, de entrega, de fato corrobora o discurso do próprio poeta quando sutilmente levanta o manifesto em prol da prosa resliata. A observação severa da realidade, sem a inebriação das emoções é o que, para eles, marca a evolução do homem. A ideia de amor é tratada de maneira singular pelos diferentes efabuladores. Vidal traz como mote de seu texto o resultado de uma união amorosa (Fradique e Lobiska); Agualusa reproduz algumas cartas do poeta em que há claras manifestações de emoção amorosa.

Já na segunda parta de A Correspondência, em carta à Carlos Mayer, quando da discussão sobre algumas figuras canônicas e suas importâncias para história da arte, Fradique Mendes disserta, e para nós levanta aqui outro tipo de manifesto, militante, sobre a questão da educação. Critica a introdução dos cânones, de discursos feitos e repetidos durante os séculos.

A isto, oh, Carolus, se chama educar! A criança, desde sua primeira "seleta de leitura" ainda mal soletrara, começa a absorver esta camada do Lugar-comum camada que depois todos os dias, através da vida, o Jornal, a Revista, o Folheto, o Livro lhe vão atochando no espírito até lho empastarem todo em banalidades, e lho tornarem tão inútil para a produção como um solo cuja fertilidade nativa morreu sob a areia e pedregulho de que foi barbaramente alastrado. Para que um Europeu lograsse ainda hoje ter algumas ideias novas, de viçosa originalidade, seria necessário que se internasse no Deserto ou nos Pampas; e aí esperasse pacientemente que os sopros vivos da Natureza, batendo-lhe a inteligência e dela pouco a pouco varrendo os detritos de vinte séculos de Literatura, lhe refizessem uma virgindade.[...] Depois de dois anos de vida selvagem entre o Hotentote nu movendo-se na plenitude lógica do Instinto, - que restará ao civilizado de todas as suas ideias sobre o Progresso, a Moral, a Religião, a Indústria, a Economia Política, e Sociedade e a Arte? Farrapos. (QUEIROZ 1946. págs. 72, 73).

Por mais que Carlos tenha sido educado tendo um contato direto, como dito, com as 
principais obras de arte da humanidade, há um ponto nesse processo que parece fazer com que este homem ganhe autonomia para, principalmente, contestar tudo aquilo que lhe foi "imposto" como padrão de literatura e arte. Fradique, por mais que seja um homem moderno, e o é definitivamente, um cidadão do mundo, homem que absorve todas as culturas do mundo, que passam a nele habitar e a exteriorizar, este homem é também um crítico do seu próprio tempo, um homem inquieto e problematizador. Fradique levanta a questão da educação com muita propriedade, pois conhece, após viagens por toda parte do planeta, que aquilo que se aprende na Europa Ocidental acaba por não ter valor algum em, por exemplo, uma tribo de nômades do Oriente Médio.

Parece-nos que as amarras do "lugar-comum" foram tiradas de Fradique, ou melhor, parece Fradique ter se libertado das amarras do lugar-comum quando percebeu o valor relativo do cânone, por isso relativiza sua importância, por isso pode criticar com propriedade de profundo conhecedor (e às vezes militante) das novas filosofias, das novas religiões, das novas comunidades aquilo que fora injetado por mais de vinte séculos na Europa, e faz parte da educação de todo bom homem europeu.

O cotidiano é alvo de Carlos: os jornais, as revistas, os livros que formam o bom homem europeu são mentiras repetidas, por isso se tornam verdade, segundo ele, ao homem que não conhece o que há além das fronteiras de seu país. Defende a ideia de um processo de virginização do homem europeu. Ou apagamento daquilo que fora escrito durante toda a história - talvez a busca pelo bom selvagem. A criança, como o poeta diz, em seu processo de educação passa a perder aquilo que é deveras importante, sua criatividade, pois nela se vão injetando fórmulas prontas.

A negação do cânone, para Fradique Mendes é a criação definitiva de um novo homem, nem superior nem inferior, um homem que possa enxergar que a verdade pode não existir, o que habitará nesse novo mundo seriam verdades e todo homem teria a consciência disso: "recolher com cuidado o ensino ou a parcela de verdade que exista nos seus refolhos" (QUEIROZ. 1946. pág. 77).

Fradique é a prova "viva", o exemplo de que verdades podem transitar em uma mesma realidade, pois há nele a construção de um homem por múltiplas mãos, cada uma delas com intuitos distintos (Eça, Vidal, Agualusa e Fernando), mas que trabalham suas verdades na figura daquele que representa um novo olhar, mesmo que reconhecidamente (Fradique) conheça suas próprias limitações:

Não sendo por um sábio, nem um filósofo, não posso concorrer para um melhoramento dos meus semelhantes - nem acrescendo-lhes o bem estar por meio da Ciência, que é uma produtora de riqueza, nem elevando-lhes o bem-sentir por meio da Metafísica que é uma inspiradora de poesia. [...] Só portanto me resta ser, através da ideias e dos fatos, um homem que passa, infinitamente curioso e atento. (QUEIROZ. 1946. pág. 77) 
Fradique, por ter um olhar aguçado e atento, um olhar de poeta, o "poder de definir", produzia, segundo o narrador, arte de primeira estirpe. Há em A Correspondência de Fradique Mendes um trecho que nos remete a uma leitura ambígua - que para a análise do que representa Fradique na obra, e do que este também acaba por representar para seus futuros efabuladores - se faz no mínimo pertinente.

Em momento de discussão, os amigos Fradique, o narrador e outros se encontram na casa do poeta buscando qual seria a mais plausível definição de Arte. $O$ poeta define sabiamente (segundo o narrador) da seguinte maneira: "A arte é um resumo da Natureza feito pela imaginação". Logo após o narrador cita a fala de um homem não nomeado no texto: “[...] se o bom Deus, um dia, compadecido das nossas hesitações, nos atirasse lá de cima, do seu divino ermo, a final explicação de Arte, nós ouviríamos ressoar entre as nuvens, soberba como o rolar de cem carros de guerra, a definição de Fradique!"' (Ibidem, pág. 83)

Em uma leitura rápida e até mesmo descuidada certamente poderia se afirmar que o homem que cita tal afirmação está dizendo que a definição de Fradique é a correta, é aquela que o "bom Deus" enviaria. Há aqui primeiramente, ainda partindo dessa leitura rasa, que se a opinião de Fradique é a mesma que a de Deus há de fato a colocação deste poeta, como se vê a tentativa durante toda a biografia, em um patamar que está acima de meros mortais.

Escapando a isso, podemos ler o texto como se a definição divina de arte fosse aquilo que se entende como a definição do que é ser Fradique Mendes. Este representaria a própria arte, o sempre novo, a criação, a não-verdade, a sugestão, ao mesmo tempo a realidade, a natureza. Produzir arte é produzir Fradique Mendes. Talvez isso nos leve a importância dessa personagem para os futuros efabuladores, a representabilidade, no âmbito da arte, que essa personagem estabelece, já que a arte é ao mesmo tempo única como Arte e múltipla como criação, elementos.

Usar a arte em "pessoa" para criar uma África consistente e que sirva como quebra de paradigma, Agualusa o faz. Se utilizar da mesma personagem Arte para criar um romance que seja paródia dele mesmo, que provoque o gênero ensaio por meio das ações psíquicas tumultuosas de um narrador, que do mesmo modo de A Correspondência, se entregue a esta Arte. Venâncio o faz.

Ainda que o crítico Fernando Venâncio afirme que " ele poderia no máximo ser um inglês com umas tintas francesas, tintas de italiano, mas português muito pouco", e Fradique Mendes, mesmo sendo feito, segundo suspeitas do próprio crítico, para não ser português, o narrador de $A$ Correspondência, em determinado momento da apresentação de seu amigo, parece tentar encaixálo em sua pátria, ou melhor, reencaixá-lo, já que o poeta se comporta como visitante em seu próprio país, estando mais fora do que dentro dele. 
Desde 1880 os seus movimentos pouco a pouco se concentraram em Paris e Londres - com exceção das "visitas filiais" a Portugal: porque apesar da sua dispersão pelo mundo, da sua facilidade em se nacionalizar nas terras alheias, e da sua impersonalidade crítica, Fradique foi sempre um genuíno português com irradicáveis traços de fidalgo ilhéo. (Ibidem, pág. 92)

Fradique é colocado como filho de Portugal. O narrador afirma que "O mais puro de seu interesse deu-o sempre aos homens e às coisas de Portugal" (Ibidem, pág.92). A relação entre Fradique e o país que lhe deu origem é bastante complexa. Como um país como Portugal, que no século XIX já é colocado como periferia da Europa, um lugar pacato, católico e atrasado, poderia ter produzido um homem como Fradique Mendes. E o que pode significar seus "traços irradicáveis de fidalgo?" Certamente o poeta de Lapidárias remonta alguns mitos criados pelo português. O narrador traz o homem conquistador, em Fradique há conquistas e descobertas, e até mesmo as posses (terras), daquilo que foi o País no século XVI, quando de suas conquistas pela África, Ásia e América. É essa a trajetória de Fradique Mendes.

O narrador que se diz Eça o insere nos três continentes, com um olhar conquistador e viril, um mote elaborado e reelaborado no decorrer do tempo, autores que "cantando espalha[riam] por toda parte, se a tendo [lhes] ajudar o engenho e a arte" (Camões. 2000. pág. 17)

Remontar um Fradique "conquistador de novas terras" é, a nosso ver, ao mesmo tempo trazer novamente um Portugal das conquistas e até mesmo reconfigurar um D. Sebastião (também conquistador). Fradique Mendes canaliza em si mitos que remontam a um País de glórias e de cultura hegemônica. Mas por se tratar de um homem moderno essa conquista não vem por meio de lutas e guerras, ela aparece por meio da própria figura ativa da personagem.

Há um movimento circular durante das efabulações da figura Fradiquiana. Com Eça há um homem que sai para o mundo, conquista-o (lugares e pessoas com as quais toma contato), critica culturas alheias, vive-as, nacionaliza-se em cada país que visita. Em Vidal há uma pequena curvatura na constituição de Fradique, deixa de pertencer a um olimpo e passa a ganhar características mais humanas. Em José Eduardo Agualusa há uma curvatura quase que completa nesse processo, pois não mais tem um caráter ativo, deixa por alguns momentos de ser um deus, representante de uma geração, e passa a ganhar tintas da passividade (por mais que contraditoriamente seja o romance em que há um maior engajamento da personagem). Não é em Nação Crioula Fradique quem conquista a África, ele é deliberadamente conquistado pela magia que as terras africanas oferecem. Terra que parece retirar a máscara para esse viajante, principalmente na figura de Ana Olímpia, que parece tomar as rédeas das decisões e da narrativa como um todo.

Em Fernando Venâncio há uma aproximação daquele português com a sua pátria (espião na serviço da coroa - herói). Fradique parece fazer "as pazes" com o seu lugar, ou melhor a sua figura 
rememorada por intermédio de seu sobrinho parece voltar às mentes de seu povo, principalmente de sua história, na própria imagem final da narrativa, quando as duas descendências fradiquianas se encontram no aniversário de 25 anos da Revolução de Abril (metáfora do novo e da mudança).

Uma personagem que ao mesmo tempo é dinâmica e toma as decisões de sua vida por si mesma, mas mostra, como um D. Juan, uma queda pelas mulheres. Várias fizeram parte da vida desse poeta português. Como foi tratado acima, há visões divergentes em relação à figura da mulher nas várias "frações" de Fradique. Visto a diferença entre o dOs Mistérios frente o de Nação Crioula, há em A Correspondência de Fradique Mendes a mostra direta e clara de que o poeta de Lapidárias admira demasiadamente a figura da mulher. E diz aqui Mulher, como ser divino, mitológico, sagrado:

A influência deste "feminino" foi suprema na sua existência. Fradique amou mulheres; mas fora desses e sobre todas as coisas, amava a Mulher. A sua conduta para com a mulheres era governada conjuntamente por devoções de espiritualista, por curiosidades de crítico, e por exigências de sanguíneo. [...] Fradique considerava-as como "organismos" superiores, divinamente complicados (Ibidem, pág. 103, 104)

De certo que em todas as efabulações há a presença de mulheres na vida dessa personagem, e não somente a presença, mas uma presença decisiva para que a narrativa de algumas (Vidal e Agualusa) tivesse passagens substanciais e até mesmo modificações de enredo, de caminho narrativo.

Vidal remonta a vida dessa personagem dando a ele a oportunidade de uma interação real com uma mulher, o mesmo faz, e de maneira radical, a nosso ver, Agualusa, quando constrói uma fração de Fradique que se envolve por completo com Ana Olímpia. Mulher de força e caráter, gênio ativo que faz com que a linha narrativa de Fradique se modifique, pois o "homem do século" é motivado pelas campanhas da mulher a realmente se engaja por uma causa, a do tráfico negreiro (de maneira não superficial, como pode parecer no engajamento do Fradique queirosiano).

Posteriormente, quando formos tratar em específico a obra Nação Crioula, trabalharemos uma relação que parece ser pertinente quando se diz respeito à figura desta mulher (Ana Olímpia) e a característica aqui tratada sobre a "passividade" de Fradique.

Muitas vezes Fradique aparece com distintos olhares nas diferentes efabulações, vezes um olhar analítico frente a mulher, como acontece em Os Mistérios e em A Correspondência, vezes com um olhar bajulador e de simples amantes, como em Agualusa e Venâncio (onde Martinho parece reencontrar a veia "D. Juan" de Fradique).

Esta personagem que o narrador de A Correspondência nos apresenta é tão ligada a figura feminina que levanta até mesmo uma teoria sobre ela: "Havia a 'mulher d'esterior', flor de luxo e de 
mundanismo culto; e havia a 'mulher d'interior', a que guarda o lar, diante da qual, qualquer que fosse seu brilho [...] excluindo toda a investigação experimental (Ibidem, pág. 104).

O bon vivant Fradique Mendes coloca sua faceta de aproveitador de mulheres em uma carta que envia a Madame de Jouarre, quando diz:

\begin{abstract}
Na presença, porém, daquelas que se "exteriorizam" e vivem todas no ruido e na fantasia, Fradique achava-se tão livre e irresponsável como perante um livro impresso. "Folhear o livro, anotá-lo nas margens acetinadas, criticá-lo em voz alta com independência e veia, levá-lo no coupé para ler à noite em casa, aconselhá-lo a um amigo, atirá-lo para um canto percorridas as melhores páginas - é bem permitido, crio eu, segundo a Cartilha e o Código" (Ibidem, pág. 105)
\end{abstract}

$\mathrm{O}$ poeta parece distinguir e atribuir valores a essas determinadas classes de mulheres. A primeira seria como "uma carta fechada", em que não deveria nenhum homem descobrir os segredos, somente respeitá-la. Já a segunda é colocada como pessoa a ser descoberta, e nesse processo fica claro que pode haver o desinteresse: "atirá-lo para um canto percorridas as melhores páginas”. Mas há aqui uma contradição.

Fradique pode parecer tradicional e preconceituoso, mas o que há de mais interessante, uma carta lacrada ou um livro prestes a ser descoberto? Sem dúvidas que um livro é de maior serventia, maior público, maior formação do que uma carta ou bilhete lacrados.

Por mais que Fradique possa ser visto, mesmo no século XXI, com olhares modernos e contemporâneos, para o século XIX carregava um olhar para com a mulheres bem coerente com sua época. Acima pareceu-nos menosprezar aquela que vive suas viagens, seus amores, suas delícias, e pareceu-nos evidenciar aquela que enclausura dentro de si seus desejos e que se fecha entre as paredes de seu lar, para seu marido e filhos.

O fração fradiquiana desse narrador que se diz Eça de Queiroz se distancia um pouco dos demais nesse olhar para com as mulheres. Havia em Fradique, como diz o narrador, "com toda a leviana altivez da mocidade, lançava este rude programa de conduta:' - Os homens nasceram para trabalhar, as mulheres para chorar, e nós, os fortes, para passar friamente através!... "'. (QUEIROZ. 1946. pág. 107).

Coloca-se em um patamar, como até aqui trabalhado, quando se diz respeito a essa efabulação, acima dos homens comuns, como um deus. E o que cabe a mulher seria apenas a solidão e o sofrimento, subentendemos um sofrimento provocado por amor, por um desejo contido. Ser forte aqui seria de fato não sofrer por amor, não sofrer a dependência que um amor pode causar.

Parece se colocar como homem acima de todo e qualquer sentimento. Um mármore altivo. Escultura de deus apoteótico. Apolíneo, por mais que viva dionisicamente. A mulher seria um objeto de desejo, como veremos em cartas, quando esta é colocada pelo autor como ser idealizado, 
como se ela pudesse por alguns instantes fazer parte dos seres desse olimpo habitado por homens que estão acima de todo e qualquer sentimento.

Pode parecer contraditório, mas é plausível no sentido de que um homem sendo deus pode transitar em mundos diversos, sem se preocupar com essa contradição. Pode ser forte e não sentir, ou pode sentir demasiadamente. E é nesse segundo plano que Agualusa, a nosso ver, se encaixa, no "sentir" demasiadamente.

O autor angolano parece explorar essa vertente dionisíaca do amor e até mesmo do engajamento, pois há nessa efabulação uma maior paixão, tanto para com a mulher (Olímpia) como para com a própria causa escravista. O que percebemos é que Fradique Mendes, levadas suas devidas proporções e motivações nas determinadas efabulações, carrega em si o equilíbrio entre as forças dionisíacas e apolíneas:

Mas se a embriaguez é o jogo da natureza com o homem, a criação do artista dionisíaco é o jogo com a embriaguez [...] o servidor de Dionísio deve estar em estado de embriaguez e ao mesmo tempo permanecer postado atrás de si como um observador. Não é na alternância entre lucidez e embriaguez, mas na sua simultaneidade, que se encontra o estado estético dionisíaco. (NIETZSCHE. Frag. Post., primavera de 1888, 14 [23]; cf. Outono de 1887, 9 [102])

No decorrer da narrativa biográfica em que é apresentado Fradique Mendes, inicialmente há um homem que se encaixa em carácter apolíneo, no decorrer de sua vida parece ganhar gradativamente caracteres dionisíacos, há nesse mesmo homem um equilíbrio entre a embriaguez e a lucidez. Se fôssemos gerar um gráfico sobre essa relação apolínea e dionisíaca, tendo como base as efabulações, haveria uma linha crescente, partindo do apolíneo e chegando ao ápice do dionisíaco em Agualusa, mantendo-se estável, cronologicamente, até Fernando Venâncio - que transfere essa instabilidade para a própria personagem "Martinho".

Agualusa trabalha um Fradique mais velho, que aponta em suas cartas ter por volta de 50 anos. E o próprio narrador de A Correspondência afirma que "brota, tépida e generosamente [em Fradique] o leite da bondade humana". Parece que há na fração agualusiana uma maior maturidade para talvez entender com mais paixão, com mais entrega, os valores do amor e das causas.

E principalmente em relação a essas "causas" há uma distância grave entre as efabulações queirosianas e exatamente as agualusiana e venanciana. Nas primeiras parece-nos que há uma militância fajuta, no sentido de que alguma manifestação é observada, vivida até certo ponto, sem que a lucidez (apolíneo) perca lugar. Parece-nos um observador que por vezes, e falsamente, embarca em alguma causa, por um curto tempo. Ou a ajuda pode vir "marcada a lápis": 
resgatar: mas nunca houve mal, por ele conhecido, que dele não recebesse alívio. Sempre que lia por acaso, num jornal, uma calamidade ou indigência, marcava a notícia com um traço a lápis, lançando ao lado um algarismo - que indicava ao velho Smith o número de libras que devia remeter, sem publicidade, pudicamente. (QUEIROZ. 1946. pág. 109)

Há uma distância entre esse Fradique e os problemas e as causas universais. Trata-se de um filósofo que discute e disserta sobre grandes problemas do mundo e, quando pode ou lhe convém, ajuda de longe com sua "caridade" (libras). Posiciona-se diferente da grande causa acolhida pela fração de Agualusa (o tráfico negreiro) e até mesmo pelo Fradique venanciano, pois é rememorado pela causa implícita da Revolução de 25 de Abril e do Império português.

Entre essas figuras e efabulações comentadas, parece-nos que há também uma diferença marcante. Em relação ainda às causas, ao engajamento, cumpre-nos dizer que assim como o engajamento está para a prática em Agualusa, este mesmo engajamento está para a teoria em Queiroz. Há no livro de Eça um narrador que disserta sobre as reflexões de Fradique no tocante a questão das diferenças de classe. Um homem que observa, sem sair de seu olimpo, essa diferença, e ainda promove a caridade, como visto. "[...] cada vez um se torna cada vez mais o lobo do seu semelhante, homo homini lupus" (Ibidem, pág. 111). Aqui há uma fração que vê essa relação com um olhar de crítico, de estudioso das relações humanas. Ali, em Agualusa, que se entrega e vive essa relação.

Arcénio rui-se: $<$ pergunta se queremos comprar um escravo $>$. Recuei indignado e o garoto lançou-se aos meus pés chorando e lamentando-se. $<<$ Se não o comprarmos, eles matam-no〉>, explicou Arcénio: <<era exatamente isso que eu lhe queria dizer. Ao comprar um escravo estou a salvar-lhe a vida〉>. (AGUALUSA. 2000. pág. 63)

Quando o narrador disserta sobre a morte de Fradique, após comentar que este fora enterrado próximo de Balzac, também agudo observador da sua realidade, fala sobre uma crônica escrita sobre seu amigo, em que o autor (“erudito moralista que assina Alceste na Gazeta de Paris) afirma que fora indolente e indiferente, que fora mero observador de causos. Em contra posição, o narrador logo se coloca, dizendo que Fradique fora um homem de ação, de paixão e de tenaz labor.

Há em muitos momentos da obra uma contradição entre as imagens referentes a Fradique, e se negativa, como a de Alceste e a de J. Azevedo, logo o narrador se coloca contra, argumentando com algum caso da vida do poeta. O fato é que Fradique, durante essa primeira parte da obra, é conhecido pelos olhos alheios. Assim depois se constrói Fradique por olhos alheios de seus efabuladores. Trata-se então de um indolente ou de um apaixonado?

A vida de Fradique parece-nos ser composta por um grande álbum de fotografias (álbum que talvez realmente apareça na obra de Venâncio, documento que está em posse do dr. Cristiano). 
Em cada uma delas Fradique está em um lugar, cada uma delas pertence a um determinado tempo, em cada uma delas o poeta está acompanhado de figuras ilustres. Mas o detalhe que nos chama mais a atenção é que cada uma dessas fotos é tirada por pessoas diferentes.

Uma mesma linha temporal composta por fotógrafos diferentes, e cada um dá o foco e a perspectiva que lhes convier. Como diz ainda o narrador de A Correspondência: "O cronista da Gazeta de Paris acerta porém, singularmente, afirmando que desse duro obreiro não resta uma obra. Impressas e dadas ao mundo só dele conhecemos com efeito as poesias das Lapidarias [...]” (Ibidem, pág. 115).

Após isso o narrador começará a contar sobre o espólio de Fradique, que estava em poder de Varia Lobriska (personagem revisitada por Vidal e Venâncio). Há certamente aqui o precedente para que sempre novos documentos atribuídos a Fradique apareçam, já que este nos deixou oficialmente somente Lapidárias. Nisso se estrutura todo o jogo das efabulações fradiquianas, já que se trata de um "autor" que pouco deixou, e que quando foi apresentado mostra que há um espólio com diversos materiais, porque não dar continuidade em todo esse processo narrativo, ainda mais se tratando da figura vezes excêntrica, vezes engajada, vezes irônica que é Fradique Mendes?

Além da falta de publicações, há, em todo processo de criação dessa personagem, um caráter "secreto" daquilo que se atribui a Fradique. Já em A Correspondência o narrador deixa claro que Varia Lobriska não tornará público o espólio fradiquiano, em carta a Eça (narrador) quando de seu pedido de alguns documentos para estudo:

\footnotetext{
"Os papéis de Carlos Fradique tinham-lhe sido confiados, a ela que vivia longe da publicidade, e do mundo que se interessa e lucra na publicidade, com o intuito de que para sempre conservassem o caráter íntimo e secreto em que tanto tempo Fradique os mantivera: e nestas condições o revelar a sua natureza seria manifestamente contrariar o recatado e altivo sentimento que ditara esse legado..." (QUEIROZ. 1946. pág. 118)
}

Contraditoriamente, esse caráter secreto e íntimo fez com que vários documentos, dos mais diferentes efabuladores, surgissem. Pois o precedente foi aberto, já que é secreto, qualquer documento que seja coerente com a proposta fradiquiana pode ser atribuído ao poeta das Lapidárias, engendrando e indo além da função-autor foucaultiana.

O subtítulo da obra de Agualusa é "A Correspondência Secreta de Fradique Mendes", logo traz à tona o desconhecido sobre a "natureza" dos documentos legados. Vidal traz também algo desses documentos, também Venâncio vasculha por resquícios desse espólio, e de outros (em busca dos Esquemas de Fradique).

Portanto, entendemos que dizer que não serão divulgados os segredos sobre a vida desse "grande homem", em A Correspondência, é o mesmo que dizer: serão divulgados tais segredos ao 
bel prazer de efabuladores, respeitando uma coerência estabelecida da primeira fração fradiquiana por mais que Eça e os coautores de Fradique não tenham, teoricamente, a intencionalidade de continuar esse processo.

No próprio trecho biográfico deixado por esse narrador, já há provocações e inferências de personagens sobre o que haveria de importante nesse espólio secreto, como a opinião de J Teixeira de Azevedo e outros que "julgam que nesses papéis existe um romance de realismo épico" (ibidem, pág. 119). Já Ramalho Ortigão "inclina a crer que os papéis de Fradique contêm Memórias porque só as Memórias se pode coerentemente impôr a condição de permanecerem secretas." (Ibidem, pág. 120).

É neste momento das abstrações das personagens, no tocante a qual seria o teor do espólio de Fradique, que o narrador ironicamente provoca algo inquietante naquele que lê Fradique após ter o conhecimento de tudo aquilo que essa personagem provocou até o século XXI: "E afirmo afoitamente que nesse cofre de ferro, perdido num velho solar russo, não existe uma obra - porque Fradique não foi verdadeiramente um autor.” (Ibidem, pág. 120).

No decorrer do tempo, em suas efabulações, podemos afirmar, e como visto em Foucault (2009), Fradique não só se torna um autor, como extrapola uma função ator, já que nele se misturam, e intercalam o autor que promove um texto ficcional, fora de tudo aquilo que diz respeito a vida desse autor, juntamente com uma biografia onde tudo o que acontece se torna mote para uma nova efabulação.

Nas palavras de Foucault, "uma função autor para que um "recibo de lavanderia" seria, sim, de extrema importância para qualquer estudo sobre a vida desse "autor"”. Como o próprio narrador de A Correspondência diz: "faltou-lhe ainda a arte paciente [...] de encarnar suas ideias". Logo, trabalho resgatado e tomado pra si pelos efabuladores, que definitivamente encarnam as ideias de Fradique, além de conjecturar sobre a vida do "português do século". Portanto, o caráter secreto do espólio fradiquiano faz com que se fale sobre ele.

$\mathrm{O}$ fato de haver todo um trabalho escrito atribuído a Fradique, e o fato de ninguém ter inicialmente acesso a isso (e levando em consideração os conhecimentos das efabulações), faz com que um trecho em específico da primeira parte de A Correspondência tenha um outro valor interpretativo. Em conversa com Carlos, o narrador o indaga o porque de não escrever sobre a África. Questão que é prontamente respondida pelo poeta: “ - Para que?... Não vi nada na África que os outros não tivessem já visto.” (Ibidem, pág. 123). De certo que Agualusa se aproveita deste momento para conjecturar aquilo que realmente Fradique viu (e intensamente viveu) na África.

Mas a obra de Agualusa não entra em contradição quando é colocada frente esse "não vi nada na África que os outros não tivessem já visto”? Não. Pois há o espólio. Este acaba servindo como válvula de possibilidades para tudo aquilo que apareça e que possa ser atribuído a Fradique. 
Uma conversa com o narrador pode não conter a verdade sobre o que Fradique tenha visto na África.

Tudo na verdade pode estar no espólio, ou até mesmo nas cartas que o narrador que se diz Eça de Queiroz não publicou: “[...] nestes pesados maços das cartas de Fradique, escolho apenas algumas, soltas, dentre as que mostram traços de caráter e relances da existência ativa; dentre as que deixam entrever algum instrutivo episódio da sua vida [...]” (Ibidem, pág. 131).

Entendemos que de fato todo esse jogo pós-queirosiano não poderia ser previsto pelos criadores de Fradique, e sabemos que muito menos desejado por eles, mas ele existe. E só existe porque há elementos nessa primeira criação que abrem precedente para as futuras efabulações, e é o que estamos tentando mostrar no decorrer do trabalho. Se a verdade essencial das coisas, segundo o próprio Fradique, não consegue ser expressa com exatidão por meio da escrita, sobra aos efabuladores "mentiras" fradiquianas. "Porque o verbo humano, tal como o falamos, é ainda impotente para encarnar a menor impressão intelectual ou reproduzir a simples forma de um arbusto... Eu não sei escrever! Ninguém sabe escrever!” (Ibidem, pág. 123).

A forma para Fradique era demasiada importante em uma obra de arte, mas ela faria com que a essencialidade daquilo que se proporia expressar não se expressasse por completo. Há na explicação do narrador sobre a publicação das cartas que recebera de Fradique uma defesa, deste, pelo gênero epistolar, trata da forma e da essência daquilo que se quer transmitir:

Eis aí uma maneira de perpetuar as ideias de um homem que eu afoitamente aprovo - publicar-lhe a correspondência! Há desde logo essa imensa vantagem: - que o valor das ideias (e portanto a escolha das que devem ficar) não é decidido por aquele que as concebeu, mas por um grupo de amigos e críticos, tanto mais livres e mais exigentes no seu julgamento quanto estão julgando um morto que só desejam mostrar ao mundo pelos seus lados superiores e luminosos. Além disso uma Correspondência revela melhor do que uma obra a individualidade, o homem; isto é inestimável para aqueles que na terra valeram mais pelo caráter do que pelo talento. Acresce ainda que, se uma obra nem sempre aumenta o pecúlio do saber humano, uma Correspondência, reproduzindo necessariamente os costumes, os modos de sentir, os gostos, o pensar contemporâneo ambiente, enriquece sempre o tesouro da documentação histórica. Temos depois que as cartas de um homem, sendo o produto quente e vibrante da sua vida, contém mais ensino que a sua filosofia - que é apenas a criação impessoal do seu espírito. (Ibidem, pág. 128).

Fradique Mendes parece dar o aval e o ponta a pé inicial para que suas "cartas secretas" sejam também publicadas. Ou para que se busque algo a ser publicado deste "homem do século". Já que não é aquele que escreve as cartas que escolhe o que será publicado, e sim um conjunto de amigos e críticos, podemos estender estes "amigos e críticos" os efabuladores que decidiram o que exteriorizar sobre a vida de Fradique, pois estes somente mostrariam os "lados superiores e luminosos" do homenageado. Somente as Correspondências poderiam revelar aquilo de mais 
íntimo de um homem, e assim como Eça, Agualusa percebeu isso, já que o intuito deste foi trabalhar com o caráter do homem português e não com o talento daquele que cria delimitado por uma forma.

Já Venâncio, com o objetivo contrário, trabalha não só o caráter, mas também, e vemos que principalmente, uma nova proposta de forma, um romance parodístico e metalinguístico. Ele, como nenhum outro, mescla as inovações de caráter daquilo que fora deixado por uma personagem como Fradique Mendes, com as inovações contemporâneas da forma e total convergência.

Nos efabuladores propostos há (em menor grau com Perry Vidal) sem dúvida, e como afirma Fradique, um "enriquecimento do tesouro da documentação histórica". Tanto para Agualusa, que trata do tráfico negreiro e da realidade Angolana no século XIX, quanto para Venâncio, em uma tentativa de revigorar e apaziguar as figuras portuguesas da pátria e da personagem queirosiana tratando liricamente a representação da Revolução dos Cravos, a produção literária pode ter, sim, um comprometimento e validade históricos.

Dentro da proposta moderna, é fato que a obra de Agualusa faz com que algumas reflexões deste narrador de $A$ Correspondência se tornem inverdades, e isso acontece, como será visto, por meio de um quase documento histórico. O narrador afirma em A Correspondência: "Um reino de África [...] será sempre uma terra bravia e morta, que, para lucro da Civilização, os Civilizados pisam e retalham tão desassombradamente como se sangra e se corta a res bruta para nutrir o animal pensante." (Ibidem, pág. 133). As cartas que o narrador decide publicar tem os seguintes destinatários: Visconde de A.T (1), Bento de S. (1), Madame de Jouarre (5), Mr. Bertrand B. (1), Oliveira Martins (1), Clara (3), Madame S. (1), Snr. E. Mollinet (1), Guerra Junqueiro (1) e Ramalho Ortigão (1).

Curiosamente esse Eça publica um número maior de cartas destinadas a Madame Jouarre, confidente de Fradique, e a Clara, sua amada, mesmo que durante a narrativa tenha afirmado, como visto, não se interessar e não ter tido contado com o lado sentimental de Carlos. Estudaremos a partir daqui quais são os teores dessas cartas: Fradique Mendes endereça a primeira carta para Viscode de A. T. como resposta para um bilhete que este tinha lhe deixado, pedindo, subentende-se, um conselho de alfaiate. Carlos lhe responde de maneira a que o homem devesse refletir, relativizando o conselho dependendo do propósito do homem.

Fradique parece fazer seu interlocutor refletir mesmo se tratando de algo aparentemente banal e sem importância. Faz nesta carta um jogo social, como se quisesse simplesmente "cobrir a nudez" o alfaiate mais próximo serviria, já que quisesse "citar com orgulho à porta da Havaneza, rodando lentamente para mostrar o corte ondeado e fino da cinta [...]", deveria procurar por Tomaz Cook. Fradique provoca uma reflexão constante de seus "interlocutores", como será visto também para outros destinatários. 
Na primeira carta endereçada à Madame de Jouarre - claro que não há aqui, acreditamos, um respeito à cronologia de escrita, como visto acima quando tratamos do tempo nas cartas Fradique começa a mostrar um olhar poético frente principalmente seu mais adorado objeto de análise, a Mulher. Há uma preocupação fina com as descrições, os detalhes, os modos, as vestimentas, até mesmo alguns pitacos de moda (como já acima tratou com Visconde de A. T.).

Há na carta a descrição de duas mulheres, Libuska (a que em Vidal lhe dará um filho) e uma mulher desconhecida que lhe chamou a atenção em um momento que passava com sua "namorada". Esta é pintada com cores escuras: "Libuska, que se move com o esplêndido peso de uma estátua! [...] voltei a cear ao pé da minha radiante tirana" (Ibidem, págs. 141/2). E a outra é, a leves pinceladas, pintada a cor pastel: "aqueles cabelos fabulosamente louros como o sol de Londres em dezembro - nem aqueles ombros descaídos, dolentes, angélicos, imitados de uma madona de Montegna" (Ibidem, pág. 141). Como um quadro expressionista que se tem uma visão primeira essa segunda mulher é mostrada, como impressão.

Fradique, mesmo bem acompanhado, como ele mesmo diz, se deixa invadir com a imagem desta outra mulher. E mulheres são de fato o objeto de desejo deste Dom Juan: "como pude eu abranger tanto, ao passar, com Libuska ao lado fiscalizando?” (Ibidem, pág. 141). Há na trajetória de Fradique o encontro com mulheres das mais variadas estirpes. Todos os efabuladores fazem com que esse poeta tenha de fato um olhar diferenciado para com a figura da mulher, e que também possa efetivamente se envolver com tais musas inspiradoras.

O mote desta mulher na carta a Madame de Jouarre se esvai de repente quando Fradique cita um problema de ordem pública, a construção de seu quiosque em Cintra, e aqui aproveita para deixar uma crítica ao seu país: "Três mil e oitocentos francos achatados em entulho. Tudo tende à ruína num país de ruínas [...] E é com estes elementos alegres [juristas] que nós procuramos restaurar o nosso império de África!” (Ibidem, págs. 143/4). O autor de Lapidárias parece soltar suas farpas sempre quando há a oportunidade para isso. Lembrando que na oportunidade da escrita Portugal não mais conseguia manter suas colônias na África, que era deliberadamente dividida à régua por outros países.

A terceira carta publicada tem como destinatário Oliveira Martins ${ }^{7}$, importante homem da

\footnotetext{
${ }^{7}$ Órfão de pai, teve uma adolescência difícil, não chegando a concluir o curso liceal, que o levaria à Escola Politécnica, para o curso de Engenheiro Militar. Esteve empregado no comércio, de 1858 a 1870, mas, nesse ano, devido à falência da empresa onde trabalhava, foi exercer funções de administrador de uma mina na Andaluzia. Quatro anos depois regressou a Portugal para dirigir a construção da via férrea do Porto à Póvoa de Varzim e a Vila Nova de Famalicão. Em 1880 foi eleito presidente da Sociedade de Geografia Comercial do Porto e, quatro anos depois, director do Museu Industrial e Comercial do Porto. Mais tarde desempenhou as funções de administrador da Régie dos Tabacos, da Companhia de Moçambique, e fez parte da comissão executiva da Exposição Industrial Portuguesa. Foi deputado em 1883, eleito por Viana do Castelo, e em 1889 pelo círculo do Porto. Em 1892 foi convidado para a pasta da Fazenda, no ministério que se organizou sob a presidência de Dias Ferreira, e em 1893 foi nomeado vice-presidente da Junta do Crédito Público. Elemento animador da Geração de 70, revelou uma elevada plasticidade às múltiplas correntes de ideias que atravessaram o seu século. Oliveira Martins colaborou nos principais jornais literários e científicos de
} 
história de Portugal no século XIX. Nela Fradique ironicamente disserta sobre a Eternidade, quando da descoberta da múmia de Ramsés. Mesmo sabendo do fato de que Eça e seus camaradas tenham criado um Fradique sem o propósito de continuidade (o que nos parece) é no mínimo irônico e em uma leitura pós-efabulações que esse homem discuta qualquer assunto que tenha relação com a Eternidade (o poeta marca com maiúscula). Um Fradique que fora mumificado, para que "os homens gozassem na sua forma terrena, segundo diz o Escriba, <<as vantagens da Eternidade $>>$ " (Ibidem, pág. 145).

Compara Ramsés aos “donos de homens”, grandes líderes da humanidade (Napoleão III, Bismark e um Czar russo). Ironiza a tacanhez dos semblantes destes grandes homens. Irônico também seria discutir (o que nos faz pensar na resposta de Martins) exatamente esse assunto com um homem de tanta importância política em Portugal. Parecem ambos ironizar o poder e suas consequências e relatividade.

$\mathrm{Na}$ conclusão de sua carta (e ele chama mesmo de conclusão), Fradique remonta a comparação destes grandes homens à figura de Ramsés para depois, a sua maneira, quebrar essa ligação:

As únicas fisionomias nobres são as das feras, genuínos Ramezes no seu deserto, que nada perderam na sua força, nem da sua liberdade. O homem moderno, esse, mesmo nas alturas sociais, é um pobre Adão achatado entre as duas páginas de um código. (Ibidem, pág. 149)

Partindo de um mote que pode inicialmente parecer ingênuo, Fradique monta uma relação bastante irônica com figuras da história da humanidade e também com personagens de sua época. Ramsés fora definitivamente o "dono de homens" porque reinava ao seu bel prazer, sem que sobre ele caíssem códigos e leis que determinassem ou até mesmo impedissem ações que provariam a sua onipotência. Logo, tais "donos de homens" modernos não são realmente "donos de homens", mas sim símbolos eleitos para fortificar algo em comum, até o momento em que esse "comum" não mais seja aceito. Torna-se, por fim, coerente essa conversa entre Fradique Mendes e Oliveira Martins, levando em consideração, como dito, a importância desta figura para a política portuguesa, também autor de livros sobre política, filosofia, antropologia e também ficção.

Na quarta carta publicada, e interessada a Madame S., o poeta disserta sobre a questão das

Portugal, assim como nos políticos e socialistas. A sua vasta obra começou com o romance Febo Moniz, publicado em 1867, e estende-se até à sua morte, em 1894. Na área das ciências sociais escreveu, por exemplo, Elementos de Antropologia, de 1880, Regime das Riquezas, de 1883, e Tábua de Cronologia, de 1884. Das obras históricas há a destacar História da Civilização Ibérica e História de Portugal, em 1879, O Brasil e as Colónias Portuguesas, de 1880, e Os Filhos de D. João I, de 1891. A sua obra suscitou sempre controvérsia e influenciou a vida política portuguesa, mas também historiadores, críticos e literatos do seu tempo e do século XX. É também necessário destacar a sua obra História da República Romana. Defendia a tese, no entanto, de que os povos formados a partir do negro e do índio eram incapazes para o progresso. (BOMFIM, Manuel. A América Latina: males de origem. Rio de Janeiro: Topbooks, 1993, p. 254) 
línguas estrangeiras. Em um determinado momento da epístola, compara a pronúncia correta das palavras em um idioma a um instrumento da lavoura:

Porque as línguas, minha boa amiga, são apenas instrumentos do saber - como instrumentos de lavoura [...] é fazer como o lavrador, que em vez de se contentar com [...] com um ferro simples, se aplicasse [...] a embutir emblemas no ferro e esculpir flores e folhagens ao comprido do pau. (Ibidem, pág. 151)

Para um viajante como Fradique Mendes, para um homem do mundo, e também para aquele que enquanto está inserido em uma cultura faz radicalmente parte dela, pode parecer de suma importância que a língua seja pronunciada tão "genuína e puramente que pareça que nasceu dentro de cada uma delas, e que por meio de cada uma delas se pediu o primeiro pão e água da vida" (Ibidem, pág. 151). Engana-se quem o afirma.

Nas cartas publicadas há sempre alguns trechos em inglês ou francês, até mesmo na parte biográfica de Fradique Mendes. Nesses trechos não há preocupação alguma com traduções (a não ser as cartas a Madame de Jouarre, que foram totalmente traduzidas - Há até a indicação disso como nota de rodapé). De fato os interlocutores dessas correspondências são conhecedores de pelo menos duas das línguas mais importantes do ocidente, como dito, o inglês e o francês. E mesmo Fradique sendo um viajante e "temporariamente nativo" das partes e culturas mais singulares do planeta, acredita que o homem só deve falar "impecável, segura e puramente" o seu idioma materno. "[...] todas as outras a deve falar mal, orgulhosamente mal, com aquele acento chato e falso que denuncia logo o estrangeiro." (Ibidem, 151).

Aqui fala o português excêntrico e principalmente com lapsos de nacionalidade. "Na língua verdadeiramente reside a nacionalidade; - e quem for possuindo com crescente perfeição os idiomas da Europa, vai gradualmente sofrendo uma desnacionalização.” (Ibidem, pág. 151).

Pergunta-se se Fradique, em determinadas situações falaria o inglês, ou o francês sem nenhum sotaque, ou em outras se se sentiria orgulhoso de somente afrancesar seu magnífico português. Se na escrita realista houvesse o que na moderna foi ato de carnavalização da língua escrever exatamente como se fala - talvez assim poderíamos apontar que Fradique seria um orgulhos português ou um homem desnacionalizado - no que se refere à língua. Acreditamos que o poeta Fradique Mendes tem excentricidade e personalidade o suficientes para ser ora um, ora outro. O que bem entender. Até porque Fradique é um "ser que rola através das nacionalidades alheias, sucessivamente se disfarça nelas” (Ibidem, pág. 153)

Afirma ironicamente que "o perfeito poliglotismo é um instrumento de alta escroquerie" (fraude). Fradique inclina-se na opinião de que se torna pieguice e subserviência pronunciar os vocábulos estrangeiros de maneira a ser um francês, ou um inglês, ou um russo etc. 
Além disso o propósito de pronunciar com perfeição línguas estrangeiras constitui uma lamentável sabujice para com o estrangeiro. Há aí, diante dele, como o desejo servil de não sermos nós mesmos, de nos fundirmos nele, no que ele tem de mais seu, de mais próprio, o Vocábulo. (Ibidem, pág. 153)

É de fato curioso lembrarmos aqui o episódio citado pelo narrador da biografia de Fradique, episódio que mostra o lado oposto do que Fradique afirma. Quando da pronúncia equivocada do garçom africano que ao chamar o poeta de "le deux", pronuncia com o acento característico de sua pátria e o narrador entende que o africano se refere a Fradique como "le dieu". Portanto na biografia um episódio que marca as consequências da má pronuncia, e na carta de Fradique (um "dieu" para o narrador) um valioso documento a favor da má pronúncia, para não se perder o acento majestoso da língua mãe, e com isso a nacionalidade. Em contra posição Fradique apresenta, também ironicamente, uma situação em que uma pessoa poderia, sem desconforto algum, viajar toda a Europa sem sequer saber bem seu próprio idioma:

Eu tive uma admirável tia que falava unicamente o português (ou antes o minhoto) e que percorreu toda a Europa com desafogo e conforto. [...] Esta senhora [...] comia simplesmente ovos. [...] Para ela huevos, aeufs, eggs, das, ei, eram sons da Natureza bruta, pouco diferentes do coaxar das rãs, ou de um estalar de madeira. [...] Esta expedita senhora reclamava o famulo do Hotel, cravava nele os olhos agudos e bem explicados, agachava-se gravemente sobre o tapete, imitava com o rebolar lento das saias tufadas uma galinha no choco, e gritava ki ki ki! Ko ko ki ki! Ko ko ko ko! (Ibidem, pág. 154/5)

Fradique termina a carta a Madame de S. dando a sugestão para que ela não se importe com a pronúncia correta de um idioma. Diz que Raul (rapaz que aprenderia a pronúncia perfeita do espanhol) deve aprender a tocar guitarra, o que seria de maior serventia e lirismo.

Convém mais na mocidade, e mesmo na velhice, saber, por meio das quatro cordas de uma viola, desafogar a alma das coisas confusas e sem nome que nela tumultuam, do que poder, através das estalagens do mundo, declamar com perfeição e pão e o queijo - em sueco, holandês, grego, búlgaro, e polaco. (Ibidem, pág. 154)

A quinta carta publicada tem como destinatário Guerra Junqueiro ${ }^{8}$, político e poeta, "A sua carta transborda de ilusão poética” (Ibidem, pág.155). Inicia o documento discutindo a posição de

\footnotetext{
${ }^{8}$ Abílio Manuel Guerra Junqueiro (Freixo de Espada à Cinta, 17 de Setembro de 1850 — Lisboa, 7 de Julho de 1923) foi bacharel formado em direito pela Universidade de Coimbra, alto funcionário administrativo, político, deputado, jornalista, escritor e poeta. Foi o poeta mais popular da sua época e o mais típico representante da chamada "Escola Nova". Poeta panfletário, a sua poesia ajudou criar o ambiente revolucionário que conduziu à implantação da República.
} 
Guerra Junqueiro em relação aos rituais religiosos, à liturgia. Reforça, com um olhar de antropólogo, que as liturgias servem para que cada povo possa tomar contato com seus deuses e assim pedir favores. Apresenta, com conhecimento de causa, cenas da vida ritualística de "padres" em Septa-Sindhou, "no país das Sete Águas, no Vale Feliz, na terra dos Aryas" (Ibidem, pág. 156).

$\mathrm{O}$ autor da carta tenta mostrar ao amigo que as religiões em toda e qualquer parte do planeta apresentam, se não o mesmo ritual, as mesmas propostas. "Trata-se pois simplesmente de convencer Indra a que, sempre propício, derrame sobre Septa-Sindhou todos os favores que podem apetecer um povo rural e pastoral” (Ibidem, pág. 157).

Um olhar crítico sobre uma cultura ocidental é apresentada neste trecho. Não há, pelo que nos parece, um momento empírico, como acontece em Agualusa. Há um distanciamento dessa experiência. Ou melhor, há não a participação, mas a observação. Fradique, como profundo conhecedor e viajante (aqui talvez aquele que Walter Benjamin trabalha em $O$ Narrador), traz uma ampla visão comparativa sobre as religiões, dissertando ao amigo algo de que seria a essência de todas elas. O ponto em comum. “[...] as Religiões, amigo meu, consistiram sempre praticamente num conjunto de práticas, pelas quais o homem simples procura alcançar da amizade de Deus os bens supremos da saúde, da força, da paz, da riqueza. (Ibidem, pág. 158).

Fradique, nesta carta transita entre culturas e entre uma linha temporal universal com certa facilidade. Fala sobre as diferenças culturais e, como um deus observador, volta e adianta-se no tempo para explicar um pouco ao amigo sobre a história das religiões. Com agilidade vai do presente ocidente à antiguidade clássica, provando que a liturgia, como hoje, devia ser respeitada: "[um antigo] responderá que a Religião consiste em paces doerum quarere, em apaziguar os Deuses. [...] $\mathrm{Na}$ ideia do antigo isso significa cumprir os ritos, as práticas, as fórmulas [...]" (Ibidem, pág. 159).

O que nos é aqui significativo não é exatamente a discussão sobre ritos ou liturgia, o que nos chama verdadeiramente a atenção é a facilidade com que este homem tem de dissertar (poder persuasivo da palavra) sobre assuntos que vão além de "seu lugar" (aqui não podemos falar Portugal, mas sim Europa). Somente um homem com o conhecimento de Fradique Mendes (prático também, depois) pode, com tanta destreza, explicar sobre qualquer assunto, principalmente os que geram, o que é típico fradiquiano, tanta discussão e controvérsia.

Fradique parece tratar esse delicado tema com parcimônia. O satirizador aqui nos parece ser o interlocutor (destinatário), que como resposta recebe do poeta uma carta de lição ao respeito da liturgia, em contra posição à Moral e a Teologia (que Fradique ataca, instâncias que tentam, segundo o poeta, se sobrepor a essência da prática religiosa comum). Em determinado momento do documento, ainda com uma lição de teologia ao amigo, Fradique apresenta pontos em comum dentre duas religiões aparentemente distintas, o catolicismo e o budismo. Fradique parece conhecer 
profundamente a ambas, é de fato católico, budista, antigo crente dos deuses do Olimpo e tudo mais o que lhe for aprazível como estudo do método religioso.

O "antropólogo" Fradique Mendes, com um olhar amplo e crítico, empírico e ao mesmo tempo distanciado (com um pesquisador primeiramente parece tomar pra si o objeto - como trabalhado na parte biográfica pelo narrador) depois propositalmente parece de distanciar do objeto para analisá-lo fria e amplamente:

Uma religião, quando mais se materializa, mais se populariza - e portanto mais de diviniza. Não se espante! Quero dizer, que quanto mais se desembaraça dos seus elementos intelectuais de Teologia, de Moral, de Humanitarismo, etc., repelindo-os para as suas regiões naturais que são a Filosofia, a Ética e a Poesia, tanto mais coloca o povo face a face com o seu Deus, numa união direta e simples, tão fácil de realizar que, por um mero dobrar de joelhos, um mero balbuciar de Padre-nossos, o homem absoluto que está no céu vem ao encontro do homem transitório que está na terra. (Ibidem, pág. 164)

Um pesquisador que se utiliza como tática de convencimento o contra argumento. Há trechos em que Fradique se utiliza da possível fala, ou resposta (que aqui não temos) de seu interlocutor para, logo depois, jogar um argumento contrário e irrebatível. Como um sermão de Veira (o que nos é mais próximo), utiliza-se talvez da própria retórica litúrgica do sermão para convencer o amigo.

<<Você porém dirá (e de fato diz): Tornemos essa comunicação puramente espiritual, e que, despida de toda e exterioridade litúrgica, ela seja apenas como o espírito humano falando ao espírito divino〉>. Mas para isso é necessário que venha o Milênio - em que cada cavador de enxada seja um filósofo, um pensador [...]. (Ibidem, pág. 164)

Ainda como argumentação para defender seu ponto de vista, e para nós algo também tipicamente fradiquiano, é este explanar sobre o que diria um inglês, um africano, um hindu, um minhoto, porque, afinal, Fradique os conhece empírica e teoricamente:

O inglês dirá: - <<É ir ao serviço ao domingo, bem vestido, cantar hinos $>$. O hindu dirá: - <<É fazer poopak todos os dias e dar o tributo ao Mahadeo >>. O africano dirá: - <<É oferecer só Mulungu a sua ração de farinha e óleo »>. O minhoto dirá: - <<É ouvir missa, rezar as contas, jejuar à sexta-feira, comungas pela Páscoa〉>. E todos têm razão, grandemente! (Ibidem, pág. 165)

No final de sua carta a Guerra Junqueiro, Fradique disserta rapidamente sobre um exemplo que ele mesmo presenciou em Zambeze (região sudeste da África), e que aqui longamente vemos a necessidade de citar, que mostra como é possível ter contato com um Deus de maneira não litúrgica, o que aproximaria esse "crente" de seres citados na carta, como Sócrates e Sêneca, 
filósofos que tornariam pura a comunicação espiritual, sem as exterioridades práticas. A seu modo, implicando um tom de piada, o que nos faria até mesmo duvidar dessa experiência de Fradique, este relata o acontecido:

Um presenciei eu, deliciosamente puro e intimo. Foi nas margens do Zambeze. Um chefe negro, por nome Lubenga, queria, nas vesperas de entrar em guerra com um chefe visinho, communicar com o seu Deus, com o seu Mulungú (que era, como sempre, um seu avô divinisado). O recado ou pedido, porém, que desejava mandar á sua Divindade, não se podia transmittir através dos Feiticeiros e do seu ceremonial, tão graves e confidenciaes matérias continha... Que faz Lubenga? Grita por um escravo: dá-lhe o recado, pausadamente, lentamente, ao ouvido: verifica bem que o escravo tudo comprehendera, tudo retivera: e immediatamente arrebata um machado, decepa a cabeça do escravo, e brada tranquillamente- «parte!» A alma do escravo lá foi, como uma carta lacrada e sellada, direita para o céo, ao Mulungú. Mas d'ahi a instantes o chefe bate uma palmada afflicta na testa, chama á pressa outro escravo, diz-lhe ao ouvido rapidas palavras, agarra o machado, separa-lhe a cabeça, e berra:- «Vai!»

Esquecera-lhe algum detalhe no seu pedido ao Mulungú... O segundo escravo era um post-scriptum...

Esta maneira simples de communicar com Deus deve regosijar o seu coração. Amigo do dito-Fradique. (Ibidem, pág. 166/7)

De fato tal experiência faria com que Guerra Junqueiro se regozijasse, mas também podeira

fazê-lo se irritar, já que tal situação faria também com que ele intendesse que sua opinião estaria sendo levada ao nível do risível. O tom piadista da situação (principalmente no post-scripitum) acaba por fortalecer o argumento do remetente da carta, já que só em ficção (piada) é que a opinião de Guerra Junqueiro poderia ser vista na prática.

A sexta carta publicada é endereçada à Ramalho Ortigão ${ }^{9}$, grande amigo e camarada literato

\footnotetext{
${ }^{9}$ José Duarte Ramalho Ortigão (Porto, 24 de Outubro de 1836 — Lisboa, 27 de Setembro de 1915) foi um escritor português. No Porto, envolveu-se na Questão Coimbrã com o folheto "Literatura de hoje", acabando por enfrentar Antero de Quental num duelo de espadas, a quem apodou de cobarde por ter insultado o velho António Feliciano de Castilho. Ramalho ficou fisicamente ferido no duelo travado, em 6 de Fevereiro de 1866, no Jardim de Arca d'Água. [...] Reencontra em Lisboa o seu ex-aluno Eça de Queirós e com ele escreve um "romance execrável" (classificação dos autores no prefácio de 1884): O mistério da estrada de Sintra (1870). No mesmo ano, Ramalho Ortigão publica ainda Histórias cor-de-rosa e inicia a publicação de Correio de Hoje (1870-71). Em parceria com Eça de Queirós, surgem em 1871 os primeiros folhetos de As Farpas, de que vem a resultar a compilação em dois volumes sob o título Uma Campanha Alegre. Em finais de 1872, o seu amigo Eça de Queirós parte para Havana exercer o seu primeiro cargo consular no estrangeiro, continuando Ramalho Ortigão a redigir sozinho As Farpas. Ramalho Ortigão tornara-se uma das principais figuras da chamada Geração de 70. Vai acontecer com ele o que aconteceu com quase todos os membros dessa geração. Numa primeira fase, pretendiam aproximar Portugal das sociedades modernas europeias, cosmopolitas e anticlericais. Desiludidos com as Luzes europeias do progresso material, porém, numa segunda fase voltaram-se para as raízes de Portugal e para o programa de um "reaportuguesamento de Portugal". É dessa segunda fase a constituição do grupo "Os Vencidos da Vida", do qual fizeram parte, além de Ramalho Ortigão, o Conde de Sabugosa, o Conde de Ficalho, Marquês de Soveral, Conde de Arnoso, Antero de Quental, Oliveira Martins, Guerra Junqueiro, Carlos Lobo de Ávila, Carlos de Lima Mayer e António Cândido. À intelectualidade proeminente da época juntava-se agora a nobreza, num último esforço para restaurar o prestígio da Monarquia, tendo o Rei D. Carlos I sido significativamente eleito por unanimidade "confrade suplente do grupo". Na sequência do assassínio do Rei, em 1908, escreve D. Carlos o Martirizado. Com a implantação da República, em 1910, pede imediatamente a Teófilo Braga a demissão do cargo de bibliotecário da Real Biblioteca da Ajuda, escrevendo-lhe que se recusava a aderir à República "engrossando assim o abjecto número de percevejos que de um buraco estou vendo nojosamente cobrir o leito da governação". Saiu em seguida para um exílio voluntário em Paris, onde vai começar a escrever as Últimas Farpas
} 
de Eça de Queiroz (possível narrador da biografia de Carlos), segundo Frederico de Sá Perry Vidal, também inspiração na criação de Fradique: "Para uns, o famoso diletante quereria ser a síntese ideal de uma geração; e por isso o criou Eça com traços colhidos ora em si próprio, ora em Ramalho Ortigão, ora em Antero, em quase todos os seus mais altos camaradas de espírito” (VIDAL, 1950. pág. 7)

Escrever uma carta para Ramalho Ortgião, a nosso ver, é estabelecer uma conversa sobre a própria proposta de criação de Fradique Mendes, é discutir, entre amigos (que é exatamente o conteúdo da carta) os olhares e as perspectivas daqueles camaradas da geração de 70, de que faziam parte Ramalho, Eça, Guerra, Antero, entre outros. A carta inicia com a narrativa de Fradique na ocasião em que esperava a chegada de Ramalho, como típico flaneur, encontra amigos como Eduardo Prado e conhece o sr. Mendibal. Os três aguardam ansiosamente por Ramalho em um boulevard. Aquele que parecia coadjuvante se torna o centro das atenções na carta dirigida ao amigo Ramalho Ortigão. sr. Mendibal conta sobre sua relação com uma francesa, e de todas os requintes e benfeitorias dessa mulher. "Eu não sei se o senhor [Fradique] é casado. [...] Mas se não é, sempre lhe direi, como digo a todo mundo: - Case com uma francesa!...” (Ibidem, pág. 171).

Após a constatação da ausência de Ramalho, os homens se separam, Fradique flana um pouco e encontra outro camarada - Chambray. Este começa a lhe contar sobre o encontro com "una grande et belle femme [...] com um jeito guloso de molhar os beiços", com a qual compartilhou espaço no comboio. E esta relação relâmpago entre Chambray e essa mulher é narrada a moda romanesca, ao mesmo tempo lirica e eroticamente. E no final do discurso de Chambray (após falar sobre o mesmo ramo de cravos amarelos que sr. Mendibal deu para sua esposa francesa) o leitor percebe que Fradique está falando da mesmo mulher. A francesa casada com Mendibal que se engraçou com Chambray.

O que nos parecem ser duas histórias de amor se transformam, ironicamente, e com a linguagem fradiquiana isso se potencializa ainda mais - "Eu digo que, em resumo, este nosso Mundo é perfeito e não há nos espaços outro mais bem organizado" (Ibidem, pág. 174/5) - Finaliza em uma discussão com seu amigo de produção literária sobre uma das propostas da escola cujas características ambos compactuam. Trata-se de um documento transvestido de história romântica para que dois escritores possam colocar em xeque a questão do adultério, tema corriqueiro entre os escritores realistas da segunda do XIX.

Podemos até mesmo afirmar que há aqui uma carta com uma proposta metalinguística, pois

(1911-1914) contra o regime republicano. O conjunto de As Farpas, mais tarde reunidas em quinze volumes, a que há que acrescentar os dois volumes das Farpas Esquecidas, e o referido volume das Últimas Farpas, foi a obra que mais o notabilizou por estar escrita num português muito rico, com intuitos pedagógicos, sempre muito crítico e revelando fina capacidade de observação. Eça de Queirós escreveu que Ramalho Ortigão, em As Farpas, "estudou e pintou o seu país na alma e no corpo". (Novas Cartas inéditas de Eça de Queirós, Camilo, etc., a Ramalho Ortigão, Rio de Janeiro, Alba Editora, 1940, p. 95; Leão Ramos Ascensão, O Integralismo Lusitano, Edições Gama, Porto, 1943, p. 49) 
por meio de uma linguagem irônica típica do realismo queirosiano, este e outros, retornam à própria proposta de produção de seus textos, o discurso da crítica aos costumes e aos hábitos que, segundo eles, infectam a humanidade. E Fradique vai além, com um olhar feroz e analítico, faz perceber que esses problemas sociais na verdade habitam porque são necessários, e são eles que, de certa maneira, organizam uma relação social. Para Fradique uma questão ética e moral é muitas vezes relativa. Ao mostrar esse triângulo amoroso, Fradique demonstra que mesmo após atos imorais e antiéticos, os envolvidos vão colher diretamente bons frutos.

Talvez aqui tenhamos um princípio maquiavélico de que os fins justificam os meios, por mais que esses meios, no âmbito social, sejam muitas vezes invisíveis e incontroláveis; diríamos que instintivos. Um mal original que resultará no bem comum, e com o universo conspirando para o equilíbrio:

[...] obtiveram um ganho positivo na vida. Chambray passou por um imenso prazer e uma imensa vaidade - os dois únicos resultados que ele conta na existência como proventos sólidos, e valendo o trabalho de existir. Madame experimentou uma sensação nova ou diferente, que a desenervou, a desafogou, lhe permitiu reentrar mais acalmada na monotonia do seu lar, e ser útil aos seu com rediviva aplicação. E o Argentino adquiriu outra inesperada e triunfal certeza de quanto era amado e feliz na sua escolha. Três ditosos, ao fim desse dia de primavera e de campo. E se daqui resultar um filho (o filho que o Argentino apetece), que herde as qualidades fortes e brilhantemente gaulesas da Chambray, acresce, ao contentamento individual dos três, um lucro efetivo para a sociedade. Este mundo portanto está superiormente organizado. (Ibidem, pág. 175)

A sétima carta publicada dirige-se novamente à Madame de Jouarre. É escrita de Lisboa, o que de fato marca o propósito da carta, a discussão do que se torna para o remente a sua cidade. "Juramento bem estouvado, este, de lhe mandar todas as semanas, pelo correio, Portugal em $<<$ descrições, notas, reflexões e panoramas $>>$ " (Ibidem, pág. 176).

No início Fradique menciona pertencer à Portugal, ou melhor, diz que Portugal lhe pertence. Ainda diz que sua terra "está a la disposicion de usted...". Ironicamente esta terra pertence a um português que convida uma francesa, em espanhol, a conhecer aquilo que chama de pátria mãe.

De fato se torna impossível aqui não buscar relação com a carta também endereçada à sua madrinha e confidente, em que ambos discutem (claro que subentendendo a resposta de sua interlocutora) a questão das línguas estrangeiras e suas pronúncias. "Na língua verdadeiramente reside a nacionalidade”. Porque então não dizer que Portugal está à disposição da madrinha em bom e velho português?

Aqui talvez haja uma questão bastante complexa sobre a identidade portuguesa. O país guardando suas devidas proporções durante dos séculos das descobertas marítimas - sempre se posicionou na periferia econômica e cultural europeia. Há uma proximidade geográfica com a 
Espanha e isso faz com que culturalmente também haja uma aproximação, se não um apagamento do mais "fraco".

Boaventura de Sousa Santos levanta a teoria do jeremíada nacional ${ }^{10}$, e discute sobre duas das patologias desse princípio levantado, colocando, o que nos interessa aqui, algumas teorias de pensadores do século XIX:

[...] o iberismo e nacionalismo. [...] Se o nacionalismo tem sido ora "tradicionalista" (quase sempre) ora "racionalista" (a geração de 70), o iberismo (unitarista ou federalista; político ou cultural) tem sido, ora a "internacional cristã" (Sardinha), ora republicano e socializante (Antero e Oliveira Martins). Daí que, sendo polos do mesmo tipo de discurso, haja entre eles uma grande cumplicidade e tenham mesmo sido frequentemente combinados no pensamento do mesmo autor. Por um lado, o espantalho iberista tem feito muitas vezes dançar o espantalho nacionalista. No século XIX, a exaltação iberista corre de par com o culto do 1. de Dezembro (Catroga, 1985: 437). Por outro lado, o iberismo surge muitas vezes como forma de nacionalismo alargado (Antero, Oliveira Martins, Natália Correia). Na segunda metade do século XIX, os federalistas ibéricos apresentavam-se como nacionalistas defensores de uma posição que permitiria a Portugal recuperar o prestígio internacional, libertando-se do protetorado inglês (M. Mascarenhas, 1980: 18). Sinibaldo Mas propunha para a capital da Ibéria, Santarém, a salvo da influência francesa e da esquerda inglesa (Catroga, 1985: 428). ( SANTOS. 2008, pág. 71)

Fradique Mendes pode estar fazendo com que o espantalho do nacionalismo dance frente o espantalho do iberismo. Um nacionalismo alargado, ou até mesmo uma tentativa de idealizar um Portugal republicano e socializante. Mas acaba por conduzir Madame de Jouarre por uma Lisboa de "densa treva", de "luzinhas remotas e vagas", onde Fradique parece refletir o que é "descobrir no universal mistério do Ser" naquilo que simboliza Lisboa e seu povo, e por extensão, um encontro com seu íntimo.

Se encontrar com seu próprio lugar, ou escapar dele, é de fato questão que permeia todo o processo de construção dessa personagem, não só em Eça, mas também em boa parte dos efabuladores. Com José Eduardo Agualusa, Fradique parece se perder em terra desconhecida e mágica, mas ao mesmo tempo em que se perde, acha-se em sua individualidade como português, por isso há em suas críticas, como veremos, sempre a comparação das essências portuguesa e angolana. Com Fernando Venâncio há uma proposta de reaproximação dessa figura, como se ele tivesse feito as pazes com sua terra e principalmente como tudo aquilo que ela representaria após a Revolução dos Cravos (visto no capítulo referente à obra), também na nova figura fradiquiana criada pelo autor, de herói nacional (espião a serviço da coroa). Há, na realidade, um movimento pendular na teia fradiquiana das efabulações, no que se refere ao "achar-se" e ao "perder-se"

\footnotetext{
${ }^{10}$ É um discurso de decadência e de descrença e quando projeta uma ideia positiva do país fá-lo de modo elitista e desfocado e por isso será sempre à beira da frustração, da queda e do ressentimento. (SANTOS. 2008, pág. 71)
} 
identitariamente.

A cena que é apresentada a Madame de Jouarre é claramente de melancolia, de tristeza e principalmente de tédio, de não satisfação, de não movimento, alguns diriam que "tipicamente portuguesa”. E além disso um Fradique que ao mesmo tempo que se identifica com tudo isso, não se conforma com tal tratamento.

A imagem de Carlos aqui é contrária da passada pela chegada em Lisboa. Podemos dizer que o poeta é a metáfora do cosmopolitismo, do movimento, da rapidez, da modernidade, de Paris e Londres; Já Lisboa, e Portugal de maneira geral, vêm na contra mão.

Lisboa representa o "aguardo", a "espera”, por isso tão mítico, diferente de Fradique, que é o agora, o instantâneo. Lisboa é o "exótico", o "desejo":

Como é que Portugal, sendo um dos países menos desenvolvidos da Europa, é capaz de tanta utopia (do sebastianismo à revolução de 25 de Abril de 1974), a tal ponto que seria certamente uma grande potência numa "Europa dos desejos" (1987). Muito antes dele, há pouco mais de cem anos, Antero que Quental exclamava num tom ainda mais pessimista: "Nunca povo algum absorveu tantos tesouros, ficando ao mesmo tempo tão pobre" (1982: 264). (SANTOS. 2008, pág. 53)

E ainda afirma o autor de Esquemas de Fradique, em entrevista e quando perguntado se haveria algo em comum entre a criação de Fradique Mendes com alguns ideários portugueses, como o sebastianismo e as grandes navegações:

Digamos que as descobertas portuguesas já foram acompanhadas de narrativas. O sebastianismo é também uma narrativa ideológica, que os portugueses dos séculos XVI e XVII contam a si próprios pra se aguentarem nas adversidades, e no fundo pra não se frustrarem, pra conservarem até um pouco de positividade de sua autoimagem. "Nós estamos em uma situação tremenda, sem nobreza, sem dinheiro, sem rei, mas Sebastião vai voltar". O Fradique é também uma narrativa ideológica. Digamos que há uma mensagem subliminar do Eça que é: "Nós, portugueses, somos uma desgraça, péssimos numa porção de coisas. Mas imaginemos que nós éramos um Fradique". Fradique recolhe, portanto, tudo aquilo que os portugueses deveriam ser, deveriam poder ser e não são. (Contra Ponto. Revista da PUCMINAS http://periodicos.pucminas.br/index.php/contraponto/article/view/2234/pdf 1 Visitado em 16/07/2012)

Venâncio encontra um paralelo entre Fradique e alguns elementos do ideário lusitano, por se tratarem de narrativas ideológicas, mas de fato Fradique vai na contra mão de tudo isso por representar a ação e o desenvolvimento, não somente o "vangloriar-se pelo passado" ou o "aguardar o ser mítico salvar o futuro". É o estático versus o movimento.

Eça e seus camaradas da geração de 70 certamente tinham a consciência disso. E é essa 
briga que vemos nesta carta a Madame de Jouarre, um cosmopolita, que por mais que tenha sido produto também de Portugal, se vê indignado, "patriota descontente" (pág. 180) frente o marasmo e a quietude lusitanos. "Espera amarga, espera estéril” (pág. 181).

Fradique conta sua narrativa e nela nos parece imprescindível a presença de uma personagem estrangeira, o criado Smith (escocês). São os olhos do estrangeiro frente o atraso e o descompasso civilizatório:

\footnotetext{
"Eu não chorei - mas tinha vergonha, uma imensa e pungente vergonha do Smith! Que pensaria aquele escocês da minha pátria - e de mim, seu amo, parcela dessa pátria desorganizada? Nada mais frágil que a reputação das nações, Uma simples tipoia que falta de noite, e eis, no espírito do Estrangeiro, desacreditada toda uma civilização secular!” (QUEIROZ. 1923., pág. 182).
}

Por fim o discurso da carta é remontado quando há o reconhecimento de Fradique com o seu lugar e com o seu povo: "Aquele bandido conhecia o sr. D. Fradique. Tinha um sorriso brejeiro e serviçal. Ambos eramos portugueses. Dei uma libra àquele bandido" (Ibidem, pág. 185).

A critica à pátria é feita, com a ironia típica de uma Fradique (ou de um Eça). Os problemas sociais são mostrados. A reflexão do remetente é certamente provocada, mas esse Fradique Mendes vezes se reconhece dentro do caos, dentro da desordem, dentro da sua periferia.

A oitava carta tem como destinatário o Sr. E. Mollinet, diretor da Revista de Biografia e de História. Ela consiste na promoção da figura de José Joaquim Alves Pacheco, "Pacheco era entre nós superior e ilustre porque tinha um imenso talento" (Ibidem, pág. 186). Assim como o próprio autor da carta (excetuando-se as Lapidárias), Pacheco não havia deixado documento que exteriorizasse este talento de que fala Fradique. Pacheco fora Deputado, Diretor geral, Ministro, Governador de bancos, Conselheiro de Estado, Presidente do conselho. "Pacheco tudo foi, tudo teve, neste país que, de longe e a seus pés, o contemplava, assombrado do seu imenso talento." (Ibidem, pág. 186).

O remetente parece criar durante grande parte do documento uma expectativa: qual é, ou foi, o grande talento de Pacheco? Era este, que nascera em Coimbra, em uma aula de direito natural: “<<o século XIX era um século de progresso e de luz $>>$ " (Ibidem, pág. 187). A todo momento "pensabundo" refletia sobre o progresso e as luzes do século XIX. Na caracterização de Pacheco, Fradique evidencia metaforicamente o "olhar ao progresso e às luzes". A todo momento esta personagem de talento se apresenta com os "óculos dourados", ou com os "óculos a faiscar", também "A testa de Pacheco oferecia uma superfície escanteada, larga e lustrosa". Uma personagem que por balbuciar máximas do progresso fora ovacionado por um povo e por partidos políticos. Burburinhos que geravam a todo momento uma expectativa de palavra, de ação. Até que bastava sua presença (sem palavra) e todos se contentavam. 
Sem dúvida esta é uma das mais fortes representações daquilo que falamos sobre a estagnação da realidade, a espera por aquilo que poderá definitivamente "salvar" e definir aquilo que seria a essência do que é ser português, do que poderia representar isso. Pacheco tornou-se, como se diz popularmente, uma "lenda" para o povo e a política lusitanas, há a tentativa de se criar um mito. Há em Pacheco a representação da utopia, nada em empirismo ou efetivamente ação (o que representa a não exteriorização daquilo que pensava em palavra escrita). O imaginário português está em Pacheco: o homem das luzes, aquele que universalmente representaria um país de descobertas. Sobre o assunto disserta Eduardo Lourenço: "Mais quixotescos que D. Quixote, os portugueses não dão realmente muita atenção à realidade empírica. Suportam-na, mas não se dobram diante de nenhum desmentido da realidade" (LOURENÇO. 1999: 14)

Pacheco é a personagem do "não", embora tenha ocupado cargos importantes em Portugal, sempre há nele a expressão da reclusão e da "não ação". "Pacheco pertenceu logo às principais comissões parlamentares. Nunca porém acedeu a relatar um projeto" (QUEIROZ. 1946: 189). O silêncio é uma das suas principais características: "Apenas às vezes, em silêncio, tomava uma nota lenta" (Ibidem, pág. 189). E esta nota nunca fora à público. Logo aquilo que Pacheco realmente pensava não é de conhecimento público, conjecturáva-se, imaginava-se, especulava-se. Sempre que se expressava era para dissertar sobre máximas e clichês do progresso.

A criação desta imagem representativa de Pacheco, que resolveria a ânsia lusitana por sucesso é bem metaforizada quando Fradique relata a promoção do "grande talento" a Ministro da Marinha - que já é de fato elevar este homem a uma categoria de representação, para uma nação de descobertas marítimas:

Na sua pasta Pacheco não fez durante os longos meses de gerência <<absolutamente nada>>, como insinuaram três ou quatro espíritos amargos e estreitamente positivos. Mas pela primeira vez, dentro deste regime, a nação deixou de curtir inquietações e dúvidas sobre o nosso Império Colonial. Por quê? Porque sentia que finalmente os interesses supremos deste Império estavam confiados a um imenso talento, ao talento imenso de Pacheco. (Ibidem, pág. 190).

Como uma nação se sente bem representada por um político que nada faz em sua pasta de ministério, principalmente no tocante ao mais importante deles? Pois criou-se uma imagem mítica de Pacheco, e isso, mesmo não tendo referência à realidade empírica (como diz Lourenço), basta para que somente essa imagem, essa perspectiva, essa projeção, esse aguardo possa tranquilamente (apaticamente) representá-los. Aqui se fundamenta a crítica fradiquiana, que cheia de ironias constrói seus argumentos: um povo deve pedir ação, principalmente quando da boca de seus representantes há um discurso real de progresso. Mas em Portugal parece tudo ser singular.

Fradique relata um outro momento oportuno para analisarmos. Quando uma das poucas 
pessoas no Reino ousa colocar-se contra Pacheco recebe dele as seguintes palavras: "Ao ilustre deputado que me censura só tenho a dizer que enquanto, s. ex. aí nessas bancadas, faz berreiro, eu, aqui nesta cadeira, faço luz!” (Ibidem, pág. 191). Afinal, que luzes são estas? Além de uma escuridão proporcionada pela estagnação de um Estado atrasado e periférico, que tem somente sombras de palavras e mitos para se representar: "Em Pacheco pouco a pouco se concentrava a nação" (Ibidem, pág. 192).

O mito Pacheco parece se concretizar quando este começa a ganhar status de representação religiosa: "[...] a admiração pelo seu imenso talento chegou a tomar no país certas formas de expressão só próprias da religião e do amor". Pacheco é divinizado, e isso em um país extremamente católico é de fato o ponto mais alto que se pode chegar. Pacheco assemelha-se a Portugal: ambos carregam uma pseudo-imagem de si mesmos. Boaventura disserta: " $O$ desconhecimento de Portugal é, antes de mais, um auto-desconhecimento [psudo-imagem]. O Encoberto é a imagem da ignorância de nós mesmos refletida num espelho complacente" (SANTOS. 2008. pág. 54).

Ironicamente Fradique coloca frente a frente as imagens de Pacheco e de Portugal: Pacheco e Portugal, de resto, necessitavam insubstituivelmente um do outro. Sem Portugal - Pacheco não teria sido o que foi entre os homens: mas sem Pacheco - Portugal não seria o que é entre as nações! (QUEIROZ. 1923, pág. 188)

De fato, Portugal não é aquilo que acha que é, e Pacheco não é aquilo que os portugueses acham que ele é! - E o tom feroz de Fradique pode nos dizer que ambos se completam e se merecem, já que estão satisfeitos com tal posição, por mais que essa leitura de "posição" seja ambígua.

Por fim, a carta é finalizada quando Fradique encontra a viúva de Pacheco e ela, em desacordo, afirma a desgraça que o marido fora como homem. O que nos parece ser a única a levantar a bandeira, pós-morte do "grande talento", de que Pacheco fora um homem sem palavra, sem atitude, sem luzes! A voz da verdade aqui é feminina.

A nona carta publicada por "Eça" tem como endereço as mãos de Clara, "amiga" com a qual Fradique trocava juras de amor. Para ele a "rainha da graça entre as mulheres" (Ibidem, pág. 195). Neste documento Fradique parece remontar à sua amada suas sensações no momento de sua primeira visão frente tão graciosa mulher. Tenta passar para a interlocutora a imagem de um homem que "perdeu o chão". Pinta essa mulher com tintas divinas: "descobrisse a Obra sublime de um Mestre perfeito" (Ibidem, pág. 195).

Com o poder da retórica, com um nível de persuasão invejável Fradique Mendes, como conquistador, enlaça sua interlocutora nas malhas das sensações e dos desejos. “[...] e fui como um monge na sua cela, alheio às coisas mais reais, de joelhos e hirto no seu sonho, que é para ele a 
única realidade" (Ibidem, pág. 196). Como um típico poeta romântico Fradique se coloca em um nível abaixo de seu objeto de desejo: "E tem sido em mim agora um arquejante esforço para subir a uma perfeição idêntica àquela que em si tão submissamente adoro" (Ibidem, pág. 198). Parece enlaçar sua destinatária para que no final da leitura ela já esteja completamente envolvida na teia de sensações de Fradique e assim possa realmente ia ao encontro dele, pois esse é o verdadeiro motivo da escrita, convencer Clara (que já no nome nos remete à pureza e ingenuidade) a encontrá-lo.

Por se tratar de Fradique Mendes podemos inferir que todo esse discurso pode não passar de simples persuasão por interesse. A conquista para com o feminino faria sem dúvida parte de todo o processo de criação dessa personagem, e isso é de fato trabalhado por outros efabuladores. O que será visto na conquista de Ana Olímpia com Agualusa por exemplo, o que parecerá mais honesto e menos artificial.

A décima carta é direcionada, novamente, a Madame de Jouarre. Nela Fradique parece dar continuidade a sua promessa sobre descrever suas andanças pela "cidade branca" (mesmo que entendamos que pode não haver uma sequência cronológica nas cartas, já que só há nelas a indicação do mês). Fala sobre suas visitas a casa de um primo, Procópio, que em um "terceiro andar da travessa da Palha" resolveu formar uma organização de pessoas para discussão de filosofia. Fradique apega-se na descrição do amigo, do lugar onde mora. Durante boa parte do documento conta toda a trajetória do dia desse seu primo, cada passo do dia. Parece querer mostrar a madrinha como esse português leva uma vida monótona e sem inquietações: "Nada o inquieta, nada o apaixona." (Ibidem, pág. 205).

Após a descrição desse dia, Fradique começa sua crítica ao Estado português e à apatia social lusitana, representada pela personagem de um frequentador do lugar, Pinho. “[...] portanto o universo todo está perfeito, e a vida perfeita, desde que Pinho, graças as águas de Vidago, conserve apetite e saúde, e que o Estado continue e pagar fielmente o coupon” (Ibidem, pág. 296). Pinho é comparado a uma espécie de animal que na escala evolutiva é de fato pertencente a níveis bastante inferiores: "A necessidade que todo ser vivo tem (mesmo as ostras, segundo afirmam os naturalistas) tem de comunicar com os seus semelhantes por meio de gestos ou sons, é em Pinho pouco existente.” (Ibidem, pág. 206).

Há nela uma critica feroz à identidade lusitana, caracterizando-a como cômoda e principalmente sem inovações, sem inquietações (o que para Fradique seria a mola propulsora para a evolução da humanidade). Não há curiosidade, não há descoberta. Há o mais do mesmo em um lugar fechado e com uma trajetória já delimitada, cotidiana.

As únicas pessoas para as quais Pinho realmente se compadecia e tratava com maior devoção eram também os "prestamistas do Estado", aqueles que como ele enxergavam um mundo sem movimento, recebendo do governo seus juros mensais, possuidor de regalias etc. Com esses 
Pinho divide até mesmo um pedaço de goiabada: "e logo que soube que eu era possuidor de inscrições, um seu semelhante, capitalista como ele, não hesitou, não se retraiu mais só seu dever humano, praticou logo um ato de benefício, e lá veio ruborizado e feliz, trazendo seu doce dentro de um guardanapo" (Ibidem, pág. 208). Pergunta ironicamente à sua madrinha se um cidadão como Pinho seria, para sua pátria, um cidadão inútil. Ele mesmo responde que não. Pois Pinho, como representante dessa apatia lusitana, dessa falta de movimento, de fato reforça um status quo que um país igualmente apático necessita para sobreviver em sua mítica apatia.

Esta carta se assemelha a carta dirigida a Sr. E. Mollinet (oitava), em que Fradique disserta sobre a importância de Pacheco (homem de grande talento!) para Portugal: "Pacheco e Portugal, de resto, necessitavam insubstituivelmente um do outro. Sem Portugal - Pacheco não teria sido o que foi entre os homens: mas sem Pacheco - Portugal não seria o que é entre as nações!” (Ibidem, pág. 188). Certamente há uma semelhança entre essas personagens, e ambas representam essa ordem das coisas em Portugal. Da mesma maneira Pacheco não era inútil ao país, já que também mantinha esse estado das coisas, uma "excrescência sebácea".

Embora essas duas personagens estejam convergindo no sentido dessa ordem, elas divergem no sentido da "atribuição", ou categoria, para manter essa ordem: Pinho pertence, segundo Fradique, à categoria dos lobinhos, já Pacheco pertence à categoria dos elementos mórbidos parasitas:

\footnotetext{
Socialmente Pinho é um lobinho. Ora nada mais inofensivo que um lobinho: e nos nossos tempos, em que o Estado está cheio de elementos mórbidos, que o parasitam, o sugam, o infeccionam e o sobreexcitam, esta inofensibilidade de Pinho pode mesmo ser considerada como qualidade meritória. Por isso o Estado, segundo corre, o vai criar barão. (Ibidem, pág. 209)
}

Por fim, nos é pertinente evidenciar a parte final desta carta. Esta caracteriza sobremaneira o estilo irônico de Fradique. Ao se despedir de sua madrinha, comenta que há dezoito dias não para de chover em Lisboa. Utiliza-se dessa informação para mais uma vez criticar (sem perder a oportunidade de brincar com) o modo de vida lisboeta. Irá ele construir uma arca, assim como a do mito de Noé, e dentre os animais que levará, para uma nova existência, não podeira deixar de levar dois: Pinho de D. Paulina. Assim Portugal poderia se "repovoar com proveito".

A décima primeira carta é endereçada a Mr. Bertrand B., engenheiro na Palestina. Ela é composta como resposta a uma carta mandada por Bertrand. É feita com efusiva surpresa, por saber que o "caro amigo" finalizou seu projeto de estrada de ferro (Caminho de Ferro de Jaffa a Jerusalém) no oriente. A aparente alegria de Fradique se dá pela obra em si. Ou seja, levar uma estrada de ferro, símbolo da modernidade e do progresso, para terras do oriente era para além do próprio progresso, uma metáfora da conquista do ocidente: "E por traz de vos o Progresso hirto 
contra as muralhas de Herodes, todo engonçado, todo aparafusado, também triunfa, esfregando, com estalidos ásperos, as suas rígidas mãos de ferro fundido” (Ibidem, 211).

Sem dúvida esta carta é um manifesto às avessas do progresso ocidental. Que é colocado, não se sabe se propositalmente pelo narrador, logo após uma outra que disserta sobre exatamente a falta de progresso. Os feitos de Bertrand seriam sim exemplos a se seguir por uma pátria que almeja o desenvolvimento, mas Fradique vai além. Coloca-se contra esse progresso em terras que serviriam de "quintal para reflexão". Ou seja, terras de caráter religioso que tivessem uma história milenar mística deveriam ser protegidos.

Fradique se utiliza de uma metáfora bastante pertinente quando se refere ao progresso invadindo terras milenares: "Nem necessitava esse plano com que me deslumbras, todo em linhas escarlates, parecendo golpes de uma faca vil por cima duma carne nobre.” (Ibidem, pág. 211).

Fradique é, como sabemos, e como ele mesmo se nomeia, um "peregrino saudoso desses lugares adoráveis". De fato convém a ele que haja sempre um lugar místico que ele possa visitar quando estiver cansado do caos parisiense. Aquele que é o sinônimo do progresso, (Bertrand) é, a certo momento da carta, é "profanado" por Fradique. Quando fala sobre o lugar que Bertrand está ajudando a destruir: "Mas são fábulas [criadas em tais lugares] que há dois mil anos dão encanto, esperança, abrigo consolador, e energia para viver a um terça da humanidade" (Ibidem, pág. 213). Fradique parece se colocar no caminho da corrente positivista, progressista da época. Enquanto todos falavam sobre cidades, o urbano, o caos, Fradique parece ter a consciência da importância de lugares que se fossem invadidos por uma modernidade estúpida do ocidente certamente perderiam sua essência e até sua função, como disse acima.

Certamente essa personagem aqui cria o escopo (propósito) que Agualusa certamente também percebe. Se Fradique têm um olhar singular às culturas, principalmente às orientais, porque não teria também para com as culturas africanas. Que são certamente também significativas?

Fradique defende seu ponto de vista: "E é penoso que a fumaça do Progresso suje um ar que conserva o perfume da passagem dos anjos, e que os seus trilhos de ferro revolvam o solo onde ainda não se apagaram as pegadas divinas" (Ibidem, pág. 213). Aqui quem fala não é o Fradique do progresso, da crítica política e feroz. Quem fala é o poeta Fradique Mendes. Há um olhar lírico para um lugar de extrema importância religiosa e cultural. Assim também se constitui (guardadas as proporções) a fração fradiquiana de Eduardo Agualusa.

Há nesta carta um Fradique que evidencia os costumes de um povo, e nele vê poesia, lirismo: "Mas a vida íntima, na sua forma rural, urbana ou nômada, as maneiras, os costumes, os cerimoniais, os trajes, os utensílios - tudo permanece como nos tempos de Abraão e nos tempos de Jesus." (Ibidem, pág. 215). Fala de um povo que não necessitaria da materialidade do carvão e do ferro para viver, pelo contrário, tal modernidade seria um retrocesso civilizatório, e para o 
intelectual seria como acabar com um arquivo vivo da essência humana. Como se em um quintal florido fosse erguido um edifício com altura a perder de vista, e que impedisse o sol de se mostrar. Uma civilização escura. "Esta sensação, preciosa para o crente, é preciosa para o intelectual, porque o põe numa comunhão flagrante com um dos mais maravilhosos momentos da História Humana." (Ibidem, pág. 216).

Bertrand passa de mocinho, de herói, para bandido e vilão. Da metáfora do progresso para a metáfora da destruição da História Humana.

[...] esse sítio era um pedaço da Judéa, da Samaria e da Galileia. Se ele for grosseiramente modernizado, nivelado ao protótipo social, querido do século, que é o distrito de Liverpool ou o departamento de Marselha, e se assim desaparecer para sempre e oportunidade educadora de ver uma grande imagem do Passado, que profanação, que devastação bruta e bárbara! E por perder essa forma sobrevivente das civilizações antigas, o tesouro do nosso saber e da nossa inspiração fica irreparavelmente diminuído. (Ibidem, pág. 217)

Sem dúvidas que Fradique é apreciador da modernidade, logo, de suas estradas de ferro, mas, e novamente, nos é perceptível sua distinção dos lugares onde essa modernidade é bem vinda. Aquele irremediável radical moderno achará que onde mais se conseguirem colocar estradas de ferro melhor será. Mas isso é, para Fradique, irracional e leviano.

Há em Fradique a parcimônia na discussão sobre temas da modernidade civilizatória. Ele levanta a teoria do "congênere", da "símile". Deve haver modernização em lugares que são preparados e condizentes: "Um caminho de ferro é obra louvável entre Paris e Bordeus. Entre Jericó e Jerusalém basta a égua ligeira que se aluga por dois drachmas.” (Ibidem, pág. 217).

Com seu tom característico, e como elemento de persuasão, Fradique no final da carta, parece desdizer tudo aqui que afirmou, sobre a importância da essência religiosa e mítica oriental. Diz que "esse homem, por mais intelectual, por mais eruditamente artista, agarraria a sua chapeleira e enfiaria sofregamente para o wagon, onde pudesse descalçar as botas, e dormitar de ventre estendido" (Ibidem, pág. 219). Mas essa retórica é de fato a reafirmação de que Bertrand (engenheiro e acionista!) é peça fundamental na destruição da memória viva da História Humana.

Fradique despede-se imaginando um futuro com todos os lugares míticos cristãos destruídos ou modernizados: “[...] beber um bock e bater três caramboladas no Casino do Santo Sepulcro!" (Ibidem, pág. 219). Uma imagem apocalíptica para um homem realmente preocupado com a poesia que emana dos lugares míticos do oriente, ou preocupado em desfazer seu próprio quintal. Despedese com: "Adeus, monstro!".

A décima segunda carta é endereçada, mais uma vez, a Madame de Jourre. Tem como endereço de remetente a quinta de Refaldes, Minho (quinta que fora reduto de Frades). Explica a 
madrinha o motivo que o leva a "eclesiástica terra": fora ser padrinho do filho mais novo de um amigo, novo dono da quinta. Sutilmente, já desde o início, Fradique critica um dos ritos católicos: “[...] pobre senhor de três palmos que ainda não vivera da alma, e já perdera a alma...” (Ibidem, pág. 220).

Após uma descrição minuciosa da quinta, principalmente no tocante à imagens religiosas do catolicismo, Fradique passa a dissertar sobre a discordância que há entre aquilo que tais símbolos devem suscitar e aquilo que realmente havia na frequência dos frades que ali estavam por grande parte do ano. O lugar deveria ativar sentimento de renúncia daquilo que é mundano e, pelo contrário, os frades que ali frequentavam eram ligados à terra e aos seus prazeres:

Os frades excelentes que nela habitaram amavam largamente a terra e a vida. Eram fidalgos que tomavam serviço na milicia do Senhor, como os seus irmãos mais velhos tomavam serviço na milícia d'El-rei - e que, como eles, gozavam risonhamente os vagares, os privilégios e a riqueza da sua ordem e da sua Casta. (Ibidem, pág. 222)

Aqui mais uma vez uma crítica feroz aos elementos que formavam e professavam pela instituição católica. Parasitas que, a serviço do estado e da igreja (o que em Portugal são quase sinônimos), se aproveitavam das regalias que estes os proporcionavam. Padres que mais se preocupavam com visitas à cozinha e a adega do que à igreja: "Espanejada, arejada, bem catalogada, com rótulos e notas traçadas pela mão erudita dos Abades - só a adega...” (Ibidem, pág. 222). Fradique parece querer mostrar à sua interlocutora o modo de vida dos eclesiásticos, e talvez nela fazer surgir a reflexão sobre a credibilidade que tais pessoas merecem e até mesmo se tais merecem as regalias que têm por custas do Estado. Mesmo com um lugar mascarado com a eucaristia, Fradique afirma que ali fora vivida uma vida de profanidades: "Estava já sabiamente preparada para a profanidade: - e a vida que nela então se começou a viver, não foi diferente da do velho convento" (Ibidem, pág. 224)

Mostrar a beleza da religião sem a figura dos que nela habitam e a corroem é o objetivo de Fradique nesta carta a madrinha: “[...] e estamos então realmente na felicidade de um convento, sem regras e sem abade, feito só da religiosidade natural que nos envolve, tão própria a oração que não tem palavras, e que é por isso a mais bem compreendida por Deus.” (Ibidem, pág. 227). Para Fradique fica claro que a religião é importante para o homem, até mesmo para o homem das luzes, mas há nela personagens que a tornam burocrática e nada essencial, os homens. Na quinta de Refaldes, Fradique pode sentir essa religião pura e sem palavras, e essa sensação é, com retórica bem trabalhada, passada a sua interlocutora.

A décima terceira carta é endereçada novamente a mulher com a qual Fradique troca "juras de amor", Clara. Inicia o documento com o mesmo apelo romântico da primeira carta (quando pede 
para vê-la). Coloca-se em um patamar inferior a sua amada: “em ti tão bela, em mim tão rude. [...] É que, longe de tua presença, cesso de viver, as coisas para mim cessam de ser - e fico como um morto jazendo no meio de um mundo morto.” (Ibidem, pág. 228). Fradique retoricamente se utiliza de uma fala filosófica, que implica a racionalidade no homem, e a desloca para o âmbito do irracional: “<<amo, logo existo!>>” (Ibidem, pág. 229). A verve Dom Juan de Fradique o faz por vezes mentir, ou para não sermos tão duros com o conquistador, o faz por vezes recriar a sua própria realidade com o fim de conquistar uma mulher.

De fato Fradique Mendes sentia os prazeres do mundo como poucos, conhecia lugares como poucos e em cada lugar que estava deveras estava, ou seja, sentia cada cultura, cada momento deste “estar em outros sítios". Para que a conquista de Clara seja eficaz, Fradique afirma: "E não foi só a minha realidade que me desvendaste - mas ainda a realidade de todo este Universo, que me envolvia como um ininteligível e cinzento montão de aparências” (Ibidem, pág. 229).

O exagero romântico, que podemos entender subliminarmente como crítica à própria escola do início do século XIX, por parte do efabulador Eça de Queiroz, é aqui tão acentuada que não basta para Fradique colocar Clara ao mesmo patamar de santas e deusas. Ela é ornadamente colocada acima delas: "Mas que! A pobre Vênus só oferecia a serena magnificência da carne. De todo lhe faltava a chama que arde na alma e a consome." (Ibidem, pág. 230).

Há uma cena que Fradique descreve que acreditamos ser plausível de análise nesta carta. Comenta com a amada que tem uma gravura em que há um Satanás carregando uma santa para o abismo. E nos olhos dessa santa há somente alegria a paixão:

Possuo uma velha gravura que é um Satanás, ainda em toda a refulgência da beleza angelical, arrastando nos braços para o Abysmo uma freira, uma Santa, cujos derradeiros véus de penitência se vão esgaçando pelas pontas das rochas negras. E na face da Santa, através do horror, uma tal alegria e paixão, tão intensas - que eu as apeteceria para ti, oh minha Santa roubada! (Ibidem, pág. 233)

Metaforicamente podemos encaixar essas duas personagens míticas da gravura nas duas personagens da carta. Fradique se coloca com a figura do mal, Satanás (lembrando do epíteto: poeta satânico), e coloca sua amada como a imagem da santa. Este levando aquela para a perdição. Há uma relação com traços semelhantes àqueles que os poetas ultrarromânticos tinham com suas amadas. Com evidenciação das dicotomias que os representavam: Bem x Mal, Diabo x Santo, Morte x Vida: "Só posso deixar de te amar - quando deixar de ser".

A antepenúltima carta, de número XIV, é endereçada à madrinha, Madame de Jouarre. Escrita de Lisboa e mais uma vez conta a ela sobre as suas experiências na cidade branca. Descreve fatos e deles cria e recria uma Lisboa que, por mais criticada, habita em Fradique. Nesta missiva temos uma indicação que Eça, o narrador, publica as cartas respeitando uma ordem cronológica de 
escrita: "Naquela casa de hóspedes da travessa da Palha [...]" (Ibidem, pág. 234). Fradique faz entender que a madrinha já conhece o local, pois fora tratado na carta de número XII. Certamente não podemos afirmar que todas as cartas seguem a mesma ordem, mas aqui há uma indicação que podemos, se nos for pertinente, lê-las assim.

Mendes inicia a carta falando sobre um padre que conheceu assim que chegou de Refaldes, mas não se trata de um padre ortodoxo, mas sim um "tipo interessante e psicologicamente divertido". O que chamou a atenção de Fradique, e que é mote para mais uma crítica àqueles que compõem o clero, "foi a sua maneira de conceber o Sacerdócio [...]. Para ele o Sacerdócio não consiste de modo algum uma função espiritual - mas unicamente e terminantemente uma função civil.” (Ibidem, pág. 236).

Como funcionário público o padre "pitoresco" encarava suas atribuições: "As suas relações portanto não são, nunca foram, com o céu (do céu só lhe importa saber se está chuvoso ou claro) mas com a Secretaria da Justiça e dos Negócios Eclesiásticos.” (Ibidem, pág. 236). Este padre vai na mão contrária à apontada por Fradique quando em sua última carta a madrinha, em que disserta sobre a essência das religiões. O padre que Fradique conheceu personifica os entraves que a burocracia religiosa cria para os fiéis, até mesmo dificultando, propositalmente, o encontro com essa essência religiosa.

Um padre que fazia burocraticamente aquilo que mantinha a igreja no seu devido lugar de destaque: "batizar, confessar, casar, enterrar os paroquianos". Além de promover a manutenção de um Estado (já que via a Igreja como o próprio Estado). E mesmo cumprindo essa burocracia eclesiástica, e levando em si a Igreja, "nada sabe do Evangelho - que considera todavia muito bonito" (Ibidem, pág. 238).

Fradique diz que havia entre eles "noites amigas" e que o padre o "divertia". A existência desse padre é para Fradique como a constatação de que tudo aquilo que disse para madame de Jouarre é a mais pura verdade. Já que pode sentir a essência da religião sem ter por perto sequer uma figura que pudesse fazer a "ponte". O padre bonachão certamente, no discurso fradiquiano, acaba por negar a própria instituição católica, e também sua ineficiência e sua inutilidade. Já que na figura do padre há a ignorância e somente a burocracia de um funcionário público.

A penúltima carta é endereçada a Bento de S. Já nas primeiras linhas Fradique se coloca contra as ideias do seu interlocutor: "A tua ideia de fundar um jornal é daninha e execrável" (Ibidem, pág. 243). Fradique acredita que um jornal atiça os "Juízos ligeiros, a Vaidade e a Intolerância”, coisas que matam uma Sociedade. O autor da carta ataca o pavoroso hábito da imprensa de provocar os Juízos ligeiros, a não reflexão profunda dos casos, a superficialidade e a parcialidade desta mídia. Talvez por isso que quando tomamos, nós leitores, contato com aquilo que Fradique pensava e refletia sobre a vida, não lemos notas, ou crônicas, ou colunas de jornal 
assinadas por Fradique, mas sim suas cartas que, segundo Fradique, é a melhor maneira de ter acesso a o que pensa um homem.

Esta carta é de fato uma das mais críticas para principalmente os leitores que têm contato com ela no século XX e XXI. Obviamente sabemos que Eça de Queiroz não tinha por objetivo criticar aquilo que poderia vir, até porque não se sabe o que possa vir. Mas parece ser escrita para o que percebemos hoje no século XXI. Fradique critica seu tempo, e nele "todos nós hoje nos desabituamos, ou antes nos desembaraçamos alegremente, do penoso trabalho de verificar. É com impressões fluidas que formamos as nossas macissas conclusões. [...] nos contentamos com boato." (Ibidem, pág. 244).

Tão atual é a proposta de Fradique em criticar a mídia como o faz que tudo isso se encaixaria perfeitamente no poder que hoje (e no século XIX) as mídias têm em criar bandidos e mocinhos, com simples boatos, notas de roda pé, manchetes sensacionalistas. E toda uma população, até mesmo a intelectual, se rende a tais manifestações superficiais da realidade: "Principalmente para condenar, a nossa ligeireza é fulminante. Com que soberana facilidade declaramos - <<Este é uma besta! Aquele é um maroto! > Para proclamar - <<É um gênio! >> ou $<<$ É um santo!〉> oferecemos uma resistência mais considerada.” (Ibidem, pág. 245). Certamente o compatriota Pacheco, personagem da carta enviada ao Sr. E. Mollinet teve uma mãozinha dos jornais para ter carregado sempre o epíteto de "homem de imenso talento!": "Por um gesto julgamos um caráter: por um caráter avaliamos um povo" (Ibidem, pág. 245).

Fradique conta ao amigo Bento de S. o caso de um amigo inglês, que por ter conhecido apenas um francês, que na casa de seu sogro surrupiava os charutos, colocou em mente que nenhum outro francês teria caráter, ou melhor, que todos os outros franceses, assim como o único que conhecera, não seriam dignos de confiança. Fradique coloca em discussão as generalizações que se faz sem antes haver uma pesquisa séria de um povo ou de um grupo de pessoas. Isso corrobora o fato de Fradique ser contra jornais que fazem exatamente esse papel.

Tal discussão levantada aqui por Fradique fortifica, indiretamente, sua próxima efabulação, estamos falando especificamente a de José Eduardo Agualusa. Um viajante que tem um olhar aguçado e principalmente não-generalizador tem muita serventia para um autor que pretende desmitificar, desgeneralizar a figura e a imagem que se tem da África. Aquela de lugar sem leis, credo e principalmente sem organização social. Por meio da intromissão de Fradique em terras preconceituozamente pintadas, Agualusa abre a possibilidade para um olhar mais completo, e lírico, sobre as originais formações e desejos de um povo que vive em uma complexa malha civilizada e civilizadora.

A desgeneralização pode ser observada também na obra de Venâncio, a começar pela própria proposta de produção de um romance que é paródia do próprio romance, e ao mesmo tempo um 
romance ensaístico. Além disso há uma personagem rememorada, Fradique Mendes, por meio de seus descendentes que, colocando à tona suas histórias, parecem fazer com que esse ser "original português" pudesse fazer as pazes com seu lugar. Desmitificando uma Lisboa antiga, antiquada, presunçosa e até mesmo passiva, e mostrando uma Lisboa mais moderna e complexa, também nas relações complexas que as próprias personagens estabelecem entre elas ou entre si mesmos (conflitos psíquicos). Sem dúvida que um olhar fradiquiano é desgeneralizador. E por isso alguns dos importantes efabuladores se aproveitam e entram nesse jogo, utilizando essa característica como uma das regras principais.

Assim como Fradique levanta em outras cartas o poder da palavra, aqui podemos perceber que indiretamente trata o mesmo tema. Afirma que um jornal levaria a dois grandes pecados, o da generalização, tratado acima e o da vaidade. Com exemplos e retórica aprimorada defende tais pontos de vista. Coloca que a palavra impressa tem o valor, ou poder de mudar, ou reverter, ou formar valores morais e éticos. A palavra, não só dita, pode ser, e é, usada como arma frente aquilo que se quer modificar: "Desde que penetras na batalha, nunca poderás admitir que a Razão ou a Justiça ou a Utilidade se encontrem do lado daqueles contra quem descargas pela manhã a tua metralha silvante de adjetivos e verbos [...]" (Ibidem, pág. 252).

Ao seu modo, Fradique finaliza o texto endereçado ao amigo Bento de S. com os dizeres: “Ora esta carta já vai, como a de Tibério, muito tremenda e verbosa, verbosa et tremenda epistola; e eu tenho pressa de a findar, para ir, ainda antes do almoço, ler os meus jornais, com delícia. - Teu Fradique." (Ibidem, pág. 254). Acaba por brincar com o amigo, que muito provavelmente irá achálo pândego. Ao final das duras críticas Fradique parece amenizar o discurso, por simples traço de retórica. Como um homem pode falar tão mal dos periódicos e no final desse discurso se mostrar dependentes dele? A resposta é fácil: Homens como Fradique não veem no jornal verdades absolutas, ou substrato para formarem suas opiniões, pelo contrário, estes homens veem no jornal substrato à criticar, mais um elemento humano que possa ser cientificamente analisado e desmascarado.

A última carta de A Correspondência de Fradique Mendes é endereçada a Clara. No decorrer das cartas enviadas a ela, mesmo sem saber se há uma linear cronologia, parece-nos que a relação dos amantes vai se tornando mais intensa: "Que outro princípio governa e mantém a minha vida se não o teu amor?” (Ibidem, pág. 255). Este documento versa sobre a importância, para Clara, de receber cartas de seu amado. Parece-nos que Fradique coloca em evidência, e discussão, novamente a importância da linguagem (escrita). Compara as cartas que envia a Clara com “certificados de amor": "Realmente necessitas ainda, cada manhã, um certificado, em letra bem firme, de que a minha paixão está viva e viçosa [...] (Ibidem, pág. 255). O poder do "verbo" como documento ou como maneira de se tornar eternas as palavras e os sentimentos é uma constante na 
obra de Fradique Mendes.

Portanto, o que vemos aqui foram os traços que marcam a personagem Fradique Mendes, aquilo que inicialmente Eça de Queiroz levantou e elaborou e que foi, por todas as efabulações aqui escolhidas para análise, respeitado. Assim veremos quando analisarmos as próximas efabulações, primeiro a de Vidal, depois Agualusa e, por fim Venâncio (respeitando-se uma ordem cronológica). 


\section{II - OUTRAS EFABULAÇÕES}

\section{1- FRADIQUE DO JOVEM VIDAL: O MESTRE DA CONTRA-REVOLUÇÃO}

Frederico de Sá Perry Vidal apresenta uma retomada da personagem Fradique Mendes em um pequeno romance publicado em 1950. Há somente uma edição dessa obra e, pelo que podemos perceber, com pouquíssimos exemplares.

Além de poucos exemplares essa obra não conta com qualquer fortuna crítica. Vemos que esse trabalho vai ser o primeiro a deitar os olhos sobre o único filho de Fradique Mendes.

O prefácio da obra, escrito por João Ameal ${ }^{11}$, parece trazer uma pequena análise da personagem Fradique Mendes de A Correspondência. Longo, traz ao leitor um pouco da trajetória fradiquiana e levanta questões sobre principalmente a motivação de Eça para a criação do poeta.

Afirma o autor do prefácio que Fradique é elaborado, para uns, como exemplar do século XIX e, para outros, seria o autor de Lapidária "o libelo contra uma época de superficialidade, de pedantismo e de artifícios - << a vingança de Eça contra seu século>>” (VIDAL, 1950, pág. 9).

Acreditamos que ambas motivações são verdadeiras, uma vez que Fradique seria um exemplo de homem contestador de seu tempo. Como afirmou Venâncio: "tudo aquilo que nós portugueses poderíamos ser" (Entrevista).

Na primeira linha de seu prefácio, o autor nos traz uma informação que corrobora aquilo que temos levantado: a de que Fradique Mendes é passível de continuidade (se não livre, como afirma Ameal, condicionado a um jogo, a regras de produção, já que todas as efabulações exibem uma coerência entre as personagens, que se constituem, no final, como o mesmo). "Um dos grandes temas, entre muitos, que Eça de Queiroz deixou à nossa livre e permanente especulação - foi o caso de Fradique Mendes. Ou antes: o mistérios de Fradique Mendes.” (Ibidem, pág. 7).

Ameal, nome importante na literatura portuguesa, parece apresentar o jovem autor Perry Vidal e, além disso, durante o prefácio, autorizá-lo a dar continuidade à construção da narrativa fradiquiana. Ao leitor que não conhece, ou que não se recorda de ter lido algo sobre Fradique, Ameal presta o serviço de apresentá-lo.

\footnotetext{
${ }^{11}$ João Francisco de Barbosa Azevedo de Sande Aires de Campos, conhecido com o pseudónimo literário João Ameal, (23 de Agosto de 1902 - 23 de setembro de 1982) foi um jornalista e escritor politico, e historiador português. Era o segundo visconde e terceiro Conde do Ameal. Licenciado em Direito, deputado à Assembleia Nacional e procurador da Câmara Corporativa, deixou vasta obra no domínio da historiografia, da ficção e da crítica. A sua História de Portugal, um trabalho multi-volume publicado pela primeira vez em 1941 foi galardoada com o Prémio Alexandre Herculano, em 1943. Neto do famoso humanista e colecionador de arte João Maria Correia Ayres de Campos, $1^{\circ}$ Conde do Ameal, publicou mais de vinte livros em diversos gêneros. (http://www.geneall.net/P/per_page.php?id=34006)
} 
Traz o autor do prefácio, como já foi citado, a teoria de que há nos críticos de Fradique parcelas de verdade. Mesmo encontrando nessa personagem características singulares, Fradique é de fato a união de todas elas: daquilo que o brasileiro Álvaro Lins acredita - a vingança de Eça contra o seu século; daquilo que Antônio Sardinha levanta - melancolia e insatisfação, mestre da contra revolução.

Além de Fradique ser montado pelos críticos com "partes da verdade" os próprios efabuladores partem desse pressuposto para a composição do "homem do século". Cada um com um trecho da "verdade" de Fradique, de sua vida. Uma linha contínua que fora cortada e dividida, e cada efabulador tomou posse de um trecho dela.

Quando tratarmos de Fernando Venâncio traremos à tona a problemática das "meias verdades implicam meias mentiras", quando tratarmos do que verdadeiramente produz o jornalista Martinho, verdades sobre Fradique, ou mentiras sobre ele?

Ameal sugere à leitura que se deve fazer daquilo que "Fradique Mendes" produziu: "Pareceme errado considerar Fradique com os nossos olhos de hoje, quando deve ser visto com os olhos de um contemporâneo de Eça de Queiroz” (Ibidem, pág. 9). Além de perigosa é contraditória, pois Perry Vidal publica algo sobre Fradique mais de cinquenta anos depois da publicação queirosiana; principalmente levando em consideração que Fradique carrega em si a contemporaneidade e, como afirma novamente Venâncio, "possa até mesmo extrapolar a linha do tempo e trazer o elemento futuro", já que sempre esteva além de seu tempo.

De fato é possível ler Fradique com olhares de qualquer contemporaneidade, por isso essa personagem, por motivos que cada efabulador elenca, perpassa, ou preferimos "flana" entre textos e épocas. E quando trouxermos o livro de Venâncio isso ficará muito claro, pois nele há a visão de uma personagem contemporânea (Martinho) frente essa instigante personalidade do século XIX.

Ameal conta sinteticamente sobre a inspiração de Perry Vidal para a criação de sua obra, ela viria de estudos e reflexões de Antônio Sardinha: "Certamente, se Fradique um filho, o filho desse filho responderia com um ato pleno de fervor à sua renúncia espontânea e desdenhosa" (Ibidem, pág. 12). Resolve então Vidal traçar os caminhos do único filho de Fradique Mendes, que tivera com Vária Lobrinska - "a maravilhosa Libuska de quem tanto falava à sua madrinha e confidente Madame de Jouarre".

O autor do prefácio traz uma pequena e rápida trajetória deste único filho de Fradique e levanta questões que incitam o leitor: "Há ingenuidades numerosas neste pequeno volume? Surge um texto insistente a influência direta de Eça de Queiroz?” (Ibidem, pág. 15). Há sim influências do estilo queirosiano, há ingenuidade, e há uma preparação para um projeto literários maior?

De fato $O$ único filho de Fradique Mendes não traz uma qualidade literária extraordinária. É sim um documento ou a tentativa ficcional de um autor que ao escrever a obra somava somente seus 
quinze anos. (Fato evidenciado pelo prefaciador, que já havia tomado contato com a obra e, acreditamos, havia percebido essa falta, ou essa não chegada a um patamar plausível de literariedade).

Contudo vale a pena vistas mais aprofundadas principalmente no tocante ao nosso estudo sobre a continuidade de um jogo que começa a se estabelecer aqui, e que será continuado por vários autores, não só na literatura, mas também na imprensa.

Após o prefácio há uma carta ao leitor, assinada pelo próprio Vidal. Nela há uma informação que é para nós prova daquela atualidade fradiquiana de que falamos. Vidal vai reviver Fradique por meio de seu filho, tática de jogo também adotada por Fernando Venâncio, quando traz rememorado um Fradique pela voz de seu neto e de outra descendente (Dr. Cristiano e Leonor). Então, trazer aqueles que de alguma maneira são fruto das aventuras fradiquianas é indiretamente trazer Fradique, pois a cada momento tais personagens descendentes rememoram-no por perspectivas distintas.

Inicia o documento modestamente, afirmando que em nenhum momento tenta produzir algo comparável a aquilo que deu início ao heterônimo fradiquiano. Parece preferir que sua obra fique à sombra de A Correspondência, mas ficar a sombra de uma grande obra é ao mesmo tempo grande expectativa, já que não há a pretensão de se levantar um castelo, fica-se a sombra dele.

A carta ao leitor nos prova, em certa maneira, um desejo contínuo de atualização da figura fradiquiana. Já que Eça não o criou como entidade mítica, que carrega em si a eternidade, fora de fato um mortal; os efabuladores, começando por aqui, tentam eternizar, atualizar a figura: "Foi sem dúvida ao ler essa peça literária [Correspondência de Fradique Mendes] que me veio à mente a ideia de algo escrever sobre o que seria um Fradique Mendes do tempo presente e por isso resolvi fantasiar" (Ibidem, pág. 17).

Parece querer trazer, como ele mesmo diz, o "espírito" fradiquiano na figura de seu filho. Cabe ao leitor então decidir se essa obra fica mesmo à sombra do grande castelo que foi $A$ Correspondência.

No capítulo I, Vidal inicia o texto trazendo Eça de Queiroz como personagem, aquele Eça narrador da primeira parte de A Correspondência. Indica ao leitor o momento em que este recebe a carta de um advogado informando que Vária Lobriska havia morrido. Nela há também a informação de que o único filho de Fradique e de Lobriska acabara seus estudos na Inglaterra e estava a caminho de Portugal.

Parece Vidal iniciar seu texto a partir de um “ponto final”. Fradique morrera, Vária Lobriska morrera, inicia-se um novo ciclo e esse deve ser conduzido por dois elementos, o próprio narrador em terceira pessoa e as mãos hábeis de Eça de Queiroz, que deve conduzir o único filho de Fradique Mendes nos seus "primeiros passos na vida de homem”. 
Vidal dá continuidade ao processo narrativo fradiquiano. O filho de Fradique deverá conhecer Portugal pelas mãos de Eça. Seria como apresentar Portugal ao próprio Fradique Mendes. Tentar fazer com que esse país não se torne tão arredio para o filho como fora para o pai. Uma tentativa de se fazer as pazes com o lugar.

É dado a Eça uma importância muito grande na obra, já que este fica encarregado de rememorar a figura do pai para o filho. É Vidal que conduz a narrativa, mas é Eça que conduz, como lhe é de direito, aquilo que resultou do "homem do século".

Se Fradique estava cada vez mais distante de sua terra (mesmo que ela fizesse parte dele), seu filho seria apresentado a ela e nela teria sua "formação masculina".

Ao receber a informação que seria responsável por receber o "menino", Eça "tirou a luneta e elevando os olhos sorriu; na sua frente via a parede e nela um belo retrato, corpo inteiro, do autor das <<Lapidárias >> (Ibidem, pág. 20). Ver e sentir a presença desse menino traz a Eça a figura do pai, e tudo aquilo que ele representou.

Cria-se na narrativa a expectativa do que virá de Inglaterra ao contato de Eça, um pequeno Fradique?

A narrativa apresenta um ritmo bastante acelerado, as ações são quase sobrepostas, o autor não prepara terreno para, parte por parte, indicar as intencionalidades, as sensações, os ambientes. As coisas acontecem rapidamente. Acreditamos que por se tratar de uma obra curta (92 páginas) mesmo repleta de informações e cenas - a narrativa obrigatoriamente se torna rápida.

Diferenciando-se do estilo queirosiano e fradiquiano. Podemos dizer que modernamente a narrativa é construída. Um novo Fradique (ou sua nova fração) talvez mereça um novo estilo literário, mesmo que com alguns problemas de construção (como diz Venâncio - "talvez não haja maturidade literária para Vidal ainda nesse momento de sua vida”).

Em poucas páginas a narrativa nos leva do momento do recebimento da carta ao primeiro contato com o filho do poeta satânico. Á porta do hotel Eça pergunta pelo rapaz e é informado que o “Príncipe de Palidoff” está hospedado em Lisboa. Esse tratamento faz com que a expectativa de Eça em relação ao "menino" se modifique, também, a nosso ver, modifica-se a expectativa do leitor, que logo no início da obra tenta criar a imagem do "garoto" a figura do pai.

O grande romancista, que tinha idealizado um jovem folgazão, robusto, esbanjador, ao ouvir os extravagantes sons nobiliárquicos do pomposo título, deixou cair todas as suas ideias e preparava-se para enfrentar um senhor majestoso, não de cabaia chinesa como encontrara o pai, havia anos, mas envolto nas vestes roçagantes da corte russa. (Ibidem, pág. 22)

Durante a narrativa Vidal nos traz, mesmo que indiretamente, uma semelhança entre aquilo que ambos os homens vão provocar em Eça: admiração e deslumbramento. O Príncipe de Palidoff 
antes mesmo de aparecer (mesmo só no âmbito da especulação) causa em Eça deslumbramento, até mesmo pelos aposentos; mesma sensação que o inesquecível Fradique causava neste homem. Parece-nos que a mesma áurea de superioridade transita entre as personagens dessas duas obras. E Eça, em ambas, se torna espectador dessa beleza, mesmo que em uma ele seja condutor de parte da narrativa, e em outra seja conduzido.

Assim como o pai, o Senhor de Palidoff, sentado a uma chaise, lia o Times. E também tinha um mordomo que parecia de confiança. As peças desse jogo parecem ser as mesmas, somente colocadas em um tabuleiro em outras disposições.

O encontro de Eça com o filho de Fradique Mendes nos estabelece o início de uma das regras do jogo, a introdução de "novos escopos documentais" que aparecem em todas as efabulações. Isso dá combustível para novos motes e entradas para novas narrativas. Eça edita suas cartas daquilo que recebeu de Fradique e daquilo que recebeu de seus camaradas, que também se comunicavam com o autor de Lapidárias.

O narrador de Vidal traz à tona o escopo deixado como herança para o Príncipe da Palidoff (o cofre do século XV, a tão conhecida "Vala Comum" das obras de Fradique), de sua mãe, Madame Lobriska. Agualusa traz correspondências secretas que são enviadas à Eça por Ana Olímpia, amor fradiquiano dos trópicos. E Venâncio parece amarrar toda essa narrativa ensaisticamente, mas não deixa de trazer seu novo escopo, uma caderneta com novas informações sobre Fradique, deixado pelo neto desse homem, o que seriam os "esquemas" de Fradique (que na verdade são códigos para o Rei).

Narrativamente um novo escopo não esgota o assunto e dá à narrativa uma nova proposta, ou até mesmo uma condução para as ações.

Sobre o escopo tratado pelo narrador de Vidal, o que abre a expectativa desse conteúdo, temos: Grande honra a minha, em conhecer V. Ex.; não me era estranho o seu nome; nos papéis de meu pai encontrei muitos que falam de V. Ex.; as suas cartas estão entre mas mais ricas páginas do arquivo que minha mãe me legou. (Ibidem, pág. 22).

Nesse mesmo capítulo, o narrador nos dá a indicação dessa continuidade narrativa, aquele fio do qual falamos:

[...] sei que deseja ser o continuador do seu pai, e que como ele também muito quer a esta bela terra portuguesa [...] se como ele conseguir visitar todas as partes do mundo; se como ele souber interpretar tão bem todas as civilizações, todas as religiões; até às mais simples maneiras de ver e de pensar. (Ibidem, pág. 23).

O objetivo do sr. Palidoff é de fato chegar ao nível do pai. Nesse processo há uma característica que nos chama a atenção: há um processo em sentido contrário de descobertas. 
Explico: levando em consideração que o ponto original seria Lisboa, o pai faz uma trajetória de dentro pra fora, e nela muitas vezes nega sua terra, e a critica de maneira feroz. Já o filho parece seguir uma trajetória contrária: faz um caminho de fora pra dentro. Vem da Rússia e da Inglaterra (onde conclui seus estudos) e começa a conhecer aquele ponto original:

- Penso ir daqui a um mês viajar para o Norte, e então visitarei todo o Minho, aonde faço tenção de me dedicar às particularidades do povo, o que aliás pretendo fazer em todas as províncias. Sabe que tenho uma especial predileção pelo folclore? E continuando: - Gosto imenso dos hábitos e dos costumes das populações e, de Deus o permitir, tenho vontade de fazer uma espécie de museu regional particular. (Ibidem, págs. 23 e 24).

Após ter tido conhecimento técnico sobre estudos antropológicos na França e na Inglaterra, o Príncipe de Palidoff quer colocá-los em prática na terra de origem de seu pai. Quer descobrir, mapear, e instaurar museus (o que certamente é a expressão da não-morte) em uma terra que precisa ser (re)descoberta.

O contato entre Palidoff e Eça é sempre regado a arte e deambulações, tornam-se ambos flaneurs. Redescobrindo um ambiente que pelo menos para Eça já é bem conhecido.

Sempre quando Vidal se refere a Eça, se utiliza de epítetos como "o escritor de Os Maias", “o escritor de A Ilustre Casa de Ramires", ou "o escritor de O Mandarim”. Parece oferecer ao leitor também não só a importância do filho de Fradique, mas também a importância do escritor que o segue. E não só isso, durante toda a trajetória do texto, Eça, escritor renomado, parece se entregar aos brilhos de um "garoto". Evidenciar a importância de Eça é ao mesmo engrandecer o próprio protagonista, o Príncipe de Palidoff.

Vão para o Mosteiro dos Jerônimos, lá Palidoff Mendes é "levado pelo braço de Eça de Queiroz" e "percorreu e igreja, a sacristia, o claustro, o coro e a própria torre moderníssima; tudo admirou, tudo apreciou. (Ibidem, pág. 26). Dizemos redescoberta porque parece-nos que no processo de descoberta de Palidoff há indicações que Portugal sempre tivera habitado aquele homem, já que tivera, certamente, contato com tal terra pelos escritos do pai. Seria como um processo narrativo de dejavu.

Portugal falava-lhe ao coração: “[...] Portugal era por ele mais amado que a própria Inglaterra, onde recebera as luzes da sabedoria. Portugal falava-lhe ao coração; as suas riquezas faziam-no tão orgulhoso como os escritos paternos. (Ibidem, pág. 26). Parece haver uma lembrança genética em Palidoff.

Se no primeiro capítulo Vidal cria expectativa pelo encontro dos personagens, e de maneira rápida mostra como isso acontece, num segundo momento narra como o contato entre ambos começa a se estreitar: 
[...] tornaram-se os dois amigos inseparáveis, discutindo na intimidade, ora os trajes negros, característicos dos estudantes portugueses, ora as obras de Voltaire [...] E assim os seus espíritos se sentiam sós quando separados; o bom Fradique chamava-lhe excelso Mestre e Eça, o grande escritor, o diplomata subtil, sorria e negava. (Ibidem, pág. 29)

Existe aqui uma semelhança entre as figuras de Fradique Mendes e de seu filho e, além disso, uma semelhança entre as relações destes com Eça. Assim como em A Correspondência, Palidoff e Eça se separaram por alguns instantes, mas nesse processo, agora, Fradique Palidoff fica (nos seus estudos de antropologia) e Eça sai (o autor remonta a profissão do escritor na diplomacia, na França).

Enquanto um olha para dentro, o outro olha para fora. E enquanto Fradique Palidoff aprende e se surpreende com aquilo que descobre na terra de seu pai, inicia uma correspondência entre os dois grandes amigos: "a sua correspondência cruzava-se constantemente desde a cidade bela do Louvre até às margens poéticas do Mondego [...]” (Ibidem, pág. 30).

Esse segundo capítulo traz uma informação que leva a narrativa para um rumo incerto, pois ao mesmo tempo que o contato entre Eça e Palidoff se intensifica, finaliza, pois há a morte do escritor em 16 de agosto de 1900.

É nesse capítulo que aparece pela primeira vez, o que aproxima esta obra às Cartas, o narrador se posicionando politicamente frente ao contexto de sua época, e como afirmado anteriormente, fato pertinente principalmente quando se está trabalhando uma personagem que carrega em si o tom da crítica (também o filho):

[...] era a mais bela entre as casas aristocráticas dessa Lisboa de então, dessa Capital do Reino constitucional, com bons reis e piedosas rainhas, mas maus ministérios, governos que iam tornando pouco a pouco num caos este país de tão nobre tradições, de tão vasto e importante império ultramarino. (Ibidem, pág. 33)

Aqui uma indicação histórica sobre a passagem para o período republicano, em que D. Calos I fora assassinado pelos adeptos deste regime e da passagem de D. Miguel II para definitivamente a República Portuguesa. Como não há indicação cronológica, inferimos que seja uma crítica a esta nova República. Vidal traz aquilo de praxe entre os efabuladores lusitanos, a rememoração de feitos históricos e principalmente um amor exacerbado por essa história. Em Eduardo Lourenço:

Todos os povos vivem, mais ou menos, confinados no amor de si mesmos. Mas a maneira com os portugueses se comprazem nessa adoração é verdadeiramente singular. Seria absurdo pretender que um povo entre outros e, ainda por cima, um pequeno povo, possa estar fora ou escapar a esse maelstrom a que chamamos História. (LOURENÇO, 1999, pág.10) 
Durante esse capítulo, o autor conta sobre a trajetória de Palidoff (que se nomeara após a naturalização portuguesa como Carlos Fradique Patendorff Mendes), como se torna membro importante da aristocracia portuguesa, como continua enriquecendo e principalmente informa que ele se torna diplomata (mesma profissão daquele que fora seu Mestre, Eça de Queiroz).

No capítulo seguinte, o narrador conta sobre uma festa oferecida por Fradique, nela "Podia dizer-se que tudo o que havia de bom na capital do reino ali estava representado [...]" (VIDAL, 1950, pág. 36). O universo da perfeição (artística e humana) parece transitar ao redor tanto da personagem Fradique Mendes com Eça, quando da personagem de Vidal.

Há durante todo o jogo narrativo um universo daquilo que "se deve fazer" ou daquilo que se "poderia ser"; e entendemos que cada efabulador, mesmo dentro de suas propostas, transitam por essa vontade (crítica) do que "deveria se fazer".

Eça traz aquele que seria o português perfeito, o "homem do século", o narrador traz aquele que é resultado deste, logo, seu espelho. Agualusa traz aquele que tem o poder de desmitificar, quebrar paradigmas e, por fim, Venâncio arremata um jogo por meio de um texto ensaístico e parodístico, que coloca em questão a forma e o conteúdo daquilo que fora, e é, Fradique Mendes.

O quarto capítulo do livro de Vidal inicia-se com a criação de uma expectativa de qual seria o conteúdo do cofre deixado por seu pai. Após abrir, ler algo e emocionar-se, Fradique é comparado a um Deus, assim como fora seu pai em A Correspondência de Fradique Mendes: “[...] olhos de alguém que o visse sem ser reparado, como que um Deus vestido à atualidade [...] parecia um ser que do Olimpo glorioso viera a visitar Portugal” (Ibidem, pág. 42).

Eis a proposta de Vidal e de todos os outros efabulares, notamos que para se adequar ao jogo deve-se buscar algo de atualidade, de modernamente crítico na figura de Fradique ou em qualquer uma que rememore este homem, mas ao mesmo tempo torná-lo um "ideal", como dito, daquilo que se deveria ser.

Destoe talvez de toda essa proposta as duas obras mais modernas, a de Agualusa, que o trata de maneira mais humanizada, e a de Venâncio, que o trata de maneira paródica e às vezes caricata. Ambos os tratamentos serão trabalhados quando das partes que lhes cabem (2.2 e 3.1).

Vidal, dentre os efabuladores, parece deixar mais óbvia a imagem de representante luso por uma metáfora bastante pertinente, a diplomacia:

Interessava-lhe, sim, partir, partir a cumprir o seu dever de diplomata, a desempenhar o cargo honroso de representar Portugal no Estrangeiro e intimamente jurava que o faria com dignidade e com prazer, que seria um cidadão útil à Pátria, longe dela, que defenderia seus interesses, que se empenharia em 
elevá-la ao plano das primeiras potências europeias. (Ibidem, pág. 42 e 43).

Além de trazer novamente a utopia da perfeição, com o desejo de figurar entre os países hegemônicos da Europa, há aqui a exteriorização máxima da representação do homem lusitano. Representar o País para o estrangeiro é de fato a chance de demonstrar a grandeza lusitana e principalmente aquilo que o País pode oferecer em termos de cultura (lembrando dos estudos de antropologia do Senhor Palidoff). Tentar desmontar a imagem periférica (real) que Portugal construiu pós-navegações do século XV e XVI.

Ao "mais modernos dos continentes" fora mandado Carlos Fradique. Fora representar seu país na cidade do Rio de Janeiro. E sobre este lugar afirma o narrador: "Terra filha da Pátria Portuguesa, um dos mais vastos e importantes Estados mundiais de hoje, um país admirado e respeitado pelo seu desenvolvimento intelectual, comercial e industrial, pela inteligência e retidão dos seus filhos." (Ibidem, pág. 44).

O Rio de Janeiro aqui é pintado com as cores da oportunidade e do sonho. Um Eden econômico e de felicidade: “[...] partem para as sonhadoras terras da América do Sul [...]” (Ibidem, pág. 45).

De maneiras distintas são as viagens que levam Fradique Mendes, ou seus descendentes, ao novo mundo. Vidal transporta Palidoff em uma viagem de representação diplomática portuguesa, oportunidade em que ele pode passear "pelos decks, cumprimentando aqui e ali as muitas relações que tinham afluído" (Ibidem, pág. 46). De fato viagem bem diferente que a enfrentada por Fradique Mendes quando de sua ida ao Brasil dentro de um navio negreiro, o Nação Crioula.

Em condições sub-humanas fora colocado por Agualusa. E certamente essas condições encaixam-se na proposta agualusiana de crítica às condições em que os escravos eram colocados quando transportados. Colocar um português da estirpe de Fradique nessas condições é dar de volta aquilo que os próprios lusitanos ofereceram aos negros. Assunto que será esmiuçado quando do capítulo pertinente. Por hora tenhamos a agradável viagem do senhor Palidoff.

Já no Rio toma contato com pessoas ilustres da cidade, críticos literários, escritores, políticos. O autor chega a citar nomes importantes da época: Olavo Bilac, Afrânio Peixoto ${ }^{12}$ e José Carlos Macedo ${ }^{13 .}$ Mas a estada no novo mundo dura exatamente seis parágrafos.

12 Júlio Afrânio Peixoto (Lençóis, 17 de dezembro de 1876 — Rio de Janeiro, 12 de janeiro de 1947) foi um médico, político, professor, crítico literário, ensaísta, romancista e historiador brasileiro. Ocupou a cadeira 7 da Academia Brasileira de Letras, onde foi eleito em 7 de maio de 1910, e a cadeira 2 da Academia Brasileira de Filologia, da qual foi fundador. Como ensaísta escreveu importantes estudos sobre Camões, Castro Alves e Euclides da Cunha. Como médico, conheceu e estudou as ideias e teorias de Freud, levando-as para muitos de seus romances. (www.academia.org.br)

13 Político e historiador brasileiro nascido em São Paulo, capital paulista, que como industrial e diretor de múltiplas empresas, fez várias viagens de estudo à Europa e aos Estados Unidos (1911-1928) e no meio comercial e político desfrutou de grande prestígio em sua época. Descendente de tradicionais famílias fluminense e paulista, era filho do médico José Eduardo Macedo Soares e de Cândida Sodré Macedo Soares, foi educado na Escola Modelo Caetano de 
Após quatro anos de diplomacia Palidoff resolve voltar a sua terra natal, instalando-se novamente em sua casa em Lisboa.

Há no final deste capítulo uma descrição da personagem que nos é bastante peculiar, no tocante à semelhança que carrega com aquele que lhe deu origem biológica:

Fradique foi então designado para dirigir uma seção do Ministério dos Estrangeiros; mas Carlos Fradique não era diplomata português para ter residência permanente em Lisboa, com trabalho o Terreiro do Paço; não, Fradique Mendes era um homem para viver correndo, saltando ligeiro no mapa do mundo, de fronteira em fronteira, de Legação em Embaixada, de Continente em Ilha [...]. (Ibidem, pág. 48)

Na tentativa dessa modernização da figura de um Fradique, na obra de Vidal, não muita coisa muda, ou melhor, temos que este Fradique (filho) torna-se o espelho do pai, talvez não tão competente tanto para a escrita, nem tão competente tanto para a conquista (sendo ela de qualquer nível), já que Vidal nos apresenta um texto bastante curto e sem, de fato, qualidade literária.

Não tomamos contato com as impressões deste Fradique por suas próprias palavras, mas sim pela palavra de um narrador onisciente, que ao seu gosto delimita os pensamentos da personagem.

Aqui a falta do gênero epistolar faz com que essa carta reflexiva, criadora, com preocupação estética e crítica de Fradique Mendes caia por terra. Ter um narrador não autorizado literariamente, ao contrário de um narrador que se diz Eça de Queiroz, parece não dar potência a essa personagem (Palidoff).

Ian Watt afirma ser a epístola o gênero narrativo mais íntimo (por isso entramos de fato na intimidade do pai), coisa que o narrador e gênero escolhido não deixa acontecer com o filho.

A proposta aqui acreditamos que seja (re)evidenciar a importância da figura portuguesa

Campos e o de humanidades no Ginásio de São Paulo, bacharelando-se em ciências e letras (1901) e formando-se pela Faculdade de Direito de São Paulo (1905). Continuando no magistério, foi professor de Economia Política e Finanças no Curso Superior da Escola de Comércio Álvares Penteado, São Paulo, e diretor do Ginásio Macedo Soares. Foi presidente da Associação Comercial de São Paulo e nomeado chefe da Delegação do Brasil à Conferência do Departamento e à $16^{\mathrm{a}}$ Conferência Internacional do Trabalho (1932). Foi eleito deputado à Assembléia Nacional Constituinte (1933) e foi Ministro das Relações Exteriores (1934-1937) e Ministro da Justiça (1937) no governo constitucional do presidente Getúlio Vargas. Foi nomeado (1937) presidente do Instituto Brasileiro de Geografia e Estatística, tornando-se o responsável pela instalação e funcionamento desse órgão da administração federal. Eleito para a Academia Brasileira de Letras (1937) na sucessão de Vítor Viana, tomou posse no ano seguinte como quarto ocupante da Cadeira 12 e tornou-se membro (1939) do Instituto Histórico e Geográfico Brasileiro, no qual seria vice-presidente, presidente e presidente perpétuo. Foi interventor federal no Estado de São Paulo (1945-1947) e novamente Ministro das Relações Exteriores (1955-1958), no governo Juscelino Kubitschek. Foi membro de inúmeras instituições nacionais e estrangeiras, entre as quais a Academia Uruguaya de Letras, a Academia Argentina de Letras e a Academia das Ciências de Lisboa. $23^{\circ}$ Presidente da Academia Brasileira de Letras, exerceu o cargo por dois mandatos consecutivos (1942/1943). Publicou extensa obra, na qual se destacaram Falsos troféus de Ituzaingó, história diplomática (1920), O Brasil e a Sociedade das Nações, ensaio (1927), O Banco do Brasil, como Banco Central de emissão e redesconto, conferência (1929), Fronteiras do Brasil no regime colonial, tese (1939), Fontes da história da Igreja Católica no Brasil, história (1954), entre outras. Muitos dos seus livros foram traduzidos para o espanhol, francês, inglês, alemão e italiano e faleceu também em São Paulo, aos 84 anos. (www.academia.org.br) 
frente suas conquistas no planeta, rememorando feitos e tentando reencaixar essa nação em um lugar que nunca lhe foi destaque. Coerente certamente tratar do filho como espelho do pai, já que este com tanta maestria representou uma tentativa de inovação e poder feroz de crítica em um olhar lusitano.

Coerente, mas talvez não tão original (no sentido de diferença e pioneirismo). Acreditamos que nesse quesito a proposta agualusiana e venanciana são de fato mais felizes.

Mesmo sem originalidade, o filho de Fradique parece conhecer, como diplomata, os lugares que o pai pode conhecer como viajante, curioso, pesquisador, cultuador: Haia, Londres, Madrid, Paris etc.

$\mathrm{Na}$ narrativa, em um salto, como acontece em grande parte do documento, o narrador (capítulo VI) conta, de maneira bastante subjetiva, sobre a visão de Palidoff sobre a revolução de 1910 em Portugal ${ }^{14 .}$ O diplomata abandona seu trabalho e volta a sua terra para então poder verificar o que verdadeiramente acontecia.

Há uma característica nessa personagem, nesse curto capítulo, que nos aponta à atenção: sem dúvida que o Fradique pai tomaria para si a causa, certamente se colocaria frente à situação política de seu país, e daí teríamos uma de suas cartas ácidas sobre a condição econômica e política lusitanas, independente do regime, se monárquico ou republicano.

Palidoff, ao invés de, coerentemente, como até agora fazia, seguir os passos do pai, se abdica da opinião, da palavra. Recolhe-se para sua individualidade e fica recluso em seu palácio, orando em nome da Pátria, como se pedisse ajuda divina: "Recolheu-se então só com alguns criados indispensáveis, e como monge em seu mosteiro orou, rezou pela Pátria, que ele, com o seu espírito nobre, reto e previdente, antevira em descalabro moral e intelectual.” (Ibidem, pág. 51).

Um Fradique sebastianista se apresenta aqui. Aguardar que a ajuda venha de algum lugar que não seja o do agir. Um desejo mítico está em Palidoff. A abstinência parece ser mais cômoda para esta personagem que, direta ou indiretamente, representa a figura de seu pai

Mas certamente Fradique Mendes não estaria em semelhante situação. Desistir de um tema que lhe causa incômodo e insatisfação não fazia parte do dicionário do Fradique Mendes queirosiano.

Sem dúvida, ou uma certa imaturidade literária de Vidal, ou até mesmo a posição que este

\footnotetext{
${ }^{14}$ A Implantação da República Portuguesa foi o resultado de um golpe de estado organizado pelo Partido Republicano Português que, no dia 5 de outubro de 1910, destituiu a monarquia constitucional e implantou um regime republicano em Portugal. Após a relutância do exército em combater os cerca de dois mil soldados e marinheiros revoltosos entre 3 e 4 de outubro de 1910, a República foi proclamada às 9 horas da manhã do dia seguinte da varanda dos Paços do Concelho de Lisboa. Após a revolução, um governo provisório chefiado por Teófilo Braga dirigiu os destinos do país até à aprovação da Constituição de 1911 que deu início à Primeira República. Entre outras mudanças, com a implantação da república, foram substituídos os símbolos nacionais: o hino nacional e a bandeira. (PROENÇA, Maria Cândida. D. Manuel II: Colecção "Reis de Portugal". Lisboa: Círculo de Leitores, 2006.)
} 
defenderia frente a própria revolução republicana, faz com que haja uma ligeira quebra na coerência desse jogo fradiquiano. O leitor do Fradique queirosiano talvez tenha vontade de, como pai, puxar as orelhas do filho e fazê-lo tomar partido.

Vidal coloca essa personagem em um grau de apatia social tão elevado que termina o capítulo afirmando que Palidoff "Deixou a política e durante anos não pensou em se envolver de novo em contendas difíceis como as que já experimentara" (Ibidem, pág. 52).

Acreditamos que se contrapusermos duas trajetórias específicas, a de Vidal e a de Agualusa, teríamos certamente um jogo de contrário. O que aparentemente representaria uma total incoerência na construção de um Fradique extremamente engajado e de um descendente deste completamente apático e imóvel.

Guardando suas devidas proporções (a do engajamento angolano para desmitificar a África e a da narrativa despretensiosa de Vital) temos uma quebra no jogo, uma penalidade que, aqui, custa mais a Vidal do que a Agualusa.

O capítulo número VII começa realmente a nos trazer algo que sobrepõe toda essa narrativa despretensiosa. $\mathrm{O}$ autor gera expectativa quando Palidoff (neste capítulo propositadamente tratado de Fradique) começa a vasculhar e descobrir o que havia dentro da famigerada arca de seu pai.

Faz referência (até mesmo como nota de rodapé) às origens fradiquianas tratadas no livro de Eça de Queiroz. Tenta, de maneira até original, criar vínculos (regra de um jogo narrativo) entre uma mania de Palidoff com a mesma mania de sua bisavó, colecionar objetos antigos.

De fato a ideia do passado e da coleção permeia toda a narrativa em que Fradique possa aparecer. Palidoff tem como posse uma coleção de objetos em seu museu, tudo aquilo que possa representar culturas singulares da terra. Parece materializar aquilo que seu pai pode ter (e com maior força) por meio de suas experiências de viagem.

Palidoff materializa suas experiências em objetos para seu museu, enquanto seu pai as coloca por meio das palavras, em suas cartas. Palidoff parece se constituir de objetos do passado, desde aqueles, como dito, de seu museu, como aqueles que eram pertencentes só seu pai, que os colocara na incrível arca.

Havia, de fato, uma ligação bastante particular entre pai e filho, isso o autor em vários momentos deixa claro. Uma admiração e um mistério rodeiam a figura de Fradique Mendes: "Lembrava-se do mistério em encobria o pai, Fradique Mendes, a quem só conhecera pelos retratos, mas a quem entrevia o espírito, as ideias, os amores, os ideais, a intimidade, pelo que nesse cofre velho, muito velho, se encerrava; [...]. (Ibidem, pág. 58).

Trata-se aqui não somente de uma admiração de pai pra filho, há um reconhecimento de que o pai representava sim um homem novo, de importância sociocultural para Lisboa. Como se Palidoff pudesse colocar o próprio pai como objeto histórico de seu museu. O pai fazia de fato parte 
de sua coleção.

O conteúdo do cofre é mantido em expectativa durante grande parte da narrativa, ou melhor, seu conteúdo parece se mostrar gradualmente, em fotos, lembranças, documentos. No capítulo XVIII há uma descrição do conteúdo desse cofre que nos chama a atenção, quando a mãe de Palidoff, no que parece ser seu leito de morte, entrega ao filho as chaves do cofre. É um momento bastante dramático da narrativa de Vidal, que parece entender esse momento como epifania do capítulo e até certo ponto da obra em si:

Meu filho, ali está o que teu pai me legou pedindo-me que tornasse desconhecido o seu recheio, até, quanto possível, da profanação da máquina da imprensa, dos olhares comerciais dos editores e das vistas espertas, ambiciosas, maldizentes dos críticos. Se prometes nunca deixares que outrém, que tu não sejas, veja o que o cofre contém; não quero dizer que não possas falar acerca deste recheio; podes, muitas vezes tu ouvirás dizer: $\mathrm{O}$ cofre encerra isto não é verdade? $\mathrm{E}$ tu rirás mas nunca dirás que sim nem que não; no entanto, se alguém que tu achares que o merece saber to perguntar; tu dizes mesmo o que pensas que ele contém, tu podeslhe dar um esclarecimento, mas sem que esse alguém veja o recheio, podes fazê-lo, que não ofenderás a nobre alma de teu pai. Se garantes que assim procederás ele será teu a partir de hoje, pois sinto que a minha vida do termo se avizinha. (Ibidem, pág. 58)

Uma áurea cerca esse cofre na narrativa de Vidal. Há algo que sobre Fradique não se deve saber. Em verdade toda a narrativa fradiquiana torna-se secreta (mote usado por Agualusa e também por Venâncio). E o secreto já surge no próprio gênero da fração queirosiana, como dito, cartas são secretas, endereçadas, só dizem respeito a aquele que escreve e a aquele que recebe, há nela, segundo Watt, uma marca de confidencialidade e intimismo extremos.

A fala da mãe de Fradique (filho) é definitivamente bastante coerente com aquilo que nosso Fradique Mendes eciano argumentaria, corroborando com o jogo estabelecido. De fato, e partes da obra queirosiana aqui trabalhadas provam: Fradique Mendes não queria que seus pensamentos fossem parar nas mãos de aproveitadores, principalmente de uma imprensa aproveitadora (como em carta ao amigo Bento de S. - XV). Se Fradique quisesse tornar seus pensamentos públicos não escreveria cartas, mas sim colunas de jornal ou livros de filosofia e política.

Todas as narrativas fradiquianas se enquadram em uma regra fundamental desse jogo, nunca esgotar essa personagem, sempre há algo a ser descoberto sobre o homem do século. O narrador de A Correspondência deixa o mote da arca, que é trabalhada por Vidal, que é retomada de certa maneira por Agualusa, juntando-se as cartas de Ana Olímpia (outro mote, outro percurso) e finda (dentro da nossa proposta) com a amarração de um romance ensaísta sobre toda essa trajetória fradiquiana, que ainda inesgotável (vide as obras de Joaquim Francisco Coelho e "A autobiografia de Fradique Mendes", composta à várias mãos) traz mais um elemento que impulsiona a narrativa, 
os Esquemas de Fradique (espólio secreto do espião Fradique Mendes).

No capítulo IX, o narrador nos conta sobre a visita de Antônio Sardinha ${ }^{15}$ ao palácio de Palidoff. Um renomado ensaísta lusitano parece entrar em contato com a arca do século XV: "Tu tens isto aqui?! Isto é a 'Vala Comum'... de teu pai - volveu Sardinha atônito.” (Ibidem, pág. 64). Capítulo este chave para a obra de Vidal, pois é nesse momento que Palidoff revela ao "Representante do Integralismo lusitano" que o autor de Lapidárias seria também o mestre da contra revolução.

Parece que Fradique Mendes passa aqui a ser mais uma vez representante de algo. É escolhido por um narrador, assim como o narrador queirosiano, como estandarte de um processo político-social: “- Pois bem: Tu, Antônio Sardinha, acertaste ao chamar a meu Pai, que Deus guarde, mestre da Contra-Revolução!” (Ibidem, pág. 65). É aqui usado por Vidal para fortalecer sua posição integralista, já que o Portugal que retrata passava por turbulências políticas. E assim, dentro ainda daquela linha do jogo, ele será apropriado por outros. Tornando-se objeto da defesa de ideias destes.

Assim como Fradique Mendes é recrutado por Eça, Palidoff é também soldado na guerra política discutida pelo autor. De um lado a ação da primeira república portuguesa ${ }^{16}$, do outro integralistas apáticos e trancafiados em seus palácios de um reino imaginário. Palidoff é sem dúvida o espelho desse segundo time, pois se abstém do mundo que o cerca e vive monarquicamente em seu palácio, onde também recebe seus iguais, deixando da porta pra fora toda e qualquer discussão sobre política e sociedade: “A vida externa Fradique só a sabia através duma ou doutra notícia de maior vulto e porque ouvia o som e o barulho das revoluções.” (Ibidem, pág. 71).

Enquanto o autor de Lapidárias definitivamente se alimentava do mundo em que vivia, fazia parte dele e com ele interagia, por uma questão de sobrevivência e necessidade, seu filho, ao contrário, se fecha dentro de um mundo imaginário (como aquele que espera, estático, a volta de um D. Sebastião) e particular, rememorando as glórias de monarquias passadas e agora, cada vez mais, em desuso: “[...] mas desabituara-se de sair ou, quando o fazia, era de carro, de modo que não só passava desapercebido ele ao mundo, como o mundo não se orgulhava com um simples relance do seu olhar claro" (Ibidem, pág. 71).

\footnotetext{
${ }^{15}$ António Maria de Sousa Sardinha (Monforte, 9 de Setembro de 1887 — Elvas, 10 de Janeiro de 1925) foi um político e poeta português. Destacou-se como ensaísta e polemista, produzindo uma obra que se afirmou como a principal referência doutrinária do Integralismo Lusitano. A sua defesa de uma monarquia tradicional, orgânica, antiparlamentar serviu de inspiração a uma influente corrente do pensamento político português da primeira metade do século XX. Apesar de ter falecido prematuramente, conseguiu afirmar-se como referência incontornável para os monárquicos que recusaram condescender com o salazarismo. (http://pt.wikipedia.org/wiki/Ant\%C3\%B3nio_Sardinha)

${ }^{16}$ A Primeira República Portuguesa (também referida como República parlamentar) e cujo nome oficial era República Democrática Portuguesa, foi o sistema político que sucedeu ao Governo Provisório de Teófilo Braga, de 1910 a 1926. Instável devido a divergências internas entre os mesmos republicanos que originaram a revolução de 5 de Outubro de 1910, neste período de 16 anos houve sete Parlamentos, oito Presidentes da República e 45 governos. Pródiga em convulsões sociais e crimes públicos e políticos(muitos deles "encobertos"pela maçonaria da época,e pela carbonária. (http://pt.wikipedia.org/wiki/Primeira_Rep\%C3\%BAblica_Portuguesa )
} 
Há então, se analisarmos o jogo dos autores com os quais nos propomos a trabalhar, um pêndulo em relação à aproximação deste "Fradique" com o mundo e é também pendular a proposta da crítica política e social destes personagens. No heterônimo há uma aproximação exagerada entre os elementos homem - Fradique - e mundo, em um caráter empírico, também crítico politica e socialmente.

Com o narrador de Vidal há na figura do filho esse distanciamento, esse isolamento dentro de uma suposta inadequação homem - Palidoff - mundo, mas há nessa negação uma crítica ao regime político da primeira república. Palidoff é aquele que representa mais fortemente o caráter mítico e socialmente apático lusitano. Sobre esse mito aponta o autor de Os Esquemas de Fradique Mendes, em entrevista:

Digamos que as descobertas portuguesas já foram acompanhadas de narrativas. O sebastianismo é também uma narrativa ideológica, que os portugueses dos séculos XVI e XVII contam a si próprios pra se aguentarem nas adversidades, e no fundo pra não se frustrarem, pra conservarem até um pouco de positividade de sua autoimagem. "Nós estamos em uma situação tremenda, sem nobreza, sem dinheiro, sem rei, mas Sebastião vai voltar". O Fradique é também uma narrativa ideológica. Digamos que há uma mensagem subliminar do Eça que é: "Nós, portugueses, somos uma desgraça, péssimos numa porção de coisas. Mas imaginemos que nós éramos um Fradique".

Palidoff então se aproximaria do polo mítico de que Venâncio fala, e mesmo Fradique habitando no universo do discurso ideológico, está em um outro polo, o da resistência crítica e ativa. Este que é tomado por Agualusa e é trabalhado de maneira exageradamente empírica, parece tomar aquele heterônimo e potencializá-lo em seu nível máximo, que trataremos a diante. Portanto esse jogo também se estrutura neste movimento pendular de intensidade na relação entre homem e mundo.

Além da clausura no início do capítulo XI, há nele informações que corroboram com a nossa tese de que Palidoff parece estar em outro polo no tocante à crítica política e social, ele se torna titular da Associação dos Arqueólogos Portugueses. Em um momento o leitor, quando o narrador fala que Palidoff anda por Portugal em busca de objetos que contem sobre culturas diversas, acha que o propósito dele é mostrar para o mundo suas descobertas, mas percebe, no decorrer da narrativa que esse homem é um estudioso do passado, o que corrobora com a imagem monárquica que se tem dele, e não exterioriza aquilo que estuda, guarda sua história para si, a história do seu país para si, e guarda-se em si mesmo: "Quem o visse em tais delongas [viagem a Pompeia], pensálo-ia como um nosso D. Sebastião, um pompeiano velho que, acordado do sono da morte, em êxtase profundo percorria as ruínas que lhe falavam o coração.” (Ibidem, pág. 74).

Quando resolve sair de seu palacete não perambula mais pelo seu país, vai ao restante da 
Europa, e um fato que nos chama a atenção ainda neste capítulo, é que resolve ir a um país de "tão viris tradições”, a Itália. Palidoff parece se resguardar na Itália, país católico de muita tradição artística. Sua visita à Pompeia mostra novamente o grau de resguardo que nutre Palidoff: "[...] e mais um dia percorreu silencioso, lento, absorto, as tristes ruinas duma e doutra cidade queimada, alheio ao resto do mundo.” (Ibidem, pág. 74).

Enquanto seu pai costumava arteiramente se instalar em Paris, cidade da inovação, da revolução e do crescimento: "Assim se afiliara em Paris a um clube revolucionário, As Pantheras de Batignolles, e frequentara as suas sessões, encolhido n'uma quinzena sórdida pregada com alfinetes, com a esperança de lá colher «a flor de alguma extravagancia instrutiva»” (QUEIROZ, 1923, pág. 26).

No final deste capítulo XI o narrador nos apresenta bem o seu "mestre da contra revolução", primeiramente tratando o movimento com bastante ironia: "No dia 28 de Maio de 1926, enquanto em Portugal o célebre movimento político estalava [...]”. Após isso afirma que Palidoff desde 1910 (momento da revolução) não falava sobre política e vivia enclausurado, somente neste contexto italiano, frente o Papa Pio XI, resolve conversar com sua santidade sobre os acontecimentos de Portugal, ocasião em que pede ao pontífice para que "orasse pela salvação de Portugal".

No capítulo XII nos é apresentado um fato que corrobora o jogo fradiquiano: o autor, ou narrador que entra em contato direto com a personagem, fortificando ainda mais todo o nosso discurso de aproximação dos Fradiques à realidade. Parece-nos que os narradores, na maioria das propostas de efabulação, tendem a entrar em contato físico com suas criações: o narrador Eça conhece pessoalmente Fradique Mendes, o narrador Vidal conhece Palidoff e o narradorpersonagem Martinho conhece os descendentes de Fradique Mendes.

Em um navio que "rodava pelo golfo", Palidoff encontra o que nos parece ser um velho amigo, o Dr. Perry Vidal! (curioso perceber que o autor somava na época da confecção da obra 16 anos, aqui este se coloca como Dr., uma ficção de si mesmo, o que é também bastante pertinente à proposta fradiquiana).

No âmbito narrativo acreditamos que tal característica possa pertencer a esse jogo, pois desde a criação de Fradique, a várias mãos, este foi colocado como personagem real da sociedade lisboeta. Logo, essa realidade, tendo em vista as propostas de crítica social e política de seus efabuladores, se torna bastante pertinente para fazer com que tais opiniões das personagens possam ter valor real, possam criticar um mundo real.

No capítulo XIV, vestido de Imperador Romano, Palidoff, quando volta de sua viagem para a Itália, promove entre poucos amigos (que compactuam com suas posições políticas) uma festa a fantasia, com todo o glamour das festas de grandes reinados. Todo esse ambiente serve sem dúvida para evidenciar a posição anti-republicana do autor e de sua criação, reafirmando o epíteto de 
Mestre da Contra Revolução.

No último capítulo da obra de Frederico Perry Vidal, Fradique Mendes (é tratado assim) após meses de clausura monástica - quando saia, ia sempre para países da Europa Ocidental, evitando andar entre os seus - somente em 1940 parece fazer as pazes com o seu lugar. Após várias viagens volta a Lisboa e mostra ao amigo Monsieur de Trevis tudo aquilo que Lisboa tem a oferecer no tocante aos seus monumentos e a cultura do país. Volta e no seu início de velhice pensa em se tornar frade.

Seria, a nosso ver, o fato de se tornar frade um reencontro com um Portugal medieval, original, católico e monárquico.

Ao cogitar um possível casamento, mesmo no início do inverno de sua vida, Fradique Mendes diz que só "quero uma portuguesa, tem de ser loira, alta, relativamente magra e de olhos claros; desde o Minho, com fatos de Viana, até o Algarve, a pisar o figo, procurei, não houve nada que me servisse!” (Ibidem, pág. 89). De fato aqui há uma ligação bastante peculiar com os gostos da fração fradiquiana tratada em Os Mistérios da Estrada de Sintra: quando diz que a mulher que o agradaria deveria ser como água de um lado, certamente esse mulher agradaria também ao filho, já que este é retratado, como trabalhamos aqui com extrema apatia:

Aquela água imóvel, azul, pálida, fria, pacífica, dá um extremo repouso à alma, uma necessidade de coisas justas, um hábito de recolhimento e de pensamento, um amor da modéstia e das coisas íntimas, o segredo de ser infinito sendo monótono, e a ciência de perdoar... Exijo, na mulher com quem casar, que tenha as unhas rosadas e polidas, e um ano de convivência com um lago! (QUEIROZ. 2008. pág. 199).

Mesmo que a experiência do jogo nos mostre posteriormente, dentro de uma outra perspectiva e proposta, que Fradique poderia certamente também se interessar por uma mulher como Ana Olímpia, esta que de fato não agradaria ao filho.

É neste último capítulo que Vidal nos retrata a morte de Carlos Fradique Patendorff, que expira suavemente, enquanto "ao lado um sacerdote que pediu fosse chamado para ouvir de confissão, reza os salmos e os sinos das igrejas dobram a finados" (VIDAL, 1950, pág. 91). Morrem em Portugal. Morre no dia de "Fiéis Defuntos" (finados).

A última informação da obra é de fato a mais importante do capítulo e quiça da obra, a partir do momento em que se criou, em seu início, e expectativa do conteúdo do cofre do Século XV: "Só o cofre do Século XV, a "Vala Comum" paterna, estava vazia; um criado disse que o vira, na véspera, com o cofre espanhol do século XV, junto ao fogo, a queimar o seu recheio" (Ibidem, pág. 92).

Não fora revelado enfim o recheio do cofre. E nos parece que este mote ganha fim quando 
nos é dada a informação de que tudo o que havia ali fora carbonizado. Para os efabuladores isso poderia parecer o fim ou a impossibilidade de uma continuação, tanto com o próprio Fradique ou até mesmo com alguns de seus descendentes (Palidoff não teve filhos, e era também filho único, até aqui). Mas tudo isso não foi problema para Fernando Venâncio, que consegue articular uma filha para Palidoff (Leonor) e ainda fazer com que parte desse espólio tivesse sido salvo (3.1).

O jogo não terminaria aqui, em uma obra que nos pareceu mal acabada, mal elaborada e rápida para se tratar de um descendente de pessoa tão complexa. Parece que a pressa fez com que Vidal passasse rapidamente por momentos da vida desse personagem que, ao olhar de um narrador onisciente, poderiam ter sido mais bem exploradas. Lacunas que serão preenchidas por outro efabulador.

\section{2 - ÁFRICA: A EXPERIÊNCIA CONTADA}

A obra de Eduardo Agualusa, Nação Crioula, é, dentre as do escopo, a que mais tem uma preocupação didática, ou seja, a que mais carrega em si a intencionalidade de desmitificar uma trajetória histórica escrita há séculos somente pelo olhar do colonizador. A África aqui desenhada é banhada de sangue e de lirismo, diferente do lugar comum "lugar onde habitam feras que precisam ser domesticadas", ou pior, "civilizadas".

E literatura do século XIX, e até mesmo a queirosiana, o que aqui nos interessa, tratou o negro de maneira estereotipada; como aquele que deveria ser civilizado pela verdadeira humanidade. Há uma passagem de A Correspondência em que o narrador (em sua primeira parte) explora a imagem de um negro - o negro de Seneh. Tratava-se de um garçom do restaurante em que Eça esporadicamente se encontrava com seu amigo, Fradique Mendes. Deve-se atentar ao tratamento dado à personagem:

Terminei por perguntar ao negro de Seneh que servia o macarrão. O selvagem escancarou um riso de faiscante alvura no ébano do carão redondo, e, através da mesa, grunhiu com respeito: - Cé-le-dieu... Justos céus! Le Dieu! Intentaria o negro afirmar que aquele homem de barbas encaracoladas era um Deus! (...) O que eu tomara por uma presença divina significava apenas - c'est le deux! Gautier no hotel ocupava o quarto número dois. E, para o bárbaro, o plástico mestre do Romantismo era apenas - o dois. (QUEIROZ. 1946. págs. 40 e 46)

Uma nação só vive porque pensa. Cogitat ergo est. A Força e a riqueza não bastam para provar que uma nação vive duma vida que mereça se glorificada na História como rijos músculos num corpo e ouro farto numa bolsa não bastam para que um homem honre em si a humanidade. Um reino de África, com guerreiros incontáveis nas suas aringas e incontáveis diamantes nas suas colinas será sempre uma terra bravia e morta, que, para lucro da Civilização, os Civilizados pisam e retalham tão desassombradamente como se sangra a se corta a rez bruta para nutrir o animal 
pensante.(QUEIROZ. 1946. págs. 133)

Há nesse narrador de A Correspondência um tratamento um tanto quanto estereotipado sobre a África. Não se trata, pensar bem, na voz de Fradique Mendes, mas sim de um Eça que admira esse dândi, principalmente porque ele já viajou ao continente africano e ao ocidente.

Um homem esclarecido porque pode presenciar as mais variadas manifestações culturais, e assim entendê-las. "'Quem viaja tem muito o que contar', diz o povo, e com isso imagina o narrador como alguém que vem de longe" (BENJAMIN. 1996. pág. 198). O narrador dessa obra de Eça se coloca a todo o momento como grande admirador de Fradique, se utilizando de adjetivos que de certa maneira endeusam essa personalidade e acaba se menosprezando frente o "grande autor de Lapidárias".

Podemos entender que seus argumentos parecem perder força quando comparados aos de seu "amigo". Na primeira parte da obra, vemos que Fradique ganha palavra via narrador. E em um dos trechos do capítulo VII o narrador diz perguntar para Fradique sobre uma de suas viagens à África.

E há aqui um relato no mínimo desarticulador de todo o discurso de Eça-narrador. Em conversa com Fradique, este teria relatado um pouco sobre suas andanças pela região de Zambeze (atual região do Congo e da Zâmbia), principalmente sobre os cultos e cerimoniais religiosos.

No final da conversa, Fradique chega a uma conclusão que, a nosso ver, coloca em xeque principalmente o que o narrador afirma sobre civilidade e nacionalismo. Ou seja, até que ponto uma sociedade é civilizada?: “(...) na religião o que há de real, essencial, necessário e eterno é o Cerimonial e a Liturgia - e o que há de artificial, de suplementar, de dispensável, de transitório é a Teologia e a Moral” (Queiroz. 1946. pág. 122).

Em A Correspondência, um pouco diferente do que encontramos em Os Mistérios, temos um Fradique crítico da sociedade como ela se apresenta, presa em dogmas e regras sociais. A teologia e a moral são categorias inventadas pela sociedade civilizada a qual ele pertence. Parece que Fradique pretende alfinetar um processo de evolução social, como se em algum ponto desse processo tivéssemos sido essenciais, verdadeiros. E as regras sociais nos colocaram atrás de grades em que cada barra de aço é representada pela moral, pela classificação, pela segregação, pela ética cristã etc. Um discurso, portanto, que vai de encontro ao do narrador (civilizatório).

Ainda em A Correspondência, e praticamente na mesma discussão entre o narrador e o seu amigo sobre as aventuras na África, Eça parece instigar Fradique para que este escreva um livro sobre suas viagens à África (o que Agualusa faz). E o homem do século diz “- Pra que?... Não vi nada na África, que os outros não tivessem lá visto.” e ainda complementa: 
- Não! Não tenho sobre a África, nem sobre coisa alguma neste mundo, conclusões que por alterarem o curso do pensar contemporâneo valesse a pena registrar... Só podia apresentar uma série de impressões, de paisagens. E então pior! Porque o verbo humano, tal como falamos, é ainda impotente para encarnar a menos impressão intelectual ou reproduzir a simples forma dum arbusto... Eu não sei escrever! Ninguém sabe escrever! (QUEIROZ. 1946. pág. 123)

O que nos chama a atenção nesses trechos não é exatamente o autor não ter nada, ainda, para falar sobre a África, mas sim o fato de que Fradique aqui se coloca contra toda uma contemporaneidade, frente uma corrente de pensamento cientificista, que aflorava no final do século XIX, pois acredita que algo só seria digno de ser escrito, exteriorizado, eternizado se "alterasse o curso do pensar contemporâneo", é, certamente, o que sua correspondência secreta irá fazer, alterar a visão da história dita como verdade universal.

Irá desmitificar a visão sobre o continente africano. Serão suas "impressões" na correspondência secreta que farão com que esse observador astuto possa definitivamente ter o que falar sobre a África. E aqui é importante frisar que Fradique, nas cartas de Nação Crioula, produz documentos com um alto teor subjetivo, de impressões e principalmente empírico:

Fica muito claro, entretanto, que o olhar que observa a sociedade angolana, no final do século XIX é produzido fora desse tempo, pois que a visão crítica com que muitos fatos são descritos exibe o descompasso entre os fatos relatados e a interpretação deles feita pela personagem. A proximidade entre o pensamento do escritor e a visão da personagem sobressai, por isso em muitas das cartas. (FONSECA. 2001. pág. 257)

Agualusa escolheu a dedo a personagem Fradique Mendes - um português de causas, vanguardista, e descontente com o modo de pensar de seus contemporâneos - para fazer do discurso desse grande homem o seu.

Por mais que a visão crítica com que Fradique interprete Angola seja um olhar moderno, ela nada se distancia do potencial olhar daquele Fradique oitocentista. As cartas "encontradas" por Agualusa têm um caráter secreto, e essa personagem é, de certa maneira, enigmática, misteriosa.

Por conjectura poderia haver cartas escondidas. É o que, de fato, levanta Fernando Venâncio em seu romance (não só cartas, mas cadernos, álbuns, esquemas). Este efabulador propõe uma leitura como a desta dissertação, enxergar Fradique Mendes como único, uma personagem feita a várias mãos: (imprescindível a longa citação - Capítulo 3 - O neto da escrava)

Carlos Fradique Mendes - é de conhecimento público - partiu, em outubro de 1876, da capital de Angola para o Brasil, levando consigo a noiva, Ana Olímpia Vaz de Caminha, que contava então vinte e seis anos. (...) Foi por uma Ana Olímpia ainda casada que Fradique se enamorou. Achou-a deslumbrante, escreveria ele para Paris, a sua madrinha, Madame de Jouarre. Uma ausência do 
marido de Luanda permitira aos dois os primeiros prazeres da carne. (...) No nordeste brasileiro, na ilha de Cajaíba, que Fradique acabou por adquirir, mais ao seu engenho de açúcar, viria a nascer Sophia, a filha do mais universal dos portugueses e daquela que nunca foi rainha do Congo. (...) Tudo isso o descobriu José Eduardo Agualusa, que reuniu em "Nação Crioula" umas vinte e cinco cartas de Fradique desconhecidas. (...) Prometeu-me o Dr. Fradique (neto), quando me telefonou outro dia, mostrar-me um velho álbum que, nos anos quarenta, em viagem ao Brasil, desencantou nas sua propriedade nordestina. A conterem-se nele fotos de Sophia, não poderá ultrapassar os dez anos de idade. (...) Está ainda por desvendar até que ponto o casal Queiroz e o casal Fradique privaram, se é que sequer travaram relações. Carlos escreve, de Paris, em novembro de 1877 (Agualusa diz 1887, por óbvio engano), uma carta a José Maria, então ainda em Inglaterra. (...) Mais: não existe na correspondência do romancista (Eça) a mínima referência à mulher de Fradique. Parece-me importante sublinhá-lo. Eça, escrevendo, de Lisboa para Paris, a Emília, na primavera de 1890, numa altura em que - já falecido Fradique - decide dar a conhecer, em Portugal, o grande filho que o País perdera, mantém silêncio sobre Ana Olímpia.(...) Terá Eça querido poupar a mulher ao conhecimento das relações dum amigo tão íntimo com uma senhora negra, misto bizarro de princesa e escrava? (...). Aí está, suponho, o tipo de coisa que o dr. Cristiano Fradique deseja que eu investigue bem. (VENANCIO. 1999. Págs. 17-21)

O texto de Venâncio entraria como matéria selante em todo processo de efabulação fradiquiana. O jornalista Martinho em outros momentos da narrativa recorre às cartas publicadas por Agualusa, ou seja, podemos dizer que a obra Nação Crioula serve também de substrato para o documento ensaístico de Venâncio (não só este livro, mas também a própria Correspondência e a obra de Vidal).

Agualusa coloca definitiva e empiricamente Fradique Mendes, o grande homem de causas, na África. Lá este começa a viver fatos históricos importantes, o principal deles é a descoberta de toda a logística do tráfico negreiro. Além de vivenciar elementos culturais que vão fazer esse Fradique, ao longo da narrativa, se tornar mais sensível e até mesmo mais engajado sobre a questão dos negros.

Ciente que este homem pudesse vivenciar tais fatos se se envolvesse emocionalmente com alguém que fizesse parte desse universo, o narrador de Agualusa faz com que seu "herói" se apaixone por uma negra angolana, Ana Olímpia (que depois é levada em consideração por Venâncio):

Afastei-me atormentado pela certeza de que aquela iria ser uma das piores noites da minha vida. Não foi. No instante seguinte vi-a: a mulher mais bela do mundo! Dançava-se a rebita, moda do país que com singular harmonia combina a graça mundana da valsa e o ritmo selvagem dos batuques. O mestre de cerimônias, um oficial negro conhecido com Gingão, dirigia a dança numa língua misteriosa, que mais tarde me garantiram ser francês. Ao vê-la - à mulher mais bela do mundo logo naquele momento me reconciliei com a humanidade e os meus olhos se abriram com outro interesse para este país e as suas gentes. (AGUALUSA. 2000. pág. 23) 
Agualusa (re)cria um Fradique que se coloca como exemplo daquele Flâneur de quem falamos anteriormente, e corrobora principalmente com nossa afirmação de que esta personagem extrapola as fronteiras dos boulevards e das galerias de arte. Uma personagem que (de forma ativa, não é mero coadjuvante) é ator principal, e dele temos além de suas impressões, ações que mostram sua capacidade modificadora.

Um trecho de bastante peculiaridade, e que mostra o "homem do século" como agente, principalmente no tocante às grandes causas, encontra-se em uma carta direcionada à Eça de Queiroz em que escreve, do Brasil e sobre ele, que se "filiou" a uma sociedade secreta e abolicionista: “(...) liguei-me recentemente a uma sociedade secreta, antiescravista (chamamos-lhe a Sociedade do Cupim!), e parto com o objetivo de colher apoios para esta causa entre os governos e instituições da velha Europa" (AGUALUSA. 2000. pág. 101).

Essa empreitada abolicionista se torna ainda mais bem trabalhada narrativamente quando o leitor se faz conhecer sobre a ligação entre Fradique Mendes e José do Patrocínio, ativista político de grande importância, que se destacou como uma das figuras mais importantes dos movimentos abolicionista e republicano no país.

O narrador de Agualusa, então, e definitivamente, coloca essa personagem no front. Seguramente esse homem do século, que serviu de lança para que, no século XIX, Eça de Queiroz e seus camaradas criticassem a sociedade da conjuntura, também pode (e é) ser usado para que um autor do século XX e XXI faça o mesmo. Mostre por um olhar aguçado que a África é muito mais do que aquilo que, de acordo com o senso comum e olhar de menosprezo, a maioria acredita que é. Uma África rica e repleta de lirismo.

O livro de Agualusa traz em seu subtítulo "cartas secretas", que vieram à tona pelas mãos de Ana Olímpia, mulher que no final da obra aparece em carta para Eça de Queiroz explicando os motivos e as circunstâncias que a fizeram tornar públicas.

A palavra "secreta" aqui já nos traz, principalmente para o leitor de Eça, uma ideia de continuidade, pois estão aqui "as cartas escritas por Fradique que não eram de conhecimento público".

A segunda edição, que nos é tomada como pesquisa, apresenta um Prefácio curto de Hermano Vianna ${ }^{17 .}$ Nele, após contar sobre o sufoco de passar pela alfândega guineense, Vianna nos coloca um parágrafo chave para começarmos a entender a obra Nação Crioula:

Nação Crioula não prende o leitor apenas por sua história bem contada e assumidamente novelesca (tem enredo que poderia fazer sucesso na televisão, tanto

17 Colunista do jornal O Globo. 
quanto a Escrava Isaura). Seus méritos são mais complexos e, de alguma maneira, neo-pós-modernos. (AGUALUSA, 2004, pág.7)

Embora o texto de Agualusa não se estruture completamente como um romance, há nele um fio condutor que, mesmo em um livro composto por cartas, proporcionaria um entendimento romanesco e, até mesmo, como diz Vianna, uma adaptação para TV, comparando o texto e o enredo a obras clássicas da produção em romance e adaptação televisiva.

Vianna acerta ao perceber esse entendimento romanesco na obra de Agualusa, e também ao dizer que há aqui uma extrema complexidade, pois a leitura de Nação Crioula pode muito bem ser feita por dois tipos de leitores distintos: aquele que é admirador de novelas televisivas e não carrega em si um conhecimento literário, um leitor talvez mais raso de obras literárias (e essa leitura é possível exatamente pelas características que aponta Vianna); e o outro leitor é aquele que traz em si o conhecimento de, pelo menos, a obra A Correspondência de Fradique Mendes, que lerá Agualusa, sem dúvida, como continuidade daquela.

Difícil dizer qual dos dois teria uma leitura mais prazerosa ou proveitosa, acreditamos que ambos tirariam de Nação Crioula aquilo que ela pode oferecer, uns, entretenimento, outros a continuidade de um jogo (o que aqui nos é pertinente).

Vianna disserta ainda sobre o conceito de Atlântico Negro do sociólogo Paul Gilroy, que afirma ser:

[...] ao mesmo tempo um conceito e uma realidade: espaço de trocas de mercadorias, corpos e ideias, que coloca que xeque a busca de 'origens' e raízes das várias culturas afro-americanas, mostrando como todas elas foram produzidas, ao mesmo tempo, de um lado e do outro do oceano, ou melhor, no trânsito interoceânico. (Ibidem, pág. 7).

Agualusa sem dúvida se encaixa nisso, pois há na própria metáfora do navio a ideia da interligação cultural, ou seja, Portugal, Brasil e Angola só são o que são porque há elementos que os ligam e os constroem. Isso é evidenciado também pelas próprias origens das personagens, uma angolana, um português e como resultado uma brasileirinha. Um triângulo que metaforiza a mistura e a essência do que é ser ao mesmo tempo português, angolano e brasileiro, exatamente o que acontece com Fradique Mendes.

E porque Fradique Mendes para viver tudo isso? Porque ele é aquele que durante muito tempo representou a utopia do ser português. Porque com ele (além de tudo aquilo que traz na formação da personagem: a flanerie, o espírito da descoberta, o eruditismo e a capacidade narrativa) há sem dúvida a metáfora da quebra dessa utopia lusitana e também a prova de que a constituição do próprio ser lusitano só pode ser feita partindo de uma ideia de miscigenação, como assim 
também acontece em Angola e no Brasil. Aparentemente pode haver em Agualusa um caminho inverso ao de Eça, entretanto, uma leitura minuciosa faz com que percebamos que esses caminhos são os mesmos.

Eça mostra um português que reconhece sua terra, critica-a, mas só consegue fazer isso, ter a percepção daquele "ser português" quando está fora dela, e quando tem a possibilidade de observar o outro. Assim também acontece em Agualusa, somente após entrar em terras alheias pode perceber que há muito de Portugal em Angola, muito de Angola em Portugal, muito de Brasil em Angola, e muito de Angola no Brasil.

Essa ligação entre as essências desses vários lugares pode ser exemplificada quando Fradique reflete sobre o próprio conceito de civilização:

O centro da civilização, Paris? Sim, claro! Mas o que é civilização? Entre o cavaleiro melancólico que frequenta os salões da Madame de Jouarre, minha gentil madrinha, e o remoto canibal do Alto Amazonas, não existe séria divergência moral, apenas gastronômica. (Ibidem, pág. 117)

Busca aqui discutir a questão da civilização e aquilo que ela implica em seu processo de seleção social. Para ser um cavaleiro há um processo de canibalização, lembrando até mesmo o conceito de Próspero e Caliban, levantado por Benjamim. Parece Agualusa querer ferir essa dicotomia, querer mostrar que a diferença entre as essências daquilo que é ser colonizador e colonizado é de fato uma linha tênue e perigosamente frágil.

Não há, acreditamos, aqui em Nação Crioula, principalmente após as vivências fradiquianas, a manutenção de um estado Próspero e Caliban, pelo contrário, há a tentativa de quebra.

O "anarquista" Fradique Mendes continua sendo o "entre lugar", uma regra importante do jogo. Durante a obra de Eça ele transita por vários lugares do globo, não só transita, mas empiricamente sente cada lugar, cada povo, cada costume. Assim também é em Agualusa, que tenta metaforizar o "entre lugar" e ninguém melhor do que Fradique Mendes para metaforizar isso.

Uma produção que tende a demonstrar a mestiçagem de maneira empírica, como dito pelo resultado entre a angolana e o português, levado à tona com o nascimento de Sophia (sabedoria), brasileira. O próprio gênero da obra pode ser entendido como híbrido, pois há, assim como afirma Vianna, uma tonalidade romanesca, misturada a estrutura epistolar; mais, além da utilização (como desde o início, em Eça) da mistura entre personagens reais e ficcionais. Tudo tende à mistura em Fradique, e após Agualusa, tudo tende à mestiçagem:

As trocas constantes retratadas em Nação Crioula surgem então não como indícios de uma possível utopia nunca realizada, mas como uma espécie de uma realidade 
paralela, muitas vezes propositadamente ignorada, que liga, há séculos, as culturas do Brasil, de Angola e de Portugal, além de outros países de língua portuguesa. (Ibidem, pág. 8)

Em relação à estrutura do "romance" de Agualusa, ele é apresentado em 26 cartas (mais que as XVI da obra de Eça de Queiroz). Dez cartas endereçadas a madrinha e confidente Madame de Jouarre, dez para Ana Olímpia e seis para Eça de Queiroz. Por mais que seja um número maior de cartas, há um número menor de destinatários. Isso se deve, a nosso ver, pela proposta, pela intencionalidade de produção de cada texto.

Em Eça percebemos que há a predominância da crítica política, e dos costumes portugueses (preocupação da época), já em Agualusa há uma preocupação em manter um texto não fragmentário, ou seja, um enredo romanesco, logo, uma continuidade de destinatários levaria a uma também continuidade de enredo.

A primeira carta da obra é endereçada à Madame de Jouarre, de Maio de 1868, Como em um enredo romanesco, Agualusa inicia suas primeiras impressões sobre o lugar onde acaba de desembarcar: "Atirado para a praia, molhado e humilhado, logo ali me assaltou o sentimento inquietante de que havia deixado para trás o próprio mundo.” (Ibidem, pág. 11).

Há nas primeiras impressões de Fradique uma percepção preconceituosa frente Angola (a que metonimicamente se refere África). É como se tivesse pegado exatamente aquele Fradique queirosiano e "jogado" em uma malha exótica (em amplo sentido). O "homem do século" acostumado aos boulevards parisienses e as mais chiques livrarias estava agora sendo objeto de estudo de um autor angolano e sendo colocado em experiências que sequer imaginaria - como já disse com Queiroz, que não haveria nada de interessante em África que alguém já não teria visto.

É recebido em África pelo temido coronel Arcênio de Carpo, que de coronel legítimo nada tem. Este recebe Fradique Mendes como um príncipe (também seu filho Palidoff, em Vidal). Epíteto que carrega pelas efabulações, como príncipe, rei, mestre, deus.

Naquela terra sem leis e aparentemente confusa, Fradique Mendes figura como rei. Na realidade em qualquer ambiente Fradique Mendes figuraria como "celebridade".

Mesmo com grande sabedoria, já nas primeiras linhas da obra de Agualusa, Fradique Mendes passa a figurar com certa passividade frente aquilo que o chama a atenção, parece se apresentar com receio de tudo aquilo que não conhece. Além disso, mesmo figurando como homem importante, é apresentado a uma África que, no decorrer da obra, se mostra mística e singular, e tudo isso faz com que Fradique fique bastante impressionado com o que vê.

Já desde o início da primeira carta, José Eduardo Agualusa parece querer situar o leitor em relação a que África é essa em que decidiu dar a Fradique Mendes o prazer de conhecer. Há indicações sobre a economia e a cultura do lugar, como se apresentasse uma casa ao novo visitante, 
trazendo a metáfora da apresentação da casa de Arcénio de Carpo a Fradique Mendes:

A seguir mostrou-me o resto da casa, incluindo o quintal, largo e fundo, que está em parte ocupado com as habitações dos escravos e com armazéns cheios de marfim, de borracha e de cera. Presas aos altos muros veem-se cadeias de ferro e no centro do pátio um pelourinho que o coronel garante nunca ter utilizado. Ainda há pouco tempo, porém, este mesmo espaço servia para engordar negros trazidos do interior e em trânsito para o Brasil. (Ibidem, pág. 13)

Sem dúvida podemos afirmar que a casa do coronel representa a África retratada, escravista, exportadora de matéria-prima e escravos. Relata à madrinha, agora com experiência, aquilo que conhece na teoria: "Já compreendeu, que rida madrinha, como fez fortuna o senhor Arcénio de Carpo? Precisamente: comprando e vendendo a triste humanidade [...] 'contribuindo para o crescimento do Brasil"' (Ibidem, pág. 13).

Esta carta é esclarecedora também em relação à conjuntura política da época, pois há uma reflexão de Fradique sobre a condição escravista brasileira, a condição fornecedora da África e o dito embargo inglês contra esse processo. Fradique passa a entender de maneira mais profunda e real todo esse "esquema comercial” principalmente após conversas com Arcénio de Carpo: "Na forte lógica do senhor Arcénio condenar a escravatura é já dobrar a cabeça diante da arrogância inglesa”. (Ibidem, pág. 14)

Madame de Jouarre, que em Eça fora usada por Fradique como confidente e principalmente expectadora das andanças de Fradique pela Europa, aqui é, coerentemente, também usada para esse fim. As cartas que caracterizam a descrevem a África são de fato voltadas a esta destinatária, como não poderia ser diferente nesse jogo.

Também nesta primeira carta já podemos perceber o tom romanesco do texto de Agualusa, pois as ações são tratadas criando-se expectativas, com fala de personagens em um jogo que escapa às reflexões (prioritárias) das cartas fradiquianas em Eça: “[...] perguntou-lhe, sorrindo, se estava preparado a atuar contra aquela mesma embarcação: - Ainda esta noite, ou mais tardar amanhã, este navio vai largar de Luanda com destino ao nordeste do Brasil levando nos porões quatrocentos escravos." (Ibidem, pág. 14). Situação em que se cria uma expectativa de conflito entre Arcénio (comerciante de escravos) e o capitão do cruzeiro britânico Water-Witch.

Nesta primeira carta Fradique Mendes nos apresenta suas primeiras impressões sobre a África e inicia um percurso narrativo cronológico, acreditamos que as divisões das cartas podem até mesmo ser entendidas como capítulos de um romance. E, como dito, assim como em Eça, se utiliza de Madame de Jouarre para descrever novos lugares, como se esta o acompanhasse na viagem.

A segunda carta é também destinada à madrinha. De fato isso pode até mesmo provar essa tentativa de continuidade que se aproxima do gênero romanesco, haverá nesta nova carta a 
continuidade cronológica dos acontecimentos. Já que a proposta de Agualusa é contar uma experiência, se diferencia da proposta queirosiana, que parte para uma vertente reflexiva, com destinatários diversos e sem, aparentemente, uma continuidade cronológica.

Inicia a segunda carta à madrinha com menor estranhamento em relação à nova terra e, como não podia deixar de ser, apresenta-se já inserido na vida cotidiana dessa nova gente (já que tal característica é fundamental em Fradique, por isso também tenha sido escolhido para figurar o romance):

Ignoro, é verdade, o preço exato d ouro na bolsa de Londres, desconheço o destino de Livingstone e nem sequer consigo acompanhar as intrigas da corte. Em contra partida sei que os ratos assados continuam a vender-se muito bem nos mercados de Luanda, a quinze réis a dúzia, enfiados pela barriga em espetos de pau, e que tem havido distúrbios no Sumbe e no Congo. (Ibidem, pág. 15)

Se Agualusa tem por objetivo fazer com que o leitor possa ter contato com uma África essencial, ou seja, que o leitor possa entender como era a verdadeira dinâmica de uma Angola colonizada, e também sobre seus aspectos culturais e econômicos, sem dúvida acertou em cheio com a escolha de Fradique, pois promove um deslocamento do cânone (de Próspero) para a margem (Caliban).

Esse jogo é continuado e aqui há em Fradique evidenciada uma das suas principais característica, a sede pela descoberta, e a sua capacidade de se inserir em diferentes culturas, sentindo-as, contemplando-as e vivendo-as como se fosse o seu próprio ambiente. Não seria de fato possível mostrar uma África assim se nos fosse apresentada uma personagem que não tivesse exatamente essa capacidade e potencial e interação.

Além de ser pertinente a escolha é também corajosa no sentido de que Fradique representaria para o grupo do Casino um ideal português, o mesmo ideal que colonizou Angola, Moçambique, Guiné-Bissau, entre outras localidades na África.

Fradique mostra, do decorrer dessa carta, que a sociedade luandense, por mais que tenha suas singularidades (que no decorrer da obra preocupa-se em mostrar), é construída das mesmas intrigas sociais da metrópole. Parece no início tomar contato com a parcela angolana que se assemelha à sua terra, assim havendo de início uma maior e mais rápida identificação.

Como bom pesquisador, divide a sociedade angolana em extratos: 1. criminosos a cumprir pena de degredo. 2. degredados que após cumprirem a pena acharam por bem ficar, e 3. os filhos do país, mestiços e negros. E todo o trabalho da colônia está nas mãos de escravos.

Fradique faz, como em carta escrita por Eça, um comentário bastante peculiar, e típico fradiquiano, sobre algumas origens de palavras. Parece-nos que para um homem que lida com palavras (conhece-se Fradique por meio de sua palavra escrita) um estudo filológico, linguístico 
delas é bastante pertinente, o que corrobora o jogo fradiquiano:

[...] entendem a palavra trabalhar no seu sentido original, do latim tripaliare, ou seja, martirizar com o tripaliu (instrumento de tortura). Recordo a propósito que em inglês, slave, escravo, provém de slav, eslavo - porque os eslavos foram os primeiros escravos romanos. Também a palavra rabota, em russo, quer dizer trabalho, e tem como raiz rab, que significa escravo. (Ibidem, pág. 16)

Fradique, frente uma questão social bastante crítica não perde a oportunidade de colocar em prática a sua erudição, principalmente no que diz respeito às origens e constituição das línguas. Mostrar que o trabalho está intrínseca e fortemente ligado à formação das palavras em determinadas culturas é mostrar também que essa prática está ligada à cultura desses lugares. E é isso que Fradique Mendes faz, mostrar as relação não-natural do trabalho escravo com a evolução do homem, e sim algo praticado culturalmente.

Fradique Mendes é jogado sapientemente em um território tangido pelo preconceito e pelo sub julgo. É hóspede de Arcénio (comerciante de escravos) e ouve os discursos deste e de seu filho (que leva o mesmo nome). Há nesses discursos uma posição extremamente colonizadora frente os povos que ainda persistem com seus trabalhos de subsistência e de preservação cultural no interior de Angola.

Nas suas palavras os pretos do mato constituem grande obstáculo à rápida transformação de Angola num país moderno uma vez que não tem sequer uma ideia de Estado, recusam-se a falar português e permanecer cativos de toda a espécie de crenças e superstições. (Ibidem, pág. 17)

Acreditamos que aqui esteja uma das singularidades desse jogo fradiquiano. Agualusa se utiliza de uma personagem que representa a modernidade e a civilização, coloca-o de maneira nada sutil em uma sociedade para a qual essa civilização só fez criar mazelas e, além disso, proporciona a ele uma visualização privilegiada de todo esse processo. Ouve dizer que Angola não se moderniza por causa de negros que vivem suas vidas de maneira tribal, mas percebe que essa maneira pode ser de fato mais digna e justa do que todos os problemas causados por um processo forçado de modernização.

É como pegar uma arma e apontar para si mesmo. Fazer o homem colocar em xeque todo seu processo de civilização, tão evidenciado durante a segunda metade do século XIX. Faz com que se pergunte se todas as culturas (por mais tribal e diferenciada que seja) estão à mercê de um processo único de modernização (e colonização).

E é isso que Agualusa proporciona: uma análise de todo um processo de modernização que talvez não estivesse preparado para o grau de diferenciação que o continente africano apresentava. 
O próprio Fradique responde em carta à madrinha sua opinião sobre essa discussão que fora colocada acima: “Antes de forçar um Africano a trocar as peles de leopardo por uma casaca do Poole, eu calçar uma botinas do Malmstrom, seria melhor procurar compreender o mundo em que ele vive e sua filosofia." (Ibidem, pág. 17).

O poeta tem uma percepção bastante aguçada frente todos os olhares e discursos que tem contato. Da mesma maneira se coloca com firmeza frente opiniões preconceituosas, como se colocou ao filho de Arcénio.

E vai além: “Aquilo que os europeus desconhecem é porque não pode existir.” (Ibidem, pág. 17). Por isso Fradique Mendes, um europeu que descobre que aquilo que o europeu desconhece pode, deve e tem o direito de existir. Por mais que vá contra tudo aquilo que estes entendem como civilidade.

No final desta carta à madrinha, Fradique coloca em prática uma narrativa que demonstra, primeiro, o caráter romanesco da obra, segundo, o caráter pedagógico do texto e, por último, a importância em se evidenciar aquilo que é regional, que é tribal, que é essencial nas histórias da África. Conta uma fábula em que há um casamento entre uma luandense de família clássica e um enfermeiro de origem interiorana, ele é assassinado, e ela é obrigada a se casar com o assassino do marido, logo após acaba cometendo o assassinato deste.

Sem dúvida, para um Fradique que começa a descobrir novos horizontes e colocar em xeque a afirmação de que a humanidade deve se modernizar, finalizar uma carta à madrinha contando sobre uma lenda desse novo lugar mostra realmente um grau de interatividade bastante elevado.

E para evidenciar ainda mais o caráter narrativo da proposta cita Camilo e Zola: "O nosso feroz Camilo teria terminado aqui esta novela. Zola ainda antes, naquele cais onde primeiro correu o sangue.” (Ibidem, pág. 18).

Na terceira carta, ainda à Madame de Jouarre, do mesmo mês (junho), Fradique inicia dizendo que está reconciliado com a nação angolana, por isso conta sobre uma festa que presenciou, na casa do Governador. Em meio à "nobreza" angolana "quem quer que nesta cidade, tendo algum capital, saiba ler e escrever" (Ibidem, pág. 21) Fradique descreve à madrinha os mais variados tipos e, como em um salão da nobreza da metrópole, apresenta os mais variados seres "folclóricos" daquela sociedade.

Fala daquela que seria a mulher mais feia do mundo (a senhora Gabriela Santamarinha), e nos parece que começa a articular um baile de nobreza às avessas, já que essa mulher era "feia e tão satisfeita de o ser". Digna de ser comparada à descrição que Gregório de Matos Guerra faz a uma crioula, como cita Fradique: "Boca sacada com tal largura / que a dentadura / passeia por ali / desencalmada".

Tudo nessa sociedade angolana civilizada, por mais que se assemelhe à metrópole no que se 
refere às suas tramas e fuxicos - salvos tipos singulares - é carregada de excentricidade, o que a torna única. Só um Fradique observador como é (e também muitas vezes excêntrico - característica vista principalmente em sua aparição em Os Mistérios da Estrada de Sintra) poderia apresentar à madrinha essa nobreza virada de pernas para o ar.

Mesmo em um ambiente aparentemente moderno e urbano, Fradique Mendes é levado à sua primeira prova de fogo. É obrigado a fazer parte de um ritual iniciático (típico de sociedades tribais), ser apresentado ao "Abominável Monstro das Retretes" (Santamarinha) e não sucumbir. “[...] ser apresentado à senhora Gabriela Santamarinha é em Luanda quase um ritual iniciático. [...] Respire fundo e venha. Quando estivermos junto dela não respire.” (Ibidem, pág. 23).

Uma sociedade que pode ser vista como um misto daquilo que se entende como civilizado e daquilo que é tipicamente tribal. A mulher é praticamente uma figura mítica em carne viva, com a qual fica cara a cara o homem do século. A África para Fradique parece-nos se pintar como um monstro mítico, que ao mesmo tempo assusta e fascina.

Ao desvendar os mistérios de Gabriela, Fradique passa a não vê-la como monstro, mas sim como parte essencial daquele lugar mítico. "Ao vê-la - à mulher mais bela do mundo - logo naquele momento me reconciliei com a humanidade e os meus olhos se abriram com outro interesse para este país e as suas gentes" (Ibidem, pág. 23).

Somente após passar pela experiência de contato com esse ser mítico Fradique pode achar nela uma beleza inconstante. Diferente daquela que costumava observar. Há aqui uma metáfora, acreditamos, da proposta agualusiana, a quebra de um estereótipo africano, a conquista e a mostra daquilo que pode ser essencialmente angola e seus habitantes - não é o belo, nem o grotesco, é o natural.

E é, como em uma grande narrativa, nesse momento, em que Fradique é definitivamente apresentado à África, e por ela se apaixona, que toma seu primeiro contato com aquela que será, durante toda a obra agualusiana, o grande amor de sua vida.

Um elo entre ele e este lugar não podia deixar de ser representado pelo amor entre ele e filha de uma escrava (envolvida com todo o processo de exportação de escravos). Mas nela havia o sangue nobre, pois era filha de um príncipe congolês. Na figura dessa mulher já há quilo que metaforiza a própria África, pois ela é o contraste entre a escravidão e o poder. Fora filha de escrava, mas sobrevivia do tráfico negreiro. Era ela a antítese africana.

Tão complexa a figura de Ana Olímpia que Fradique se espanta quando a ouve "citar Kant e Confúcio, troçar das teses de Charles Darwin, comentar com inteligência e novidade a moderna lírica francesa" (Ibidem, pág. 24). Um berço que aparentemente não condiz com o que é hoje, o que seria para a nobreza europeia motivo de escárnio é aqui admiração, por se tratar exatamente de uma personagem que representa essa mistura entre o moderno e o tribal. 
Fradique, como homem de metrópole pergunta indignado: "'O que faz uma mulher como você num lugar como este?'. Ela sorriu, belíssima: - Este lugar é o meu país.” (Ibidem, pág. 25)

Após as densas descobertas deste episódio, Fradique se despede de sua madrinha com as seguintes palavras: "Seu afilhado quase africano". Essas palavras dão início a um processo de africanização pelo qual Fradique Mendes passa durante a obra de Agualusa.

A próxima carta é endereçada à Ana Olímpia, se na carta anterior, endereçada à madrinha, vemos o início de um processo de africanização fradiquiana, aqui há a introdução de uma personagem de passagem rápida, e também peculiar, quando Fradique fala sobre Luiz Gonzaga, que fora companheiro de república.

Parece-nos que este já se entregara ao ambiente africano, já passou por todo o processo que se inicia em Fradique Mendes. "Recordamos Coimbra, mais eu do que ele, que parece haver perdido o interesse por tudo quanto diga respeito ao velho Portugal. A espécie de clausura a céu aberto em que vive transformou-o num outro homem”. (Ibidem, pág. 28).

Na obra nos é clara a criação de uma dicotomia, a antítese velho versus novo. A África traz a metáfora do sol, da luz, do quente, enquanto Portugal traz a metáfora do cinza, do frio, do velho. Essa dicotomia é evidenciada na própria figura de Fradique, que se torna aqui um "novo homem", ou melhor, se não se torna um, potencializa essa ideia do "novo". Novas descobertas, novos amores, novas experiências. Até mesmo novas utopias.

Há nesta carta, ainda na figura de Luiz Gonzaga, um momento que mostra uma inversão dos valores: colonizado versus colonizador. "[...] e fico a vê-lo com a sensação de que este país o colonizou" (Ibidem, pág. 28). Toda relação entre o colonizado e o colonizador é baseada, em sua maioria, pela implicação da força, a injeção de uma cultura e a destruição (ou transformação) de outra. Está implícita nessa relação a violência.

Aqui o processo de colonização se estabelece, parece-nos, que de maneira passiva e até consensual. Parece-nos que essa "força de colonização" da cultura africana trabalha em um segundo plano, o do deslumbramento, não o da violência. Isso prova o fato de Fradique se ver aos poucos africanizado.

O exótico e singular se estabelece na África agualusiana. Somente aqui poderíamos observar um médico ter o objetivo de levar seu paciente a um feiticeiro.

Parece-nos que o quinto documento, endereçado ao escritor Eça de Queiroz, publicado nessas Correspondências Secretas, continua numa mesma perspectiva da carta anterior, ou seja, se antes há a figura excêntrica do médico adepto ao feitiço, aqui há a construção de outra personagem que reforça a ideia de que a África pode ser de fato um lugar mítico, onde a lenda, o conto popular estão de fato ligados à crença e ao cotidiano de seus habitantes.

Fradique conta a Eça sobre a figura de Padre Nicolau, figura excêntrica - a começar pela sua 
descrição física: “[...] é anão! A cabeça, presa a um minúsculo tronco de criança, parece enorme, muito maior que a de um homem normal" (Ibidem, pág. 33). Sua figura, ao contrário das narrativas em que a imponência física gera a condição de controle, pode parecer incoerente com o poder social que essa personagem tem: "Entretanto, emana dele tal autoridade, sobretudo quando fala, que ao seu lado poucas pessoas alcançam maior estatura. Áspero, rude, muitas vezes dogmático, o padre é, apesar disso, excelente conversador" (Ibidem, pág. 33).

O poder da palavra é mote nesta carta a Eça de Queiroz. De fato não há interlocutor mais pertinente. Fradique (Agualusa) apresenta a Eça, em um primeiro momento, uma África que este, em A Correspondência, dizia não haver nada de tão interessante que os outros já não tenham visto, depois acaba por discutir o poder da própria criação literária, mítica.

Conta ao amigo sobre os "milagres" feitos pelo padre: “'O senhor está curado', disse passando a mão direita pelo corpo de infeliz, 'levante-se e vá para casa'. Obedecendo a ordem [...] o caçador levantou-se e tomou o caminho da cidade, onde chegou já vivo” (Ibidem, pág. 32). Histórias que o poder da narrativa popular fazem se tornar verdade, torna-se lenda, mito, religião.

Semelhante processo pelo qual passa o texto literário quando se envolve a própria figura de Fradique Mendes, personagem que surge com um pé na realidade e outro na ficção, criado pela pena de um dos maiores escritores portugueses (guardando aqui a devida importância de outros na criação).

Tal força narrativa é mencionada, talvez ironicamente, o que faz parte desse jogo, tanto a ironia quanto a própria criação narrativa que brinca com a relação realidade x ficção: “[...] mas em contra partida fui testemunha de um episódio a partir do qual V., em rápidas linhas, poderia com facilidade criar literatura. Eu, mais pobremente, o caso conto como o caso aconteceu:" (Ibidem, pág. 31).

Eça incontestavelmente é um autor canônico que carrega em si todas as qualidades para uma plausível criação literária. Mas aqui temos um Fradique pelas mãos de Agualusa que, por sua vez, é tão perspicaz, feroz, excêntrico (regras do jogo) quanto a fração eciana.

Se o Fradique de Eça conta e descreve suas experiências com maestria, o de Agualusa também o faz trazendo à tona aquilo que teoricamente teria escapado a Eça. Logo, a negação de não saber contar provoca aquele que iniciou a linha de criação fradiquiana. Ironicamente Agualusa estabelece um parâmetro para as criações (mesmo que involuntariamente), transferindo ao Fradique (levando em consideração todas as efabulações) aquela técnica e aquele crivo narrativo do primeiro, que surge pelas mãos do cânone.

Após discutir a criação do mito com o amigo Eça de Queiroz, Fradique de dirige novamente à Madame de Jouarre. Para ela disserta sobre as diferenças entre as negras africanas e as brancas europeias. Conta sobre casos em que mulheres negras dilaceraram corações brancos: "Há no sangue 
das negras um princípio acre que primeiro cativa a depois atrofia e destrói o coração dos homens brancos" (Ibidem, pág. 35).

Conta para a madrinha que, em ceia com Arcênio de Carpo, refletiu sobre tais palavras: “ - A mulher europeia [...] está para a africana como o frango cozido em água e sal está para o churrasco. Falta-lhe a cor, o perfume, o sabor e o calor. Falta-lhe o gindunguzinho, meu caro. Resumindo, falta-lhe a alma.” (Ibidem, pág. 36/7).

A mulher africana é conduzida a um grau de sensualidade bastante elevado, em contra posição a mulher branca, que longe é vista como ideal de beleza, aqui é subjugada.

Muito coerente haver uma carta em que se discute a conquista e a sensualidade femininas, mais coerente ainda é haver essa discussão em uma carta endereçada a Madame de Jouarre. Toda essa temática sobre sensualidade e conquista mostrada na introdução da carta tem como finalidade chegar a algo maior para Fradique, falar sobre Ana Olímpia. Sua confidente Madame de Jouarre depois de ouvir sobre todas as virtudes, até mesmo sexuais, da mulher negra, passará, a partir desse momento, a ter conhecimento do grande amor de Fradique.

Passa a conhecer também a história dessa mulher. Fradique conta sobre seu casamento com Victorino Vaz de Caminha, personagem que também destoa do trivial, traz em si a contraditoriedade (elemento que parece permear esse universo africano): dono de três navios negreiros, que receberam os nomes de Liberdade, Igualdade, Fraternidade, anarquista que assinou panfletos anticlericais e depois se casou na igreja. Casou-se com Ana Olímpia, que fora sua escrava e contava com somente quatorze anos quando de suas núpcias.

Quando percebeu que a morte estava próxima, Caminha viveu para Ana Olímpia, "Mandou vir de Paris um professor de francês, o que durante os doze meses que permaneceu em Luanda engravidou doze escravas" (Ibidem, pág. 37). Também trouxe professor de música:

"Victorino Vaz da Caminha preocupou-se em particular com a educação política, filosófica e literária da jovem esposa. Discutiu com ela Proudhom, Mikhail Aleksandrovich Bakunin e depois deu-lhe a ler, em francês, o inevitável Hugo, o terrível Baudelaire, o genial Flaubert, o nosso velho e querido Gautier, o vasto e desordenado Balzac, o mesmo e intolerável Lamartine, os Taine, Goncourt e Michelet. A valente criança leu-os a todos, sobreviveu e fez-se uma mulher lúcida, forte e com opiniões, enfim, uma mulher como é difícil encontrar um homem." (Ibidem, pág. 39).

Ana Olímpia é então a composição daquilo que para Fradique seria uma mulher perfeita, ou seja, traz todos os atributos que a mulher negra pode oferecer (praticamente enumerados no início da carta) mais um grau de intelectualidade bastante elevado. Seria um misto entre uma intelectualidade europeia e a sensualidade (cor, perfume, alma) de uma negra. Podemos nos arriscar a dizer que Ana Olímpia poderia bem ser uma versão feminina moderna de um Fradique Mendes. 
[...] Ana Olímpia não discute apenas a evolução das espécies ou os últimos acontecimentos na Europa como se sempre tivesse vivido no centro do mundo estuda com idêntico interesse o passado do seu próprio povo, recolhe lendas e provérbios da variadas nações de Angola, e prepara mesmo um dicionário de português-quimbundu. Uma vez por ano viaja até as províncias do norte, às terras que foram do seu pai, e os sobas e seus macotas aconselham-se com ela. (Ibidem, pág. 39)

No palacete que herdou de seu marido, junta as mais diferentes etnias de Angola, nas mais diversas personalidades: "Fui a uma dessas reuniões e admirei-me ao encontrar ali brancos, negros e baços, todos unidos no mesmo amor por Angola.” (Ibidem, pág. 39). Podemos perceber que, diferentemente de seu marido, Ana Olímpia coloca em prática em suas relações a Liberdade, Igualdade e Fraternidade.

Esta carta, enfim, é trabalhada para que a confidente amorosa de Fradique (e os leitores) fique sabendo sobre a origem e a formação da mulher que conseguiu desestruturar, de certa maneira, um homem que era, até o momento, a metáfora do equilíbrio e da razão.

À Ana Olímpia é direcionada a sétima carta de Nação Crioula. Vemos que se trata de uma carta com um cunho bastante romântico. Acreditamos que mais do que todas as endereçadas a Clara, em A Correspondência. "Hoje sei que estava à tua procura. Sei que és o meu destino, a minha pátria, a minha igreja" (Ibidem, pág. 44). De certo modo o clima e estrutura romanesca da obra agualusiana pede cenas de caráter mais romântico, diferentemente do caráter mais fragmentário da obra de Eça. O vocativo utilizado é "Minha doce Princesa" e a despedida é um solitário "teu". Solitário porque toda a carta é construída com o objetivo de mostrar a saudade que o remetente sente de sua amada.

O documento é redigido em Paris, e para completar um ambiente de desolação, trata-se de dezembro, inverno. O que leva Fradique a montar uma metáfora bastante pertinente principalmente com um elemento que traria aquilo que representaria a África, na figura de Ana Olímpia: "E há-de ainda ser Dezembro depois de terminar o mês, e a seguir virá Dezembro e o Inverno, e novamente Dezembro e sempre assim, até que de novo eu retorne à Estação do Sol, que é com toda a parte todo o instante que o teu olhar ilumina.” (Ibidem, pág. 43).

O Sol de fato é a figura da África, e o Inverno é de fato a figura da solidão e da Europa. Parece-nos que toda a "civilização" começa a perder terreno frente um sentimento de amor àquilo que representa não só uma mulher, mas tudo aquilo que a envolve: uma pátria, um povo, costumes, uma personalidade exótica, excentricidades. De fato isso é comprovado quando Fradique começa a encaixar em uma situação típica europeia uma entidade da crença africana: Muene-Zambi-diaMenha (a divindade das águas), como se ela pudesse influenciar no cotidiano europeu (agora para 
Fradique pode). Essa divindade traz o desequilíbrio: “[...] e como uma imensa jiboia enfurecida [...] o rio saltou sobre a cidade atropelando as pontes, arrancando árvores, atacando casas, prédios e monumentos nacionais" (Ibidem, pág., 44).

Podemos entender aqui sim uma transposição de culturas, ou melhor, até mesmo uma sobreposição cultural, mas em um sentido contrário. Há uma cultura do colono que se sobressai e interfere no estado das coisas de seu colonizador, pelo menos nas impressões, mesmo que românticas, de Fradique Mendes.

Seis meses depois Fradique envia outra carta a Ana Olímpia (8. carta), bastante curta, em que usa como vocativo "meu amor". Este documento nos dá a entender que Ana Olímpia desagradou Fradique na resposta da carta n. 7. Há menção de que "para uma segunda questão" não haveria resposta. Esta tática de escrita é bastante semelhante à usada por Eça na composição de $A$ Correspondência, quando se faz entender, ou com trechos, ou com uma reflexão, aquilo que o interlocutor de Fradique teria dito (a voz do outro).

Aqui há um enigma quanto essa "segunda questão", mas percebemos que o tom da resposta de Ana Olímpia não fora muito agradável para Fradique. Há aqui um aparente desgaste dessa pseudo-relação - um conflito romanesco. Na sequência, uma carta ainda menor endereçada a Ana Olímpia, agora com o vocativo de "Preciosa amiga". Nela há uma resposta a uma carta em que Ana supostamente conta que está passando por sérias dificuldades (não comentadas por Fradique - para que não perca o mote do mistério). Parece fria e sem aquele sentimento de outrora (de quatro anos atrás, carta n. 7). Coloca-se preocupado com a situação de, agora, sua preciosa amiga. Podemos dizer que há um gradual tanto na perda, ou enfraquecimento desse sentimento amoroso, como na própria forma do texto, perde-se o sentimento na mesma proporção que se perdem as palavras. Quanto menor o romantismo, menor os predicados, menores são as cartas.

As próximas cinco cartas são endereçadas a Madame de Jouarre. Parece-nos que essa estrutura romanesca da qual Agualusa se faz valer tende, e pede, coerentemente, que ele estruture uma cronologia para que sua madrinha (burguesa) leia, como se realmente estivesse lendo um romance.

O desenrolar romanesco aparece nessa carta de n. 9 para a madrinha: “Ana Olímpia [...] foi entregue como escrava a um aventureiro recém-chegado do Brasil!” (Ibidem, pág.51) - já que era escrava que nunca recebera carta de alforria, por Vaz de Caminha achar desnecessário.

Fradique conta sobre sua partida para Luanda, a fim de desenrolar tais acontecimentos. E durante todo esse bloco de cartas escreve sobre suas decisões, sua relação com Ana Olímpia como se elas fossem representantes de um momento epifânico de um romance, ou um capítulo decisivo.

Na segunda carta desse bloco (carta geral n. 11) conta sobre como encontrou a situação em Luanda “Ana Olímpia continua em Luanda [...] Jesuíno vendeu-a (ou a alugou) a Gabriela 
Santamarinha (aquela que tinha por prazer judiar de escravos)".

Junto com Arcénio de Carpo prepara-se para uma guerra, aos moldes épicos (movimento armamentista, expectativa de guerra, confronto) Fradique Mendes se vê frente seu destino, sem controle de seu presente, com sentimentos aflorados e agindo de maneira quase inconsequente. Parece escapar de sua parte racional e reflexiva da qual principalmente Eça e Vidal se fazem valer.

Arquiteta-se ainda na carta n. 11 um plano para matar Jesuíno (morte por emboscada na caçada de jacarés). Antes dessa caçada Fradique oscila e entra novamente nos "eixos da reflexão". Antes onde dizia "[...] com o firme propósito de abater esse canalha a tiro (não é uma figura de estilo)" (Ibidem, pág. 52), agora parece centrar-se em seu racionalismo: “[...] que a ideia que me parecia estúpida, tão ingênua e tão estúpida que era até capaz de resultar, mas que não contasse comigo" (Ibidem, pág. 55). Oscila entre a emoção e a razão, até que finaliza sua carta: “[...] um touriste de fato e linho branco em busca de exotismo e emoções fortes” (Ibidem, pág. 56).

Esse conjunto de cartas monta uma importante trajetória para o romance - Lisboa, Luanda, Novo Redondo, Olinda. Nela há aquilo que se propõe Agualusa, discutir o entre lugar, há aqui o triângulo (Europa, África, Brasil). E sem dúvida o momento alto do texto, pois há o maior número de ações contínuas, o que não apresenta Eça, e muito menos Vidal. Enquanto estes estabelecem reflexões sobre lugares que parecem distintos e separados, Agualusa faz com que o entre lugar seja discutido e também a própria dependência entre lugares distintos: a relação cultural e comercial entre as três pontas desse triângulo.

Ainda nesse grupo importante de cartas, a carta de número 12 traz o reencontro entre Fradique e Ana Olímpia, que fora retirada das mãos de Gabriela por Arcénio de Carpo (sem a ajuda de Fradique). Não só recuperou Ana Olímpia, mas também Arcénio matara o “animal” (Jesuíno). Trata-se de uma ação em que Fradique fica à margem, como se questões internas àquela cultura, e àquele cotidiano só pudessem ser resolvidos por quem realmente compactua com isso.

Fradique é de fato estrangeiro "em busca de emoções", mas não participa de grandes decisões, não é aqui agente, como parece ser em Eça, tem em si um caráter passivo. Como se o Destino (como entidade) pudesse movê-lo, como se fosse controlado por ele.

Ainda na carta n. 12 há um exemplo de que tudo é contraditório nesse universo, um dos momentos altos do romance se dá quando da descoberta de que vão fugir de Angola dentro de um navio negreiro (o Nação Crioula). A liberdade é dada por meio daquilo que de fato mais representa o mal da escravidão.

Na carta seguinte, ainda a Madame de Jouarre (que "burguesamente" deve adorar o romance escrito por Fradique por meio de suas cartas), a figura de Fradique, neste ponto da narrativa, já se rendeu completamente aos costumes do novo lugar - rendição principalmente metaforizada no sentimento que nutre por Ana Olímpia. Mas ele é de fato representante da metrópole, e não só dela, 
mas sim de toda a modernidade europeia, por isso, em uma festa descrita por ele mesmo diz que é motivo de chacota dos habitantes locais quando é jogado em uma roda de dança.

A metrópole não sairá de Fradique e, após a ida à África, contada por Agualusa, este lugar não sairá dele. O que é então Fradique neste exato momento da narrativa aqualusiana? Português? Africano? Europeu? Fradique se torna híbrido, se torna miscigenado no tocante àquilo que reconhece como cultura. Fradique na verdade se torna a linha que liga dois extremos, a metrópole e a colônia, e nela ele transita, entre lugares.

Em alguns momentos parece ser realmente africano, nos seus rituais, na sua culinária (comendo gafanhotos), e horas parece ter o olhar típico e tradicional europeu, quando ironicamente faz referência aos costumes religiosos africanos e brasileiros (castigas imagens de santos por não terem realizado pedidos):

Quanto a mim fiquei muito impressionado com o Conde e o seu extraordinário manipanso. Se é possível, como me dizem que é, transmitir a voz humana a grande distância através de simples fios de cobre, então porque não há de ser possível a um boneco de pau ter visões e falar?! Imagine, querida madrinha, que se vulgarizava entre nós a utilização de ídolos falantes. Já a vejo no seu jardim de inverno, entre a fresca penumbra das roseiras, puxar de um grosso manipanso e pedir-lhe alegremente notícias do nosso bom Bertrand (por onde andará Bertrand?), um vaticínio para as corridas, ou simplesmente a exata precisão só tempo. (Ibidem, pág. 73).

A carta de n. 13 finaliza com a chegada de Fradique e Ana Olímpia ao Porto de Galinhas e depois a Pernambuco, contando também, mesmo que superficialmente, sobre a negociação de venda dos escravos.

Na carta de número 14, também endereçada a Madame de Jouarre, escrita de Olinda, seguindo aquela proposta narrativa romanesca, Fradique traz à madrinha algumas de suas impressões sobre o Brasil (Olinda e Pernambuco). O que nos pode interessar, em um primeiro momento, é a comparação que faz com a África:

Nas ruas respira-se o mesmo odor melancólico que me surpreendeu em Luanda, um entorpecimento que se transmite das pessoas para as casas, como se toda a população estivesse já morta e a cidade em ruínas. E no entanto há aqui bairros opulentos. Os ricos são odiosamente ricos e ainda mais ricos e odiosos parecem ser por contraste com a extrema miséria do povo. Em Santo Antônio os palacetes ocultam jardins exuberantes, onde à noite se dançam românticos bailes, enquanto os negros dormem exaustos em casebres de palha. (Ibidem, pág. 79)

Há aqui uma percepção bastante apurada sobre a lógica social dessa parte do País. Há para Fradique uma relação direta entre Brasil e África, não só como ele aqui diz, no âmbito dos sentidos, mas também uma relação no âmbito econômico e cultural, como em vários trechos comenta. 
Também no Brasil o espírito aventureiro de Fradique busca conhecer um país em sua essência. Como na África pode fazer tão bem. Busca em viagem para São Francisco do Conde (próximo a Salvador) um País "verídico, autêntico, o Brasil brasileiro, e não este que por aqui se entedia, envergonhado da sua natureza e tentando estupidamente transformar-se num país europeu" (Ibidem, pág. 81). E por um momento reflete na possibilidade de viver em um lugar inóspito, longe de tudo aquilo que a Europa poderia oferecê-lo. Buscaria distanciar-se do "fragor do mundo, vendo pouco a pouco a terra a desdobrar-se em fruto, acompanhando ao crepúsculo o canto dos negros em volta das fogueiras, caçando e pescando, bebendo da água fresca dos riachos [...]” (Ibidem, pág. $81)$.

Certamente esse "devaneio" fradiquiano logo desaparece e ele volta ao seu posto de "representante da modernidade", quando se despede de sua madrinha: Entretanto escreve [...] "Não esqueça as intrigas da corte, incluindo as mais torpes, as polêmicas literárias, o vociferar dos políticos, o relato ruidoso dos últimos crimes" (Ibidem, pág. 82).

Também na próxima carta, a de número 15, vemos um Fradique que vezes é um Jacinto (de A Ilustre Casa de Ramires), vezes é o inegável viajante e descobridor, pois segue viagem para o interior da Bahia, acha tudo de início bastante exótico, bonito, mas aos poucos vai se cansando da paisagem e da quietude, mas acaba, por fim, comprando uma fazenda nos confins da Bahia, que seria para ele e Ana Olímpia um refúgio.

Parece-nos que na carta endereçada a Ana Olímpia (15) Fradique escapa do gênero romanesco e também do gênero epistolar. Parece nela produzir algo que se assemelhe a um diário, pois marca os passos de seus dias (uma semana) para sua amada Ana Olímpia. De fato um amálgama de sentimentos, de descobertas, de gêneros está presente na obra de Agualusa.

A décima sexta carta, endereçada a Eça de Queiroz, nos apresenta uma rápida e detalhada história dos negros no Brasil. Fradique, por meio da pesquisa e observação, como um típico cientista europeu, colhe informações preciosas sobre a presença dos negros no País e as envia para o amigo Eça de Queiroz - com detalhes de lendas e episódios torpes da história. De maneira lúdica, parece Agualusa dizer ao amigo o que ele perdeu, no âmbito narrativo, em explorar mais o Fradique em terras angolanas e brasileiras.

Além disso, o Fradique continuado de Agualusa mostra uma percepção apurada da história e também profundo conhecimento sobre a economia brasileira, colocando na figura do negro escravo uma importância ímpar para a própria construção do País: “[...] os negros carregam o Brasil. Nas cidades nada se move sem eles, nada se faz ou constrói, e nos campos coisa alguma se cultiva sem a sua força”. (Ibidem, pág. 90).

Dois meses depois em uma nova carta ao amigo Eça de Queiroz (carta 17), Fradique Mendes conta que resolveu dar a carta de alforria para todos os negros de sua fazenda, pagando-lhes 
aquilo que os colonos europeus ganhavam nas províncias do sul. Analogamente vemos um Jacinto, que tenta aplicar conceitos modernos em um ambiente rural e tradicional.

Como continuação da carta anterior, proporciona a Eça agora uma viagem não pela história do Brasil, mas sim para o presente tupiniquim. Conta sobre toda a luta dos antiescravagistas brasileiros, principalmente na importante figura de José do Patrocínio.

De fato todo esse "lado da história brasileira", o lado da liberdade, da igualdade, da fraternidade condiz muito com a figura fradiquiana. Por mais que acima ele tenha se admitido como senhor de engenho, trata-se de um novo senhor de engenho. Uma nova proposta em um país corroído pela lepra da escravidão.

Essa escravidão que faz com que Fradique Mendes se coloque politicamente, discuta ferozmente com coronéis, senhores de engenho, na defesa, sempre, das ideias de José do Patrocínio. De fato a principal veia fradiquiana é nesse capítulo colocada à tona: a crítica e a tomada de posição: “Ou seja, parece que encontrei neste país uma nova causa com que entreter o espírito e afastar o ócio. Despeço-me, que se faz tarde, e parto ao encontro da História e da Revolução!" (Ibidem, pág. 99).

Na terceira carta dessa sequência, enviada a Eça de Queiroz (carta n. 18), e ainda com a proposta de contar sobre a história e os últimos acontecimentos brasileiros, no tocante principalmente à problemática da escravidão, Fradique Mendes se coloca mais ativo do que nunca para seu amigo, pois enquanto na primeira se afirmava um novo senhor de engenho (dentro de um ambiente rural), agora se coloca como viajante e afirma estar de viagem marcada para Lisboa, depois para Paris e ainda para Londres, onde supostamente reencontrará o amigo.

O motivo de todo esse movimento é rever os amigos e colher colaboradores para a causa brasileira, para a causa da Sociedade do Cupim (associação antiescravagista secreta a qual se filiou).

A nosso ver esse momento na narrativa de Agualusa se torna um divisor de águas, pois se até aqui tivemos um Fradique até certo ponto passivo, levado pelos novos costumes e levado também pelo sentimento de amor por Ana Olímpia, agora ele começa a se comportar como a fração criada por Eça (mais contestador, mais ativo, mais reflexivo).

Além de se encaminhar à Europa para "recrutar" pessoas para a causa, parte munido: "pois encontro-me na posse de alguns documentos capazes de levantar, uma vez publicados, considerável escândalo" (Ibidem, pág. 102). E recruta seu criador para a causa (Eça).

A apropriação de um Fradique Mendes não estabelece somente um diálogo entre um novo efabulador e a personagem de empréstimo, mas sim uma conversa em grupo, pois os efabuladores parecem dialogar entre si, mesmo que somente no âmbito da ficção e muitas vezes sem intencionalidade disso. Característica mais evidente entre Venâncio e os outros efabuladores, como será visto em 3.1 . 
A narrativa agualusiana, como tende a uma proposta romanesca, encaixa em meio às reflexões da personagem cenas de extrema ação. Como acontece nesta carta a Eça de Queiroz: "Ergui-me de chofre, num pressentimento mau, e no mesmo instante se levantou o homem, levou a mão ao casaco e apontou-me um revolver:” (Ibidem, pág.103). E Fradique, graças a anos da prática da esgrima, se transforma em herói hollywoodiano e se safa da emboscada.

Aqui Fradique (e Agualusa) conseguem proporcionar a sensação de um real perigo que alguém pode passar quando se atreve a enfrentar uma maioria endinheirada (causa morte de Fradique levantada por Venâncio - assassinato). Além de uma força narrativa, esse trecho da carta mostra o que na verdade acontecia (com até mesmo uma analogia implícita ao Brasil do século XX e XXI) nas emboscadas políticas da época. Sem qualquer diplomacia ou diálogo, e sim com muita pólvora.

Na carta de número 19, endereçada a Ana Olímpia, e vinda da Quinta da Saragoça, Fradique conta do ocorrido sobre a tentativa de assassinato. Embora tenha sido algo grave, Fradique afirma não ter ficado assustado com tal episódio, pois está habituado às manifestações de desamor de seus inimigos, "inclusive aos tiros!".

Os contatos diplomáticos não oficiais de Fradique são colocados em prática neste capítulo, quando afirma que fora ajudado por José do Patrocínio, recebendo dele proteção na figura de dois capoeiras: "Contei o sucedido ao bom Patrocínio, e ele, suspeitando que o pistoleiro pudesse ser um assassino profissional, encarregou dois capoeiras de me proteger.” (Ibidem, pág. 107). Mas ironicamente, e aos moldes fradiquianos, escapa também dos olhares protetores de tais capoeiras: "Passei assim o resto da semana a fugir dos homens do Patrocínio e só na segunda-feira [...] é que consegui ver livre deles." (Ibidem, pág. 107).

Fradique parece escapar daquilo que o limitaria ir e vir, já que é um homem livre e do mundo. Tudo aquilo que lhe estabelece uma fronteira é negado pelo poeta e, acima de tudo, deve ser burlado, transposto.

Esta carta carrega, ao tom romanesco, uma cena de terror. Encontra na viagem do Brasil para Lisboa, em seu camarote, uma mala com seu nome, ao abrir vê "olhando diretamente pra mim, com frios olhos de vidro, estava a cabeça empalhada de um homem negro!” (Ibidem, pág. 108). Após isso Fradique reconhece na cabeça as feições do velho Cornélio (seu ex-escravo).

Esta carta nos parece ser um documento que oficializaria a derrota de uma das únicas causas descritas em detalhes e adotada por Fradique Mendes, dentro dos livros estudados, pois ao ter sua mala original trocada pela mala que continha a cabeça, junto com a primeira desapareceram, além de roupas e pertences pessoais, todos os documentos secretos com os quais Fradique pretendia "acordar a Europa do seu torpor de velha, e abanar num repelão feroz toda essa corja de negreiros e escravocratas que se opõe ao progresso no Brasil.” (Ibidem, pág. 108). 
Dando continuidade à discussão sobre a causa escravista e a tentativa de eliminação de Fradique Mendes, na carta número 20, endereçada ainda a Ana Olímpia, percebemos que o tradicionalismo e a manutenção de um estatus quo escravista parecem, nesse momento, se tornar monstros invencíveis, mesmo a um homem de novas ideias.

E todos os homens que ousam ir de encontro com tais forças são deliberadamente eliminados, assim tentou-se com Fradique e, pela "boca pequena”, em Angola todos acreditavam estar morto. Nas palavras do padre Nicolau dos Anjos (com quem Fradique encontra em Lisboa): "Em Luanda toda a gente pensa que V. Morreu.” (Ibidem, pág. 112).

Reaparece aqui o Procurador-de-Cristo, aquele que seria o assassino de Fradique. Mas em uma situação bem diferente da primeira. Após Fradique tê-lo salvo de um atropelamento por uma caleche desgovernada, o homem resolve se ver livre da promessa de matá-lo. Há então um contato, um diálogo entre eles.

Fradique, se não por sorte, por astúcia e perspicácia, ter o poder de transitar por ambos os lados (matador e vítima). Com esse contato de Fradique com o Menino (apelido dado ao assassino, que carrega o nome batismal de Asdrúbal) Agualusa consegue verificar, estudar os dois lados dessa dicotomia: O lado da causa libertadora e o lado do patrocinado pelos escravocratas.

O remetente dessa carta e da anterior, Ana Olímpia, se distancia muito daquela Clara para a qual a fração queirosiana enviava suas cartas de amor. E como dito, se esta era passiva, quieta, como um lago (citado em O Mistério da Estrada de Sintra), aquela era um mar, bravio e cheio de segredos, ou melhor, um navio que transita por sobre um mar, um navio negreiro.

Ana Olímpia traz um arcabouço de conhecimento e de vida que Clara, aparentemente, não traz. Discute, por meio das cartas, questões sobre política, causas, amores, desejos com seu Fradique, enquanto para a outra se limitava aos assuntos do coração. Ana Olímpia chega a ser convidada por Fradique, no final do documento, a apresentar uma conferência aos amigos da Sociedade de Geografia, na Europa, sobre a condição dos negros no Brasil.

A experiência e o arcabouço de conhecimento fazem dessa mulher uma personagem também de extrema complexidade e importância para a teia romanesca criada por Agualusa.

Dois outros elementos nos chamam a atenção nesta vigésima carta, o primeiro é o encontro entre criador e criatura (Eça e Fradique), quando ambos, em uma cena poética, saem em busca de um Portugal cheio de glórias e grandezas. Não o encontram, mas acham na Mouraria e na taverna a essência lusitana: "Fomos os dois, e ali encontramos realmente Portugal, sentado entre vadios e varinas, cantando o fado, cheirando brutalmente a alho e a suor [...]" (Ibidem, pág. 112).

Fradique traz, com isso, não só uma crítica àquilo que Portugal procura ainda ser, procura ainda as glórias das grandes navegações, e não se enxerga na periferia de uma Europa velha e corroída. Há aqui também uma reaproximação entre esse homem e sua terra. Fradique (com seu 
criador) pode não encontrar a grandeza da época de D. Sebastião, mas encontra ainda uma Lisboa lírica e dionisíaca.

Outro ponto que nos chama a atenção é a crítica que Fradique faz em relação à Igreja Católica. Sabemos que Fradique vive no final do século XIX, momento de grande cepticismo, além de o poeta ser também aquele que representa o novo, a mudança, a nova visão.

Para ele, uma igreja nova deveria romper com o Milagre, pois tal fenômeno faz com que a instituição católica caia em descrédito. Fradique aqui, e como em outras suas frações, se aproveita de um assunto (o aparecimento de padre Nicolau) para poder encaixar uma crítica, uma observação mordaz sobre a instituição representada pelo padre milagreiro.

A carta 21 mostra Fradique alegre por receber a notícia positiva da ida de Ana Olímpia para Paris, a fim de apresentar suas experiências na conferência citada. Nessa epístola vemos uma das maiores expressões de relativização de superioridade cultural, ou seja, Fradique, homem moderno, civilizado, após ter contato com a cultura angolana e brasileira (ditas não civilizadas) relativiza a superioridade da cultura parisiense, comparando-a a expressões brasileiras.

O centro da civilização, Paris? Sim, claro! Mas o que é a civilização? Entre o cavalheiro melancólico que frequenta os salões de Madame de Jouarre, minha gentil madrinha, e o remoto canibal do Alto Amazonas, não existe séria divergência moral, apenas gastronômica. (Ibidem, pág. 117)

Ao mesmo passo que relativiza a cultura dos grandes centros, animaliza as relações humanas que a compõem. Homens muitas vezes para terem destaque em uma sociedade animalizada (princípio determinista e darwinista) necessitam se comportar como feras, como canibais. E Fradique coloca aqui essa percepção sobre as relações humanas. Nenhuma cultura é menor, ou mais complexa, ou superior. Todas elas são compostas por canibais.

Para mostrar que a dita civilização é de fato tão animalesca quando aquela dita não-cultura do canibal, Fradique descreve uma cena de terror (lembrando talvez a cena da cabeça de seu antigo escravo): fala sobre um experimento científico com um guilhotinado, em que se aplicou, 45 minutos após sua cabeça ser separada do corpo, uma corrente elétrica, além dela (a cabeça) ser regada com sangre de um cão, para que se roboriza-se. Descreve os movimentos que o rosto do morto fazia por alguns segundos. Olhava para o cientista e parecia expressar raiva.

Trata-se da tentativa de retomar a vida por meio da ciência, fato plausivelmente comparável com o ato canibal, já que algumas das tribos indígenas brasileiras ingeriam carne humana a fim de reviver a coragem do guerreiro que servia de alimento.

A carta de número 22, endereçada a Eça de Queiroz, o poeta discute a questão da produção literária, o quão de experiências um autor deve, ou deveria ter para produzir um soneto, ou somente 
um verso dele:

Pergunto-me, pensando neste espantoso esforço, quantos livros precisou Baudelaire de ler, e quantas vidas teve de viver, para escrever um único verso. Eu pouco li ainda e, ao contrário do que V. Pretende, não vivi sequer o suficiente para escrever um soneto, quanto mais um romance, ou, pior ainda, as minhas memórias. (Ibidem, pág. 121)

Walter Benjamin, em Magia e técnica - Arte e política, dizia sobre a importância das experiências para se contar uma história. De fato isso é levado a cabo por um Fradique que é incitado por seu próprio criador (em Agualusa) para que escreva suas experiências. Parece que aqui e em Venâncio o incitar a escrita faz parte do jogo. Martinho é incitado a produzir literatura, assim como Eça provoca Fradique, ou Agualusa provoca Fradique, ou até mesmo Agualusa provoca Eça em um lúdico processo de "quem sabe mais das experiências de Fradique?", ou "quem cria mais experiências de Fradique?". Agualusa parece fazer com que o criador do poeta valide as experiências contadas em Nação Crioula.

Agualusa traz já algo que será muito explorado por Venâncio que é, como dita, a dicotomia "criar fato histórico" ou "criar deliberadamente literatura". "Na sua última carta, a dado passo, V. duvida que sejam autênticas as personagens de que lhe venho falando, e deduz assim que eu estou já 'fazendo literatura"' (Ibidem, pág. 121). Na verdade aqui Agualusa, ou Fradique, fazem os dois, ao mesmo tempo em que apresentam um quadro político econômico e cultural da Angola do século XIX, o fazem por meio de personagens que não existiram (salvo personagens como José do Patrocínio etc.). "Só a Realidade, na sua vertiginosa e inexcedível insensatez, se atreve a sonhar tais prodígios." (Ibidem, pág. 122).

Entre Eça, Agualusa e Venâncio há de fato uma linha tênue, quase invisível, que separa a criação literária do documento histórico. Este trazendo a Revolução dos Cravos, aquele um panorama da escravidão no século XIX e o primeiro críticas sobre a política lusitana também do final do século.

Fradique é um objeto de ficção tencionando criar Verdade (como ele mesmo diz). Vem no caminho contrário e comum de alguém da esfera da verdade que tenciona criar literatura. Fradique, nesta carta a Eça, nega a criação literária, nega suas memórias, mas, ao mesmo tempo em que faz isso, já prova construir literatura. Seria com negar algo que é óbvio. As Lapidárias estão escritas, suas cartas, secretas ou não, estão escritas, já é personagem de uma ficção queirosiana ( $O$ Mistério), enfim, um personagem que vive somente no âmbito ficcional, mas contraditoriamente há nele as verdades de cada um que se apossa dele.

Assim como um autor (real) cria uma personagem para defender seus pontos de vista, Agulausa promove um processo contrário especificamente nesta carta. Fradique convoca Eça para 
enviar "dia após dia relatórios alarmistas, mostrando como a questão da escravatura domina a opinião pública no Reino Unido. Diga-lhes que é urgente tomar medidas efetivas para acabar com o que resta do tráfico negreiro [...] Enfim, aborreça-os, aterrorize-os!” (Ibidem, pág. 122).

Agualusa, criando esse processo, não provoca somente a reação de "sua" personagem contra todo o processo de escravidão, mas também parece provocar isso naquele que na escala de criação fradiquiana é o grande mestre. Convoca Fradique e Eça de Queiroz para reflexão da condição do negro nos finais do século.

A carta de número 23, endereçada a Ana Olímpia, e que traz o vocativo "princesa", traz logo no seu primeiro parágrafo um Fradique extremamente passional. Conta que recebera uma carta de Arcênio de Carpo, que pressupunha que Fradique soubesse que seria pai.

Tal notícia promove no poeta um misto de amor e raiva: "Fazer um filho é gerar um universo. Hão-de vir os anjos, mas também os demônios; há-de vir o amor, mas igualmente o ódio; e juntamente com o sublime virá o abominável. A mim, que não me agrada o papel de Deus, pareceme um filho um acto arrogante e temerário" (Ibidem, pág. 126); assim como um Brás Cubas, dentro de uma corrente determinista, nega a sua continuidade. Mas esta é também, para toda continuidade desse jogo, determinante. Pois é a partir destes braços, ou troncos de descendentes que outros efabuladores vão criar, principalmente Venâncio e Vidal.

Agora não só nele há a possibilidade de continuidade narrativa, mas sim em seus descendentes. Cria-se cada vez mais possibilidades de criação, se não nos "buracos" deixados na biografia fradiquiana, em seus descendentes. Talvez não tão interessantes quanto o poeta das Lapidárias.

Já no Brasil, Fradique escreve uma carta à madrinha, a de número 24. Nela o poeta satânico conta sobre ser um novo Fradique, agora pai. Parece dividir-se em dois momentos, antes e depois de Sophia. De ocioso, irresponsável, pensador de ideias emprestadas, usurpador de sentimentos alheios para conhecedor das filosofias e dos mistérios sagrados. A paternidade para Fradique se torna chave, mesmo após negá-la, pois é dessa experiência, como tudo em Fradique parte da experiência, que se reconhece, se critica e se avalia.

Nesta carta à madrinha Fradique inicia uma descrição do Brasil que, feita nos finais do século XIX, poderíamos dizer que fora ironicamente profética. As consequências do final da escravidão no Brasil poderiam

assinalar também o princípio do fim do homem negro no Brasil. Permanecerão talvez as danças, e veremos senhoras de pele branca a praticar a umbigada nas rodas do batuque; hão-se continuar os velhos deuses africanos, e ficará uma vaga, distante, memória da escravidão. O resto será apenas cinza e sombra. (Ibidem, pág. 128). 
Uma percepção do futuro bastante condizente com o que vimos hoje (Agualusa parece dar a Fradique uma visão bastante aguçada das consequências dos atos, tornando-o, também, um personagem do futuro - como afirma em entrevista Fernando Venâncio).

Conta à sua madrinha sobre como anda a política e todo o processo de revolução antiescravagista brasileiro. A notícia da filha certamente corrobora o percurso argumentativo sobre a igualdade entre as etnias e o apoio a uma conquista negra, já que Sophia (nome que tem como significado o conhecimento) seria a metáfora dessa união e desse respeito entre negros e brancos. $\mathrm{O}$ nascimento de Sophia, para Fradique, pode ser comparado ao nascimento de uma nova ordem étnica mundial, que é o que afirma na carta.

A penúltima carta de Fradique (ou a última levando em consideração que a carta de número 26 foi escrita por Ana Olímpia ao escritor Eça de Queiroz) é composta por uma resposta negativa ao seu destinatário Eça de Queiroz, afirmando não ser possível escrever um artigo sobre a "Situação Atual de Portugal em África". Durante a carta Fradique explica os motivos pelos quais não seria coerente escrever sobre.

Coloca-se aqui com um olhar colonizador: "meu silêncio, portanto, é patriótico. Se permanecermos quietos e calados pode ser que o mundo, ignorando que não estamos no Congo, na Zambézia ou na Guiné, nos deixe continuar a não está lá.” (Ibidem, pág. 131).

O português Fradique Mendes toma voz nesta carta. Coloca-se patriota mesmo dissertando sobre a insignificância de Portugal do século XIX frente as "grandes potências". Um Portugal pequeno e que por esquecimento de todos ainda persiste na África. Aproveita para criticar o processo de exploração portuguesa: “A nossa presença em África não obedece a um princípio, a uma ideia, e nem parece ter outro fim que não seja o saque dos africanos.” (Ibidem, pág. 132).

Também há uma crítica mordaz sobre o processo de colonização brasileiro: "O que é que nós colonizamos? O Brasil, dir-me-ás tu. Nem isso. Colonizamos o Brasil com os escravos que fomos buscar a África. Fizemos filhos com eles, e depois o Brasil colonizou-se a si próprio.” (Ibidem, pág. 133). Coloca na carta a questão discutida por Boaventura de Sousa Santos, e já citada na introdução, sobre o imaginário lusitano. Remontando todo o sebastianismo e as grandes navegações.

Fradique cita: “Ao longo de quatro demorados séculos construímos um império, vastíssimo, é certo, mas infelizmente imaginário. Para o tornar real será necessário muito mais do que a nossa consoladora fantasia de meridionais." (Ibidem, pág. 133). Coloca nesta carta chave (que a nossa ver resume toda a proposta de livro de Agualusa) alguns devaneios que contraditoriamente parecem bem mais coerentes do que o que foi todo o processo de colonização africana. 
Para construir uma África portuguesa seria necessário que Portugal se fizesse africano. Atrever-me-ia a sugerir [...] que se mudasse para Luanda a capital do Reino e a Corte, a Câmara dos Deputados, todos os Ministérios e, naturalmente, os pastéis de Belém. Numa segunda fase seria necessário mudar também os Portugueses, inclusive os virtuosos e os trabalhadores, transferindo para Portugal os criminosos a cumprir pena de degredo em Angola e Moçambique. Portugal, território pequeno e nessa altura já quase despovoado, poderia então, sem prejuízo, ser governado por um qualquer empacaceiro em comissão de serviço. (Ibidem, pág. 133)

A experiência pela qual Fradique passou na África leva-o a dizer, com conhecimento de causa e intensidade, sobre um processo de africanização real do português. Por ter conhecido de perto a enganosa e cruel logística da colonização de Angola, e após ter passado por um processo intenso de africanização, pode imaginar como seria se Portugal como um todo tivesse também se africanizado.

De fato a obra de Agualusa promove, a nosso ver, direta ou indiretamente, uma africanização do leitor, seja ele português ou brasileiro. Levanta uma temática, que como Fradique mesmo diz, esquecida pelos brasileiros e pelos angolanos; uma temática delicada, a colonização do final do século XIX e, consequentemente, seus malefícios para a modernidade.

Desgraçadamente Portugal espelha-se, não coloniza. Somos assim, enquanto nação, uma forma de vida mais rudimentar que o Bacilo de Koch. Pior: uma estranha perversão faz com que os Portugueses onde quer que cheguem, e temos chegado bastante longe, não só esqueçam a sua missão civilizadora, isto é, colonizadora, mas depressa se deixem eles próprios colonizar, isto é, descivilizar, pelos povos locais." (Ibidem, pág. 134)

De fato se todas essas informações, todas essas críticas tivessem por fim algum artigo de revista Portugal não mais poderia se enganar na África, na Ásia ou em qualquer outro lugar onde tencionariam espalhar-se (como um Bacilo, para usar as palavras de Fradique).

Nesta carta, e em todos os momentos em que Fradique fala se sua pátria, percebemos que isso é feito com certa amargura. Ao mesmo tempo em que tenta encontrar (e às vezes acha) lirismo em uma Lisboa das tavernas, dos cafés. Não se contém frente àquilo que ela promove no tocante à falta de discernimento em seu processo de colonização. E isso acaba se elevando proporcionalmente à medida que Fradique vai se africanizando.

Passa a tomar pra si as dores daqueles que sofrem por causa da metrópole, metaforizada, vezes, pelo próprio Fradique. Sua experiência ganha cores que vão muito além daquilo que um flâneur poderia ver, pois este enxergaria nos boulevards as cores de um cotidiano que faria parte de um estatus quo burguês e aristocrático.

Nada disso chega à intensidade que Fradique pode sentir vivendo na África, defendendo a causa abolicionista no Brasil, ter se tornado pai de uma mestiça. De fato aqui há uma fração do 
Fradique que escapa, ou melhor, extrapola de maneira exagerada tudo aquilo que o simples viajante poderia visualizar e sentir.

"E aqui tens, resumidamente, os motivos porque ainda desta vez não acrescentei o meu nome ao ilustre rol de colaboradores da Revista de Portugal. Aguardo as tuas notícias, e o teu perdão. Um abraço.” (Ibidem, pág. 134).

Após o último contato com o seu criador, Fradique se despede da obra agualusiana, para que seu desfecho seja feito por uma das personagens principais da obra, Ana Olímpia.

A última carta (de Ana Olímpia para o escritor Eça de Queiroz, carta de número 26) inicia com um aparente desagrado em relação às publicações das cartas de Fradique, pelo amigo Eça de Queiroz: "Poucos meses depois, ao folhear a Gazeta de Notícias, do Rio de Janeiro, soube que V. tinha decidido ignorar minha opinião [Carlos manter-se morto depois de morto]” (Ibidem, pág. 137). Mas logo após afirma que o "desrespeito" fora providencial e bem visto.

Retoma também a afirmativa feita pelo escritor quando da biografia de Fradique Mendes, o desejo de que a vida do mais português dos portugueses não caísse no esquecimento: "pois nos tempos incertos e amargos que vão, Portugueses destes não podem ficar para sempre esquecidos, longe, sob a mudez de um mármore” (Ibidem, pág. 137).

Impraticável para este jogo manter Fradique "morto" (esquecido) depois de morto. Na verdade todo o jogo das efabulações tenta fazer o contrário, torná-lo cada vez mais vivo, recontando-o dentro de cada uma de suas frações. Como Ana Olímpia diz em carta: [Fradique será] um morto, nu, deitado de costas, sujeito à voraz indiscrição da turba" (Ibidem, pág. 138).

Duas das mais pertinentes definições de turba são: multidão de pessoas e coro de vozes. Quem são estes se não os próprios efabuladores? Aqueles que observam, estudam o cadáver, fazem experimentos e principalmente conjecturam passagens da sua vida. Ana Olímpia (e Agualusa) parecem estar conscientes do potencial escondido nessa personagem.

Ao mesmo tempo em que frações desta personagem pertencem aos seus efabuladores, um todo chamado Fradique Mendes não pertence a ninguém. Fradique já fora construído para não pertencer inteiramente a ninguém, já que fora criado a várias mãos, depois tomado de empréstimo por vários outros. "Fradique não nos pertence, a nós que o amamos, da mesma forma que o céu não pertence às aves" (Ibidem, pág. 138).

Ana Olímpia, no início de sua carta reflete sobre essa questão do pertencimento. Publicar o não as cartas? Fradique como homem do mundo. Parece aqui haver uma voz do efabulador, mais do que em qualquer outro momento, não no tocante a aquilo que Fradique pronuncia, defende, mas no tocante àquilo que Fradique é, como substância, como elemento, como representação.

Agualusa parece dar o arremate daquilo que se propõe fazer como gênero: "As suas cartas podem ser lidas como os capítulos de um inesgotável romance, ou de vários romances, e, nessa 
perspectiva, são pertença da humanidade.” (Ibidem, pág. 138). Já que pertence à humanidade, logo, a intromissão e o empréstimo estão autorizados, para que se construa um romance, ou vários romances.

Preferimos levantar a proposta de fração de um único romance, de uma única vida. Mas o que nos chama mais atenção nesse excerto é o fato de Ana Olímpia (Agualusa) trazer a expressão inesgotável.

De fato, e os efabuladores nos provam isso (tanto dos romances, quando da imprensa lusitana), Fradique Mendes é inesgotável.

Após essa discussão, Ana Olímpia começa a contar sobre a sua vida, antes e depois de Fradique, com quem viveu momentos de protagonista, diferente da "vida na janela" proporcionada por seu último marido Arcénio de Carpo.

O leitor passa a saber da vida de Ana Olímpia pelas palavras dela. Passagens, acreditamos, desconhecidas do próprio Fradique. Seu casamento com Victorino, as torturas que sofreu quando voltou à condição de escrava, suas sensações sobre todo esse processo e principalmente, o que julgamos coerente para a própria proposta agualusiana do gênero romance, nela parece que nos é apresentada uma finalização na biografia das personagens.

Passa a nos ser de conhecimento a loucura de Santamarinha, e o casamento com Arcênio de Carpo (sabemos também que este era apaixonado por Ana Olímpia desde o início da narrativa). Agualusa, pela voz de Ana Olímpia, finaliza o seu romance, dando a Eça, e consequentemente aos outros, o aval para a continuidade.

Parece fechar as portas de Angola, dando um final para as personagens, mas Fradique nunca perderá a voz, seja na África, seja no Brasil, seja em Portugal, ou em qualquer lugar do planeta. 


\section{III - ESQUEMAS}

\section{1 - ENSAIO DE UM EFABULADOR}

O romance de Fernando Venâncio, como trabalhado acima, funciona em todo o processo efabulatório como uma capa que cobre aquela corda de fios entrelaçados. $\mathrm{O}$ autor retoma em muitos dos momentos o trabalho de alguns dos efabuladores. E isso se dá por meio de uma pesquisa feita pelo protagonista do romance, o jornalista Martinho Telha.

Este é instigado por um lado por Cristiano Fradique Mendes (descendente direto de Carlos) que o paga pelos serviços - a produzir um texto de caráter histórico, tentando traçar um percurso real do grande "homem do século"; e é provocado por outro lado por sua amiga Valéria, professora universitária, que a todo o momento lê a produção do jornalista como ficção e o provoca para que (re)invente dentro daquilo do que já foi feito sobre Fradique.

Martinho está no limiar do que julga verdade, real, e do que aparentemente é ficção. Não há certamente a preocupação em delimitar aquilo que é histórico, há sim uma preocupação na reflexão da própria relatividade da história, "a história poderia ter sido assim".

"No decorrer do texto, percebem-se dúvidas do próprio personagem em acreditar na existência de Fradique Mendes. Na leitura inverte-se esta ideia, e como Eça de Queiroz, Fernando Venâncio constrói a narrativa tentando convencer o leitor da existência real de Fradique Mendes" (BRESSAN. 2009. pág. 6).

A obra se encaixa na definição da metaficção historiográfica:

A ficção contemporânea que está nos (i)limites do pós-moderno, em que as fronteiras são explicitamente fluidas entre o romance e a coleção de contos, entre o romance e o poema longo, o romance e a biografia, o romance e a história. [...] De fato, para ser classificada como metaficção historiográfica, a obra deve ter as seguintes características: o caráter de autorreflexividade intensa e, paradoxalmente, referências explícitas a personagens e eventos históricos; a imbricação de reflexões literárias, históricas e teóricas; o trabalho que realiza a partir das convenções com o objetivo de subvertê-las; e a defesa de que, apesar de não negar a existência da história, o passado só nos é acessível por meio da textualidade. (HUTCHEON, 1988, pág. 34)

Há em Esquemas de Fradique uma fluidez, como diz Hutcheon, o romance e a biografia, e o romance e a história. Há nós intrincados entre o que é história (a tentativa de produção de um percurso de um personagem muito próximo da realidade histórica, a tentativa de se reconstituir a 
personagem de Eça e Agualusa), romance (trechos que, irresistivelmente, Martinho produz que são nada mais que conjecturas e invenções sobre Fradique) e biografia (que transita também pelo limiar da realidade - ficção):

Na voz de Cristiano: $<<$ Conheci bem Dom Manuel $>>(\ldots)<<$ Era intencionalidade
do novo rei criar um governo que ele dizia 'de grandes espíritos'. Ia por, mas tudo
isto se sussurrava, o Oliveira Martins na Fazenda, o meu avô nos Estrangeiros e o
Eça em outra qualquer coisa (...) Só se conseguiu o que o senhor doutor sabe, o
Oliveira Martins, nas Finanças, e mesmo assim para acabar naquele fiasco, há-de
perdoar o termo. > (VENÂNCIO. 1999. pág. 35)

Em 1892, Oliveira Martins foi realmente nomeado para a pasta da Fazenda, no ministério que se organizou sob o governo de Dias Ferreira. E também outra informação pertinente e que nos cabe também curiosa é o fato de, supostamente, Fradique ser nomeado para a pasta dos Estrangeiros.

Acreditamos que há nessa proposta uma coerência com tudo aquilo que Fradique representa: homem emancipado, visão aguçada e cidadão do mundo, como diz o próprio Venâncio em ensaio comentado.

Há em Esquemas de Fradique também a questão metalinguística, um movimento de estudo da própria linguagem, do próprio gênero. Um texto que discute a questão da paródia. Um romance, ou ensaio, como prefere o autor, que parodia textos que já foram constituídos de paródia. Há a nosso ver um movimento cíclico intenso nesse processo de intertextualidade:

A paródia é, pois, uma forma de apropriação que, em lugar de endossar o modelo retomado, rompe com ele sutil e abertamente. Em outras vezes a paródia, ainda que conservando suas características de rompimento, presta uma homenagem ao texto retomado ou ao seu autor (...) Na visão de Paulino et al (1995), a paródia sempre se estabelece na literatura e na sociedade como um canto que desafina o tom elogioso, bem comportado, conservador das práticas discursivas hegemônicas. (...) José Leon Machado, em novembro de 1999, escreveu um ensaio no quem afirma que Fernando Venâncio parodiou os romances intertextuais e acabou por parodiar a si próprio. (BRESSAN. 2009. pág. 6)

Valéria, a figura da pesquisadora, que por senso comum provocaria para a verdade, quebra esse tabu e instiga o jornalista na produção de literatura. Abaixo um trecho que mostra qual era a área de pesquisa da professora:

Depois, a dissertação, que rumava sobre a Geração de 70, ameaçava descarrilar. Acumulavam-se-lhe provas - explicava ela - de que a veneração dos amigos por Antero era, sobretudo, uma forma de má consciência, e por isso uma cola demasiado fluída para ligá-los mais do que a duração de um jantar. (VENÂNCIO. 1999. pág. 15) 
E, ao analisar os textos que Martinho produzia, fazia indicações de que essa "história" não poderia ser feita somente para a leitura e bel prazer do dr. Fradique (Cristiano), que outras pessoas tinham de ter contato com o resultado:

Disse que eu tinha muita piada, que mostrava informação e mesmo algum $<<$ talento〉>. Que, se <<historicamente〉> nem tudo bateria certo, também era verdade que as preocupações do leitor não iriam por aí. (...) $<<$ Não me vais dizer que andas a escrever esta história só para o velhote. $>E$ logo me fez ver que, visto o senhor me ir pagar bem, e até largamente, eu podia tirar depois uns meses para sacar dali um romance. Um romance. (VENÂNCIO. 1999. pág. 30)

O livro de Fernando Venâncio inicia já com um texto efabulado por um narrador, Martinho, o jornalista contratado por Dr. Cristiano Fradique. Após conjecturar uma passagem da vida do poeta de Lapidárias, pintando-o sempre com tintas da nobreza e da aristocracia portuguesas, entra em uma discussão sobre sua própria produção.

É contratado por Cristiano para trazer a vida real de Fradique: "Dê-me dados, dê-me datas, doutor Martinho [...] Descubra o que fez o meu avô, o que disse, com quem de importante andou. E não extrapole, não efabule!” (Ibidem, pág. 11), do outro lado parece haver uma força que determina uma criação ficcional dessa personagem, uma força não descritiva, como quer Cristiano, mas criativa, como quer o próprio autor (Martinho) e posteriormente Valéria (profa. universitária):

Claro que haverá, a 22 de Maio, numa engalanada igreja de São Domingos, o casamento dos príncipes, e não me custará nada engendrar as festividades de rua, iluminações, bailes noite fora, pândegas, desacatos. Depois, acalmada a cidade, pode aparecer a Ratazzi flanando, já um tanto incógnita, pelo Chiado, sozinha, ou dando o braço um charmoso, e se possível ainda mais incógnito, Fradique Mendes. (Ibidem, pág. 11)

Há duas forças agindo sobre o jornalista Martinho, a força da criação e a força dos fatos. Mas quando se trata de Fradique Mendes essas forças não são díspares, são concomitantes e andam em um mesmo sentido. De fato Fradique Mendes é uma criação, mas tem uma força e presença tão marcantes que quando Martinho discute entre a criação e o fato essa personagem toma ares de realidade.

Já desde a sua origem latente, Fradique Mendes, com A Correspondência de Fradique Mendes toma uma voz real, toma a crítica pra si e é dono de um estilo tão próprio que se torna um escritor, dá-se a ele uma função autor, como trabalhado acima, mas se tratando de um personagem de ficção essa função autor de desdobra, se modifica. Essa modificação é vista também aqui em Venâncio. 
Alguém (Martinho) que vasculha a vida de um autor que julga real, mas começa a conjecturar seus passos, como se fosse algo impossível de controlar. Tudo o que fez Fradique é importante para todo o processo ensaístico de Martinho, já que esse narrador tem o poder de modificar a própria realidade, se a vertente conjectural falar mais algo, o neto (realidade) de Fradique irá ter uma visão falsa do que foi o avô, mesmo que tudo isso aconteça no âmbito da ficção.

Na obra de Venâncio podemos dizer que Valéria, a professora universitária e pesquisadora da geração de 70, poderia metaforizar a criação, a conjectura, por mais que contraditoriamente seja aquela quem apresenta a Martinho as fontes de pesquisa. Do outro lado, em uma mesma direção está o Dr. Cristiano, personagem da ficção, resultado de interação fradiquiana com o mundo, cobrando traços reais da passagem do avô.

Um personagem que trás no seu cerne essa dicotomia realidade e ficção. Acreditamos que Fradique Mendes nunca estará somente no universo ficcional, mesmo tendo a certeza de que fora e é criação. Uma das regras desse jogo é tornar sempre evidente a mística de realidade que traz Fradique Mendes.

Esse jogo, essa mística da realidade em Fradique Mendes, é promovido, de maneira lúdica também, com a constatação da utilização de uma obra ficcional como documento histórico, como realidade. Martinho (Venâncio) busca como fonte real aquilo que foi feito por José Eduardo Agualusa, em seu Nação Crioula, para provar a existência do Dr. Cristiano Fradique.

Carlos Fradique Mendes - é de conhecimento público - partiu, em outubro de 1876, da capital de Angola para o Brasil, levando consigo a noiva, Ana Olímpia Vaz de Caminha, que contava então vinte e seis anos. Tinham se conhecido oito anos antes no cais de Luanda [...] Tudo isto o descobriu José Eduardo Agualusa, que reuniu em "Nação Crioula" umas vinte e cinco cartas de Fradique desconhecidas. (Ibidem, pág. 18)

É aqui a ficção sendo usada como documento. E nessa proposta de ironizar a própria produção ensaística, Venâncio vai além nesse jogo. Ironicamente brinca com a ideia de que o romancista Eça de Queiroz deixou escapar de suas mãos qualquer indicação sobre a mulher de Fradique Mendes, Ana Olímpia. "Mais: não existe na correspondência do romancista a mínima referência à mulher de Fradique. Parece-me importante sublinhá-lo” (Ibidem, pág. 20).

Até mesmo a relação entre Eça de Queiros e sua esposa é explorada: “Terá Eça querido poupar a mulher ao conhecimento das relações dum amigo tão íntimo com uma senhora negra, misto bizarro de princesa e escrava? Terá Maria Emília algum dia sabido tudo por outras vias [...] ?” (Ibidem, pág. 20). Não somente é efabulada a vida de um Fradique Mendes, mas também episódios da vida de Eça de Queiros. Parece-nos que Fradique Mendes é um convite para a 
efabulação e, nesse trecho de Esquemas, parece também convidar à efabulação dos que os rodeiam, já que Eça (o narrador de Correspondência) foi amigo íntimo do janota.

No capítulo 4 da primeira parte, Martinho reflete sobre sua relação com Tânia, a que seria sua namorada, e com Valéria, e que, de maneira subentendida, seria sua amante e professora, quem também lhe conseguiu o contato com o Dr. Cristiano. Mas o que nos interessa aqui é a expressão usada pelo jornalista quando se refere àquilo que o Dr. Cristiano quer dele: o "resto" sobre Fradique. A todo o momento, não só aqui em Esquemas, como também em Agualusa e em Perry Vidal, há sempre uma trajetória em busca dos "restos" fradiquianos. Martinho a cada capítulo traz esses pedaços, acreditando trazer a verdade, conjectura elementos soltos: "Outra descoberta minha [...] foi a de que os contatos parisienses do bon-vivant com a princesa Rattazzi não se ficaram pelos culturais" (Ibidem, pág. 24).

A segunda parte deste mesmo capítulo é composta por um suposto encontro entre Fradique Mendes e Rattazzi. Conversam sobre um livro que seria a história de Portugal, ainda não escrito. Fradique fala dos amigos Eça e Ramalho, das Farpas, criticam Enes, que na visão fradiquiana é "simples imitação tosca do teatro romântico", já Rattazzi o admirava. Enfim, Martinho acaba trazendo os seus restos, acaba em cada momento trazendo sua fração de um Fradique maior, que levantamos aqui.

Mas como dito na introdução, acreditamos que Venâncio vai além de criar sua fração fradiquiana, cria ele uma malha que envolve tudo aquilo que foi criado sobre a personagem, e se utiliza disso para criar sobre a criação alheia.

No capítulo 5 há um trecho em que Valéria incita a produção literária de Martinho, se produção literária, ficção, efabulação: “E logo me fez ver que, visto o senhor me ir pagar bem, e até largamente, eu podia tirar depois uns meses para sacar dali um romance. Um romance." (Ibidem, pág. 30). Valéria também coloca aqui o papel dos possíveis leitores do texto de Martinho. Lembrando que inicialmente a proposta eram relatórios sobre a vida de Fradique para um só leitor, o Dr. Cristiano.

Quando Valéria discute o fato de Martinho não produzir somente para o Dr. Cristiano, coloca o jornalista em outro patamar, não mais somente de jornalista investigativo, mas sim de autor literário. Insere-o no patamar daqueles que efabularam sobre Fradique Mendes, um Eça, um Agualusa, um Perry Vidal, entre outros que não foram contemplados aqui.

É ainda nesse capítulo que nos aparece uma questão chave para o romance, a descoberta (com base em Vidal) de outro galho na árvore genealógica fradiquiana: Fradique Mendes tivera um filho, além da já conhecida Sophia, que tivera com Ana Olímpia (da obra agualusiana), personagem essa que vai ser mote para remontar toda uma nova narrativa para Martinho. Nessa malha criada por Venâncio há a tentativa clara de unir alguns pontos da vida desse Fradique maior. Tenta preencher 
ludicamente algumas lacunas, alguns contatos e unir personagens improváveis que fizeram parte das efabulações.

No capítulo 6 há uma mostra peculiar desse fenômeno: no momento em que Martinho apresenta sua pesquisa para o Dr. Cristiano, este comenta com o jornalista sobre a ajuda que deu para o escritor José Eduardo Agualusa, as pistas para que o escritor angolano pudesse trazer as peripécias de Fradique na África: "Claro que este escritor angolano, esse Agualusa, nome, aliás, muito nosso, claro que foi ele quem andou a investigar mais de perto. De resto, obviamente, fui eu [Cristiano] a fornecer-lhe pistas" (Ibidem, pág. 34).

O capítulo 7 traz já desde o início um fato que é, para obra de Venâncio, preponderante. Até o momento, todos os efabuladores tratam de um Fradique que teria sido real, isso Venâncio também faz, mesmo que de maneira lúdica. Mas o autor de Esquemas de Fradique traz um elemento que certamente faz com que seu personagem faça definitivamente parte de um mundo real: a fotografia. Até o momento não havia aparecido esse espólio, é de fato materializar a personagem: "Estas fotografias de Carlos Fradique Mendes, doutor Martinho, mais ninguém entre os vivos, afora eu, e agora você, pode afirmar tê-las visto" (Ibidem, pág. 39).

Também neste capítulo o narrador fala sobre Libuska (Madame Lobriska), mulher que teoricamente fora amante de Fradique Mendes: “essa relação eslava, pude apurá-lo, é uma página mal conhecida na vida do célebre homem. Mal conhecida, ou que se tentou esquecer, se não mesmo apagar" (Ibidem, pág. 40/1). Parece aqui haver um potencial narrativo. Zona a ser explorada. (fato levantado por Antônio Sardinha, fonte apresentada pela professora Valéria - aqui mais uma tentativa de unir os pontos).

Ainda no capítulo 7, Martinho comenta sobre objetos que dão título ao livro de Venâncio: "Eram apontamentos curtos, encimados por datas, em caligrafia variável, aqui apurada, além de garatujas, com iniciais, diagramas e esquemas" (Ibidem, pág. 41). As definições de "esquemas" trazidas pelo dicionário Houaiss são: representação gráfica simplificada e funcional de objeto, processo etc. Exposição das ideias gerais de uma obra literária, projeto etc. Plano.

De fato a palavra "esquema" traz em si o próprio processo de efabulação fradiquiana. Tomar essa personagem, ou seja, efabular é estabelecer um novo processo, infinito, um “estar por vir”, é criar planos dentro de um jogo muito bem delimitado. Das obras que efabulam Fradique Mendes essa é realmente a que mais coloca em prática o "planificar", o "projetar", já que se trata de uma obra ensaística, busca tudo aquilo que fora feito e articula cuidadosamente em um novo plano ou rede narrativa.

No capítulo 8 há a introdução de uma personagem que traz à tona um processo que vem sendo trabalhado em capítulos anteriores, mas aqui com mais expressividade: Eugênio, primo de Tânia, ao acompanhar o casal em um jantar diz ser conhecedor de tudo aquilo que Fradique 
publicou. Mas Eugênio traz o Fradique fabular, o Fradique inventado pelos amigos escritores. Ao mesmo tempo em que discursa sobre todo o processo de origem de um Fradique Mendes não real, Martinho se desliga do ambiente, como se não quisesse ouvir sobre um Fradique que não o interessava, já que, se ouvisse, sua própria narrativa perderia força, pois acreditar em um Fradique não real era não acreditar na existência de um Cristiano e em sua própria existência. "O Eugênio, percebendo-me desligado, virou-se para melhor auditório [...] Ali estava o nosso priminho fabricando historietas." (Ibidem, pág. 45).

Nesse episódio há até mesmo uma discussão bastante acalorada entre a verdade e a mentira sobre a real existência de Fradique Mendes. Cada um se utilizando de suas armas: o primo com relatos históricos sobre a Revolução de Setembro, os versos de Jaime Batalha Reis e as criações de Eça e Ramalho. E do outro lado a verdade com as fotos brasileiras de Fradique Mendes e as conversas com o Dr. Cristiano.

No capítulo 9, em carta do Dr. Cristiano a Martinho, em resposta do que este escrevera sobre Fradique Mendes, Cristiano recusa a produção de Martinho dizendo-a literária, ficcional. Traz dados que desmentem fatos descritos pelo jornalista e ameaça retirá-lo da demanda. Isso faz com que Martinho faça reflexões plausíveis sobre exatamente a questão levantada na tese: As efabulações são frações de um mesmo Fradique, com suas nuances e propostas dentro de cada efabulador, mas respeitando uma linha coerente de efabulação: “[...] os rastros são, por vezes, mais do que um. Como se Fradique Mendes tivesse conhecido vidas paralelas” (Ibidem, pág. 51). Por mais que haja a ideia de vidas paralelas, o romance de Venâncio tenta, e consegue mostrar que há sim, esquematicamente, um processo de criação de um único ser, criado a várias mãos, e que contempla uma mesma linha narrativa.

No capítulo 11, há um fenômeno que ocorre também em Nação Crioula, quando o narrador, no caso deste, Fradique, no caso daquele, Martinho, relativiza a questão da modernidade e da civilização, colocando muitas vezes em pé de igualdade a metrópole e a colônia:

Quantas vezes não ponderou Ana Olímpia a partida para Paris, onde tinha casas, conhecimentos e até um cônsul amigo. Mas, se a assustava uma Sophia entregue a algum boçal negreiro luandense, não menos a arrepiava a imagem da filha flanando pelo braço de algum janota na Rua Rivoli. (Ibidem, pág. 58)

Ana Olímpia, por ser uma mulher esclarecida, vê e tem a capacidade de comparar dois mundos que aparente e culturalmente são bem diferentes, mas trazem uma mesma essência, aqui um negreiro é comparado a um janota e ambos praticam a manutenção de um status quo que devem favorecer a ambas as classes, um não é menos ou mais civilizado do que outro; ambos trabalham, e têm a consciência disso, para que as coisas fiquem no seu devido lugar social. Logo, agem 
igualmente dentro de uma sociedade não igualitária em direitos. Venâncio, neste mesmo capítulo, parece dar continuidade ao texto de Agualusa, conjecturando, por meio de seu narrador Martinho, os passos futuros de Sophia. Nessa trajetória feita pelo autor, parece aproximar a "menina" da terra natal de seu pai.

De fato Sophia não era portuguesa, era brasileira, resultado da união entre África (Angola) e Portugal. Mas Venâncio parece querer fazer as pazes de um resultado fradiquiano com Portugal, tanto criticada em A Correspondência e até mesmo em Nação Crioula: "[...] E a Paris iria, muitas vezes ainda. Mas foi Lisboa que a conquistou. [...] à filha falava [...] de uma cidade cor-de-rosa, na margem de um rio azul, lá longe, longe, aonde ele um dia haveria de levá-la" (Ibidem, pág. 59). E mais, além de colocá-la na cidade de origem do "homem do século", faz com que ela entre em contato com os supostos amigos do pai, entre eles Jaime Batalha Reis: "Ele chorou-lhe nos braços, chamou-a 'a minha Sophia'”' (Ibidem, pág. 59).

Este livro, de maneira geral, pode ser entendido como uma reaproximação de Fradique, e de tudo o que ele representa em relação a Portugal. No final deste capítulo há então a explicação da origem de Cristiano Fradique Rolo. Resultado da união entre Sophia e Dinis Rolo, pretendente apresentado pelas filhas de Jaime Batalha Reis.

O capítulo 13 traz um elemento importante para nossa análise: a casa do Dr. Fradique (Cristiano) fora roubada e com isso o fato de vários documentos terem sido levados; logo, parte do espólio de Fradique Mendes não será visto, mostrado. Isso é uma constante em todo o percurso fradiquiano, cria-se uma expectativa sobre algo ainda não conhecido sobre Fradique, mas isso muitas vezes se desfaz. Assim foi com o espólio deixado com Libuska e assim será também com o caderno de fotografias e alguns outros documentos deixados com Cristiano.

Como Fradique pertence a um "por vir", criar sempre uma expectativa de algo novo faz parte da construção dessa personagem, primeiro porque há sempre a ideia de que esse Fradique nunca é totalmente conhecido, segundo, abre-se sempre precedente para coisas serem descobertas, e em terceiro lugar, abre-se espaço para a criação de novas trajetórias e de novos espólios, gerando assim, como afirmado, um ciclo contínuo de possíveis descobertas e novas criações.

No capítulo 14 há o desfecho de algo levantado no anterior, o roubo do espólio fradiquiano. Valéria é vista como suspeita por Martinho, mas esta acaba por dizer que Baltasar Touriga pode ser o larápio, fato comprovado.

Baltasar Touriga é aquele que vinha tentando produzir uma edição definitiva de $A$ Correspondência de Fradique Mendes. Mas o que seria uma edição definitiva dessa obra? Tratar-seia de fato de uma obra que nunca poderia ser editada, já que não se conhece tudo o que Fradique produziu e muitos documentos foram perdidos, logo, seria impossível reunir aquilo que fora de produção fradiquiana, até porque sempre há algo a se descobrir, ou melhor, sempre há algo a se 
criar sobre Fradique Mendes e sobre aquilo que ele supostamente tenha dito em cartas, romances, bilhetes, encontros (recibos de lavanderia) etc. A palavra "definitivo" não cabe a Fradique Mendes.

O capítulo 15 (que introduz a segunda parte da obra - Leonor), já em seu primeiro parágrafo, Martinho diz ter encontrado outra descendente de Fradique Mendes, Dona Leonor Fradique Mendes. Neste capítulo a própria Leonor fala sobre sua origem, sobre a relação de seu avô, Fradique Mendes, com Libuska (Varia Lobriska), ela seria então filha do Príncipe de Palidoff, levantado e conjecturado por Frederico Perry Vidal, em sua obra O Único Filho de Fradique Mendes, publicada em 1950. E essa informação sobre Vidal, quem entrega a Martinho é a própria Leonor, como se ali houvesse toda a história de seu pai (em uma obra de ficção?):

"Não temos muito tempo pra isso. Você, agora, vai trabalhar é pra mim". Sacou da
bolsa um embrulhinho e estendeu-mo. "Abra". Tirei de lá um pequeno livro, de
aspecto antigo. Era autor um certo Frederico de Sá Perry Vidal. A obrinha
chamava-se "O único filho de Fradique Mendes". (Ibidem, pág. 81)

Martinho, a partir desse primeiro contato com Leonor, passa a trabalhar para ela e para o Dr. Cristiano Fradique, como se tivesse em mãos dois destinos, duas personagens, que não o pertencem, pois são resultado de um "homem do mundo". Venâncio não tem em mãos aqui somente o futuro e a criação dessas personagens, tem também toda a produção literária feita sobre Fradique Mendes à sua disposição.

É ao mesmo tempo crítico literário, literato e pesquisador. Parece montar um quebra cabeça, mas este seria diferente, as peças não têm formatos definitivos, como se tivesse de haver um número exato de peças em uma forma exata, mas os encaixes são mutáveis e delineados no momento do encaixe. Assim faz Fernando Venâncio em seu ensaio, em seu romance, em sua crítica.

O crítico e ensaísta Martinho aparece em todo momento da obra, quando está diante dos trabalhos que analisa, de tudo aquilo que fora escrito sobre o personagem. Um exemplo consistente está no Capítulo 16, quando contrapõe a obra de Antonio Sardinha e a obra de Perry Vidal, que entram em discordância em relação a uma data - falecimento de madame Lobriska e ida de Carlos (filho) para Portugal.

E ainda sobre esse papel de crítico de literatura, o narrador chega a discutir uma possível falta de amadurecimento literário na obra de Perry Vidal e aproveita para ironicamente dar uma satisfação para tal falta de qualidade literária: "Eu bem sei. Frederico Vidal redige "O único filho de Fradique Mendes" com a inacreditável idade de quinze anos, e vê-o publicado, em 1950, em Lisboa, aos dezesseis" (Ibidem, pág. 85).

E quando trata do ambiente conservador e também estilo conservador da escrita do autor (Vidal) tenta buscar motivos para a não existência de alguma passagem no livro que explicasse a 
origem de Leonor, por exemplo alguma paixão que tenha tido o príncipe de Palidoff. Mas isso não é problema para as conjecturas de Martinho (ou de Venâncio).

Partindo de uma crítica literária, tendo elementos dessa crítica como "desculpas" para aquilo que não aparece na obra, Martinho cria, conjectura uma relação amorosa (ou seja, reformula um encaixe naquele quebra cabeça mutável) para que assim possa aparecer Dona Leonor. “Ainda não sei que pensa dona Leonor deste livro, que lhe ignora a mãe e, ao fazê-lo, lhe renega a própria existência. Imagino que não dará graças.” (Ibidem, pág. 85).

Fradique Mendes sempre fora pintado com cores de conquistador e mulherengo, desde a excêntrica aparição em $O$ Mistério da Estrada de Sintra. Parece-nos que Venâncio coloca isso em prática exteriorizando definitivamente este ponto, quando começa a montar esse quebra cabeça em que há a figura de Ana Olímpia - que gerou Cristiano - e a figura de Varia Lobriska - que gerou Leonor. Além dessa constatação, há uma afirmação no início do capítulo 16 que mostra essa veia Don Juan de nosso personagem: "Tinha o sábio terceirense cinquenta e quatro anos, ou ia fazê-los, e deixava tristes [quando finou] Portugal, o Mundo e três ou quatro mulheres.” (Ibidem, pág. 83).

O Capítulo 17 inicia com uma comparação que nos parece pertinente comentar. Parece Martinho, inebriado pela figura de Fradique Mendes e por tudo aquilo que ela tem lhe proporcionado, se comparar com um dos efabuladores mais importantes em todo esse processo analisado pelo próprio Martinho:

O fato é que estou, nesse momento, mais fascinado pelo Fradique do que pela Tânia, e ela percebe-o. Tal como o percebia, há cem anos, Maria Emília de Castro, que, de Paris, viu Eça de Queirós ficando tempos infindáveis por Lisboa, mais ocupado com o amigo do que com a esposa. Curiosa história: Carlos Fradique Mendes é hoje, pela segunda vez, pretexto dos ciúmes de uma mulher. (Ibidem, pág. 87)

Comparar-se com Eça de Queiroz parece-nos propositalmente querer se aproximar da figura do principal efabulador; ou seja, seria como se auto afirmar um dos jogadores. É também Venâncio, já que traz um ensaio e uma crítica, além da produção literária, também a discussão metalinguística. Se os outros efabuladores trabalharam a questão de se discutir a própria produção das cartas, como faz Eça, em carta a um amigo editor de jornal, Venâncio vai além e coloca em discussão a própria questão das efabulações, de se produzir abertamente uma narrativa em cima de outra narrativa e assim progressivamente discuti-las.

No capítulo 18 gera-se outra expectativa como aquela que falávamos anteriormente. Se Cristiano apresenta espólio fradiquiano, Leonor também o faz, traz uma réplica do cofre espanhol, em que Fradique guardava os papeis mais valiosos; e afirma a Martinho que um dia ele colocará os olhos em tais documentos. Mais um espólio, mais possibilidade de criação. Mas aqui mais uma vez 
o quebra cabeça precisa ser reformulado: "É que os papéis russos que a neta de Fradique me promete são, historicamente, uma impossibilidade. Eles existiram um dia [...] Imaginá-los sobrevivendo a [...] dois incêndios, é entregar-se uma pessoa, de olhos abertos, à loucura." (Ibidem, pág. 95). - incêndios contados por Antonio Sardinha e por Perry Vidal.

Venâncio é de uma articulação narrativa bastante astuciosa para escapar de supostos problemas nesse jogo. De fato houve dois incêndios, um relatado por Sardinha, quando da revolução francesa, camponeses invadiram o palácio dos Palidorff e o incendiaram e o segundo quando da vontade do próprio príncipe de Palidorff queimar o recheio do cofre.

$\mathrm{O}$ autor encontra uma esperança para que algo dessa imensa produção pudesse ser salva, e ainda se aproveita disso para injetar algum elemento, alguma problemática (conflito) em sua própria teia narrativa, encaixando o personagem Baltasar Touriga definitivamente na narrativa.

Mas até a desesperança precisa de limites. Um cenário paralelo às duas carbonizações permitiu - terá permitido - a uma parte do espólio original salvar-se, para perdurar alhures, e mais exatamente nos perdidos, e achados, dossiês do dr. Cristiano Fradique. A hipótese é, todavia, assustadora, pois tudo autoriza a supor que uma cópia deles se encontra, desde há dois meses, nas gavetas dos gatunos da edição crítica. Ou na casa forte dos seus bancos. Ou, passada a scanner, digitalizada para a eternidade, no medonho bojo dos seus computadores. [...] Para dizer tudo: quem ao fim e ao cabo merecia, quem sempre mereceu ter nas mãos tamanho tesouro, foi esse camelo do Baltasar Touriga, que, mesmo no calabouço, deve andar-se dia e noite, a engasgar de risos. (Ibidem, págs. 96-7)

Além de ajustar o quebra cabeça, alimenta sua narrativa impondo ao personagempesquisador-crítico-literato uma ideia fixa, um objetivo no enredo, tomar contato com tais espólios. Astuciosamente Venâncio cria sua malha e cobre as linhas, ou frações, narrativas dos efabuladores.

No capítulo 21, ainda dentro da parte que cabe à discussão sobre Leonor, o narrador reflete sobre seu papel nessa teia narrativa:

Eu estou de posse de conhecimentos que totalmente lhe escapam [ao dr. Fradique], sendo eles o mais relevante a genealogia paralela que desembocou em dona Leonor. Cristiano ignora a existência duma prima direta. Um encontro dos dois, por Leonor ardentemente desejado, seria um episódio irrecusavelmente histórico, dependendo agora de mim, e só de mim, ter ele lugar. (Ibidem, pág. 103).

"Estar de posse" aqui vai além de simplesmente possuir um objeto. O narrador se dá conta que possui personagens e elabora suas trajetórias. Seria como o reconhecimento do poder da criação. O narrador estuda a possibilidade de uma união entre esses dois galhos genealógicos.

Levando em consideração aquele quebra-cabeça mutável de que falamos, o encontro dessas personagens de fato representaria um encaixe perfeito do conjunto de peças. Enredaria um conjunto de linhas narrativas muito bem construídas e, se não finalizada, pelo menos com uma delimitação 
perceptível. A narrativa vai ser levada astuciosamente pelas conjecturas de Martinho para que definitivamente esse encontro aconteça e faça parte da história portuguesa.

A partir desse ponto do romance, quando Martinho percebe o poder narrativo que tem, passa a construir, de maneira mais intensa, ficção sobre a trajetória de Fradique e de seus descendentes. Parece perder o receio de produzir literatura. Parece se colocar como autor, mesmo ainda, e até o final do romance, sendo um jornalista e um crítico.

Ainda nesse capítulo, quando Martinho fala sobre as trajetórias das personagens, e principalmente o encontro dos dois primos, há a seguinte frase: "Porque não deixo eu, portanto, o Mundo como estava, antes de eu me ter posto a importuná-lo? Que sou eu?” (Ibidem, pág. 105). Podemos estender essa pergunta de Martinho (que ficcionaliza a vida de Fradique e de seus descendentes) para todos os efabuladores de Fradique Mendes. Criar Fradique, efabular com ele não é definitivamente deixar o mundo como está. Essa afirmação é chave para todo o jogo, pois aqui temos o que podemos dizer como uma das regras principais do jogo: efabular Fradique é tentar modificar um status quo, já que juntamente com ele vem um forte poder de crítica.

Eça e os amigos certamente criaram Fradique com a finalidade de fazer uma crítica à sociedade da época, e o fizeram. Agualusa certamente traz um Fradique que tem por objetivo desmitificar uma África estereotipada e Venâncio, um personagem que é mote para uma crítica a um Portugal do século XX e também para uma nova maneira de construção textual, a experimentação, a crítica à crítica e o romance com características de ensaio.

No final do vigésimo segundo capítulo há o contato de Martinho com o possível espólio de Fradique. Interessa-nos perceber o estado dos documentos:

Ergui a tampa. Olhei. Eram papéis, arrumados, sem dobras. Apanhei alguns, vi serem fotocópias. Sentei-me num gênero de canapé, tentando enxergar melhor. Mas não conseguia, a letra era miúda, de alguma irregularidade, muito apagada, e a luz insuficiente. Retirei outro maço. A mesma coisa. Havia umas datas. 8 de abril de 1876, 27 de agosto de 1882 (isto invento eu agora, podia ser outro ano, e decerto outro dia). Tratava-se, tudo o indicava, de um diário. Procurei a proximidade da luz, mas isso fazia o texto ainda mais difuso. Como uma cópia duma cópia. Ou até mesmo, lembro-me de ter pensado, um print dum scanner. (Ibidem, pág. 111)

Ver o conteúdo do baú de Fradique era para Martinho entrar na essência da personagem, e o estado das coisas, a nosso ver, realmente reflete esse essencial fradiquiano, levando em consideração, obviamente, tudo aquilo que temos trabalhado sobre a personagem.

Fradique parece-nos ser papel arrumado, sobreposto, sem dobras. Composto às letras miúdas, difusamente cópia da cópia. Personagem escaneado, um print daquilo que se propôs desde o início. Cópias rabiscadas com conjecturas (“isto invento eu agora”). Camadas que provém de um original, sobrepostas, mas que compõe uma unidade coerente. Quando aparentemente parece 
escapar, algum efabulador (como no caso de Venâncio) resolve rearranjar os encaixes das peças (das cópias), sem deixar dobras.

No capítulo 24, Martinho, deambulando - para usar suas próprias palavras - reflete sobre a possibilidade de estar louco. Tratar de Fradique, assim como trata Venâncio, dando a personagem categoria de realidade, faz com que o limiar entre a realidade e a ficção seja ainda mais tênue. Não se trata aqui de entrar no ficcional ou viver a realidade, trata-se de contrapor ambos, ou até mesmo misturá-las (é isso que faz Martinho).

Portanto, estar nessa transição, ou interseção entre realidade e ficção pode ser de fato estar entre a realidade e a loucura. Pois Martinho (mesmo sendo personagem de ficção) vive um Portugal real, histórico, mas está também na paralela fradiquiana (ficcional - intensificada pelo primo de Tânia). Podemos falar então em criar uma outra paralela, uma outra perspectiva, que não condiz com a realidade e muito menos com aquilo que é totalmente ficcional. Como dito, é estar entre a loucura e a realidade, mas de maneira lúcida e consciente.

A partir do capítulo 25, cria-se uma grande expectativa pelo encontro de Leonor (fração de Perry Vidal) e Cristiano (fração de Agualusa). Enquanto disserta sobre aquilo que um tem como prova de que é mesmo descendente de Fradique Mendes, e o que o outro pode apresentar também como prova, começa a desarticular sua própria teia, seus próprios levantamentos sobre o diário encontrado, sobre a veracidade da árvore genealógica de Leonor e Cristiano.

O jornalista discutia sobre as possíveis provas que um deveria dar ao outro (Leonor a Cristiano e vice-versa):

Só na lista telefônica de Lisboa já uma dúzia de Fradiques. E os Mendes enchem cinco cerradas páginas. De resto, se fôssemos a coisas, nem a própria posse daquele diário, ou de quaisquer outros escritos atribuíveis a Carlos Fradique Mendes, seria concluinte. Mais ainda: a concentração de tais espécies nas mãos do dr. Cristiano seria, também, a sua fraqueza probatória. "Alguém" escreveu aquilo, dando a si mesmo o nome que sabemos. Mas por que havia tudo isso de ser autêntico? Enfim, uma coisa me parece agora de todo clara: se estes dois não desejarem ser primos, ninguém os fará primos. (Ibidem, pág. 130)

Parece-nos que Martinho aqui desconstrói seu monumento fradiquiano, negando sua busca por provas, o que fazia com que essa trama genealógica fosse bem construída. De fato só parece que o faz; na realidade há um movimento de aparente negação para posteriormente dar plenos poderes e até mesmo reforçar o seu próprio papel de efabulador, e também aplicar a essas personagens plenos poderes de desejos, como se não mais fizessem parte de uma efabulação.

Venâncio e todos os outros efabuladores têm certamente plenos poderes em suas criações (respeitando as regras do jogo), Venâncio é o que mais mostra e se aproveita disso, já que elabora encaixes daquilo que já foi promovido com a personagem. 
Leonor e Cristiano são primos e se reconhecerão como tais porque é simplesmente a vontade de um efabulador. Logo, aqui (e em outros momentos da obra venanciana) vê-se a preocupação do papel daquele que cria e sua importância para que esse jogo se estabeleça. Esse poder é transmitido a uma vontade de personagens que já se estabeleceram no âmbito da realidade, tamanha sua força e coerência, proporcionadas por uma trajetória narrativa secular.

No vigésimo nono capítulo de Esquemas de Fradique, Baltazar (aqui já Martinho tinha descoberto que o nome era com “z”) entra em contato por e-mail (hotmail) com Martinho. Nele expõe um plano para uma edição completa de A Correspondência, com um apêndice inédito, um diário de viagem por Carlos Fradique Mendes.

Além de esse contato servir de fato para dar mais um mote ou conflito à narrativa, serve também, para nós, como metáfora do "tornar conhecido à história" mais uma fração de Fradique. Assim como Perry Vidal, Agualusa, Eça (entre outros não contemplados) a publicação dessa edição completa, mais o Diário de Viagem por Carlos Fradique Mendes, traria à tona algo mais sobre o "homem do século", e nunca seria o suficiente, um manuscrito que no capítulo 33 chega definitivamente às mãos de Martinho. E nada dele é publicado até a saída de Balto da cadeia e a finalização do romance, mas há a inclinação de Martinho pela publicação da obra completa. Essa publicação passa a ser possível somente pelas mãos de Martinho, pois ele é quem tem o contato com Leonor (e seu espólio fradiquiano) e com Cristiano (e seu espólio). Logo, ele é a ponte para que algo novo do Fradique possa vir à tona. E no capítulo 32 ele toma consciência disso: "Sou já, a meu modo, um guarda do espólio" (Ibidem, pág. 162).

Parece-nos que a figura de um narrador que conjectura vai, durante todo o romance, numa ascendente de sua consciência como criador (que elabora) e como aquele que projeta uma trajetória nova para a personagem. De um jornalista perdido a um homem certo de seu poder de criação e investigação (embora durante todo o texto ele mesmo não saiba qual é o limite entre a história e a ficção).

Essa consciência do poder que tem em mãos é evidenciada no capítulo 34, quando fala sobre o conteúdo do espólio fradiquiano (cópias e originais, que estão em poder de Cristiano e Leonor): "O neto imagina ali o desenfado de um diarista, o recluso vê um pornógrafo à solta, e a neta juraria pela inocência do avozinho. É a eles, todos três, que eu me preparo para roubar as ilusões" (Ibidem, pág. 132). A interpretação de Martinho em relação aos manuscritos é de fato preponderante para o processo e a trajetória dessa narrativa. Evidente que é nessa efabulação que o foco parece, por vezes, sair do personagem e se inclinar para a figura do efabulador (metaforizado em Martinho). A figura de quem cria, a questão do processo de criação (realidade versus ficção) os agentes que interferem nessa criação parecem ser, muitas vezes, primeiro plano na obra, o que não acontece em outras efabulações. 
Fica claro que aqui se trata de um processo de efabulação, e não de simulação. Ou seja, não se trata de simular cartas de Fradique, se trata de exatamente discutir a trajetória tendo como base tais documentos, e nisso discutir o próprio papel do efabulador, mesclando com um novo processo de criação (o arranjo do quebra cabeça).

Por volta do capítulo 36, Martinho, segundo informação do Dr. Godinho (informações à boca pequena), começa a investigar um episódio da vida de Fradique: ele seria um espião ao serviço do rei Dom Luis, investigaria investidas contra o reinado português. Martinho tenta elaborar, com base nas informações de Godinho e com base nos manuscritos de Leonor e Cristiano uma trajetória plausível para tal hipótese. Aqui mais uma vez uma tentativa de ajuste do quebra cabeças. Mais do que isso, tentar colocar Fradique Mendes a serviço do Rei é de fato tirá-lo do boulevard e colocá-lo em um papel de importância e até mesmo pitá-lo como um herói. Em visita a Leonor: "Mostrar-lhe os esquemas recheados de coordenadas, que pelos meus cálculos caíam sempre em Moçambique e em Angola, ou então na Inglaterra ou na Alemanha, os dois salteadores à espreita da África Portuguesa?" (Ibidem, pág. 178). Tenta encaixar as peças, tentando levantar a hipótese da ida de Fradique à África pelo motivo dos serviços que prestava ao Rei.

Vemos então a tentativa de fazer com que essa personagem ganhe ares heroicos, de efetivo serviço ao Império. De fato seria fazer com que Fradique Mendes fizesse as pazes com Portugal (o que será levantado mais adiante).

No capítulo 36 há uma nova informação importante: Martinho descobre entre as fotocópias duas ou três páginas de originais. Deles transcreve pela primeira vez trechos do diário de Fradique:

As últimas noites têm passado em branco. Só de manhã me permito adormecer. Olho o gás mortiço, inspeciono a sombra das árvores. Depois levanto-me, desço, vou verificar os ferrolhos. Volto ao quarto, e é de novo a observação das árvores, das esquinas, dos recantos. Que se passa comigo? Que fantasmas arranjei, que não me largam, nem dão o prazer de acabarem vistos? [...] (Ibidem, pág. 182)

Martinho apresenta um Fradique estranho à primeira vista. Com medo de algo, de fantasmas talvez. Levanta-se aqui mais uma expectativa (típica do romance) - haveria ali uma outra fração fradiquiana? Isso inebria Martinho, que passa horas na madrugada lendo esse desconhecido Fradique Mendes. E no final do mesmo capítulo, parece conjecturar com base nesse documento as reações dessa noite fatídica para Fradique Mendes. Mais uma vez realidade e ficção se misturam.

No capítulo 37 podemos perceber que Martinho começa a "decifrar" aquilo que de mais importante poderia haver em um Fradique Mendes. Além de buscar toda a trajetória dessa personagem, tentar ajustar o que aparentemente seria incoerente (é o faz), prepara para seu livro um grand finale: "Doutor Fradique [...] os diários do seu avô são relatórios, escritos em código, que 
foram sendo enviados, evidentemente passados a limpo, a gente importante do Continente” (Ibidem, pág. 191).

Como dito, a percepção para com essa personagem, principalmente para o leitor que conhece toda a sua trajetória, se modifica. Como se o próprio leitor pudesse reposicionar, reclassificar, recondicionar, reelaborar esse Fradique Mendes deambulador. Talvez a ida a África tenha tido realmente uma motivação investigativa (espiã). Parece que todo caminho de um Fradique agualusiano é reconfigurado após a descoberta de Martinho.

De flâneur a herói: “A edição crítica de 'Correspondência de Fradique Mendes' de Baltazar Touriga haveria de dar conta dessa face tão bem escondida, no nosso herói” (Ibidem, pág. 193). Parece querer tornar pública definitivamente essa nova perspectiva que se tem de Fradique Mendes.

Martinho e Cristiano, no capítulo 38, começam a conjecturar sobre a verdadeira morte de Fradique, tendo em vista essa nova visão. Martinho diz ser mentirosa a causa de morte (pneumonia) levantada pelo biógrafo Eça de Queiroz (por piedade - talvez este conhecesse as verdadeiras atribuições de seu amigo Fradique). Levantam qual seria a verdadeira causa da morte: um crime perfeito, engendrado por Rattazzi:

Carlos Fradique Mendes foi assassinado por ter servido um rei. Por quem? Nunca, provavelmente, o saberemos. Pelos ingleses? Pelos alemães? Por algum concorrente? A Rattazzi? Um diplomara português? Resta-nos especular, o que sempre desenvolve, dizem, a mente. (Ibidem, pag. 196)

Parece-nos criar uma trama mais complexa, misteriosa e profunda do que tudo aquilo que fora criado sobre Fradique. Pois levantar que aquilo que Fradique descreve são códigos "para alguém importante do Continente" pode ser o mesmo que dizer, "tudo o que Fradique produziu pode não ser aquilo que está deverás escrito!".

Podemos entender isso como uma forma de criticar a própria criação e dar ao papel do criador (efabulador) uma importância sem igual, pois uma nova visão da personagem, implicada por um de seus últimos efabuladores, pode ter a capacidade de reformular tudo aquilo que fora feito (e não é pouca coisa). Por isso afirmamos que aqui essa narrativa se torna mais maleável, pois ter como centro a discussão sobre o processo de efabular e o efabulador é de fato abrir margem para a criação e para a modificação daquilo que foi criado.

Simplesmente eu tinha chegado mais longe do que ele [Cristiano] imaginava poder chegar-se. Eu vinha com nomes, o de Batalha Reis, o de Enes, o de Cordeiro, porque quem fosse o "Luís" já ele pressentia. Eu decifrara as coordenadas dos esquemas, eu sinalizara a monotonia, e, portanto, o caráter codificado, das encenações eróticas. (Ibidem, pág. 195) 
No capítulo 42 há efetivamente o plano de tornar presentes no mesmo ambiente os dois descendentes de Fradique Mendes: "Eu iria de táxi apanhar a Leonor a casa, e partiríamos justos a Gago Coutinho. Aí se daria, comigo como testemunha e grato espectador, o encontro dos dois netos de Carlos Fradique Mendes.” (Ibidem, pág. 215). E já aqui vemos que há uma preparação para a finalização da obra, quando os dois descendentes se encontrariam na noite de comemoração da Revolução dos Cravos, aniversário de 25 anos. Dr. Cristiano chegaria em casa por volta das 19 hs, Martinho pegaria Leonor por volta das $21 \mathrm{hs,} \mathrm{antes} \mathrm{disso} \mathrm{o} \mathrm{jornalista} \mathrm{iria} \mathrm{receber} \mathrm{seu} \mathrm{amigo}$ (gatuno) Balto ao sair da prisão, o que seria na parte da tarde, mas logo Martinho recebe uma mensagem que dizia ser à noite. Como não se pode estar em dois lugares ao mesmo tempo, o jornalista entra em um dilema, receber o amigo que sai da cadeia ou ser testemunha ocular do encontro histórico? Tenta, em um movimento narrativo intenso (epifania) fazer todos eles. No caminho à sua jornada contra o tempo reflete sobre a importância desse encontro, e se coloca como "escrivão da história":

Aquilo que ali se preparava era a História, com um $\mathrm{H}$ imenso, e, dela, eu era só o casual escrivão. E tinha graça. Porque quem diz escrivão, diz cronista, diz jornalista. Não havia, portanto, em tudo isto que eu empreendera um primoroso exercício da minha profissão?" (Ibidem, pág. 220)

Martinho tensamente aguarda a saída de Balto e encontra uma maneira para que os primos se encontrem sem, inicialmente, sua presença - “[...] Olha, toma um táxi, e vai já para o teu primo." (Ibidem, pág. 222). Às 21 e 30 Balto sai da cadeia e contra, emocionalmente, Martinho, se abraçam como se reconhecessem. Saem da cadeia e Martinho vai em velocidade para o encontro dos descendentes, nisso já começam as comemorações de 25 de abril.

Chegam até a casa de Cristiano, não entram, Martinho e Balto observam de fora algumas nuances dos corpos dentro, os gestos, o vestido de Leonor, os cálices de vinho do porto (supunham). Ao observarem este encontro histórico, Martinho Telha e Baltazar Touriga discutem sobre e veracidade daquele encontro. De forma lírica, em plena comemoração da Revolução dos Cravos (data em que Portugal faz as pazes com ele mesmo), presenciam o que, para ambos, seria o acontecimento do século.

"Baltazar", disse eu, assim que reuni os pensamentos, "tu acreditas em fantasmas?". Olhou-me. Não sei se me via. "Eles existem?", disse ele. Olhei-o. Vi um rosto miúdo perto do meu. "Talvez. Aqueles dois, em todo caso, sabem agora a resposta. Estarão é a perguntar-se se eles próprios existem.” Ajuntei logo: "Olha-os bem. E vamos embora, pazinho, antes que eles desapareçam”. (Ibidem, pág. 228) 
Confundem-se realidade e ficção no final da obra de Fernando Venâncio: aquilo que já vem trabalhando durante o texto é evidenciado em seu final de forma lírica, pois é um fato que ocorre juntamente com a comemoração de um quarto de século da Revolução dos Cravos.

Mas diferentemente do que se percebia, as personagens aqui parecem realmente fazer parte de uma história, pois não há mais a intromissão ou a criação de seu investigador (Martinho). As personagens parecem "andar com as próprias pernas", ganhar definitivamente vida, como se a partir de um momento o efabulador não pudesse mais interferir na trajetória da personagem, o que dá também certo lirismo ao grand finale venanciano. 


\section{2 - INTERSECÇÔES FRADIQUIANAS}

Gerar Genette, em Parlimpsestos (Genette. 2006), traz categorias que são pertinentes para podermos entender teoricamente como se dão os níveis de interação textual (intertextualidade) em todo o processo de formação de Fradique Mendes, no tocante aos diferentes textos em que essa personagem é figura central, e que colaboram para a construção, segundo o que acreditamos, de uma biografia única.

Genette afirma: "Um texto pode sempre ler outro, e assim por diante, até o fim dos textos. Este meu texto não escapa à regra: ele a expõe e se expõe a ela. Quem lê por último lê melhor." (Genette. 2006. Pág. 6). Se apropriando de um ditado popular - e colocando ludicamente já o seu objeto, o intertexto - Genette afirma ler melhor, entender melhor aquele que tem contato com o último texto. De fato essa máxima (re)criada pelo autor de Parlimpsestos cabe perfeitamente em todo o processo de criação de Fradique Mendes, desde o romance Os mistérios da Estrada de Sintra, até o romance de Fernando Venâncio - o que propomos estudar.

Um texto, como dito, vai crescendo em camada por sobre o outro. Um texto se espelha no outro se aproveitando de manchas deixadas pelo primeiro. Foi o que fizemos durante a dissertação. Mostramos que um único Fradique vai crescendo em frações até ser apresentado um Fradique com uma biografia mais completa em Fernando Venâncio.

Logo, quem tem acesso ao texto Esquemas de Fradique, tem também acesso aos textos de outros efabuladores, por conta também de se tratar de uma obra de caráter ensaístico. Mas é possível ter uma ideia da completude de Fradique lendo somente Venâncio? Não.

De fato o jogo se estabelece para que o leitor busque todas as frações do personagem. Temse a ideia de um Fradique aos olhos do ensaísta e literato Martinho, outro aos olhos de Agualusa, outros aos olhos de Perry Vidal, e assim por diante, mesmo que todos eles montem um todo chamado Fradique Mendes.

Venâncio parece deixar claro esse propósito da completude. Traz um texto de pesquisa literária para tentar montar, ou (re)montar, ou transpor, ou traduzir um personagem que já vem sendo montado no decorrer da história literária portuguesa e angolana.

O processo de criação de Fradique Mendes, entendemos, é a materialização do que Genette afirma ser a Transcendência Textual: "Eu diria hoje, mais amplamente, que esse objeto é a transtextualidade, ou transcendência textual do texto, que definiria já, grosso modo, como "tudo que o coloca em relação, manifesta ou secreta, com outros textos”. (Genette. 2006, pág.7)

O autor elenca cinco tipos de relações transtextuais: a intertextualidade: que seria a presença efetiva de um texto em outro, como por exemplo da prática da citação (com aspas) ou plágio, um "empréstimo não declarado" ou ainda a alusão, que seria um trecho que supõe diretamente outro 
texto.

Em segundo há o paratexto: uma relação menos explícita e mais distante entre os textos. Exemplos: Título, subtítulo, intertítulo, prefácios, posfácio, advertências, prólogos, notas marginais, de rodapé, de fim de texto, epígrafes, ilustrações, errata, orelha, capa, autógrafos, alógrafos, que oferecem um aparato que pode se remeter a outros textos.

Um terceiro tipo é a meta textualidade, que consiste em um "comentário", ou seja, une um texto a outro sem necessariamente citá-lo, ou até mesmo sem nomeá-lo. Trata-se de efetivamente a crítica.

O outro tipo de transtextualidade é a arquitextualidade, o mais abstrato e implícito, está em um âmbito taxonômico, uma relação "silenciosa", exemplifica-se em uma menção paratextual (título, subtítulo...) ou infra titular, como Romance, Poesia.

Por fim, o último tipo de transtextualidade, para Genette, é a hipertextualidade: "toda relação que une um texto B (que chamarei hipertexto) a um texto anterior A (que, naturalmente, chamarei hipotexto) do qual ele brota, de uma forma que não a do comentário" (pág. 12).

Genette disserta também sobre o conceito de "Transposição", que se consiste em uma prática transtextual de textos longos que acaba por apagar ou mascarar o hipotexto, dando ao hiper um caráter amplo e original, diferentemente do que Genette levanta como Paródia: transformação obvia e explícita em que o hipo e o hipertexto se caracterizam como textos breves, em que a relação transtextual é clara:

A transposição, ao contrário, pode se aplicar a obras de vastas dimensões, como Fausto e Ulisses, suja amplitude e a ambição estética e/ou ideológica chegam a mascarar ou apagar seu caráter hipertextual, e esta produtividade está ligada, ela própria, à diversidade dos procedimentos transformacionais com que ela opera. (Genette, pág. 28)

Sem dúvida que Genette encontraria substrato suficiente para seus estudos, e inúmeros exemplos, em todo o processo de construção da personagem Fradique Mendes. Todas as categorias levantadas pelo autor estão presentes nesse processo. Esses processos são explícitos na obra de Venâncio, também por se tratar de um romance com características ensaísticas. O autor se utiliza da prática da citação, o que seria pra Genette um dos elementos que marcam a intertextualidade.

O que Genette classifica como paratexto é também observado nesse jogo, principalmente na relação entre os títulos. As obras aqui trabalhadas trazem sempre a alusão textual de que é produto da leitura de outro texto, como $O$ único filho de Fradique Mendes (que irá nos remeter diretamente a obra de Queiroz), também em Correspondência secreta de Fradique Mendes (subtítulo de Nação Crioula) e em Esquemas de Fradique. Parece-nos que esses paratextos estão diretamente ligados ao livro original de Eça de Queiroz. 
Venâncio trabalha a metatextualidade conceituada por Genette, pois também como crítico, Fernando Venâncio, na voz de Martinho, faz alusão e comentários sobre todo o processo de efabulação fradiquiana. Como crítico e pesquisador vai atrás do fato (mesmo ficcional) para comprovar as idas e vindas de seu objeto, a vida pregressa de Fradique Mendes.

A arquitextualidade pode ser observada, por exemplo, pelo gênero utilizado na construção dessa personagem; não estamos dizendo que todos os efabuladores se utilizaram de um mesmo gênero para compor seu texto, até porque isso não acontece. O que afirmamos é que essa personagem está presa a um gênero no sentido de que quando ganha voz é por meio de cartas, e quando essa personagem é rememorada, investiga-se a produção de suas cartas. Fradique se deixa conhecer somente por esse gênero e quem quiser investigar sobre a passagem do homem do século pela terra terá que mergulhar nas epístolas deste homem.

E todo esse jogo fradiquiano tem como base o que Genette levanta como Hipertextualidade, o que corrobora com nossa teoria das camadas. Pois o texto que impulsiona a produção de Vidal é o de Queiroz, logo, este seria hipotexto do segundo, que seria o hipertexto. Já estes dois funcionariam como hipotexto de um terceiro (Agualusa), e esses três funcionariam como hipotexto do último que nos propomos a estudar, que é o de Fernando Venâncio, a nossa camada superior.

Além da transtextualidade no processo, defendemos certa coerência nas características da personagem, que faz com que se monte aos poucos uma biografia (incompleta). Aqui também levantaremos traços em comum na constituição desse Fradique Mendes. Embora pareça prolixo, vamos rapidamente elencar algumas passagens, de maneira mais categórica, sobre elementos que marcam essas efabulações.

Iniciaremos pelo "homem de causas", já que posição política é de fato uma vertente que une todas as frações fradiquianas. O texto crítico faz de fato parte desse ser. E por isso, acreditamos, fora escolhido para tantos propósitos diferentes, mas sempre com uma vertente ácida e crítica. Em Os Mistérios há um poeta excêntrico e representante de uma geração aguda, uma nova geração poética (por isso comparado a Victor Hugo e Charles Baudelaire). Em A Correspondência, como visto um momento de efetiva criação biográfica, temos uma personagem que faz várias críticas políticas em relação ao seu lugar (um deles). Publica no jornal 18 de setembro, importante periódico lusitano. É ainda nessa obra comparado com os mais importantes poetas, que tinham uma visão de mundo diferenciada e também crítica.

Este Fradique chega, como visto, a levantar um manifesto à prosa realista, menosprezando todo e qualquer sentimento romântico de idealização e sentimentalismo - lembramos que as cartas a Clara são puro jogo de retórica.

Em A Correspondência ainda vemos um Fradique militante de uma seita, quando em uma de suas viagens passa a integrar uma das culturas em que visitou (1.2). Há ainda, em carta a Calor 
Mayer uma discussão ácida sobre o papel do cânone literário, sua importância na formação intelectual e sua relatividade (o que mais nos chama a atenção).

Neste mesmo movimento de crítica, temos em Nação crioula não a quebra de um cânone literário, mas a quebra de algo que socialmente pode ser maior. A quebra de um estereótipo africano (proposta agualusiana). Somente um homem de coragem e visão crítica teria a capacidade de mostrar uma África lírica e sem os estereótipos que um homem de metrópole, no século XIX, teria.

Critica, com base na experiência, todo o processo que estimula um estado das coisas na sociedade do final do século XIX, principalmente no tocante ao tráfico negreiro.

Embora seja a imagem da modernização, vimos que há em Fradique algo chamado ponderação. Exemplo em carta para o amigo Bertrand (engenheiro), quando relativiza a questão da modernidade: há lugares que não dependem da modernidade ocidental. Representante do moderno, mas que, pertinentemente, às vezes o nega, o pondera.

A veia política é descoberta no final da obra de Venâncio, quando Martinho conjectura que o "homem do século" fora um espião a serviço da coroa portuguesa, defendendo as causas políticas e trabalhando para que o império lusitano não perdesse lugar na África (possível motivo pelo qual fora à África pelas mãos de Agualusa).

Percebemos que em todas as efabulações (mesmo que depois faça as pazes com o lugar de origem) mantem-se uma relação bastante estreita com Portugal, vezes comparando-a com personagens que poderiam metaforizar o atraso e a estagnação (caso de Pacheco em $A$ Correspondência) e vezes, contraditoriamente, trazendo a imagem lírica da Revolução dos Cravos (Venâncio). Podemos dizer que há um movimento pendular de distanciamento e aproximação.

Ainda no âmbito político, Fradique é dono de uma retórica bastante elaborada em todas as efabulações. Fradique carrega o dom da palavra e sabe de sua importância, pois em alguns momentos temos elementos metalinguísticos nas obras, quando discute o poder da mídia (Carta a Bento de S. Em A Correspondência) ou porque não escreve um artigo para a revista de história.

Propriamente em Venâncio temos essa consciência do poder da palavra, no tocante às efabulação. Há um narrador, como dito em 3.1, que discute a própria produção literária, ou histórica, ou de crítica; enfim, temos em Esquemas de Fradique uma preocupação em discutir a produção da palavra.

E o fato de Fradique (lembramos que é um poeta) carregar esse poder da palavra faz (também) com que seus narradores se rendam a ele. Desde Os Mistérios temos um narrador que extrapola, a nosso ver, a personagem quando cria um tipo como Fradique Mendes. Em $A$ Correspondência temos um dos exemplos mais radicais disso. Um "Eça" que definitivamente se rende ao seu "amigo". Compara-o a deuses, aos mais importantes poetas (principalmente após ler Lapidárias). Um narrador que não tem coragem de interpelar o "homem do século", por mais de 
discorde dele. De fato em A Correspondência há um narrador que cai nas graças de Fradique Mendes.

Assim também acontece com o narrador de $O$ único filho, onisciente, que se utiliza de adjetivos de exaltação quando se refere ao que seria o único descendente de Fradique Mendes - o príncipe de Palidoff. Não só a ele, como visto em 2.1, mas também quando aparece um Fradique rememorado pela figura de Eça de Queiroz, que aparece no romance como um dos principais personagens.

Em Venâncio é onde vemos a maior rendição do narrador. Martinho Telha é levado pela linha narrativa de pesquisa. Como se trata de um pesquisador, passa a conhecer tudo aquilo que foi dito sobre Fradique, e quando percebe a força efabulatória dessa personagem, sente uma inevitável vontade de também efabular. É o que faz.

O jornalista Telha mergulha tão vertiginosamente nessa construção que tenta (e consegue) perceber e arrumar as incoerências do jogo. Reformula o quebra cabeças fradiquiano e ainda coloca seu personagem em uma instância mítica de herói português. A trajetória do narrador passa a acontecer por "vontade" do mito, na realidade paralela do mito.

Ainda no âmbito político, e em relação ao poder da palavra, Fradique, ou as palavras de Fradique, fazem sempre com que seu interlocutor reflita sobre algo. De fato não temos as cartas que voltam, ou seja, não temos as respostas, mas o remetente nos faz o favor, e isso é outra característica dessa retórica, de colocar, ou conjecturar as possíveis respostas de seus destinatários, como fez em carta do engenheiro Bertrand e como faz constantemente com madame de Jouarre. O contra-argumento é uma das armadilhas preferidas de Fradique Mendes. E os alvos principais são os políticos e o clero (que em Portugal se confundem em seus poderes e atribuições). Figuras de padres são constantes durante toda a trajetória de Fradique. Em A Correspondência há a crítica feroz a instituição católica (Carta a Guerra Junqueiro: “[...] para purificar esse catolicismo, eliminar o Padre [...] - pág. 162). Também ocorre, com certo movimento lúdico, em Nação Crioula, na figura de Padre Nicolau, que era milagreiro, erguia suas mãos para o Deus cristão mas tinha seus pés na feitiçaria e nos costumes de sua região. Há aqui uma relativização do que é e do papel do líder religioso.

Em Vidal há um movimento contrário a essa crítica, não sabemos se até mesmo pela posição religiosa do autor ou qualquer outro motivo. Mas Palidoff é exageradamente católico - vai a Roma pedir para que o papa reze pela nação lusitana. E como dissemos, enquanto seu pai frequentava o país da luxuria e do desapego, seu filho se enclausurava com medo da revolução.

Sobre a questão criatura e criador, levando aqui em consideração o primeiro efabulador, Eça de Queiroz, nos é claro que em todo o processo efabulatório, quem colocou as mãos nisso fez questão de aproximar criatura e criador. Talvez para fazer com que a obra ficasse mais creditável ou 
que esse "Eça" pudesse dar um aval póstumo para tudo aquilo que estava sendo feito.

Não sabemos, mas o fato é que Eça e Fradique nunca se separaram. Desde $A$ Correspondência, obra em que figuraram como grandes amigos; até Esquemas de Fradique, obra em que Martinho encontra pontes, contatos entre Eça e Fradique, há evidencias desse contato.

Em outra vertente, percebemos que Fradique traz em si a característica da excentricidade: já em Os Mistérios há um Fradique carregado dessa característica, quando em sua comparação com Charles Baudelaire, quando em seus versos e quando fala sobre sua relação animal com uma negra antropofágica.

O processo de excentricidade continua em A Correspondência, quando é comparado ao deus Júpiter, quando se coloca modesto e menospreza sua própria obra, quando discute o pronunciar correto das palavras estrangeiras com Madame S. e quando coloca em xeque a civilidade que Bertrand pretende levar ao Oriente, tratando com parcimônia a questão do civilizado-primitivo.

O príncipe de Palidoff parece trazer alguns traços dessa excentricidade paterna. Na sua própria figura (descrição do autor 2.1).

Agualusa promove um grau de excentricidade bastante singular. Principalmente tendo em vista a visão do colonizado. Ou seja, para o outro, geralmente subestimado, ver um Fradique Mendes é como ver algo que não se conhece. Isso já Agualusa nos mostra no início do romance quando da chegada de Fradique na África.

Neste lugar a figura de Fradique Mendes potencializa o "ser diferente". Há na verdade um jogo de diferenças (culturas). O homem da metrópole é a antítese do colono. Mas Agualusa monta uma narrativa em que essa diferença parece de diluir, e Fradique se africaniza, ou a África se modifica.

Sobre ainda a questão da excentricidade, há figuras singulares nessa obra, como Santamarina e o padre Nicolau. Este, um padre que é adepto aos feitiços e uma mulher que é horrível e ao mesmo tempo lírica aos olhares de Fradique. A África é de fato um lugar de antíteses e excentricidades.

Há elementos que se completam em Fradique, se há nele o dom da palavra, como dito, e esse poder de deixar seus interlocutores e narradores entregues a ele, tudo isso é de fato resultado de suas experiências, e isso é o que não falta na figura fradiquiana. É um homem de viagens e um contador de fatos.

Em Os Mistérios vemos em Fradique Mendes um homem de viagens. Quando conversa com a protagonista do romance fala sobre viagens, paradeiros dos mais exóticos, experiências de "ver pra crer". Mas ainda muito no âmbito do "estive", "fuii" etc.

Em A Correspondência temos um maior grau de empirismo, ou seja, as cartas podem comprovar os paradeiros, embora não sejam do Oriente, da América ou da África (e sim de lugares 
típicos de um flâneur) há a experiência do (e no) lugar. Já na parte biográfica da obra, "Eça" afirma que Fradique já conhecera a África Austral e o Oriente (1.2). Nela afirma que o poeta (talvez por ser poeta) tinha um olhar que ia além do senso comum (uma motivação para Agualusa). Havia uma sensibilidade singular em Fradique, pois quando conhecia uma nova cultura se inseria nela (mesmo que aqui ainda de maneira incipiente).

O grau de empirismo citado é elevado em Nação Crioula, pois é nessa obra que Fradique Mendes tem efetivamente contato com aquilo que não conhece e também passa a fazer parte efetiva de todo esse novo lugar. Não é um narrador que diz que Fradique conheceu lugares diferentes, as palavras são do próprio Fradique.

E em Esquemas de Fradique o homem aventureiro (também no sentido Don Juan) é evidenciado pelas pesquisas de Martinho Telha e por sua própria conjectura. Suas viagens à África, ao Oriente (Rússia), à América. Parece que na obra de Venâncio ele está definitivamente em todos os lugares que gradualmente esteve durante os outros textos. As viagens (e os possíveis e verdadeiros motivos delas) vêm à tona com um grau de complexidade bastante peculiar - reforçar as amarras e encaixar as peças (3.1).

As viagens de Fradique não têm somente uma proposta de evidenciar um homem de descobertas, a nosso ver, essas viagens também carregam um compromisso histórico, ou seja, parecem-nos viagens documentais. Agualusa mostra isso de maneira deliberada. Acreditamos que de todas as frações a mais documental é sem dúvida Nação Crioula (2.2).

Venâncio também trata disso, pois remonta a trajetória tendo em vista os lugares onde passou e, principalmente, como o faz no início, tenta intersecções entre Fradique e a história, quando, por exemplo, fala se seu contato com reis, príncipes, princesas e fatos históricos marcantes (3.1).

Um viajante que passa por lugares importantes e por épocas chave: crítica à política portuguesa em A Correspondência, a passagem da monarquia para a república em $O$ único filho, tráfico negreiro e relação colônia metrópole no séc. XIX, em Nação Crioula, Revolução dos Cravos em Esquemas de Fradique. E pessoas ilustres: José do Patrocínio em Nação Crioula, Olavo Bilac em $O$ Único Filho, Oliveira Martins em A correspondência, entre outros.

Em outra vertente, temos na maioria das efabulações um Fradique que tem uma relação peculiar com as mulheres. Inicialmente já em Os Mistérios, quando conversa com a protagonista do texto e diz sobre algumas experiências, tanto românticas como animalescas. Quando partimos do romance para o gênero epistolar, temos cartas a Clara, em A Correspondência (1.2). Uma mulher que deve se assemelhar àquele lago citado em Os Mistérios. Cartas românticas - com um tom falsificado da retórica - são apresentadas nesse heterônimo.

Em $O$ Último Filho há algumas poucas indicações de que o pai de Palidoff tivera uma ou 
duas aventuras amorosas, e isso era justificado pelo fato deste sempre ser pintado como viajante. Mas é em Nação Crioula, a nosso ver, que Fradique deixa de ser o Don Juan e passa a ser um homem definitivamente entregue ao sentimento de amor.

Diferente das cartas para Clara, para Ana Olímpia não percebemos aquela típica falsidade da conquista, são cartas viscerais e aparentemente honestas, como se o "herói" não tivesse de fato controle da situação, e em Nação Crioula (2.2) isso é uma constante, Fradique não tem controle das situações, não está no seu lugar (como se tivesse lugar) e tudo acontece em um movimento dinâmico e rápido, principalmente os amores.

Em Venâncio (3.1) parece-nos clara a tentativa de unir os pontos, logo, aqui temos uma mostra de todas as mulheres que passaram pela vida do janota, desde Clara até Ratazzi que, segundo Martinho Telha, teria arquitetado a morte do "espião a serviço da coroa".

Fradique vivia também para mulheres, o que prova sua capacidade de conquista e seu domínio com as palavras (sua retórica). Sempre haverá em algum lugar alguma mulher que tenha se relacionado com Fradique Mendes, aqui podemos enumerar algumas delas, como fizemos, mas haverá outras tantas que escaparam à pena dos efabuladores. E outras que virão.

Para finalizar, a última vertente que une essas frações fradiquiana é a questão dos espólios. Ou seja, aquilo que é deixado por Fradique e que se deixa conhecer pelos efabuladores.

Fradique carrega em si o mistério: não saber a vida inteira (nunca se saberá) de um viajante excêntrico e conquistador é de fato instigante para quem toma contato com essa personagem. Esse mistério é ainda mais potencializado quando há na malha narrativa a aparição de algum documento secreto (espólio). Seria como saber que há mais para se conhecer, criar uma expectativa, e não ter contato com esse "novo a conhecer".

Isso é tão singular em Fradique que em todas as efabulações há a menção de um espólio fradiquiano. E uma dessas efabulações (2.1) é montada com base em um espólio - Correspondência Secreta. Agualusa se utiliza de algo que não poderia vir à tona para elaborar um mote narrativo.

Depois daquilo que Eça escreveu tudo parece ser secreto. Tudo parece ser uma nova descoberta. Como se o criador quisesse que somente aquela parcela de seu personagem fosse exteriorizada, e outros efabuladores seriam desbravadores corajosos na descoberta daquilo que Eça não queria que fosse publicado. De fato tudo isso é conjectura lúdica, mas bem que poderia ser verdade.

Os espólios fazem com que Fradique Mendes não se esgote e que sempre haja algo a ser visto sobre este homem. Em A Correspondência já há a menção do espólio de Libuska, que será trabalhado em Vidal, com a figura do filho de Fradique - que na cena final queima os documentos do pai (cena também trabalhada em Venâncio, que reconfigura o quebra cabeça e diz ter sobrado algo). Um parece "passar a bola" ao outro, que resolve o problema, ou que problematiza mais 
criando um novo espólio - É o caso do próprio Venâncio (com o álbum de fotos e os esquemas de Fradique).

Como em Os Mistérios há somente uma aparição rápida, não há menção aos espólios, já em A Correspondência há, como dito, o espólio de Libuska. Vidal pega essa ponte e coloca em cena o espólio de Palidoff. Agualusa cria outra expectativa de um espólio deixado com Ana Olímpia, uma das mulheres do janota. E, por fim, Venâncio faz menção a todos os espólios e cria um mais excêntrico e inesperado, que faz com que os outros sejam relativizados, cria esquemas de códigos que serviam para informar a coroa portuguesa sobre investidas na África e na América. Trata-se de um espólio que faz com que o leitor volte aos outros (Lapidárias, cofre de Libuska, cartas de Ana Olímpia) e duvide se ali havia somente cartas contando suas experiências ou códigos secretos.

Como visto, Fradique Mendes é construído de maneira bastante coerente por todas as suas passagens, ou frações. Há elementos em comum e regras a serem respeitadas nessa criação. Por mais que não tenhamos trabalhado outras efabulações, acreditamos que todas elas respeitam essas coerências aqui estabelecidas - o que de fato é substrato para um próximo trabalho, trazer as outras ficções fradiquianas e também os textos de imprensa. 


\section{CONSIDERAÇÕES FINAIS}

Os estudos da personagem aqui propostos dão, parcialmente, uma ideia de que há sim coerência, no tocante à construção, à temporalidade, e às propostas de criação e recriação da personagem Fradique Mendes. Coerência essa que perpassa todas as efabulações fradiquianas. Desde o Fradique em Os Mistérios (Eça e Ramalho) até a fração fradiquiana em Esquemas de Fradique, de Fernando Venâncio.

Excêntrico já desde o início, a personagem dá substrato para apropriações. Eça se coloca em uma de suas mais marcantes personagens, seu alter ego, e depois dele, essa personagem, ou melhor, a visão engajada e sarcástica do foco fradiquiano influenciou a própria produção do autor, segundo Ana Nascimento Piedade.

Estrutura essa que depois é usada por outros, guardando suas devidas proporções: com Agualusa em um trabalho minucioso na desmitificação de África, com Vidal em uma retomada sobre a apatia portuguesa frente seus próprios costumes e mitos.

Com Venâncio, Fradique volta ao gênero romanesco e o texto, em um viés ensaístico, toma forma pelas mãos de um jornalista do século XXI, Martinho Telha, que rememora e pesquisa sobre a vida desse grande homem.

Há uma curiosa construção do próprio personagem Martinho, um jornalista que é influenciado por duas forças (pessoas): uma é a figura de uma professora universitária, que o instiga a sair das malhas da "história", onde procurava resquícios da passagem de Fradique pelo mundo, para produzir ficção, ou seja, aqui temos a condição para se recriar novamente essa personagem, estendendo ainda mais o fio da narrativa fradiquiana.

Em contraposição há quem seria um parente próximo de Fradique, que cobra informações reais sobre o tio. Essa relação sem dúvida corrobora com toda a proposta de criação da personagem no tocante ao limiar entre história e ficção. Eça cria Fradique para ser real, e falar por ele.

Também nessa malha narrativa podemos perceber que há uma preocupação temporal bastante acentuada, na maioria dos autores, principalmente em Agualusa e Venâncio. Aquele tem como base para a sua linha temporal as datas das cartas de A Correspondência e, através delas, elabora sua linha, aproveitando-se de lacunas deixadas por Eça, um vazio temporal preenchido com maestria, segundo o crítico Fernando Venâncio.

Agualusa tem como base um fio bem delineado, já que o próprio gênero epistolar determina uma linha do tempo bem delimitada. Remonta a personagem nos momentos da história do século XIX onde Eça deixou espaços. A linha do tempo em Venâncio é caracterizada de outra maneira, se em Agualusa ela parece ser um fio, em Venâncio parece ser uma malha, e ainda mais, nela parecem 
haver linhas cortadas e até mesmo nós. Cortadas quando Martinho parece não saber o limite entre a realidade e a ficção, pois no que seria realidade o fio teria um calibre, no que seria ficção mais tênue, maleável, frouxo.

Os nós se dão em momentos em que Martinho parece tentar reconstituir, a sua maneira, confusa, os fios já traçados, e uni-los, quando, por exemplo, repara que Agualusa, em certa passagem da história, deixou escapar uma das datas, pois seria impossível Fradique estar na África naquele momento, em outro quando reformula a cena em que o príncipe de Palidoff queima o espólio de Fradique, faz com que algo se salve. Linhas, nós e cortes fazem parte dessa construção a várias mãos.

Discutiu-se também a questão de que Eça extrapola a figura do Flâneur, já que para Fradique os limites de um boulevard não são o bastante. Na verdade nem mesmo os limites da Europa são o bastante. Como o próprio autor Fernando Venâncio afirma, Fradique é um homem do mundo, nele cabem franceses, portugueses, italianos, ingleses. Eça já o colocou para além das fronteiras da Europa, o colocou na Ásia por exemplo. Agualusa aproveitando a deixa o coloca na África e no Brasil.

Mas curiosamente toda a narrativa de Venâncio é elaborada dentro da fronteira portuguesa. Acreditamos que uma volta ao romance pode ser também uma volta ao Portugal de Os Mistérios, do tradicionalismo, da saudade e dos grandes mitos. Como, por exemplo, o final da obra de Venâncio, em que Martinho e o amigo deixam de observar o encontro (mítico) entre os dois parentes do homem do século para festejar o aniversário de 25 anos da revolução dos cravos, em uma festa em praça pública.

Acreditamos que há uma volta ao olhar típico português - uma reconciliação com Portugal. O olhar ensaístico de Venâncio parece recolocar essa personagem novamente na órbita portuguesa, parece dizer e afirmar que Fradique Mendes pertence ao povo português, que é tudo aquilo que os portugueses precisam ser, ou podem ser. Fradique nasce pelo gênero romanesco e a aparição com Venâncio é também pelo mesmo gênero, tendo ganhado vida nas cartas (gênero que o aproxima de figura histórica, do universo da verdade, da física) e inicialmente como dândi, viajante, excêntrico demais em Os Mistérios e em Venâncio ganha cores de ficção, de lúdico, de metafísico.

Até o momento podemos perceber que não há somente uma continuidade narrativa, como se um começasse uma história e outro simplesmente a continuasse. Há uma malha complexa de vozes, como afirma Bakhtin sobre o discurso. Há intencionalidades narrativas, há formulas e regras de construção que se fazem com extrema coerência. Todos os Fradiques são os Fradiques de Eça, tamanha coerência e coesão entre eles. Nenhum escapa ao olhar felino, ácido e direto, guardando seguramente suas devidas proporções no tocante às intencionalidades.

As regras do jogo foram dadas por Eça, e são respeitadas por cada efabulador, que se utiliza 
de seu Fradique da maneira que lhe convém. O olhar crítico de Eça, o olhar histórico de Agualusa, o olhar inconstante de Vidal e o olhar português de Venâncio montam essa trajetória de um dos mais fascinantes personagens da literatura portuguesa. 


\section{BIBLIOGRAFIA:}

AGUALUSA, José Eduardo. Nação Crioula. Rio de Janeiro, Gryphus, 2000.

ABDALA Jr., Benjamin. Ecos do Brasil: Eça de Queirós. São Paulo: Senac, 2000. \&, SCARPELLI, Marli Fantini. Portos Flutuantes: trânsitos ibero-afro-americanos. São

Paulo: Ateliê, 2004.

. De Vôos e Ilhas: Literatura e Comunitarismos. São Paulo: Ateliê, 2003.

ABREU, Márcia (org.). Trajetórias do romance. Campinas: Mercado das Letras, 2008.

ADORNO. Theodor W. Notas de literatura I. Coleção espírito crítico. Duas Cidades. Editora 34. 2006.

AGUIAR, Flávio, MEIHY, José Carlos \& VASCONCELOS, Sandra, orgs. Gêneros de fronteira. São Paulo: Xamã, 1997.

ALVES, Armando. Retratos de Eça de Queiroz. Fundação Eça de Queiroz. Porto. 2000.

AUERBACH, Erich. Mimesis. A representação da realidade na literatura ocidental. São Paulo: Perspectiva, 1976.

AVELAR, Idelber. Alegorias da derrota. Belo Horizonte: Ed. UFMG, 2003.

ARENDT, Hannah. Entre o Passado e o Futuro. São Paulo, Perspectiva, sd.

BAKHTIN, Mikail. Questões de literatura e de estética: a teoria do romance. São Paulo: Unesp, 1988.

Problemas da Poética de Dostoiévski. Rio de Janeiro, Forense Universitária,1981.

BAUDELAIRE. Charles. Flores do mal. Editora Sulina. 2008.

BARROS, Diana L. P. \& FIORIN, José Luiz (orgs.), Dialogismo, Polifonia, Intertextualidade em torno de Bakhtin. Ensaios de Cultura nº 7, São Paulo, Edusp, 1994.

BENJAMIN. Walter. Magia e técnica - Arte e política. Editora brasiliense. São Paulo. 1996. . Charles Baudelaire, um lírico no auge do capitalismo. Editora brasiliense: São Paulo, 2000.

BERRINI. Beatriz. Portugal de Eça de Queiroz. Imprensa Nacional - Casa da Moeda. 2001. . Eça e Pessoa. A regra do jogo edições. Lisboa. 1985.

BLANCHOT, Maurice. O Espaço Literário. Trad. Álvaro Cabral, Rio de Janeiro. Rocco, 1987.

BOMFIM, Manuel. A América Latina: males de origem. Rio de Janeiro: Topbooks, 1993

BOSI, Alfredo. Literatura e resistência. São Paulo: Companhia das Letras, 2002.

BRAGA, Teófilo. As modernas idéias na literatura portuguesa. Porto: Chardron, 1892. . Curso de História da Literatura Portuguesa. Lisboa: Nova Livraria Internacional, 1885. . Manual da História da Literatura Portuguesa desde as suas origens até o presente. 
Porto: Livraria Universal de Magalhães \& Moniz, 1875.

BRAIT, Beth (Org.). Bakhtin - Conceitos-chave. Editora Contexto. São Paulo. 2006.

BUESCO, Helena Carvalhão (coord.). Dicionário do romantismo literário português. Lisboa: Editorial Caminho, 1977.

CAL, Ernesto Guerra. Língua e estilo de Eça de Queiroz: Elementos Básicos. Almedina. Coimbra. 1981.

CAMÕES. Luis Vaz de. Os Lusíadas. 1. ed. São Paulo: Martin Claret. 2000.

CANDIDO. Antônio. A personagem de ficção. 11 ed. São Paulo. Perspectiva. 2005. . A educação pela noite e outros ensaios. São Paulo: Ática, 1987.

Tese $e$ antítese. Rio de Janeiro: Ouro sobre Azul, 1976. . Formação da Literatura Brasileira. Belo Horizonte: Itatiaia, 1981.

CAVALCANTI, Paulo. Eça de Queiroz: agitador no Brasil. Editora Guararapes. Recife. 1983

CHAVES, Rita. A formação do romance angolano. Coleção Via Atlântica. FBLP. 1999.

CORTESÃO, Jaime. Eça de Queiroz e a questão social. Imprensa Nacional-Casa da Moeda. Lisboa. 2001.

COUTINHO, E. F. \& CARVALHAL, T. F. (orgs.). - Literatura Comparada: Textos Fundadores. Rio de Janeiro: Rocco, 1994.

DAL FARRA, Maria Lucia. O narrador ensimesmado. São Paulo: Ática, 1978.

DUARTE, Luiz Fagundes. A fábrica dos textos: ensaios de crítica textual acerca de Eça de Queiroz. Edições Cosmos. Lisboa. 1993.

EAGLETON, Terry. The Illusions of Postmodernism, Mass. Blackwell Publishers, 1996.

FONSECA, Maria Nazareth Soares. Fradique Mendes nas rotas do Atlântico Negro. In: Os Centenários: Eça, Freyre e Nobre. FALE.UFMG. Belo Horizonte. 2001.

FONSECA, Márcio Alves. Michel Foucault e a Constituição do Sujeito. São Paulo, EDUC, 1995.

FOUCAUT. Michel. Arquiologia das Ciências e História dos Sistemas de Pensamento. Coleção ditos e escritos II. Forense Universitária. 2008. . O que é um autor?. 4. Edição. São Paulo. Editora Passagens. 2009. . "Nietzsche, Freud e Marx". Theatrum Philosoficum. São Paulo, Princípio, 1987. . A Hermenêutica do Sujeito. São Paulo, Martins Fontes, 2004.

FRANÇA, José-Augusto. O Romantismo em Portugal. Lisboa: Livros Horizonte, 1975-1977.

GAGNEBIN, Jeanne Marie. História e Narração em W. Benjamin. Editora Perspectiva: São Paulo, 1999.

GENETTE, Gerard. Parlimpsestos. Faculdade de Letras. Belo Horizonte. 2006.

GILROY, Paul. Atlântico Negro. Editora 34, 2009.

HAUSER. Arnold. História social da literatura e da arte. São Paulo: Mestre Jou, 1982. 
HUTCHEON, Linda. Poética do Pós-modernismo. Ed. Imago, 1991. Uma teoria da paródia. Edições 70. Rio de Janeiro. 1985.

JACOTO, Lílian. Da Saga à Andança Solitária. São Caetano do Sul, SP, Yêndis Editora, 2005. . "Focalização e exclusão social no neo-realismo", in: Literatura Portuguesa Aquém-

Mar (organização de Annie G. Fernandes e Paulo M.Oliveira). Campinas, Editora Komedi, 2005.

JORGE. J de Melo. Os tipos de Eça de Queiroz. Livraria Brasil. São Paulo. 1940.

LIMA, Isabel Pires de, "Traços pós-modernos na ficção portuguesa atual”, in : Semear - Revista da Cátedra Padre Antônio Vieira de Estudos Portugueses. Rio de Janeiro, 2000, nº 4, pp. 9 a 28.

LINS, Álvaro. História literária de Eça de Queiroz. Bertrand. Lisboa. 1959.

LOPONDO, Lílian (org.), Dialogia na Literatura Portuguesa. São Paulo, Scortecci, 2006.

LOURENÇO, Eduardo. Mitologia da saudade. Companhia das Letras. 1999. . A nau de Ícaro. Companhia das Letras. 2001. . Nós como Futuro, Lisboa, Assírio e Alvim, 1997.

LUZES, Pedro. Sob o manto diáfano do realismo: psicanálise de Eça de Queiroz. Ed. Fim de Século. Lisboa. 2001.

MACHADO. Roberto. Nietzsche e a verdade. Editora Graal. São Paulo. 2002. Foucault, a Filosofia e a Literatura. Rio de Janeiro, Jorge Zahar Editor, 2001, $2^{\mathrm{a}}$ ed. . Nietzsche e a Verdade. São Paulo, Paz e Terra, 1999.

MARCOS, José Antônio. O Enigma das Cartas Inéditas de Eça de Queirós. Lisboa, Cosmos, 1996. MARQUES, Gentil. Eça de Queiroz, o romance de sua vida e da sua obra. Edição Romano Torres. Lisboa. 1946.

MARQUES, Oliveira. História de Portugal. 3. ed. Lisboa: Palas Editores, 1986.

MATOS. Álvaro Costa. Conferência apresentada no âmbito do Ciclo de Colóquios: António Rodrigues Sampaio, Jornalista e Político, I Colóquio: Rodrigues Sampaio, Jornalista e Panfletário, 1. ${ }^{a}$ Comunicação (19 de Outubro de 2006, Hemeroteca Municipal de Lisboa).

MEDINA, João. Eça de Queiroz e a geração de setenta. Moraes. Lisboa. 1980. . Eça político: ensaios sobre aspectos político-ideológicos da obra de Eça de Queiroz. Seara Nova. Lisboa. 1974.

MENDES. Carlos Fradique (Antero de Quental). Versos - Textos breves. Lisboa: Edições 70. 1973. MENEZES, Djacir. Crítica social de Eça de Queiroz. Imprensa Universitária do Ceará. Fortaleza. 1962.

MENDES, João. Eça de Queiroz: tipos, estilo, moralidade. Pro Domo. Lisboa. 1945.

MIRANDA, Wander Melo, org. Narrativas da modernidade. Belo Horizonte: Autêntica, 1999. MOOG. Vianna. Eça de Queiroz e o século XIX. Edição da livraria do Globo. Porto Alegre. 1938. NUNES, Benedito. O tempo na narrativa. São Paulo: Ática, 1988. 
NUNES, Cassiano. O lusitanismo de Eça de Queiroz. CEB. Rio de Janeiro. 1947.

OLIVEIRA. Alberto de. Eça de Queiroz: páginas de memórias. Portugália Editora. Lisboa. 1945.

OLIVEIRA, José Osório de. Oliveira Martins e Eça de Queiroz. Lusitania, Lisboa. 1923.

PIEDADE, Ana Nascimento. Fradiquismo e modernidade no último Eça - 1888-1900. Imprensa

Nacional - Casa da Moeda. 2003.

PIRES, José Cardoso. Cartilha do Marialva. Moraes Editores: Lisboa, 1960.

PROENÇA, Maria Cândida. D. Manuel II: Colecção "Reis de Portugal". Lisboa: Círculo de Leitores, 2006.

QUEIROZ, Eça. Correspondência de Fradique Mendes. Porto. Lello \& Irmão. 1946. . O mistério da estrada de Sintra. Editora Arte e Letra. 2008. . Últimas páginas. Porto. Lello \& Irmão. 1938.

RAMOS, Leão. Ascensão: O Integralismo Lusitano. Edições Gama, Porto, 1943.

REIS, Antônio Simões dos. Eça de Queiroz no Brasil. Valverde. Rio de Janeiro. 1945.

RICOEUR, Paul, Tempo e Narrativa. Campinas: Papirus, 1994. 3 v.

RIEDEL, Dirce, org. Narrativa. Ficção e história. Rio de Janeiro: Imago, 1988.

ROSENFELD, Anatol. Reflexões sobre o romance moderno. In: . Texto/contexto. São Paulo: Perspectiva, 1969.

SANTOS, Boaventura de Sousa. Pela mão de Alice. Cortez Editora. 2008.

SARAIVA. Antônio José. A Tertúlia Ocidental. Ed. Gradiva. Lisboa. 1996. . As idéias de Eça de Queiroz. Centro Bibliográfico. Lisboa. 1947.

SCHWARZ, Roberto. Ao vencedor as batatas. São Paulo: Duas Cidades, 1981.

SENNETT, Richard. O Declínio do Homem Público. Companhia das Letras, 1988.

SERRÃO, Joel. O Primeiro Fradique. Lisboa. Horizontes. 1985.

SIMÕES, João Gaspar. Perspectiva Histórica da Ficção Portuguesa. Lisboa: Publicações Dom Quixote, 1987.

VENÂNCIO, Fernando. Os Esquemas de Fradique. Lisboa, Grifo, 1999. . Objetos achados. Caixotim Edições. Porto. 2002.

WATT, Ian. Mitos do Individualismo Moderno. Jorge Zahar, 1997. . A ascensão do romance. Companhia de Bolso. 2010.

Revistas:

ECLÉTICA. Puc-Rio. Julho e dezembro de 2003. <http://puc-riodigital.com.pucrio.br/media/2\%20-\%20o\%20novo\%20fl\%C3\%A2neur.pdf > visitado em 27 de junho de 2011.

Revista ContraPonto, Belo Horizonte, $\quad$ v. $1, \quad$ n. 1. <http://periodicos.pucminas.br/index.php/contraponto $>$ p. 13-24, jul.2011. Visitado em 23 de agosto de 2011. 
Suplementos:

<Suplemento ao Dicionário de Eça de Queiroz. Caminho. Lisboa. 2000> 
ANEXO 
Entrevista com FERNANDO VENÂNCIO

No Rossio, Café Suíça, uma viagem no tempo na companhia de Fradique Mendes

Por Eduardo Gonzales Moreira

Eduardo Gonzales Moreira é aluno do Programa de Estudos Comparados de Literaturas de Língua Portuguesa do Departamento de Letras Clássicas e Vernáculas da Faculdade de Filosofia, Letras e Ciências Humanas da Universidade de São Paulo. É professor da rede particular de ensino na Cidade de São Paulo, escritor: publicou em 2009 o livro O Jornalista, pela Linear B. www.edumoreiraarte.blogspot.com

Fernando Venâncio é um escritor português e crítico literário. Atualmente, trabalha na Universidade de Amsterdã e tem nacionalidade holandesa. É autor e colaborador regular de revistas portuguesas de prestígio como Jornal de Letras, Ler e Colóquio/Letras, trabalha como crítico literário. Ele também publica no jornal Expresso e na revista Visão. Até março de 2008, foi colaborador regular do blog coletivo “Aspirina B".

Em um dia nublado, 11 de janeiro de 2011, terça-feira, após conhecer a cidade branca, tive a feliz oportunidade de entrevistar o autor da obra Os Esquemas de Fradique, o prof. Dr. Fernando Venâncio. Marcamos às 16 horas em um dos cafés mais tradicionais da cidade, o Café Suíça, situado no Rossio, área central de Lisboa.

Eduardo Moreira: Carlos Fradique Mendes é, sem dúvida, uma das personagens mais enigmáticas da literatura portuguesa, ou posso dizer da literatura mundial, um misto de homem, gênio, pecador. $O$ senhor poderia citar algumas poucas características legitimamente portuguesas que essa personagem carrega, e se carrega?

Fernando Venâncio: Creio que uma das graças de Fradique é que exatamente tem muito pouco da figura do português. É alguém que acumula durante a sua vida várias existências, sendo impossível que pudesse fisicamente fazer tudo o que ele fez. Nem viveu muito, morreu com cinquenta e poucos anos. E, no entanto, ele teria visitado praticamente tudo no mundo, menos a África austral e o Brasil, onde o romancista José Eduardo Agualusa o leva, no romance Nação Crioula. Nesse sentido, o Agualusa ainda junta a impossibilidade que o Eça descreve com outra impossibilidade. Fradique contactou com toda a gente importante que havia no mundo, leu tudo o que havia de importante pra ler, o que é muito, aprendeu uma porção de idiomas, e ainda tinha tempo para a sua existência de dândi, com as suas aventuras, com seus esportes. Nesse sentido, ele poderia no 
máximo ser um inglês com umas tintas francesas, tintas de italiano, mas português muito pouco. Eu não tenho a certeza do que vou dizer, mas podíamos suspeitar que o Eça fez dele alguém que exatamente não poderia ser português. E, no entanto, era português. Honra-nos muito. Fradique seria o melhor de nós. O melhor no sentido neutro, portanto, a melhor parte de nós, e também o melhor indivíduo português pensável. E talvez essa não só impossibilidade de ele existir como pessoa, mas também a sua não portugalidade, talvez tudo isso faça parte do jogo mental que o Fradique é. Sim, é um jogo mental do Eça. Há quem entre pela simbologia e diga que é uma espécie de compensação do Eça, que sempre teria tido um complexo de inferioridade, ao ser um filho ilegítimo. Não é necessário entrar por aí. A genial construção daquela figura já enche todas as medidas.

\section{E. M.: O senhor acredita que o fato desta personagem ter sido criada tendo como forma o gênero epistolar, isso deu margem para as efabulações? Ou seja, o senhor acredita que o caráter lacunar temporal da carta pode ter também promovido isso?}

F. V.: Creio que você tem uma intuição formidável ao fazer a ligação entre o caráter lacunar da carta e a figura de Fradique Mendes. Acho que nunca ninguém fez essa conexão. Meus parabéns! Digamos que escrever em cartas é talvez a maneira mais fácil de fazer ficção. É uma impressão muito forte que tenho, e tenho-a há muito tempo. Se alguém não soubesse como escrever um romance, nós poderíamos dar-lhe o conselho: "Escreve cartas. E faça por essas cartas o romance”. A carta presta-se muito à efabulação. Isso é uma convicção muito forte minha, só que não sei racionalizar a questão. Mas é mais fácil pra efabular inventando uma carta do que inventando um episódio. A sua intuição é também valiosa no sentido da própria figura do Fradique, de que nunca se poderia dar uma ideia genérica e atender por completo. Claro que o prefácio que o Eça escreveu sobre Fradique Mendes, que é um autêntico romance, que ele chama Notas e Comentários, que é a vida de Fradique Mendes, isso é uma biografia, simplesmente é uma biografia dos contatos entre eles. Porque naquilo que o Fradique fez, naquilo que ele viajou, naquilo que ele empreendeu, o Eça é muito sucinto, dá exemplos picantes, exemplos que falam à imaginação, mas não aprofunda, ele não investe em uma viagem concreta, numa iniciativa concreta. A única viagem que eu recordo que é contada com pormenores nessa «Introdução» de A Correspondência de Fradique Mendes, é a viagem ao Oriente, que o próprio Eça fez. Portanto, quando Eça e Fradique contactam, Eça esteve nessa informação, nos episódios. Quanto à própria biografia do Fradique, só Fradique, nós só sabemos em traços largos: fez viagens, contactou com muitas pessoas, não foi ao Brasil, não foi à África Austral e, portanto, há imensas lacunas na biografia de Fradique Mendes, só Fradique Mendes. E, portanto, o gênero epistolar se enquadra muito bem com essas lacunas, mais uma vez a sua intuição. Exatamente esse tipo de vida pouco preenchida permite a continuação da ficção. E 
repare que a ficção já começa muito cedo. Poucos anos depois da morte do Eça, em 1900, aparece já a primeira ficção sobre Fradique. Faço referência a ela num livro chamado Objetos Achados, onde está um capítulo sobre a ficção sobre Fradique Mendes. E aí indico a primeira, feita por João Chagas, que em 1908 escreve uma carta ao filho de Fradique Mendes. É a primeira ficção pósqueirosiana.

E. M.: Um discurso em camadas, acredito que há até se chegar ao último Fradique. Um personagem que é formado pelos discursos de vários autores. O senhor acredita que há uma coerência no processo de formação dessa personagem no decorrer do tempo?

F. V.:- Tenho impressão que sim. Não sei se por casualidade ou por uma razão intrínseca da figura. Se há alguma coisa em comum entre todas essas ficções, é realmente o fascínio que a figura recolhe, concita, estimula, cria. Algumas ficções são melhores do que outras. Por exemplo, a ficção daquele livro, O único filho de Fradique Mendes, é relativamente fraca. Mas foi construída por um rapaz aos 16 anos, e nessa idade as capacidades de efabulação não são as mais fortes. Isso pra dizer que há muitas diferenças na efabulação da figura de Fradique. Isso cria diversidade, talvez isso também possa ser uma vantagem, não sei. Mas o que há é sempre esse gosto imenso de pegar nessa figura e continuar a dar-lhe vidas. O Fradique de Agualusa tem um lado biográfico, digamos. Dá a ele um determinado tipo de existência. Mas as outras histórias acontecem já depois da "morte" de Fradique. E mesmo o meu romance só tem Fradique ao princípio, como acompanhante da princesa Rattazzi que vem visitar Portugal, um fato real, o que é ficção é Fradique a acompanhar a princesa. Digamos que há o Fradique ainda vivo, e há o Fradique que já não vive histórias da sua existência. No primeiro caso, do filho, no segundo caso do Agualusa, uma filha, e no meu caso um neto e uma neta.

E. M.: Especificamente o Fradique de Agualusa, a meu ver, é tomado de empréstimo com o objetivo de transgredir o Fradique queirosiano, mostrando uma outra face de este ser. A meu ver ao mesmo tempo em que transgride, homenageia e até mesmo fortalece o Fradique queirosiano, pois somente essa personagem poderia ter força, coragem e excentricidade o suficientes para se aventurar na Europa, na África e no Brasil. O que o senhor pensa sobre isso?

F. V.: A sua pergunta é perfeita. E eu não poderia responder melhor do que repetir o que você disse. Acho que você tem também uma intuição magnífica e que só ganha em desenvolvê-la.

E. M.: O senhor acredita, assim como eu, que o mote Fradique Mendes é inesgotável? Também por se tratar, de certa maneira, de um personagem moderno e principalmente 


\section{mutável?}

F. V.: Estou totalmente de acordo. Eça construiu de maneira que ele é inesgotável. Temos um ponto de vista positivo e um ponto de vista negativo. Do ponto de vista negativo digamos que Eça não o descreveu totalmente, deixou muita margem à imaginação e à imaginação posterior, mas também do ponto de vista positivo no sentido de que ele foi criado sobre uma fórmula inesgotável. Ele é construído pra ser inesgotável, pra reunir realmente toda a humanidade, toda a possibilidade do homem culto da segunda parte do século XIX. Ele é uma espécie de enciclopédia, tanto naquilo que faz como naquilo que conhece. Realmente tudo o que fez é importante. Ele contactou com pessoas importantes, ele reúne toda a humanidade, toda a sede da humanidade em potência, e nesse sentido o molde de que ele foi feito, a fórmula "Fradique Mendes", é inesgotável.

\section{E. M.: O livro do senhor, Os Esquemas de Fradique, e o livro de José Antônio Marcos, $O$} Enigma das cartas inéditas de Eça de Queiroz, colocam a todo o momento a questão entre a tênue fronteira entre realidade e ficção. Essa argumentação faz com que a história de Fradique fique mais provocante?

F. V.: Essa mistura de realidade e ficção é muito convidativa, na verdade é a fórmula da ciência e ficção, ou ficção-científica. Há sempre uma componente atual, portanto, reconhecível, e há uma componente irreal, que é imaginária. Se uma ficção científica fosse só, só imaginária, não funcionaria. Descrever uma guerra mundial de robôs é pensável, mas não é a melhor ficçãocientífica. Ora, o Eça, ao construir a figura de Fradique Mendes, ele está a fazer essa mistura que nós diríamos até que tem uma parte ou espécie de atualidade, porque se há coisa que pode dizer-se sobre essa fusão entre realidade de ficção é que é muito pós-moderna. Nesse sentido, tudo o que fez imaginar uma realidade paralela, como é o caso de Fradique Mendes, ele é uma realidade paralela, e não somente ficção, ele não é uma figura de ficção, é uma figura de "realidade paralela", porque é um confidente, um amigo, de alguém real, do próprio autor que descreve a história. Portanto, Eça cria uma espécie de biografia paralela à sua, e isso é muito, muito pós-moderno. Uma das características do pós-modernismo é tornar indestrinçável, em uma narrativa, a realidade e a ficção. Eça cria uma literatura que está a cem anos de distância, e, no nosso tempo, ainda muito viva e muito explorada até nos romances históricos, que são históricos porque as circunstâncias são reais, mas em que há uma personagem de ficção. É também uma fórmula formidável e é diante dessa fórmula que o Fradique é construído. Diretamente uma pessoa de realidade, uma realidade absolutamente tangível, mas ele de fato não existe.

E. M.: Há algo em comum para o senhor entre "as grandes navegações", “o sebastianismo" e 


\section{Fradique Mendes?}

F.V.: Essa é muito boa. Digamos que são três grandes invenções portuguesas. E pelo visto os portugueses têm muita capacidade de imaginar. As descobertas foram imaginadas antes de serem realidade, e elas foram acompanhadas de bastante ficção, ou ao invés de dizer ficção podemos dizer narrativa, e há ótimas narrativas das descobertas, por exemplo, a História trágico-marítima e Os Lusíadas, isso está entre 1500 e 1572. Digamos que as descobertas portuguesas já foram acompanhadas de narrativas. O sebastianismo é também uma narrativa ideológica, que os portugueses dos séculos XVI e XVII contam a si próprios pra se aguentarem nas adversidades, e no fundo pra não se frustrarem, pra conservarem até um pouco de positividade de sua auto-imagem. "Nós estamos em uma situação tremenda, sem nobreza, sem dinheiro, sem rei, mas Sebastião vai voltar". O Fradique é também uma narrativa ideológica. Digamos que há uma mensagem subliminar do Eça que é: "Nós, portugueses, somos uma desgraça, péssimos numa porção de coisas. Mas imaginemos que nós éramos um Fradique". Fradique recolhe, portanto, tudo aquilo que os portugueses deveriam ser, deveriam poder ser e não são. Eu estou a dizer isso e estou a pensar em outra coisa que tem também um pouco a ver com o Eça. Trata-se de um amigo dele, o Ramalho Ortigão. O livro mais famoso dele, A Holanda, é uma história, uma descrição de viagem de Ramalho à Holanda por ocasião de uma Exposição Universal. Mas toda a clara intencionalidade do livro é descrever a Holanda como um espelho pra Portugal: "Vejam o que esse país faz, o que esse país consegue". É uma visão de direita, uma visão conservadora, Ramalho era realmente uma figura de direita, de uma direita imensamente educada, muito consciente e orgulhosa de si. O país era nesse tempo, nesses anos 80, 90, um caos. E então Ramalho apresenta a Holanda, apresenta a ordem que existia na Holanda, o desenvolvimento que existia na Holanda. Tudo isso é uma mensagem: “Meus caros compatriotas, vejam, esse país existe. Esse país é possível aqui." Nesse sentido, há o autêntico paralelo entre A Holanda do Ramalho e o Fradique Mendes do Eça. Ambas são narrativas ideológicas, com uma intencionalidade civilizadora, educacional muito clara. Penso que talvez nunca ninguém tenha feito esse paralelo.

\section{E. M.: Ao meu ver, Fradique nasce contestador e destemido, depois toma ares de garoto propaganda e de personagem muitas vezes sentimental com Agualusa. O seu Fradique, mesmo que ele seja retomado pela lembrança das personagens no romance, o que é o seu Fradique? Como o senhor definiria a imagem dessa personagem em sua obra, mesmo que o senhor não a tenha criado fisicamente?}

F. V.: É um fato: eu não criei o Fradique. O "meu" Fradique tem alguma elaboração pósqueirosiana, mas aproveito o mais possível o Fradique já criado pelo Eça. Portanto, não tenho qualquer intencionalidade de explorar a figura do Fradique, porque já havia a exploração 
queirosiana, e já havia a exploração agualusiana, e essas são duas criações magníficas. Não senti qualquer necessidade de imitá-los nesse sentido. Eu tinha toda uma história atual pra contar, mas tinha alguma necessidade, também, de fazer um trabalho de ensaio. Há uma componente de ensaio no meu romance, eu reconheço isso, e isso torna um romance difícil de ler. Vamos dizer, é para os bons provadores. Isso faz com que o romance nunca poderia ser um best-seller. É uma espécie de curiosidade literária. Está muito construído na base de referências literárias, a primeira é logo a figura de Fradique, depois há referências aos meus antecessores, a todos os meus antecessores, com uma porção de interferências de segunda ordem, que não são dos meus antecessores, que são criação minha. Outro elemento meu são os tais "esquemas", uma espécie de diário que ele teria escrito, e isso é realmente invenção, mas também uma maneira de dar interesse ao romance, mais do que só as aventuras dessas quatro ou cinco personagens principais, o neto e a neta, depois há o “eu”, e há um amigo dele, aquele Baltazar Touriga, depois há uma personagem próxima ao protagonista que é uma amiga que ele tem pelo ponto de vista profissional e há depois a namorada, são duas figuras bastante apagadas. Portanto, eu inventei essa história dos "esquemas", umas indicações mais ou menos técnicas que o Fradique tinha, e que poderiam servir de base para uma autobiografia sua. Digamos que o meu Fradique é demasiado complexo para o leitor comum. Nunca poderia ser um romance popular, e nem foi essa propriamente minha intencionalidade. Foi mais uma espécie de prolongar o jogo, um jogo magnífico, um jogo fascinante. Tive sempre muito apoio do meu jovem editor, Manuel Vieira da Cruz, que foi sempre um grande fã do meu Fradique, desde o começo do livro, desde o absoluto começo do livro, porque foi ele que me desafiou pra escrever um romance com o Fradique como objeto. É realmente uma pessoa muito competente no ramo de edição.

E. M.: Agora uma pergunta específica sobre o romance: No final do seu texto, deu-me a impressão de que Martinho e o colega, ao invés de entrar na sala e incomodar os descendentes de Fradique, vão andar pela cidade. Pois bem, a minha impressão foi que era uma data de festa civil, mais especificamente uma comemoração de 25 de abril. Isso realmente acontece?

F. V.: Isso acontece. Trata-se do dia 25 de abril de 1999, no momento em que se comemora o $25^{\circ}$ aniversário da revolução de abril. Mas se vir a data que está no fim do romance, a data é de março. Portanto, há uma impossibilidade metafísica, digamos, de ele descrever aquela noite antes de ela acontecer. Houve, de fato, na noite de 24 pra 25 de abril de 1999 uma grande festa na Praça do Comércio, ou Terreiro do Paço, e juntou-se lá uma imensa multidão pra ver fogos de artifício. E os dois, o protagonista e o Balto, avançam a pé, desde muito longe, com muita gente que se dirigia para essa grande concentração na Praça do Comércio. É uma espécie de apoteose, eu quis terminar o romance numa apoteose "real". Entretanto, na avenida Gago Coutinho, a avenida que vai 
para o aeroporto, no outro extremo da cidade, dá-se o encontro entre dois fantasmas, o neto e a neta de Fradique. E é exatamente porque são fantasmas que os menos fantasmas, o protagonista e o Balto, não entram em contato com eles e os deixam em sua irrealidade. É um jogo narrativo onde há todo esse relacionamento complexo entre realidade e ficção. Tudo é ficção. Mas alguma é menos "irreal" do que a outra. 